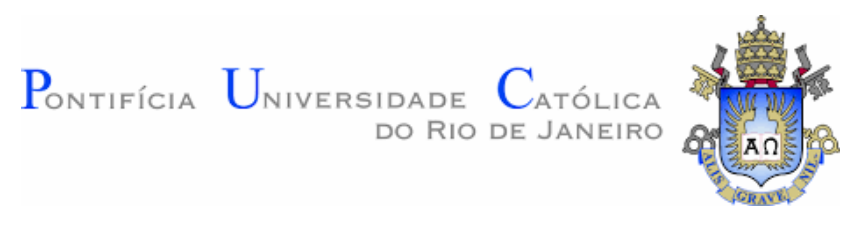

Janara Morena da Silva de Oliveira

A relação ensino e indústria: uma visão a partir da moda praia carioca

Tese de Doutorado

Orientadora: Profa. Luiza Novaes

Tese apresentada ao Programa de Pós-graduação em Design da PUC-Rio como requisito parcial para obtenção do grau de Doutor em Design.

Rio de Janeiro

Abril de 2019 


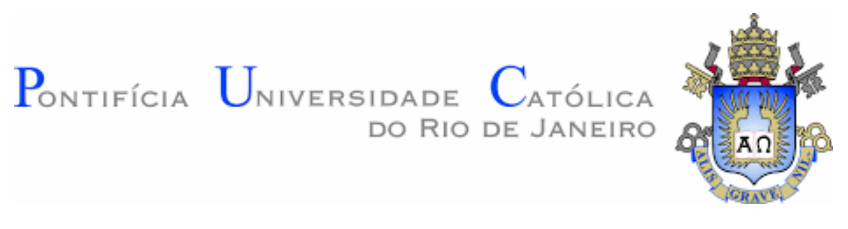

Janara Morena da Silva de Oliveira

\title{
A RELAÇÃO ENSINO E INDÚSTRIA: UMA VISÃO A PARTIR DA MODA PRAIA CARIOCA
}

Tese apresentada como requisito parcial para a obtenção do grau de Doutor pelo Programa de Pós-graduação em Design do Departamento de Artes \& Design da PUC-Rio. Aprovada pela comissão Examinadora abaixo assinada.

\author{
Profa. Luiza Novaes \\ Orientadora \\ Departamento de Artes \& Design - PUC-Rio \\ Profa. Roberta Portas Gonçalves Rodrigues \\ Departamento de Artes \& Design - PUC-Rio \\ Prof. André Lacombe Penna Rocha \\ Departamento de Administração, IAG, PUC-Rio \\ Profa. Fernanda Coutinho Ribeiro \\ Prof. Lucas da Rosa \\ Universidade do Estado de Santa Catarina - UDESC
}

Rio de Janeiro, 12 de abril de 2019 
Todos os direitos reservados. É proibida a reprodução total ou parcial do trabalho sem autorização da universidade, da autora e do orientador.

\section{Janara Morena da Silva de Oliveira}

Graduou-se em Moda e Figurino pela Universidade Estácio de Sá em 2007. Possui Pós-Graduação em Marketing pela Universidade Cândido Mendes (2010). Cursou o Mestrado Acadêmico no Departamento de Artes \& Design pela PUC-Rio. Ganhadora do prêmio promovido pelo Instituto Gênesis "Meu Futuro Negócio", desenvolveu projetos na área de moda, tecnologia, sustentabilidade, educação e artes. É pesquisadora do Bikini Art Museum (Alemanha). Atua como curadora de projetos e consultorias na Indústria Criativa. É designer de moda e empreendedora no segmento de moda praia.

Ficha Catalográfica

Oliveira, Janara Morena da Silva de

A relação ensino e indústria: uma visão a partir da moda praia carioca / Janara Morena da Silva de Oliveira ; orientadora: Luiza Novaes. - 2019.

214 f. ; $30 \mathrm{~cm}$

Tese (doutorado)-Pontifícia Universidade Católica do Rio de Janeiro, Departamento de Artes e Design, 2019.

Inclui bibliografia

1. Artes e Design - Teses. 2. Ensino de moda. 3. Indústria da moda. 4. Design de moda. 5. Moda praia. 6. Biquíni. I. Novaes, Luiza. II. Pontifícia Universidade Católica do Rio de Janeiro. Departamento de Artes e Design. III. Título.

CDD: 700 
Dedico à minha família, em especial minha avó Solange e ao meu "pai-drinho" Sérgio. 


\section{Agradecimentos}

Ao CNPq pelo auxílio concedido, sem o qual este trabalho não poderia ser realizado.

Enorme gratidão à Pontifícia Universidade Católica do Rio de Janeiro pelos incentivos em forma de uma grande rede de apoio oferecida durante as diversas etapas da pesquisa.

Ao Departamento de Artes \& Design da PUC-Rio que conta com funcionários sempre disponíveis e atenciosos.

À minha orientadora, Luísa Novaes e aos professores que participaram da banca examinadora.

Aos professores do Departamento de Artes \& Design e dos Departamentos de História, Administração (IAG) e de Comunicação. Também agradeço aos professores dos laboratórios NEXT (Núcleo experimental tridimensional), LGD (Laboratório de Gestão em Design) e do grupo Barthes, além dos funcionários e professores do Instituto Gênesis.

À professora Gilda Chataignier, pioneira "a pensar" a moda no Brasil. Obrigada pelos incentivos: "você tem o olho".

Às três mães: Dânia Maria, Wanda Mara e Berenice pelos incentivos e apoio.

Dedico ao Bauman e à Miumiu, meus leais companheiros felinos. 


\section{Resumo}

Oliveira, Janara Morena da Silva de; Novaes, Luiza. A relação ensino e indústria: uma visão a partir da moda praia carioca. Rio de Janeiro, 2019. 214p. Tese de Doutorado - Departamento de Artes \& Design, Pontifícia Universidade Católica do Rio de Janeiro.

Esta tese tem como tema a relação entre o ensino e a indústria de moda, no Brasil. Parte do pressuposto que existe uma distância entre eles impactando o setor da moda brasileira como um todo. O trabalho se apresenta como um desdobramento da dissertação de mestrado cujo enfoque se dava sobre a moda praia no contexto das relações entre design e corpo, na cultura de praia carioca. Na tese, o recorte no segmento de moda praia é mantido, mas o estudo se volta para o âmbito do ensino de moda. A moda praia é considerada um exemplo de sucesso da indústria nacional, por seu diferencial em termos de qualidade e design atrelados à cultura local. Verificou-se, entretanto, que o conhecimento relacionado à moda praia brasileira, embora ela seja reconhecida internacionalmente como referência, se encontra fragmentado e disperso. Há dificuldade na busca por profissionais bem preparados para este segmento, evidenciando a distância entre a sala de aula e o "chão de fábrica". Uma distância que tem impactado o fortalecimento da percepção de valor conquistada nas últimas décadas em diversos aspectos para o setor da moda brasileira. Para entender como ocorrem as articulações entre o ensino e a indústria, buscou-se ouvir os atores envolvidos representantes da indústria, do ensino de moda, designers, estudantes e empresários - a fim de propor, a partir da pesquisa de campo e de experimentos, recomendações para a elaboração de iniciativas estratégicas, utilizando processos de design, que aproximem a indústria e o ensino, impulsionando o setor e consequentemente o mercado de trabalho.

\section{Palavras-chave}

Ensino de moda; Indústria da moda; Design de moda; Moda praia, biquíni. 


\section{Abstract}

Oliveira, Janara Morena da Silva de; Novaes, Luiza. (Adivisor). The relationship between teaching and the industry: a view from the carioca beachwear. Rio de Janeiro, 2019. 214p. Tese de Doutorado - Departamento de Artes \& Design, Pontifícia Universidade Católica do Rio de Janeiro.

This thesis aims to deepen understanding about the relationship between teaching and the fashion industry in Brazil. It begins with the assumption that it does exist a gap in between both that consequently impact negatively in the whole sector. This theses presents itself as a deployment of a master degree dissertation, in which the focus was on the beach fashion in the context of the relations between design and body, in the Carioca beach culture. The standards of beachwear design is maintained, but the study turns to the scope of fashion learning processes. The beachwear segment is considered a successful case study for the national industry mainly for its innovation in design, quality blended with the local beach culture. Even though it is rooted as a strong reference both nationally and internationally, it has been found that the knowledge and intelectual content it is still well fragmented. There are several issues finding skilled professionals, showcasing the distance still to be narrowed between the classroom and to become hands-on in the "factory floor" and production. This gap has not contributed to the strength of the added value perception that the segment acquired in the last decades. In order to understand how the articulations between teaching and industry occur, we sought to listen to the actors involved: representatives of industry, fashion teachers, designers, students and entrepreneurs. The goal is to propose field researches and experiments, recommendations to prepare strategy initiatives utilizing design processes that could have real impact to shorten the relations of the learning centers and the market, creating incentives to accelerate the sector and ultimately contributing to the skilled job market.

\section{Keywords}

Fashion learning; Fashion industry; Fashion Design; Beachwear, bikini. 


\section{Sumário}

1 Introdução 15

1.1 Trajetórias e caminhos, do sentimento à razão 15

1.2 Escolhas metodológicas 21

1.3 Definir para dialogar: termos e conceitos 27

1.4 Cultura e mercado: dados sobre o cenário da moda praia no Brasil 32

2 A construção da reputação da moda praia brasileira em suas extensões culturais, históricas e econômicas

2.1 Apresentação do capítulo

2.2 A formação da cultura de praia no Rio de Janeiro: do banho de mar terapêutico ao banho recreativo

2.3 A formação do mercado de moda praia: o surgimento das primeiras marcas

2.4 A hegemonia dos modelos de corpos de referência para indústria de moda: norma técnica, normatização, antinorma e/ou resistência

3 A relação entre o ensino e a indústria de moda na visão de professores e alunos

3.1 Apresentação do capítulo

3.2 Design de moda, interdisciplinaridade e o contexto da educação

3.3 A voz dos representantes do ensino sobre a relação com a indústria no caso da moda praia

3.4 O ensino de moda na visão dos alunos

3.5 A experiência como curriculista de cursos de moda com abrangência nacional

3.6 A percepção sobre o ensino de moda praia segundo alunos de graduação em design de moda da PUC Rio

4 A relação entre o ensino e a indústria na visão de representantes da indústria

4.1 Apresentação do capítulo 
4.2 A voz de representantes do "apoio a Indústria e à educação profissional" do Rio de Janeiro, via "Sistema S"

4.3 A voz de designers brasileiros que atuam no mercado e na educação de moda

4.4 A voz de profissionais do setor da moda do segmento de moda praia do Rio de Janeiro

4.5 A voz de representantes da Indústria da moda

4.6 Representantes da indústria da moda falam do ensino oferecido no Brasil

4.7 A relação ensino e indústria: uma visão a partir das impressões durante a participação do Comitê Técnico Setorial

5 Projeto piloto integrador entre ensino e indústria

5.1 Apresentação do capítulo 159

5.2 Experimento 1: alunos, professores e a empresa 160

5.3 Projeto experimental espaço híbrido: ensino, criação e produção

6 Considerações finais e proposta de desdobramentos futuros

6.1 Apresentação do capítulo

6.2 Uma visão panorâmica sobre as relações ensino e indústria

6.3 O designer como conciliador entre cultura e mercado para um design como diferencial competitivo

6.4 Sugestões futuras

6.5 Experimentos compartilhados 


\section{Lista de figuras}

Figura 1 Imagem do arquivo pessoal da pesquisadora. Fotógrafo Enzo Gostolli, desfile realizado no Hotel Novo Mundo em 2011. Janara Morenna (no meio, à esquerda) e Fabíola Key com as modelos desfilando a moda praia do Projeto Amendoeiras

Figura 2 Elaborada pela pesquisadora entre 2012 e 2014 para dissertação intitulada "Relações entre o design de biquíni e o "corpo remodelado" na moda-praia carioca

Figura 3

Figura 3: A senhora Vreeland choca com sua contemporaneidade, quando em maio de 1947, lança na Harper's Bazaar a fotografia feita por Toni Frissell de uma modelo usando um biquíni de bolinha.

Figura 4

Imagem retirada do endereço https://blogaquareladobrasil.wordpress.com/ilustradores/cl assicos/alceu-penna/ acesso em 17 de janeiro de 2019

Figura 5 Retirada (print) do Instagram "Workshop com profissionais referência no mercado: é a chance de dar aquele "boost" na sua marca e fazer networking.

Figura 6 Imagens do trabalho realizado em Brasília em diversos momentos das tapas do projeto de desenho de currículo dos cursos de design de moda e técnicos, SENAI Nacional.

Figura 7 Etapas do funcionamento de uma indústria da moda praia.

Figura 8 Indústria de moda praia funcionando com setores 
interligados

Figura 9 Apresentação da metodologia do CTS para os representantes do ensino

Figura 10 Imagem dos representantes da indústria reunidos no comitê para discutir a educação

Figura 11 Imagem da peça de comunicação

Figura 12 Imagem da peça de divulgação das etapas do projeto

Figura 13 Acervo próprio da pesquisadora com alunos de moda

Figura 14 Imagens de diversas etapas do projeto na indústria e em sala de aula.

Figura 15 Imagem de parte do processo para criação da identidade visual fruto de um trabalho interdisciplinar

Figura 16 Gráfico das marcas de moda praia encontradas e sugeridas pelo Instagram durante um período de 40 meses de uso da conta @doc.bikini (nome fantasia que pode vir a mudar) a partir de 2015.

Figura 17 Moda praia, conhecimento pulverizado

Figura 18 Conhecimento sobre a moda praia foco na integração dos saberes

Figura 19 Núcleo da moda praia com foco na promoção e propagação dos conhecimento da moda praia nacional

Figura 20 Certificado de aprovação realização do projeto que envolvia exposição, publicação e multimídia. Fonte: Lab Museu do biquíni carioca" acesso em 17 de março de 2019

Figura 21 Processo de design, croqui, modelagem, costura, protótipo e prova.

Figura 22 Etapa do projeto com produção de moda e comparação entre desenho de moda e a peça pronta.

Figura 23 Referência das escamas dos peixes que ao mesmo tempo confere flexibilidade, adaptabilidade, mobilidade e força

Figura 24 Modelo de maiô engana mamãe feito com escamas estilo peixe. Sugestão de materiais em impressão 3DP para 
escamas e malha a partir do cultivo de bactéria. Pode

adicionar pigmento de Glow in the Dark ou gerar energia com mini placas solares para mudança de cores na própria peça

Figura 25 Perspectiva de formas que podem ser geradas a partir de fibras ópticas, eletroluminescência, bio tecido (bactérias) etc. O modelo maiô engana mamãe tem a mesma base/formato

Figura 26 Perspectiva de mudança de estampas e percepção de volume no mesmo modelo. $O$ escuro com aplicação de eletrônicos (wearable).

Figura 27 Foto acervo pessoal. Solange Villela na praia de Copacabana em 1947.

\section{QUADROS}

Quadro 1 Quadro 1: Fonte E-mec / IES, Graduação no Brasil, 2016

Quadro 2 Tabela de valores dos cursos por hora/aula específicos de moda praia no Brasil/ Rio de Janeiro.

Quadro 3 Ranking do Censo com dimensionamento demográfico por região.

Quadro 4 tabela FGV (2011) sobre a indústria da moda carioca 


\section{LISTA DE SIGLAS E ABREVIATURAS}

ABIT

ABRAVEST

APEX

CAD

CAM

FIRJAN

MDIC

P\&D

PDP

PEIEx

PIB

PME

PROEX

SEBRAE

SINDITEXTIL

IAG

NEXT

LGD

Associação Brasileira da Indústria Têxtil e de Confecção

Associação Brasileira do Vestuário

Agência de Promoção de Exportações

Computer-aided Design

Computer-aided Manufacturing

Federação das Indústrias do Rio de Janeiro

Ministério do Desenvolvimento, Indústria e Comércio

Exterior

Pesquisa e Desenvolvimento

Política de Desenvolvimento Produtivo

Projeto de Extensão Industrial Exportadora

Produto Interno Bruto

Pequena e Média Empresa

Programa de Financiamento à Exportação

Serviço Brasileiro de Apoio às Micro e Pequenas Empresas

Sindicatos da Indústria Têxtil

Escola de Negócios da PUC-Rio

Núcleo de Experimentação Tridimensional

Laboratório de Gestão em Design 
Todo o nosso conhecimento se inicia com sentimentos. Leonardo da Vinci 


\title{
1 \\ INTRODUÇÃO
}

\section{1}

\section{Trajetórias e caminhos, do sentimento à razão}

\author{
Conhecer e pensar não é chegar a uma verdade absolutamente certa, mas dialogar com a \\ incerteza. Edgar Morin
}

Inicio esta tese compartilhando parte da minha trajetória até aqui, para que o leitor saiba de onde vem a inquietação que me levou a trazer para o âmbito da pesquisa muitas das perguntas, reflexões e, sobretudo, meu inconformismo com as dificuldades para conseguir informações sobre ensino e mercado de moda no Brasil, que vivenciei tanto como aluna quanto como professora. Sendo assim, me coloco, na primeira pessoa do singular.

Entrei para o "universo da moda" sem planejar. Antes mesmo de iniciar uma faculdade, eu sonhava em ser atriz. Foi por ter que encontrar uma maneira de conseguir recursos financeiros para realizar meus cursos de interpretação, que lancei mão de algumas aptidões, como a do desenho, que desenvolvi logo cedo na Escola de Artes Visuais do Parque Lage (EAV) e uma outra aptidão, para a costura, desenvolvida por influência de minha avó, profissional de alta costura e aprendiz do "príncipe da moda", meu bisavô alfaiate.

Em 1999 participei do Mercado Mundo Mix, um reconhecido evento de moda itinerante com propósito de promover novos talentos. Na época, com meus 17 anos, eu fazia pinturas que viravam bolsas e acessórios. Apesar de desenhar, pensar nos processos, materiais, mix de produtos, produção/confecção e demais atividades que 
compõem do repertório de um designer de moda, eu não me considerava uma designer, artista ou uma estilista. Para que eu me sentisse legitimada enquanto profissional, era preciso ter feito um Curso Superior seguindo a popular premissa de que só assim eu me tornaria "alguém na vida".

No ano seguinte, em 2000, terminei o curso de teatro, obtive um registro de atriz e saí do Rio de Janeiro para morar em São Paulo, onde tive êxito com meus produtos. A experiência autodidata em menos de um ano se tornou um negócio ${ }^{1}$ e junto com um sócio começamos a planejar sua expansão. Arriscamos diversificar ${ }^{2}$ o público para além dos eventos de moda em diversas capitais brasileiras e abrimos stands dentro de shopping centers na Avenida Paulista, no Pátio Higienópolis e no Shopping D.

No ano de 2002, decidi voltar para o Rio de Janeiro, abrindo mão de estudar na Universidade Paulista - Unip, pois não me sentia adaptada à capital paulista. Fui da primeira turma de Moda na Universidade Estácio de Sá, em Ipanema. Na época, muitos dos meus professores diziam não possuir experiência nem com chão de fábrica ${ }^{3}$ e nem com o mercado.

Estudar Moda ${ }^{4}$ ainda era "novidade" no Brasil, os currículos dos cursos eram revistos e adaptados constantemente, de acordo com as modalidades que eram ofertadas. Senti, naquele momento, que havia um descompasso entre os conhecimentos adquiridos com a experiência de mercado e o que era proposto em sala de aula. Vivenciar a produção de produtos de moda, a confecção, e o universo que compõe o ato de empreender era uma realidade distante do que eu vivenciava no Curso de Moda. Talvez, em outras cidades e instituições essa realidade fosse diferente, cabe então aqui um esclarecimento. Esta introdução traz um relato de uma vivência pessoal, com uma

\footnotetext{
${ }^{1}$ O negócio envolvia uma linha de criação e confecção própria, e também de outros fornecedores, de roupas, acessórios e objetos de decoração.

${ }^{2}$ Não é fácil começar um negócio no Brasil, são diversos entraves burocráticos, mas pudemos contar com a ajuda dos colegas de feira que se tornaram nossos fornecedores, a maioria nos confiando produtos em consignação. Tal estratégia colaborativa amortizou os riscos do negócio e nos tornamos uma "multimarcas" de novos talentos.

3 "Chão de fábrica" é um termo utilizado no universo da indústria da moda que significa o contato com o ambiente onde ocorre o processo fabril de confecção do vestuário.

${ }^{4}$ Nessa tese, quando se emprega o termo "Moda" estamos nos referindo ao campo como produção de conhecimento e saber. Já o seu uso em minúsculo pode ser entendido sob a perspectiva dos modismos circunscritos a própria dinâmica do mercado e do consumo.
} 
narrativa que apresenta toda a subjetividade por trás das percepções que me levaram a essa pesquisa.

Uma passagem curiosa é que mesmo com experiência profissional anterior à minha formação, encontrei dificuldades para me inserir no mercado do Rio de Janeiro, por diferenças regionais que serão apresentadas no contexto da pesquisa sob o prisma das falas dos atores entrevistados. No âmbito da educação, minha sensação era a de que a universidade não investia em projetos facilitadores para a inserção dos seus alunos no mercado de trabalho e nem em iniciativas de estímulo ao empreendedorismo.

Tais dificuldades serviram para mim de motivação para a criação do "Metier da Moda" ${ }^{5}$, evento que idealizei utilizando o que tinha aprendido na prática, e cujo mote era propor um espaço de reflexão sobre temas da moda no contexto do mercado e da cultura e apresentar novos talentos com bazares e desfiles. Em iniciativa de outra natureza, desenvolvi projetos com o Terceiro Setor, em comunidades pobres do Rio de Janeiro, que alcançaram visibilidade e destaque na mídia. Nesse contexto, realizei trabalho com mulheres do regime semiaberto penitenciário ${ }^{6}$, para ensiná-las a desenvolver coleções de moda praia, especificamente biquínis, da confecção até a passarela.

5 Não pretendo aqui escrever uma extensa autobiografia, portanto, darei um salto para minha experiência após a formação universitária já trabalhando na área de educação. Sobre o Metier da Moda: http://janaramorenna.blogspot.com/p/metier-da-moda.html Acesso em 20 de março de 2019.

$6 \mathrm{O}$ projeto envolveu uma série de iniciativas, dentre elas as oficinas de moda praia, um incentivo para que as participantes pudessem aprender um novo oficio a fim de conquistarem maior independência do mercado formal de trabalho. 


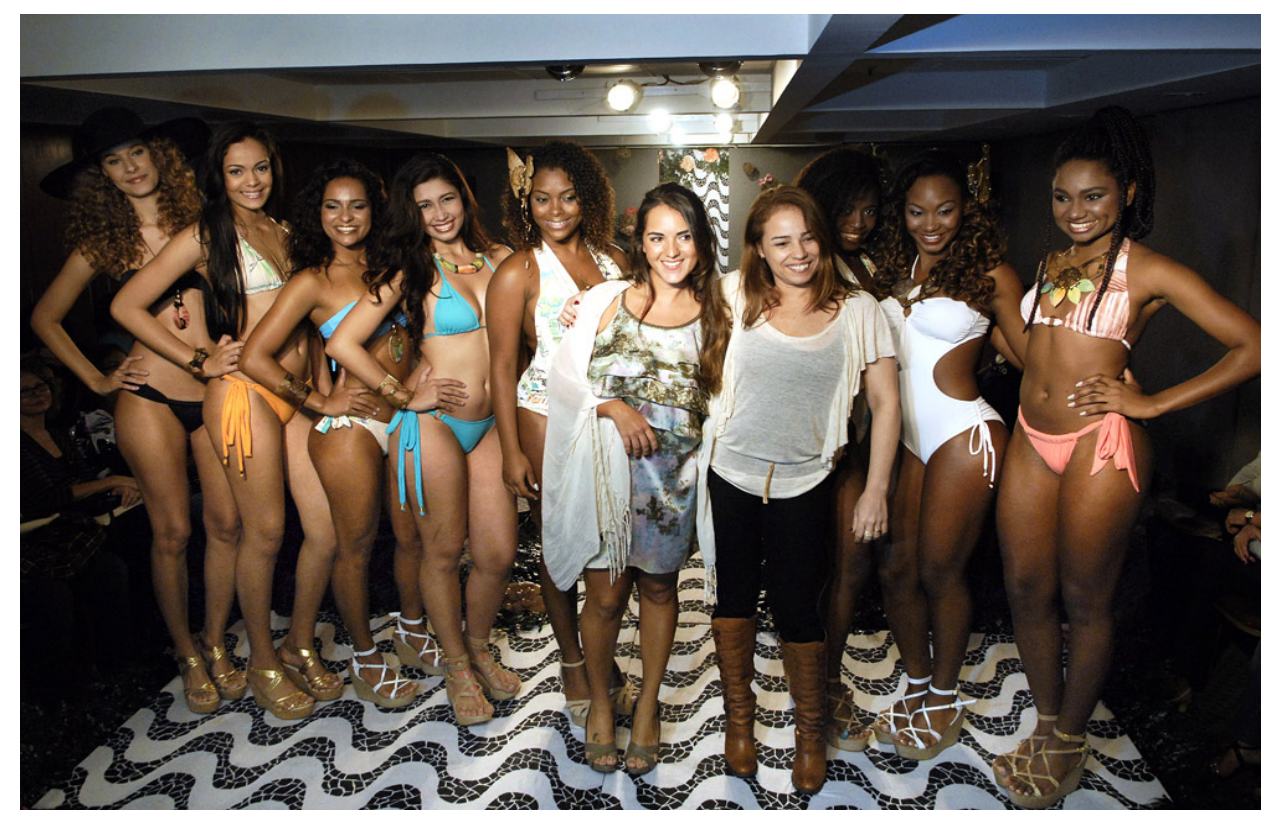

Figura 1: Imagem do arquivo pessoal da pesquisadora. Fotógrafo Enzo Gostolli, desfile realizado no Hotel Novo Mundo em 2011. Janara Morenna (no meio, à esquerda) e Fabíola Key com as modelos desfilando a moda praia do Projeto Amendoeiras.

Por se tratar de um segmento no qual eu não tinha tido experiência anterior, busquei encontrar referências ou publicações sobre cultura de praia e consumo, dentre outros, e sobre aspectos formais com dados atualizados do mercado. Ao longo do processo, fui percebendo que encontrar tais referências era tarefa difícil, inclusive na parte técnica para confecção, como modelagem, gradação e desenho.

Ao contatar profissionais do setor, tomei conhecimento que era comum que cada marca desenvolvesse suas próprias técnicas e bases de medidas para a modelagem. Portanto, não havia um padrão preestabelecido que servisse de referência. Verifiquei também que não havia muita oferta de cursos específicos sobre moda praia. Na época, nenhuma instituição estava ofertando, naquele período do ano, curso sobre o tema e não havia um calendário fixo para o oferecimento de tais cursos ${ }^{7}$. Nas aulas que tive durante o curso de graduação, no que diz respeito a moda praia, foram ensinados apenas dois modelos, um de biquíni e outro de maiô, utilizando uma base de modelagem

\footnotetext{
${ }^{7}$ No capítulo 4 há relatos de entrevistas com especialistas do Setor da moda da FIRJAN, com registros de diálogos que ilustram a oferta de cursos específicos no Rio de Janeiro.
} 
industrial que, na época, era bastante criticada pelos colegas de turma, por não corresponder ao que encontrávamos nas lojas mais jovens e famosas do Rio de Janeiro.

O aprendizado da vida deve dar consciência de que a "verdadeira vida", para usar a expressão de Rimbaud, não está tanto nas necessidades utilitárias - às quais ninguém consegue escapar -, mas na plenitude de si e na qualidade poética da existência, porque viver exige, de cada um, lucidez e compreensão ao mesmo tempo, e, mais amplamente, a mobilização de todas as aptidões humanas. (MORIN, 2001, p.49)

As dificuldades encontradas na busca por ferramental para projetar, desenhar, criar e refletir sobre a moda praia em um contexto historicista e da cultura de praia, me fizeram perceber que tais obstáculos faziam parte de um problema maior - e este merecia uma investigação. Até então, a conscientização do problema se inscrevia em uma situação problemática percebida empiricamente. De acordo com Laville e Dionne (1999, p.103), muitas vezes a problemática é mais vaga que racional, ela precisa ser construída e delimitada. A escolha da moda praia como objeto de estudo ao longo de duas etapas, o mestrado e o doutorado, foi uma evolução natural, levando-se em conta a minha imersão na busca por conectar respostas, ou antes disso, saber quais as perguntas corretas em meio a diversos aspectos de um mesmo objeto de estudo.

Quando sou questionada sobre qual a minha contribuição ${ }^{8}$ em relação ao investimento que fiz em torno do "biquíni”, muitas vezes, sou obrigada a explicar de forma simples e didática, que a partir de um objeto podemos refletir sobre seu entorno que concerne ao cosmo da nossa própria condição, somos seres ao mesmo tempo biológicos/físicos e culturais (MORIN, 2001). Sendo assim, meu esforço em reunir e organizar as informações e conhecimentos pertinentes ao meu objeto de estudo, a moda praia carioca, abarca diversas áreas - que estão na interface com o design, principalmente moda, administração, economia, sociologia, antropologia, comunicação e história.

\footnotetext{
${ }^{8}$ Em tempos de questionamentos sobre a produção científica na área das ciências humanas, para que o leitor incauto possa entender a relevância da pesquisa nesse âmbito, basta que ele as conecte com por exemplo, questões econômicas. Muitas vezes, a economia é vista como independente da complexidade dentro de contextos de produção, consumo e mercado, que são em última instância conduzidas por profissionais das áreas de humanas (comunicadores, antropólogos, psicólogos, profissionais do marketing e designers, esses que trabalham exatamente em uma mediação para o desenvolvimento de novos produtos e serviços).
} 
Neste sentido, busco contribuir com a ampliação do entendimento sobre a importância de iniciativas que fortaleçam a relação entre ensino e indústria na moda praia carioca, especificamente no segmento de biquínis, além de favorecer o desenvolvimento e consolidação de conhecimentos que poderão ser acessados por estudantes, professores, designers e empreendedores. São também bem-vindos, outros interessados em expandir suas percepções sobre a moda praia carioca, que apesar da sua força, carregada de uma dimensão simbólica, pode ser melhor explorada em suas potencialidades, em um contexto de mercado globalizado e extremamente competitivo.

A tese está estruturada em 6 capítulos. Começa apresentando o percurso metodológico com a contextualização e motivação para a pesquisa, incluindo os autores escolhidos para a fundamentação teórica. O capítulo 2 traz um olhar atualizado a partir do trabalho de mestrado sobre a moda praia e a formação desse segmento, dialoga com a história da cultura de praia no Rio de Janeiro e a relação entre corpo e design ao longo dos tempos, é um capítulo com enfoque na articulação entre cultura e mercado.

O capítulo 3 traz o enfoque sobre o panorama da educação no ensino do design de moda no Brasil sob a ótica de professores e alunos entrevistados ou participantes de grupos focais e questionários. O capítulo contempla também a experiência da pesquisadora enquanto curriculista dos cursos de moda do SENAI - Departamento Nacional.

O capítulo 4 com o ponto de vista dos representantes da indústria, traz entrevistas com notórios do setor, designers e profissionais do segmento nas áreas de modelagem, corte, pilotagem, produção e compras, além de visitas técnicas a empresas. Encerra nas visitas técnicas para diagnóstico e levantamento de informações sobre processos de design e produção no "chão de fábrica"

O capítulo 5 é dedicado aos experimentos de projetos pilotos desenvolvidos pela pesquisadora envolvendo alunos e empresas de moda, a fim de propor formas de aproximação entre eles. O objetivo de suscitar uma interação que resultasse em estágios dos alunos nas empresas.

A tese se encerra no capítulo 6 com as conclusões finais. O papel do designer que 
atua no segmento da moda como um potente diferencial competitivo de mercado percepção foi se delineando à medida que essa pesquisa avançava. Dentre diversas possibilidade de se definir as atividades do designer, partiu-se do entendimento de que, antes de tudo, o designer tem a capacidade de observar, articular, dialogar e conciliar o contexto cultural no entorno do projeto/objeto com o mercado, e em paralelismo seu conhecimento teórico-prático (ensino/experiência) com as possibilidades de produção e comercialização (indústria/mercado). O capítulo de conclusões oferece um balanço apresentando os desdobramentos futuros deste trabalho. Além disso são feitos registros de recomendações baseados em reflexões desenvolvidas ao longo de todo o processo.

\section{2 \\ Escolhas metodológicas}

Segundo Edgar Morin, o conhecimento científico é verdadeiro na medida em que se baseia em dados verificáveis, contudo, o progresso das certezas não caminha em direção a uma grande certeza (...), assim a ciência não é somente a acumulação de verdades verdadeiras (MORIN, 2013, p.24). Fazer ciência é um exercício de paciência, persistência e paixão - pois é necessário algo que nos mova, uma pulsão que promova tração no movimento da busca por organizar, seguindo os critérios e a obediência que o rigor acadêmico requer.

Estabelecer um diálogo coeso é necessário, mas se por um lado é tarefa do pesquisador conseguir separar seus "pré-conceitos" e ter um olhar distanciado, por outro lado, seria esquizofrênico pensar a anulação total da subjetividade intrínseca ao sujeito- pesquisador em seus afetos e do que lhe motivou a buscar determinados saberes. Nesse sentido, aqui propomos um diálogo com linguagem acessível a um maior número de pessoas para além dos já conhecidos “pares', reduzidos a uma ínfima parcela privilegiada da sociedade. Sendo assim, o texto segue sem a preocupação com a erudição ou em ser rebuscado em sua forma. Tal escolha não significa o esvaziamento de intensas reflexões, trata-se de uma opção de narrativa. 
Partimos do princípio da incerteza (MORIN, 2013) que é paradoxal aos princípios positivistas das verificações, dos processos e das precisões que o "método" científico preconiza. Não pretendemos instaurar grandes discussões sobre o ensino do design nem sobre a área da educação no ensino superior - sobre tais assuntos há extensa bibliografia, parte dela citada ao longo dos capítulos.

Esta tese foi sendo construída a partir do entrecruzamento de diferentes momentos do percurso de vida da pesquisadora: 1) enquanto designer autodidata e empreendedora; 2) enquanto aluna de moda; 3) enquanto designer e professora de moda praia; 4) enquanto pesquisadora no mestrado; 5) enquanto autora de projetos ligados à tecnologia e ao empreendedorismo. Sobre a última experiência, ao longo do processo de seleção para ingresso no doutorado, a pesquisadora foi agraciada com a seleção do seu projeto sobre moda praia no segmento da Indústria Criativa em um edital de incentivo à cultura da Secretaria do Estado de Cultura (SEC), do Rio de Janeiro. Tal iniciativa partiu da necessidade que a pesquisadora sentia em compartilhar os conhecimentos sobre a moda praia com um público maior. Para tal, o formato de exposições interativas foi desenhado e proposto no edital ${ }^{9}$. Seu escopo consistia em usar tecnologias oblíquas como realidade virtual e aumentada, Body Scanner, impressão e animação tridimensional, para compor uma narrativa sobre a história da moda praia no Brasil em suas extensões históricas, culturais e da relação corpo e design.

A fim de melhor entender e delimitar o campo, foi realizado inicialmente o levantamento bibliográfico incluindo autores das áreas de moda, sociologia, antropologia, economia, educação e história, tais como Gilles Lipovestky, David Le Breton, Michel Foucault, Lars Svendsen, Zygmunt Bauman, Edgar Morin, Enrico Cietta, Mary Del Priori, Mírian Goldenberg, dentre outros. Utilizou-se também dados de pesquisas de consultorias especializadas no setor e publicações em sites e aplicativos relevantes ao tema.

Durante a fase de imersão no campo, esta pesquisadora participou de projetos

\footnotetext{
${ }^{9}$ A aprovação do projeto viabilizava a captação de recursos para o desenvolvimento de uma exposição entre os anos de 2015 e 2018.
} 
de estudos prospectivos para o redesenho doe currículos de cursos de moda em nível nacional. Os comitês foram formados com representantes da indústria da moda e especialistas acadêmicos no SENAI. Tal experiência foi uma grande oportunidade para o desenvolvimento desta tese, uma vez que buscamos uma ênfase nas relações entre ensino e indústria.

Para atender aos objetivos traçados, cada vez mais foi se delineando uma metodologia de natureza essencialmente qualitativa e exploratória. De acordo com Marconi e Lakatos (1996), a pesquisa exploratória em geral é realizada em áreas nas quais há escassez de conhecimento acumulado e sistematizado, escolha bastante adequada para o objetivo proposto.

O planejamento para a pesquisa de campo foi realizado de forma orgânica, contemplando as oportunidades que surgiam para a obtenção de informações sobre a realidade do ensino e da indústria na área de moda. Desta forma, no período de 2015 à 2019 à medida que surgiam eventos, feiras, exposições e cursos de moda praia no Rio de Janeiro, as oportunidades foram sendo aproveitadas. Entrevistas presenciais com especialistas na área foram gravadas em áudio, com roteiros semiestruturados. $\mathrm{O}$ seu teor variava em função dos atores participantes, dos objetivos e das questões pertinentes a cada etapa. Os participantes entrevistados presencialmente autorizaram a utilização de suas imagens e áudios, assim como os participantes de entrevistas respondidas via e-mail.

Optou-se por uma seleção intencional de entrevistados e respondentes. De acordo com Marconi e Lakatos (1996, pg. 47), a amostra intencional é aquela em que o pesquisador está interessado na opinião de determinados elementos da população, sem que sejam necessariamente representativos da mesma. Esse tipo de seleção tem algumas restrições, como a impossibilidade de generalização dos resultados, tendo, portanto, a sua validade dentro de um contexto específico.

No caso dos representantes da indústria, os critérios para escolha dos entrevistados foram: notoriedade no setor, experiência comprovada de no mínimo 20 anos de mercado (incluindo indústrias, sindicatos e varejo). Além disso, foi préestabelecido que as empresas deveriam ser de médio e grande porte por serem detentoras de fatia relevante de mercado ("marketing share”). 
Para a escolha dos designers, buscou-se ouvir nomes representativos de marcas "top of mind”, com ampla experiência e notoriedade no segmento. Também houve a preocupação em dar voz aos novos empreendedores, estudantes de design, profissionais recém-formados de modo a fazer um contraponto. O contato com os atores entrevistados e respondentes ocorreu de diversas formas. Durante a pesquisa de campo foram indicados novos entrevistados, assim como tomou-se conhecimento de eventos e de projetos ligados ao ensino e à indústria que foram incorporados como oportunidades para a pesquisa. A pesquisa tem como tema a relação entre o ensino e a indústria no segmento da moda, especificamente a moda praia carioca.

\section{Problema, pressupostos e objetivos de pesquisa}

Embora a moda praia brasileira seja um exemplo de um segmento tido como referência na indústria nacional, existem diversos entraves para o crescimento deste mercado. Além das dificuldades econômicas, burocráticas e da falta de incentivos na esfera política no setor, verifica-se uma distância entre o ensino e a indústria impacta as diversas etapas dos processos da moda praia desde o desenvolvimento dos produtos até sua confecção e comercialização.

Assim, nesta pesquisa partimos do pressuposto que se houvesse mais iniciativas para aproximar o ensino da indústria e vice-versa, o mercado de moda seria favorecido como um todo, pois tais iniciativas conectariam os conhecimentos dos diversos atores ligados ao setor, desde a etapa do ensino até a comercialização do produto final. $\mathrm{O}$ diálogo entre o ensino e a indústria também contribuiria para um melhor entendimento sobre o papel do designer como conciliador e indutor de propostas inovadoras, envolvendo (em cadeia) a cultura local e a global. Nesse sentido, tais iniciativas potencializariam a moda praia brasileira para além da reputação já conquistada, mantendo-a como um benchmark nacional e como líder em um mercado extremamente competitivo e globalizado.

$\mathrm{Na}$ busca por respostas para as questões de pesquisa levantadas, e pela legitimação 
dos questionamentos feitos pela pesquisadora ${ }^{10}$ para além da subjetividade, a imersão no campo ocorreu por meio de diversas técnicas: entrevistas, visitas técnicas, participações em eventos, conferências, grupos focais, comitês técnicos e congressos. À medida em que a escuta avançava, os discursos dos atores envolvidos confirmavam como relevantes, aos poucos, as questões inicialmente colocadas.

As perguntas que nortearam a pesquisa foram: 1) como os atores do setor da moda enxergam a relação entre o ensino e a indústria? 2) Na visão dos participantes do setor, existem iniciativas de aproximação entre o ensino e a indústria de moda? Quais? 3) Como os atores da indústria e da educação estão se articulando para traçar o perfil do profissional que atuará no setor? Que habilidades, competências, ocupações, e projetos integradores? 4) Na visão dos atores envolvidos, a aproximação entre o ensino e a indústria poderia gerar que tipos de impacto a aproximação entre o ensino e a indústria poderia gerar na moda praia? e 5) Qual é o diferencial da moda praia carioca para que ela seja considerada um benchmark nacional da indústria em um mercado competitivo e globalizado?

O objetivo geral da pesquisa é, portanto, facilitar e fortalecer o diálogo entre o ensino e a indústria no setor da moda, a partir da visão da moda praia carioca, fazendo uma reflexão sobre possibilidades de iniciativas de aproximação entre os campos para o desenvolvimento e consolidação de conhecimentos na área.

Para atingir esse objetivo, definimos como objetivos específicos 1) pesquisar o que pensam os atores envolvidos no processo - coordenadores, professores e alunos de cursos de moda, designers, profissionais técnicos, representantes e especialistas da indústria da moda; 2) fazer levantamento bibliográfico para fundamentação teórica de questões conceituais referentes à cultura de praia no Rio de Janeiro, à relação entre corpo e design no segmento de moda praia (como um acompanha e influencia o outro ao longo dos tempos), às normas para confecção de biquínis em relação aos corpos

\footnotetext{
10 A pesquisadora frequentou desde criança as praias da Zona Sul no Rio de Janeiro, em especial Ipanema e Praia Vermelha. Entre os anos de 1990 e 2000 o culto ao corpo se evidenciava, alimentado pelos programas de televisão, e revistas de moda e comportamento. Desde adolescente, as questões ligadas à subjetividade, ao corpo e à moda sempre estiveram em seu radar de observação. Na vida profissional, as dificuldades que surgiram entre o mercado e o ensino (nessa ordem), foram elementos essenciais na composição das questões que surgiram nesta pesquisa - portanto, é preciso confrontar se tais dificuldades também promoveram indagações semelhantes do ponto de vista de diferentes atores.
} 
"fora da norma" de beleza vigente e à delimitação do mercado como segmento dentro da cadeia produtiva do setor têxtil e vestuário; e 3) Elaborar e aplicar propostas de experimentos para facilitar a aproximação entre ensino e indústria.

O trabalho de campo, abarcou diversos ambientes que podem ser categorizados como: ambiente de educação, ambiente de indústria e mercado e ambiente de comunicação. Foram feitas visitas técnicas a escolas de moda e laboratórios de pesquisa e inovação tecnológica/ têxtil e química para o levantamento da oferta de cursos, extensões e qualificações sobre a moda praia. Também foram feitas entrevistas com alunos de moda e grupos focais.

Foram feitas entrevistas com empreendedores recém-formados participantes de eventos de moda no segmento praia. A participação como integrante do comitê de desenho curricular ${ }^{11}$ do SENAI, Departamento Nacional (DN) realizado em Brasília foi de suma relevância para a pesquisa de campo no ambiente da educação e para ouvir a voz dos representantes da indústria na reformulação dos cursos técnicos do setor e superior de Design de moda.

$\mathrm{Na}$ indústria foram realizadas visitas técnicas ao "chão de fábrica" de empresas do setor e em suas respectivas lojas físicas, além das entrevistas semiestruturadas com notórios da indústria: empresários, representantes de associações de moda (ABIT), de sindicatos dos polos têxteis de moda praia e fornecedores de insumos, como a Rosset. Também foram entrevistados designers do segmento e demais profissionais da área de produção: engenheiros, modelistas, cortadoras, "cadistas" e representantes de marcas de moda praia de diversos.

$\mathrm{Na}$ interface entre a educação e indústria/mercado, o contato com a jornalista autora de publicações relevantes na moda praia e apresentadora de programas de televisão, Lilian Pacce e com a diretora das revistas Vogue, GQ e Glamour Brasil, Daniela Falcão, acrescentou uma visão panorâmica sobre o segmento da moda praia. Também destacamos a importante contribuição do antropólogo e sociólogo francês, David Le Breton quando em visita ao Rio de Janeiro.

\footnotetext{
${ }^{11}$ Redesenho de currículo utilizando a metodologia SENAI para atualização de diversos cursos técnicos de moda e do Curso Superior de Design de Moda.
} 


\section{3}

\section{Definir para dialogar: termos e conceitos}

Para se chegar a uma comunicação linear, é preciso antes de tudo contextualizar o leitor sobre os enunciados e pontos de partida a fim de reduzir os ruídos que dependem do lugar, época e da subjetividade inerente aos que terão contato com esse trabalho. Neste sentido, buscou-se estabelecer, de forma um tanto pragmática, uma ordem de termos, conceitos e definições dentro do que se propõe para a pesquisa.

As referencias e imagens que compõem uma arqueologia semântica se constituem a partir da construção de identidades. Surge das relações marcadas pelas diferenças em seu interior, locais e principalmente nas fronteiras e/ou globais. Um exemplo de cultura de praia local que se difundiu globalmente é a do sul da França. A força dos signos que compuseram as imagens que se tornaram icônicas para o ritual do banho de mar têm na sua origem a importância que os franceses deram para a praia como local de socialização e esportes durante o verão europeu ${ }^{12}$.

O "estilo navy" inspirado no uniforme dos marinheiros com listras brancas em contraste com preto, azul marinho ou vermelho, as alpargatas e os acessórios de corda foram tão replicados no mundo inteiro, que atualmente compõem "painéis imagéticos"13 na indústria da moda para além da moda praia. Pode-se aferir que tais imagens são sequestradas e apropriadas, seja para sua reprodução fiel, ou para a releitura e bricolagem colocadas em camadas com outras referencias e influências da cultura.

O levantamento histórico dos costumes no Brasil mostra como a moda Rio de Janeiro $^{14}$ surge desses movimentos de apropriação e reedição das modas europeias, muitas vezes de forma literal, ou seja, sem adaptações ao clima quente e tropical.

\footnotetext{
${ }^{12}$ De acordo com o levantamento histórico apresentado no capítulo 2.

${ }^{13}$ Os painéis imagéticos são muito utilizados como ferramenta de pesquisa e concepção de persona nas áreas de moda e marketing, ou na antropologia para estudos de comportamento consumidor. Pode ser chamado de painel semântico ou mood board. Apesar de sua ampla adoção no ensino, não encontramos autor de referência. Nota da pesquisadora.

${ }^{14}$ Neste caso, a referência à moda carioca de forma geral cabe no contexto apresentado. A moda praia seria um desdobramento com especificidades próprias, como veremos nos próximos capítulos.
} 
Contudo, achar que no Rio de Janeiro só se reedita a moda europeia ${ }^{15}$ seria limitar a representatividade de uma cultura pluralista e de praia carregada em seu cerne da complexa e intrincada heterogeneidade de um povo que reúne códigos sociais diametralmente opostos em um mesmo local, na praia.

Cultura de praia é um termo que abarca um conjunto de práticas peculiar que na cidade no Rio de Janeiro teve seu início é o século XIX, em função dos seus efeitos terapêuticos. Ao longo dos tempos, a praia foi paulatinamente se tornando um local de lazer e socialização na rotina carioca, para além da prescrição médica do período higienista (OLIVEIRA, 2014).

\begin{abstract}
Para mim, a cultura da praia no Brasil é múltipla. Não há apenas mulheres muito bonitas que mostram seus corpos como capital sedutor. Há também mulheres de todas as classes sociais, mulheres que podem ser mulheres muito fortes, mulheres muito magras. Mulheres de todas as idades. E para mim não existe apenas uma cultura costeira no Brasil, ou aqui no Rio de Janeiro. Há muita gente, há muitas condições sociais que se juntam, convivem, paralelas. É o meu sentimento sobre o corpo nas praias cariocas. (David Le Breton em entrevista concedida à pesquisadora em 13 de março de 2019. Tradução livree ${ }^{16}$ ).
\end{abstract}

Nesse contexto, observa-se empiricamente que se proliferam narrativas sobre o design de biquíni feito para corpos constituídos a partir de variáveis históricas, sociais, culturais, econômicas e tecnológicas. Utilizaremos “design de biquíni” ora como projeto, que engloba os processos necessários para que o objeto se materialize a partir de ideias, processos, planejamento etc. e, também no sentido formal/material do produto, que engloba estilo, corte, modelagem, formato ou shape, no vocabulário americanizado, muito utilizado no "meio" de moda brasileiro.

\footnotetext{
${ }^{15}$ Segundo a jornalista e pesquisadora Gilda Chataignier (2010), no Brasil a cópia das modas europeias, especialmente da França, está tão arraigada que era comum comerciantes experientes trazerem de Paris o que achavam que teria bons resultados comerciais no Brasil. As grandes casas de moda do início do século XX eram recheadas de modelos importados. Tal hábito ainda faz parte da rotina de muitas marcas que fazem suas pesquisas trazendo modelos de famosas grifes dos salões da moda europeia (p.121-124). 16 Pour moi, la culture des plages au Brésil est multiple. Il n'y a pas seulement des femmes très belles, qui montrent leur corps comme un capital de séduction. Il y a aussi des femmes de tous les milieux sociaux, des femmes qui peuvent être des femmes très fortes, des femmes très maigres. Des femmes de tous les âges. Et donc pour moi il n'y a pas qu'une seule culture balnéaire au Brésil, ou ici à Rio de Janeiro. Il y a énormément de monde, il y a énormément de conditions sociales qui se côtoient, qui vivent ensembles, qui sont en parallèle. C'est mon sentiment par rapport au corps sur les plages Cariocas. David Le Breton, 2019, 13 de março de 2019. Tradução livre.
} 


\title{
A moda praia
}

Destacamos o entendimento sobre moda, cultura e mercado como indissociáveis um do outro. Auto alimentam-se sob a lógica da engrenagem do consumo hedonista, próprio da efemeridade da contemporaneidade (LIPOVETSKY, 1987). Segundo o filósofo Lars Svendsen, para as teorias econômicas clássicas seria tarefa do consumo satisfazer necessidades já existentes. Contudo, tais teorias só alcançam áreas limitadas da questão do consumo que é complexo, não consumimos para somente suprir tais necessidades: "nós o fazemos provavelmente para criar uma identidade (SVENDSEN, p.129) uma vez que o consumo contém uma dimensão simbólica.

Dentro de uma lógica que compõe o entendimento da moda associada ao consumo, mercado e identidade, ocorre a organização das suas ramificações ou segmentos do setor. O segmento da moda praia produz códigos de construção da aparência (SANT'ANNA, 2009), cuja principal função da construção de um ethos relacionado ao seu ambiente/espaço, estilo etc., se conjugam na caracterização da cultura sob determinado aspecto:

\begin{abstract}
Esse conjunto, podendo mesmo caracterizar a cultura sob um determinado aspecto, é definido como "formismo". Essa categoria deposita na aparência a responsabilidade social de estabelecer relações entre os sujeitos e mesmo entre os diferentes grupos sociais, tornando-a tanto expressão quanto diferenciação e constituição de si. A forma é um agente social. Cada grupo constitui uma textualidade própria, constituindo formas exclusivas e um corpo imagético em sua historicidade (...). Com essas lentes de interpretação do mundo social, o corpo de cada sujeito é espaço de teatralização do texto que ele expõe aos seus pares. Nessa exposição-enunciação não apenas diz como deseja ser visto, como também constrói em si uma autoimagem que o significa para ele. (SANT'ANNA, 2009, p.20).
\end{abstract}

A moda praia com suas imagens publicitadas e propagadas de ambientes exóticos, relaxantes, paradisíacos e associados geralmente aos corpos positivados dentro das normas de beleza vigente, cabe perfeitamente dentro do que Gilles Lipovetsky chamou de "consumo da leveza" (xxx p.73). Parte de uma lógica que pressupõe uma vida leve, utopicamente fluída pelos ritos das práticas que potencializam as normas do corpo. O rigor para se alcançar inúmeras demandas de 
pertencimento para uma "vida leve" gera uma "pesada" ambiguidade: o fardo pela busca inalcançável de ideais de beleza conjugados com intensa dedicação e disciplina. Segundo o autor, quanto maior a autonomia individual, mais se intensificam as novas servidões do culto ao corpo que ele chamou de "tiranias" do neonarcisismo:

O recuo das restrições da honorabilidade social por meio da roupa tem como contrapartida um culto inquieto, obsessivo e sempre insatisfeito do corpo, marcado pelo desejo anti-idade, antipeso, antirrugas, por um trabalho de vigilância, de prevenção, de correção de si mesmo compartilhado pelos dois sexos; no entanto, mais sistematicamente interiorizado e praticado pelas mulheres. A tirania dos corpos apenas mudou de rosto e território. Ela estava centrada no vestuário, mas agora depende cada vez mais do corpo; era caprichosa; tornou-se "científica" e mais performativa; desejava a mudança perpétua, agora desejamos uma eterna juventude. A obsessão pelo vestuário enfraqueceu-se, a obsessão pelo corpo cresceu. (LIPOVETSKY, 2016, p.169)

No diálogo aqui proposto, não podemos deixar de fora a questão do corpo como objeto concreto de investimento coletivo. O corpo como suporte de significações e reunião de distinção social pelas práticas e discursos que suscita compõe a aparência relacionada a maneira escolhida para cada detalhe a ser exibido, desde a maneira de se pentear até a escolha da cor do esmalte. São atos dependentes da moda. Por outro lado, os aspectos físicos, como peso, altura, tom da pele, cabelo e demais características podem se metamorfosear, de acordo com o propósito de orientar o olhar do outro ou para ser classificado em uma categoria moral ou social particular (LE BRETON, 2017, p.77). As questões do corpo e da aparência, aqui brevemente relacionadas com o consumo na moda praia, dialogam com as escolhas do sujeito que pressupõe uma certa autonomia em relação ao poder que ele supostamente teria de se "moldar," de acordo com influencias do seu meio ambiente/entorno social.

A definição dada para "corpos remodelados" abrange aqueles que têm seus formatos e/ou volumes extremamente modificados. Ou seja, aqueles cuja forma é conquistada graças a práticas regradas que polarizam a vida de seus adeptos por meio de uma combinação de atividades esportivas, suplementação nutricional e medicina com fins estéticos.

A figura a seguir mostra os desdobramentos das dimensões do contexto do biquíni e do corpo no ambiente de "inovação" para "remodelagem" de ambos. Na conjuntura vigente, o designer aparece no centro como conciliador entre cultura (corpo) e mercado (design de moda praia): 


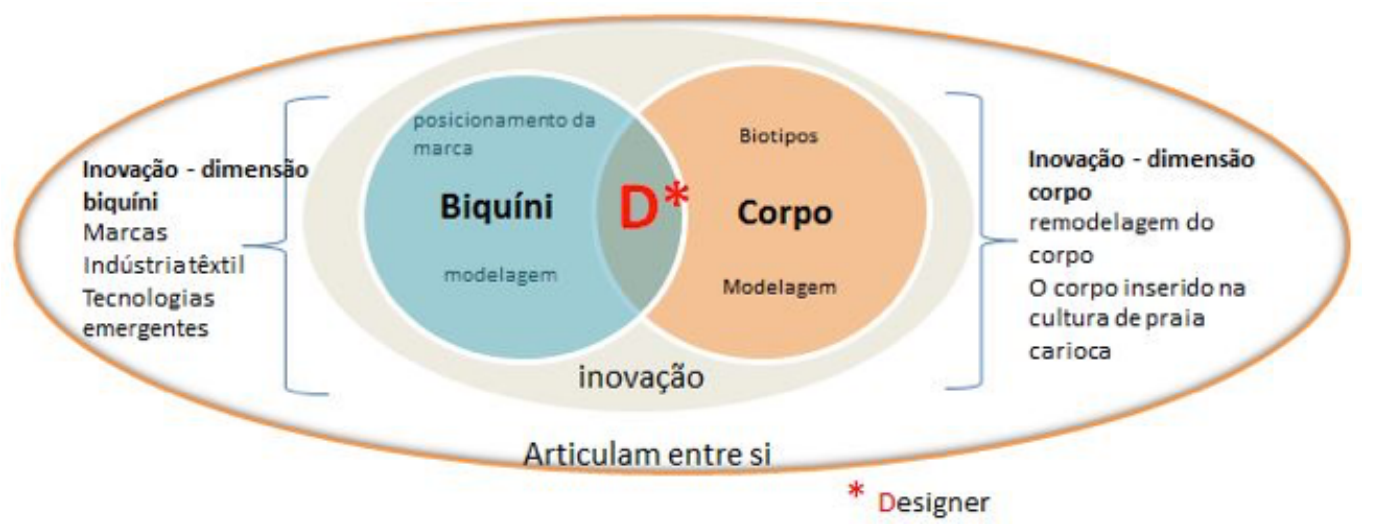

Figura 2: Elaborada pela pesquisadora entre 2012 e 2014 para dissertação intitulada "Relações entre o design de biquíni e o "corpo remodelado" na moda-praia carioca".

\section{O biquíni no universo da moda praia}

Nessa pesquisa, quando nos referimos à moda praia nos referimos a um entendimento de uma moda relacionada à cultura de praia, abarcando as noções de corpo/subjetividade, colocadas ao longo do texto. O termo moda praia engloba um conjunto de produtos, tais como: saídas de praia, sunga, bermuda, canga, biquíni, maiô, em seus diversos nichos (feminino, masculino, infantil etc.). Dentro da descrição de Nomenclatura Comum do Mercosul, ${ }^{17}$ a moda praia estaria representada por códigos divididos em 6 categorias, sendo 2 contendo "maiôs e biquínis, de banho, de malhas de fibras sintéticas" e "maiôs e biquínis, de banho, exceto malha".

Escolhemos a roupa de banho feminina, o biquíni e o maiô por serem os itens de maior destaque, cuja relevância pode ser mensurada de acordo com dados que serão apresentaremos a seguir, nosso recorte dentro da moda praia será sempre a roupa de

\footnotetext{
${ }^{17}$ Código 6112: Abrigos para esporte (Fatos de treino para desporto), macacões (fatos-macacos) e conjuntos, de esqui, maiôs (fatos de banho), biquínis, shorts (calções) e sungas (slips) de banho, de malha. Segundo nomenclatura Comum do Mercosul: Setor Têxtil e de Confecção, via ABIT. Fonte: https://www.abit.org.br/uploads/arquivos/NCMs\%20setor\%20t\%C3\%AAxtil\%20e\%20de\%20confec\% C3\%A7\%C3\%A30\%20(4\%20dig\%C3\%ADtos)\%20-\%20Atualizada.pdf, acesso em julho de 2019.
} 
banho feminina, especialmente o biquíni. ${ }^{18}$ Biquíni e maiô estão dentro da mesma categorização de roupas de banho no segmento da moda praia. A ênfase no biquíni ocorre por esse ser o objeto que historicamente causou impactos nos âmbitos culturais e sociais e, dessa forma, no mercado de moda no Brasil.

Ao longo da pesquisa, chegamos a alguns quesitos que destacam o biquíni dentro do conjunto dos produtos que compõem a moda praia. $\mathrm{O}$ de maior destaque seria a sua notória percepção de qualidade que vai desde o seu desenvolvimento das etapas da criação, passando pela modelagem, escolha da matéria prima, beneficiamentos e níveis de qualidade. Dentro dos aspectos tidos como intangíveis, esses considerados mais difíceis de mensurar, por dialogarem com a cultura local e a percepção de valor das marcas ofertadas, ${ }^{19}$ podemos destacar o trabalho feito por equipes interdisciplinares na construção da identidade de marcas que delimitam os nichos por posicionamento, de acordo com o público que se pretende atingir.

\section{4 \\ Cultura e mercado: dados sobre o cenário da moda praia no Brasil}

A moda praia do Brasil, e especialmente do Rio de Janeiro se destaca como sendo um exemplo bem-sucedido da indústria nacional devido a diversos aspectos, dentre eles a forte cultura de praia e do corpo. Nesse cenário, o Brasil se configura mundialmente como maior produtor e exportador de biquínis. As principais entidades

\footnotetext{
${ }^{18}$ No caso do maiô e seus impactos na moda praia global, sugerimos a leitura da tese intitulada Second Skin: Annette Kellerman, the modern swimsuit, and an Australian contribution to global fashion (2008), da pesquisadora Christine Schmidt, doutora em filosofia da universidade da indústria Criativa. Sua contribuição fala sobre a adoção de uma nova estética para os trajes esportivos femininos e como geraram impactos nas questões da emancipação do corpo das mulheres. Tal pesquisa deu origem ao livro The swimsuit: fashion from poolside to catwalk (acesso em abril de 2019 https://issuu.com/sherifabid1/docs/the_20swimsuit_20fashion_20from_20).

${ }^{19}$ Dentro dos atributos para que a marca seja percebida e identificada por seu público, o código simbólico ou o "DNA" da marca é fator determinante para sua relevância. Ele corresponde ao conjunto composto de capital humano, capital organizacional e capital de relacionamento da marca com o seu consumidor. O que envolve: público alvo, segmentação de mercado, posicionamento de marca, visão, missão e os valores que a regem, logo o DNA da marca envolve seus atributos tangíveis e intangíveis, em suma é a alma ou essência da marca. (STRUNK, 2007)
} 
a divulgar informações relevantes com dados demográficos e econômicos do setor são as ligadas ao governo e à indústria, especialmente o "Sistema S" 20 . O IEMI Inteligência de Mercado, um instituto privado de consultoria seria a principal fonte de informações usadas para a divulgação de dados do segmento.

A pesquisadora entrou em contato com a assessoria do IEMI em setembro de 2017 na busca por informações sobre os relatórios de moda praia, pois o Instituto costuma realizar estudos comparativos do segmento e em 2017, publicou o título “ Mercado Potencial de Moda Praia e Fitness ${ }^{21}$ ”. Durante o acompanhamento de informações sobre mercado, consumo e produção, a pesquisadora levantou diversas publicações cujas informações tinham como fonte consultorias como IEMI.

Tais informações rendiam diversos tipos de publicações como boletins, relatórios, conteúdo de cursos e matérias jornalísticas disponibilizadas de forma fragmentada em variados canais de comunicação. Serviam de base para replicação de conteúdos divulgados de forma homeopática, após algum tempo e não na sua íntegra, por entidades ligadas ao próprio Sistema S. Para os interessados no tema, a não ser que esses disponham de um alto investimento, restaria receber os conteúdos de acordo com a divulgação dos grupos ligados à indústria, ou seja, a informação acaba circulando essencialmente entre um grupo muito restrito de pessoas, deixando de fora grande parte dos pesquisadores, estudantes e os que desejam começar a empreender.

Segundo dados da Associação Brasileira da Indústria têxtil e de Confecção (2018, ABIT), a moda praia brasileira é responsável pelo faturamento de 1,9 bilhão de dólares por ano. Somente $10 \%$ dessa produção é destinada à exportação, número baixo em termos do potencial do mercado global, ao mesmo tempo o número é representativo,

\footnotetext{
${ }^{20}$ As entidades que compõem o "Sistema S" , ou serviços sociais autônomos, entidades de caráter privado e sem fins lucrativos, incentivadas por meio de recursos oriundos da indústria são: CNI (criado pela Confederação Nacional da Indústria) em 1942, SENAI, considerado o maior complexo de educação profissional e tecnológica da América Latina, SENAC (para educação profissional e técnica do comércio dentre suas variações de acordo com cada região como FIRJAN no Rio de Janeiro, FIESP em São Paulo e assim por diante.

${ }^{21}$ Tal conteúdo só era disponibilizado mediante a um custo de $\mathrm{R} \$ 8.900$ reais, valor que seria um entrave para estudantes interessados no tema, empreendedores pequenos e professores em geral.
} 
pois o Brasil lidera no mercado das exportações mundial, de acordo com o Boletim de tendência para o segmento de maio de 2018, realizado pelo SEBRAE, Inteligência Setorial $^{22}$.

A moda praia do Brasil teve seu desenvolvimento principalmente a partir dos anos de 1990, quando passou a registrar um crescimento constante com picos que nos anos 2000 atingiu uma marca expressiva de 202,4 milhões de peças produzidas, com crescimento de $12 \%$ sobre o ano anterior (1999) e 40\% em relação ao ano de 1990 . A partir de então, a moda praia se manteve com crescimento estável. Chegou a atingir novo pico em 2010, com 298,6 milhões de peças produzidas ou 48\% superior a maior alta anterior, em 2000. A partir de 2012 até 2015, coma crise econômica no Brasil, a moda praia não registrou crescimentos em relação ao consumo de outros segmentos do vestuário, o que leva a pensar que ela não seja um segmento essencial na demanda das famílias (IEMI, 2018).

Segundo dados da ABIT por meio do relatório de mercado do $\operatorname{IEMI}^{23}$ (2017), a região que lidera em unidades produtoras de moda praia é o Sudeste. Os dados comparativos entre os anos de 2012 e 2016, abrem uma diferença de 3 vezes mais produção na região Sudeste em relação ao Sul e Nordeste - praticamente empatados em segundo lugar. As ocupações de trabalho seguem os números acima. Segundo boletim do IEMI em agosto de 2018, nas últimas duas décadas o mercado de moda praia e de roupas para práticas esportivas, "fitness" cresceu exponencialmente com o aumento do poder aquisitivo da população brasileira nesse período.

O segmento é essencialmente composto por micro e pequenas empresas com expressivos $97 \%$ do total, gerando $66 \%$ dos empregos na moda praia. O Sudeste lidera não somente em termos produtivos, mas também no consumo, concentrando em pólos têxteis como na cidade de Cabo Frio (RJ) e Divinópolis (MG) grande parte da escala industrial:

\footnotetext{
${ }^{22} \mathrm{O}$ boletim é um apanhado geral com informações de consultorias como o IEMI, além de pesquisa bibliográfica, entrevistas e a curadoria de especialistas do setor vestuário e têxtil. Fonte: https:/www.iemi.com.br/mercado-potencial-de-moda-praia-e-fitness-2019/ Acesso em junho de 2019.

${ }^{23}$ Relatório Mercado Potencial de moda praia - 2017, enviado por representante da ABIT para a pesquisadora. Não disponível na íntegra em sites ou na internet.
} 
Também quando é avaliada a produção por região, tendo em vista os números de unidades produtoras e pessoal empregado, a região Sudeste se destaca por concentrar os maiores mercados consumidores e sediar os principais centros de distribuição de atacado e varejo do país. No Sudeste se concentra $48,1 \%$ da produção nacional, seguido do Sul, com $30,6 \%$, e do Nordeste, com $16,7 \%$. Centro-Oeste e Norte, juntos, responderam por 4,4\% da produção total de 2017 (IEMI, 2018).

As exportações projetam o país como principal player em relação aos países exportadores no mundo, como a China, Austrália, Estados Unidos e Itália. Contudo, o país fica muito aquém da sua capacidade de exportação. Um dos entraves para alavancar os negócios internacionais estaria nas dificuldades para internacionalização das marcas. De acordo com o IEMI e com a $\mathrm{APEX}^{24}$ - que tem como missão justamente atuar na promoção comercial dos produtos e serviços brasileiros.

A política cambial, as altas taxas de juros, as cargas tributarias elevadas e as questões trabalhistas somadas aos problemas estruturais como a logística para exportação, são pontos negativos; fraquezas em um mercado desleal em termos de concorrência com os países asiáticos. Os pontos fortes, nesse contexto, ficam por conta da excelência dos produtos em termos de qualidade e design - fato que ao longo da pesquisa se evidenciará de acordo com as falas dos entrevistados.

O Brasil também importa muitos artigos de moda praia da China. Dos importados são quase $80 \%$ da China, seguido Bangladesh como principais fornecedores do Brasil com diferentes itens do mercado. Aqui não cabe nos alongarmos sobre os detalhes da balança comercial, vale a reflexão sobre a participação de outros países no mercado global e interno brasileiro, tendo em vista as reconfigurações da produção industrial com as tecnologias disruptivas da indústria 4.0, como a automoção e a robótica.

Já no cenário das exportações, o principal país comprador é os Estados Unidos com 27,2\%, em seguida Portugal, com 7,6\%. Segundo relatório da IEMI $^{25}$, de janeiro à abril do ano de 2019, o mercado de moda praia exportou US\$ 10,9 milhões. Em 2017,

\footnotetext{
${ }^{24}$ A Agência Brasileira de Promoção de Exportações e Investimentos (Apex-Brasil) atua para promover os produtos e serviços brasileiros no exterior e atrair investimentos estrangeiros para setores estratégicos da economia brasileira. Acesso em abril de 2019, fonte: http://www.apexbrasil.com.br/blog/post/becreative-olha-que-coisa-mais-linda-mais-cheia-de-graca 25 Retirado do site Textilia de conteúdo sobre o setor, acesso maio de 2019, fonte: http://www.textilia.net/materias/ler/lingerie-praia-e-fitness/lpf-mercado/abit-discute-moda-praiadurante-evento-em-sao-paulo. A última pesquisa IEMI disponível foi em 2017.
} 
a produção de moda praia foi de 256 milhões de peças, totalizando US\$ 2,1 bilhões (dados IEMI).

$\mathrm{Na}$ linguagem de mercado, a moda praia é considerada um caso de sucesso, um benchmark $^{26}$ nacional. Apesar disso, há um descompasso entre o ensino e a indústria tornando o conhecimento em torno da moda praia desconectado e pulverizado, de acordo com as vozes dos atores envolvidos durante esta pesquisa e da experiência profissional relatada pela pesquisadora.

A pulverização dos conhecimentos ocorre em seus aspectos conceituais, históricos, técnicos e tecnológicos. Repercute na atividade do designer como projetista, na possibilidade de melhor promover inovação e, em cadeia, fortalecer a indústria em seu constante movimento e ciclos que dão origem a revoluções históricas marcadas por profundas mudanças que reconfiguram a geografia da produção mundial.

Sobre a atividade do designer, podemos aferir que no contexto apresentado ele teria um papel sobretudo conciliador ${ }^{27}$ entre cultura, corpo, mercado ou pela cultura por meio do qual a relação entre corpo e biquíni se estabelecem. Nessa perspectiva, o designer-conciliador propõe conexões e aproximações necessárias para projetos desenvolvidos por meio da reflexão e em um ambiente onde teoria e prática são exercitadas estabelecendo diálogos entre os campos que compõem sua atividade.

\footnotetext{
${ }^{26}$ Segundo Kotler, 2010, o Benchmarking, cuja tradução livre é "ponto de referencia", é a busca das melhores práticas na indústria que conduzem a um desempenho superior; significa também 'referência'.

27 Para maior entendimento da escolha do termo conciliar destacamos seus sinônimos na perspectiva para se referir ao designer: harmonizar, aproximar, tornar compatíveis, acomodar, acolher, adaptar, adequar, ajeitar, apropriar, reconciliar, acertar, ajustar, amoldar, aplicar, combinar, aliar, reunir, unir, persuadir, relacionar, concordar, compor, consertar, adotar, associar, manejar, ligar, sintonizar, compatibilizar.
} 


\section{2 \\ A construção da reputação da moda praia brasileira em suas extensões culturais, históricas e econômicas.}

Para pensar localizadamente é preciso pensar globalmente, como para pensar globalmente é preciso pensar localizadamente

\section{1 Apresentação do capítulo}

A necessidade de entender um objeto em sua complexidade, suas extensões culturais, sociais e estéticas é o ponto de partida que cimenta e direciona o que se pretende discutir sobre a relação entre o design de biquíni e a cultura de praia. $\mathrm{O}$ enfoque dado à formação da cultura de praia servirá como ponte para os próximos capítulos, visto que só a partir de tal entrelaçamento se torna possível pensar a relação indústria e ensino de moda.

No contexto vigente, cultura de praia é entendida como ethos, ou melhor, um espaço sócio recreativo caracterizado por um estilo de vida do carioca no qual o corpo é um atributo de valor. Parafraseando Michel Foucault ao analisar a cultura de si na Antiguidade, a cultura de praia em tal perspectiva diz respeito a um conjunto de valores e práticas cujo acesso está condicionado a procedimentos e técnicas mais ou menos regrados cuja elaboração, validação, transmissão e ensinamentos estão também associados a todo um conjunto de noções, conceitos, teorias, etc., enfim, a todo um campo de saber (FOUCAULT, 2010, p. 221).

Dito de maneira ainda mais explícita, cultura de praia, no contexto de um ethos social e estético ${ }^{28}$ caracterizado por práticas de culto ao corpo, é percebida nos moldes

\footnotetext{
${ }^{28}$ Estética é entendida como elemento de conformação do gosto, tal qual sugere (EAGLETON (1993), ou seja, entende-se que a ideia de um belo condicionado à normas ou regras objetivas através da valorização da genialidade do artista acaba por subjugar o contexto social no qual este se insere. Em outras palavras, pretende estabelecer a harmonia numa ordem instável e conflitiva.
} 
propostos por Foucault. Isto é, como uma organização hierárquica de valores que se aproximam de ética por meio da qual o sujeito desenvolve relação consigo próprio, a partir de técnicas de $\mathrm{si}^{29}$. Embora acessível a todos, constitui também um mecanismo de seleção e de exclusão, na medida em que solicita do indivíduo condutas regradas, dispendiosas, sacrificiais, que polarizam toda a vida (FOUCAULT, 2010, p. 221).

Para tal, é apresentado um panorama da chamada cultura de praia carioca por meio de uma coleta de informações históricas levantadas por pesquisadores de diversas áreas de conhecimento e cujo pano de fundo gira em torno desta cultura e seus modismos. Sendo assim, o trabalho se apoia em historiadores, antropólogos e filósofos que discutem elementos, como hábitos, costumes, consumo e moda sob uma perspectiva histórica.

O subcapítulo 2.2 é dedicado ao levantamento histórico e conceitual e teve seu desenvolvimento a partir de uma atualização do trabalho de mestrado elaborado pela pesquisadora, iniciado em 2012. A história do uso do biquíni no Brasil foi trazida para o leitor não como um levantamento focado no recorte essencialmente histórico. A ideia é, sobretudo, evidenciar os aspectos que contribuíram para a formação de uma cultura de praia e do corpo com os "ingredientes" necessários que resultam em práticas sociais que compõem o repertório complexo de um mercado de moda praia representativo e singular que é o brasileiro.

Já o 2.3 é dedicado a situar o leitor sobre a formação do mercado de moda praia e suas diversas variáveis: sociais, econômicas, demográficas etc. a partir do surgimento das marcas pioneiras de biquíni do Rio de Janeiro. Este recorte é dado pela vocação da cidade em relação à moda. Sendo assim, tem como foco o processo de “profissionalização da indústria" que se acelerou em meados dos anos 70 , posto que antes o biquíni era feito artesanalmente, geralmente em casa com restos de tecido ou

\footnotetext{
${ }^{29}$ Revisitando dados históricos no período greco-romano que compreende o Séc. V a.C. ao IV e V d.C., Michel Foucault busca entender relação entre sujeito e verdade. Nesse processo, identifica uma ética fortemente calcada em um princípio geral caracterizada por Foucault "cuidado de si"29. Através dele, os sujeitos são incitados a ocupar-se consigo mesmo por meio de um conjunto de práticas variadas que incluem uma série de exercícios. Para o autor, trata-se de uma importante ferramenta não só para a compreensão da história das representações, nem das histórias ou teorias das nações, mas da própria subjetividade, ou se quisermos, da história das práticas da subjetividade (FOUCAULT, 2010:11).
} 
em crochê. A partir de então, tornou-se oportunidade de negócios na visão dos pioneiros e, por conseguinte, um novo segmento de mercado.

O subcapítulo 2.4 trata do desenvolvimento do mercado de moda praia em relação ao contexto da hipervalorização de um corpo a ser construído a partir de diversas técnicas corporais em que o sujeito pode interferir em sua (re)modelagem por meio de um processo de subjetivação que confere ao indivíduo uma certa sensação de autonomia pelo próprio corpo. Discorremos então sobre os limites entre norma e resistência, assim como sobre as maneiras pelas quais o consumo se apropria das novas narrativas que surgem de um lugar do discurso da antinorma.

Na perspectiva foucaultiana, entende-se que o corpo é constituído no e pelo social e, por conseguinte, é caracterizado pelo social tanto em termos de seu constrangimento pelos poderes normatizadores que incidem nos corpos por meio de produção de subjetividades quanto sob a perspectiva que fura, rasga a norma por meio do que o Foucault (2004) define como processo de subjetivação. Sendo assim, o ato do sujeito interferir em sua remodelagem se configura como um questionamento dos processos de produção de subjetividades normatizadas, à medida que aparece aqui enquanto elemento, ou melhor, ferramenta de enfrentamento.

Esse processo de subjetivação se dá a partir de um processo de autopoesis. Isto é trata-se de um recurso no qual o sujeito se auto constitui como obra de arte a partir do que Foucault (2004) estabelece como estética da existência. O que envolve uma ética caracterizada por um esforço para afirmar a própria liberdade e dar a sua própria vida uma forma na qual se poderia reconhecer e ser reconhecido por outros e onde posteriormente poderia encontrar um exemplo (FORCAULT, 2004, p.290).

Por essa via de entendimento, o corpo remodelado de maneira extrema é frequentemente observado como um desvio, uma patologia. Nesse caso, são corpos não conformados, insubmissos ou não adaptáveis à norma como um padrão a ser seguido pelos sujeitos em seu conjunto. Nesse trabalho a norma diz respeito a duas noções que aparecem aqui entrelaçadas. Por um lado, se refere aos padrões de beleza vigentes na cultura globalizada (em um ambiente de hiperconexão, (trans)mídia, redes sociais, publicidade, televisão etc.). Por outro, a norma também se reporta aos limites 
e proporções de tamanhos para modelagem e confecção desenvolvidos pela $\mathrm{ABNT}^{30}$.

2.2

A formação da cultura de praia no Rio de Janeiro: do banho de mar terapêutico ao banho recreativo

Para se falar de moda praia no Brasil, é preciso antes fazer uma breve contextualização sobre como surgiu a cultura de praia. De uma forma geral, sabe-se que a "invenção" da praia como lugar de socialização e práticas corporais é recente em termos de civilização ocidental.

O levantamento histórico quando à luz da reflexão sobre a cultura contemporânea é uma fonte para o entendimento de modos e costumes do carioca frequentador da praia. O habitué das areias se relaciona com o corpo e o design de uma forma particular que foi sendo moldada através dos tempos devido ao contexto moral e social de cada época. A exemplo disso, temos de um lado o pudor com a prática do topless e de outro o despudor com modelos tidos como "ousados" de biquíni. Esse dualismo é algo que se naturalizou no Brasil e causa estranheza sob o prisma do olhar estrangeiro.

Em uma conversa com o antropólogo francês, David Le Breton ${ }^{31}$ sobre sua visão em relação à cultura de praia e do corpo no Rio de Janeiro o pesquisador disse que vê o design como um diferencial aqui, segundo ele a moda praia brasileira feita no é bem específica:

Particularmente o fio dental que não existe muito na Europa mas na Europa as mulheres podem tomar banho de mar com os seios nus, sem biquíni, (o topless) o que aqui não é possível. O que é muito interessante, mostrar que o pudor é diferente (Entrevista citada por David Le Breton, em 13 de março de 2019).

\footnotetext{
30 A ABNT - Associação Brasileira de Normas Técnicas é responsável pelo desenvolvimento de referencial para medidas para o vestuário - a norma NBR 13.377, contudo, a mesma engloba poucas medidas do corpo humano e foi gerada a partir de um consenso entre influentes da cadeia têxtil, e não a partir de estudos antropométricos dos corpos humanos na extensão brasileira.

${ }^{31} \mathrm{O}$ antropólogo e sociólogo francês que discute questões relativas ao corpo na contemporaneidade e possui diversas publicações em relação ao tema, tais como "A sociologia do Corpo" (2012) e “ Antropologia do corpo e modernidade" (1990) concedeu uma entrevista semiestruturada para a pesquisadora no dia 13 de março de 2019 na PUC-Rio.
} 
As especificidades na cultura de praia brasileira foram sendo construídas em camadas simbólicas num espaço temporal/cronológico, ao longo dos anos que se sucederam entre o lugar do discurso médico: praia-terapia e o da praia-recreativa. Foi a partir de descobertas no campo científico nas áreas da saúde e bem-estar que uma série de mudanças de hábitos ocorreram na forma como a sociedade se relacionava com a praia na cultura ocidental.

Antes do "mar virar a praia" ele era interpretado e reproduzido no imaginário longe do que se entende hoje como local de socialização e lazer. A princípio se tratava de um mar poderoso e sereno, belo e perigoso. Compunha um repertório dualista cheio de narrativas da mitologia. Ambiente hostil habitado por criaturas fantásticas, monstros e lendas, definitivamente o mar não se encaixava no modo de vida de uma sociedade tida como civilizada.

Enquanto o mar ia sendo "descoberto" para além das navegações e da pesca no hemisfério norte, no Brasil os índios desfrutavam de seus benefícios muito antes dos eruditos cientistas europeus. Com o advento das noções do higienismo que ocorre primeiramente na Europa, na primeira metade do século XIX, e com a popularização das técnicas terapêuticas impulsionadas pelas novas descobertas dos benefícios do banho de mar e da helioterapia ${ }^{32}$, a cultura de praia no Rio de Janeiro dá seus primeiros sinais, seguindo o modelo europeu.

\section{Praia terapêutica: antes da cultura de praia no Brasil}

No Brasil, devido a uma doença de pele causada por mordida de carrapato, D. João VI recebeu a recomendação médica para realizar a prática do banho de mar terapêutico $^{33}$. Diante dos resultados positivos do monarca, a praia-terapia se popularizou de tal modo que foi paulatinamente incorporada na rotina dos cariocas no

\footnotetext{
${ }^{32}$ Banho de sol como uma prática até hoje difundida por seus benefícios de cura que estimula a produção da vitamina D: hormônio ligado ao bem-estar, depressão etc.

${ }^{33}$ Acreditava-se que a mistura de sal, iodo e sol era boa para doenças respiratórias e de pele, mas para realizar essa prática existia todo um aparato, barcas para se chegar até as estruturas criadas para imersão em caixotes de madeira. Havia também um limite de 5 minutos para cada imersão e os horários para a terapia deveriam ser respeitados, na parte da manhã até as 8 horas. Nota da pesquisadora.
} 
século XIX. Segundo Claudia Braga Gaspar (2004), os propagandistas dos "banhos salgados" foram a família real:

Nisso D. João, mesmo refugiado na América Colonial, não poderia estar mais em dia com a última palavra da moda europeia. O século XIX acabou marcado pelo prestígio medicinal do banho de mar. Os médicos inspirados nos modelos das estâncias termais, o prescrevem para o tratamento de tudo e de todos - crianças raquíticas, jovens atacados por erupções cutâneas, mulheres estéreis leucorréia, neurose. De quebra debutavam na Europa os grandes hotéis de lazer, associados a cassinos e balneários. Autênticas cidades litorâneas brotavam do nada, com a construção de hotéis de praia, para onde acorre uma população ávida do ar marinho e de iodo para revigorar a alma e o corpo, procurando no mar o antídoto para os males da civilização. Não dizia Eurípides que ele "lava e limpa toda a sujeira humana"? (GASPAR, 2004, p. 81).

O sucesso do tratamento de D. João VI foi tanto que ele fundou sua própria Casa de Banho no Cajú - patrimônio até hoje mantido pelo Instituto do Patrimônio Histórico e Artístico Nacional (Iphan). Com esse gesto, a "cultura de praia" começa a ter seus contornos no Brasil, sendo estimulada e institucionalizada a receber banhistas em barcas de banho ${ }^{34}$. No início, a ideia de usar caixotes de madeira para imersões com água até o pescoço. Com o tempo a ideia foi sendo modernizada.

Surgiram as cabines de banho, muito comuns nas praias e resistindo até hoje na praia da Urca - anexo a um hotel balneário construído na ocasião. Era ali que as moças e rapazes trocavam suas roupas volumosas por trajes de banho também volumosos sob supervisão dos mais severos com as normas morais e avisos do tipo: "É expressamente proibido fazer furos nestas cabines; os encontrados serão entregues à polícia” (DEL PRIORI, 2013, p. 226).

A prática da helioterapia, que contribui para o bronzeamento também influenciou na mudança na percepção simbólica que atribuía à pele branca o sinal de status social, enquanto que a pele morena indicava origem proletária $^{35}$.

Após a II Guerra Mundial com a rápida difusão do estilo de vida americano na

\footnotetext{
${ }^{34}$ As barcas de banho eram camarotes separados, forrados em cobre e suspensos por correntes de ferro. Para ter acesso ao famoso banho terapêutico o banhista deveria pegar antes um bote até chegar às engenhocas.

35 De acordo com o levantamento histórico, exibir uma pele queimada de sol era sinônimo de inferioridade social e econômica - uma vez que os trabalhadores braçais antes da revolução industrial ficavam muito mais expostos a luz solar.
} 
Europa, do qual o lazer e o esporte são traços característicos dessa sociedade, novos códigos estéticos emergiram contribuindo para o surgimento dos primeiros trajes de banho, considerados naquela altura um insulto à moral, pudor e a decência ${ }^{36}$.

A historiadora Mary Del Priori em seu livro Histórias e conversas de mulher (2013, p. 225) destaca que os banhos de mar, apesar das restrições, tiveram importante significado para as mulheres por transcenderem a questão da saúde. Tais práticas acabaram por proporcionar novas oportunidades de convívio social.

\section{Praia recreativa: a cultura de praia no Brasil}

No início de século XX, a praia começa a ser importante para a cidade do Rio de Janeiro. A questão da limpeza das praias começa a preocupar os seus frequentadores, visto que por muitos anos as praias foram depósitos de lixo e até cadáveres.

A princípio, as mulheres tidas como "de respeito" só poderiam tomar banho de madrugada com muitas camadas de tecidos. Ao amanhecer, vestiam roupas pesadas que não marcavam a silhueta: cheias de laços, as modelagens amplas cobriam todo o corpo sem sugerir volumes como, por exemplo, os dos seios. O fato da mulher poder frequentar a praia já era em si uma revolução capaz de mexer com o imaginário dos homens (DEL PRIORI, 2013) - mesmo com tamanhas precauções com a exposição do corpo.

A revolução na moda praia também teve seu início marcado pelas novas exigências de uma sociedade obrigada a incluir as mulheres nas atividades cotidianas no período de escassez de mão de obra do pós-guerra. A nova silhueta da mulher que entrava para o mercado de trabalho deveria ser mais enxuta e versátil para suas atividades, como, por exemplo, para sua locomoção via bonde ou bicicleta. Nesse contexto, a mulher começa a se interessar cada vez mais por esportes.

\footnotetext{
${ }^{36}$ Cabe dizer que em outras épocas os Egípcios e Romanos já utilizavam o método da helioterapia, assim como no sul da península Itálica (nos séculos IV e V) os trajes de banho eram similares ao duas peças, precursor do biquíni, porém o objetivo era a prática de esportes, pois eles tomavam os banhos de mar nus.
} 
Para ter mais agilidade, a nadadora australiana Annette Kellerman ${ }^{37}$ usou uma peça única, algo que não era permitido às mulheres. Apesar da peça ter sido um modelo que cobria todo o corpo, o escândalo foi tão grande que ela chegou a ser presa. Após 1 século desde o episódio com a nadadora Annette, no Brasil as mulheres ainda são alvo de polêmica e perseguição de banhistas e da polícia local quando tentam um bronzeamento sem a parte superior do biquíni. A exceção do topless ocorre durante os desfiles de carnaval e a nudez em praias de naturalismo.

Enquanto o maiô gerava escândalo, a ida à praia era regulamentada. Severas leis ${ }^{38}$ de convívio eram implementadas, os horários eram restritos e havia códigos para a vestimenta. Tudo conforme a norma moral da época. O decreto legislava sobre o comportamento à beira mar da seguinte forma:

Vestuário apropriado, guardando a necessária decência e compostura vetando o trânsito de banhistas nas ruas que dão acesso às praias, sem uso de roupão ou paletós suficientemente longos, os quais deverão ser fechados ou abotoados e que só poderão ser retirados nas praias (GASPAR, 2004, p.43).

"Vozerios ou gritos" nas águas eram condenados, assim como "a permanência de casais que se portem de modo ofensivo à moral e decoros públicos nas praias..." que era proibido. A praia passa a ser mote de discussões sobre os novos hábitos e moralidade, delimitando o que poderia ser considerado decente, indecente, moral e imoral. Segundo Rose Esquenazi ${ }^{39}$, em seu artigo "As coquetes de Copacabana",40, as

\footnotetext{
${ }^{37}$ Kellerman ficou famosa por defender os direitos de as mulheres usarem maiôs de uma peça, o que era um escândalo na época. De acordo com um jornal australiano: "no início de 1900, as mulheres usavam pesadas combinações e calças quando nadavam. Em 1907, no auge de sua popularidade, Kellerman foi presa em Revere Beach, Massachusetts, por atentado ao pudor - ela estava usando um de seus maiôs de uma peça." A popularidade de seus maiôs de uma peça resultou na sua própria linha de roupa de banho para mulheres. Os maiôs "Annette Kellermans", como eram conhecidos, foram o primeiro passo para as roupas de banho femininas modernas. Fonte: http://neinordin.com.br/annette-kellerman-a-luta-peloespaco-num-mundo-de-homens-2 Acesso em 02 de dezembro de 2018.

${ }^{38}$ Em 1917, o decreto 1.143 do prefeito Amaro Cavalcanti (1849-1922).

${ }^{39}$ A professora Rose Esquenazi é formada no curso de Comunicação Social da PUC-Rio com mestrado no curso de História Social da Cultura, na PUC-Rio, Rose pesquisa sobre a TV e o rádio no Brasil em especial na Segunda Guerra.

${ }^{11}$ As 'coquettes' de Copacabana: no Rio do século XIX, elegância era seguir a moda francesa, por mais calorenta e desconfortável que fosse. Rose Esquenazi. Acesso em maio de 2018, fonte: https://ama2345decopacabana.wordpress.com/as-\%E2\%80\%98coquettes\%E2\%80\%99-decopacabana/
} 
leis que regulamentaram o uso da praia sofreram alterações de acordo com mudanças de hábitos e costumes da época:

Em 1886, em uma das quatro vezes que veio ao Brasil, a famosa atriz francesa Sarah Bernhardt (1844-1923) chocou as cariocas com um estranho hábito: deu um mergulho depois das sete da manhã. Será que os médicos não haviam alertado a diva do teatro mundial que fazia mal se banhar naquele horário e depois ficar sentada na areia, olhando o horizonte, pensativa? Demorou um pouco, mas a ousadia de Bernhardt acabou sendo absorvida pela sociedade. Em 1917, o decreto 1.143 do prefeito Amaro Cavalcanti (1849-1922) alterou o horário permitido de exposição ao sol. A partir daquela data, ficaram reservados dois periodos na orla de Copacabana: das $5 \mathrm{~h}$ às $8 \mathrm{~h}$ e das $17 \mathrm{~h}$ às $19 \mathrm{~h}$, com uma hora adicional nos domingos e feriados. Com oito artigos, o decreto apontava também a necessidade de "apresentar-se com vestuário apropriado na praia, guardando a necessária decência e compostura". Além disso, nada de "ruídos e vozerias" na areia e no mar. Punição para os transgressores: multa de 20 mil-réis ou cinco dias de prisão.

O decreto 1.143 pode ser considerado o primeiro "choque de ordem"41 instaurado para regulamentar o acesso às praias. Copacabana teve seus primeiros postos de salvamento no ano seguinte, em 1918, enquanto que Ipanema era uma praia inexpressiva para os banhistas da época:

A partir da segunda década do século XX, a praia deixou definitivamente de ser endereço terapêutico para tornar-se a melhor e mais saudável alternativa de diversão. O sol passou a ser aliado de homens e mulheres, com sinais do início do culto ao corpo atlético. A aventura nas praias do Rio rendia então seus primeiros grandes lances. (DISITZER, 2012, p. 43)

Com a construção do suntuoso prédio do hotel Copacabana Palace (1923), a cidade que antes dava as costas para o mar começa a despertar para um novo modelo que contribuiu para a formação do imaginário da cidade voltada para cultura de praia.

\footnotetext{
41 "Um fim a desordem urbana. A desordem urbana é o grande catalisador da sensação de insegurança pública e a geradora das condições propiciadoras à prática de crimes, de forma geral. Como uma coisa leva a outra, essas situações banem as pessoas e os bons princípios das ruas, contribuindo para a degeneração, desocupação desses logradouros e a redução das atividades econômicas. Com o objetivo de pôr um fim à desordem urbana, combater os pequenos delitos nos principais corredores, contribuir decisivamente para a melhoria da qualidade de vida em nossa Cidade, foi criada a Operação Choque de Ordem. São operações realizadas pela recém-criada Secretaria de Ordem Pública, que em um ano de existência vem conseguindo devolver à ordem à cidade. Retirado do site da prefeitura do Rio de Janeiro. Fonte: http://www.rio.rj.gov.br/web/guest/exibeconteudo?article-id=87137. Acesso em 15 de junho de 2018.
} 
Mais tarde, se tornaria responsável pelo atual sucesso do segmento da moda praia brasileira.

Os anos de 1920 foram marcados por reformistas, inconformistas e ativistas. O Brasil acompanhou esse período e com ele as transformações causadas pela queda da hegemonia europeia dando lugar aos novos holofotes do mundo: os Estados Unidos.

Em 1921, o maiô passa a pertencer às altas modas de salão na França. Pode-se dizer que seria o início de um comércio voltado para a moda-praia. Estilistas como Coco e Chanel Jean Patou deixaram suas contribuições criando modelos para "pós praia” e sofisticados maiôs para a prática da natação. Discretos, cobriam parte da coxa feminina e exibiam costuras em monogramas em estilo cubista, de acordo com o movimento artístico da época (OLIVEIRA, 2014, p.67).

Enquanto na Europa já era comum às mulheres ocuparem o espaço de seus maridos que serviam à guerra, consolidava-se também o movimento modernista, o Jazz e os movimentos Art Nouveau e Art Déco. ${ }^{42}$ No Rio de Janeiro, em clima de balneário europeu, o traje de banho era uma túnica amarrada com cinto marcando a cintura. O icônico Hotel Copacabana Palace - o "Copa” - ia se consagrando como a maior vitrine de um público tido como elegante e culto.

Além do Copa, havia também a Urca: um lugar elitizado de "exibicionismo plástico” que, segundos jornalistas da época, o local era narrado como uma experiência “mais civilizada" de praia. "Toma-se banho ouvindo música; dança-se na areia e bebe-se coquetéis dentro d'água" (DISITZER, 2012, p.55).

$\mathrm{Na}$ década de 1930, enquanto na Europa ocorre um racionamento geral inclusive de tecidos (por conta da Guerra), a prioridade em investir no militarismo resultava em uma moda mais enxuta, menos extravagante com cores discretas que refletiam o humor do momento. Já no Brasil, o clima de balneário trazia uma leveza que movimentava o comércio, restaurantes e lugares de lazer. A elite carioca frequentava bailes no Copacabana Palace, iam ao Jockey e cassinos enquanto o mercado de luxo crescia nas ruas do centro do Rio.

\footnotetext{
${ }^{42}$ No Brasil a influencia surge primeiramente em São Paulo com a primeira Semana da Arte Moderna (1922), um marco no movimento artístico e cultural do Brasil.
} 
No auge da inquietação que movimentava a sociedade carioca com os desfiles em casas luxuosas $^{43}$, a moda praiana seguia sóbria. Mostrar ombros e pernas era atitude adiantada e sensual. As modelagens eram feitas para tecidos, malhas e lãs. Somente em 1937 surgiu o náilon, lançado pela empresa Du Pont. ${ }^{44}$ (DISITZER, M. 2012, p.83). Essa inovação revolucionou a moda-praia da época. A partir de então, o uso do lastex foi sendo incorporado pelas mulheres tidas como “ousadas” . Elas podiam manipular o material para modelar melhor a silhueta no próprio corpo. Surge, em sua versão discreta, o maiô com transparência na barriga e os primeiros maiôs de duas peças.

Ainda na década de 1930, o bronzeado passa a ser cada vez mais sinônimo de saúde no Rio de Janeiro. As moças começam a frequentar a praia mais tarde para ficarem com o almejado tom "torradinha” . Vendo uma oportunidade de mercado, a empresa alemã Nívea lançou seu primeiro produto para o sol.

Destacando a importância de se adotar cuidados com a pele para se obter "a cor de saúde e o aspecto esportivo" (...) Além de produtos industrializados, uma série de misturas caseiras foram sendo adotadas por quem queria ficar com a cor do pecado. Valia tudo: Coca-Cola, urucum, óleo de cozinha e até casca de figo” (DISITZER, M. 2012, pg. 90).

A partir de 2012, surgiram algumas publicações (citadas ao longo deste trabalho) tratando da história do biquíni, comparando o "bikini” inventado na França ${ }^{45}$ com trajes usados pelos Egípcios e Romanos praticantes do método da helioterapia no sul da península Itálica (nos séculos IV e V). Os modelos, similares ao “tomara-que-caia” e a

\footnotetext{
${ }^{43}$ Como a Casa Canadá, que promoviam as moças de família a manequins, era uma época de glamour prestigiada pela imprensa, artistas e a alta sociedade (DISITZER, 2012, 78).

44 De acordo com o site da Du Pont, por mais de 40 anos, a DuPont oferece tecidos, fibras e nãotecidos em que indústrias para desempenho, proteção e versatilidade de uso. Fonte: http://www.dupont.com.br/produtos-e-servicos/tecidos-fibras-e-nao-tecidos.html acesso em 17 de março de 2019.

${ }^{45}$ Há uma disputa sobre quem seria o estilista criador do biquíni, ambos franceses, o mais reconhecido como tal chama-se Louis Réard, que apresentou em 1946 a calcinha em formato triangular semelhante ao modelo asa-delta com o sutiã que só cobria os seios, era o "bikini" batizado como tal em analogia ao Atol de Bikini, local onde os americanos realizavam testes de bombas atômicas. Assim como o "lugar explosivo", a invenção também foi considerada uma bomba. A peça era tão polêmica que para conseguir uma modelo que aceitasse desfilar com ela, o estilista teve que contratar uma dançarina de cassino, a primeira mulher a usar biquíni (OLIVEIRA, 2014).
} 
calcinha de biquíni "sunquíni" serviam para a prática esportiva, os banhos de mar eles tomavam nus (OLIVEIRA, 2014, p.67). A comparação dos trajes usados nos séculos IV e V não é correta quando pensamos no biquíni dentro da cultura de praia tal qual conhecemos, com seus entornos socioculturais na construção da subjetividade.

O biquíni foi considerado das mais importantes invenções do século. Para a famosa editora de moda, Diana Vreeland, ${ }^{46}$ a criação do biquíni foi de tamanha importância que estaria associada à emancipação do corpo na revolução feminina, de acordo com o acervo disponibilizado no site de Vreeland.

Embora seja onipresente nas praias hoje em dia, o minúsculo maiô, conhecido como biquíni nem sempre era elegante. Diana Vreeland viu pela primeira vez o que ela chamaria infame de "a coisa mais importante desde a bomba atômica" nas margens de St. Tropez nos anos que se seguiram à Segunda Guerra Mundial. Embora houvesse algumas roupas de banho modestas de duas peças, nunca havia visto tanta pele a luz do dia. Na época editora de moda do Harper's Bazaar, a Sra. Vreeland sabia que havia tropeçado em algo que mudaria a aparência da moda: um "traje de banho" que expunha "tudo sobre uma garota, exceto o nome de solteira de sua mãe". ${ }^{47}$

Fiel ao seu jeito irreverente, Vreeland causou alvoroço em seus contemporâneos quando, na edição de maio de 1947, da Harper's Bazaar, ela exibiu uma fotografia de Toni Frissell com uma modelo usando um biquíni de bolinhas verde e branca, tal imagem repercutiu escandalizando os mais conservadores. Em resposta aos escandalizados, Vreeland respondeu que "é esse tipo de pensamento que atrasa as pessoas por milhares de anos."

\footnotetext{
${ }^{46}$ Diana Vreeland (1903-1989) foi um ícone da moda internacional e editora-chefe das duas maiores publicações editoriais do ramo, Vogue e Harper's Bazaar, conhecida por sua criatividade ilimitada e seu forte temperamento, nasceu na França e viveu grande parte de vida profissional em Nova Iorque. Fonte: https://www.dianavreeland.com. Acesso em 04 de fevereiro de 2019.

${ }^{47}$ Though ubiquitous on beaches worldwide today, the skimpy swimsuit known as the bikini wasn't always in style. Diana Vreeland first spotted what she would infamously dub "the most important thing since the atom bomb" on the shores of St. Tropez in the years just following the Second World War. Though there were some modest two-piece swimming costumes, never before had so much skin seen the light of day. Then fashion editor at Harper's Bazaar, Mrs. Vreeland knew she had stumbled upon something that would change the face of fashion: a "swoonsuit" that exposed "everything about a girl except her mother's maiden name" (texto original, retirado do site). Fonte: dianavreeland.com (http://legacy.dianavreeland.com/page/posts/op/read/id/93). Acesso em fevereiro 2019.
} 


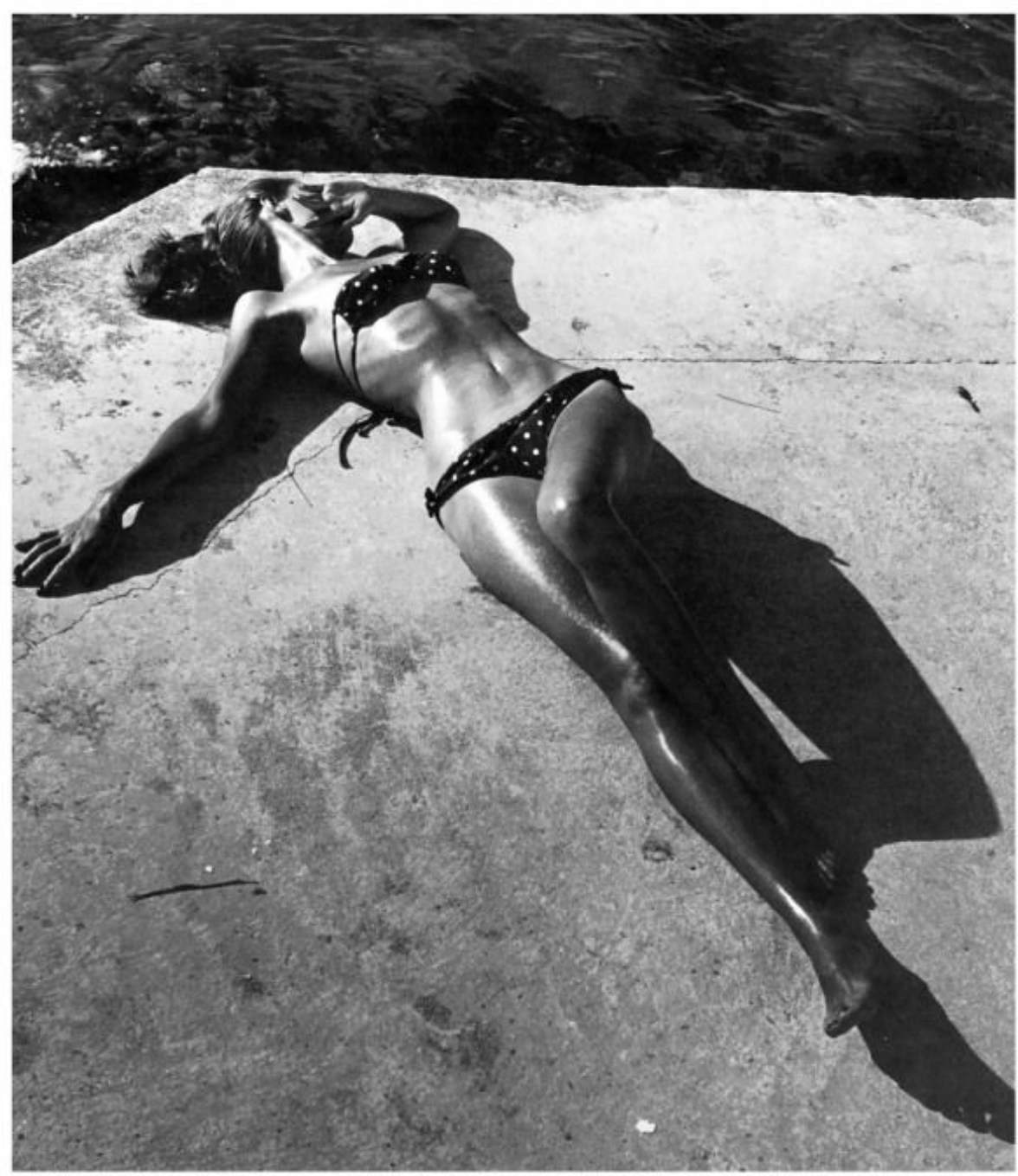

Figura 3: A senhora Vreeland choca com sua contemporaneidade, quando em maio de 1947, lança na Harper's Bazaar a fotografia feita por Toni Frissell de uma modelo usando um biquíni de bolinha.

Embora o biquíni tenha sido criado na França na década de 1940, ele chega ao Brasil somente no final de década seguinte, em tempos de glamour na então cosmopolita Copacabana. Seu uso ainda restrito foi primeiro adotado pelas mulheres mais ousadas ou as vedetes, dispostas a enfrentar leis rígidas que ditavam as regras para permissão de vesti-los. Naquela altura, o biquíni ainda choca e é considerado indecente. Estava sujeito ao regimento de leis que normatizavam a sua adoção.

Causando furor e confusão, a praia passa a ser mais controlada pelos guardas que vigiam os malandros impedindo-os de "tirar casquinha" das moças no reboliço das 
ondas. Era o início de uma "polícia marítima” (OLIVEIRA, 2014).

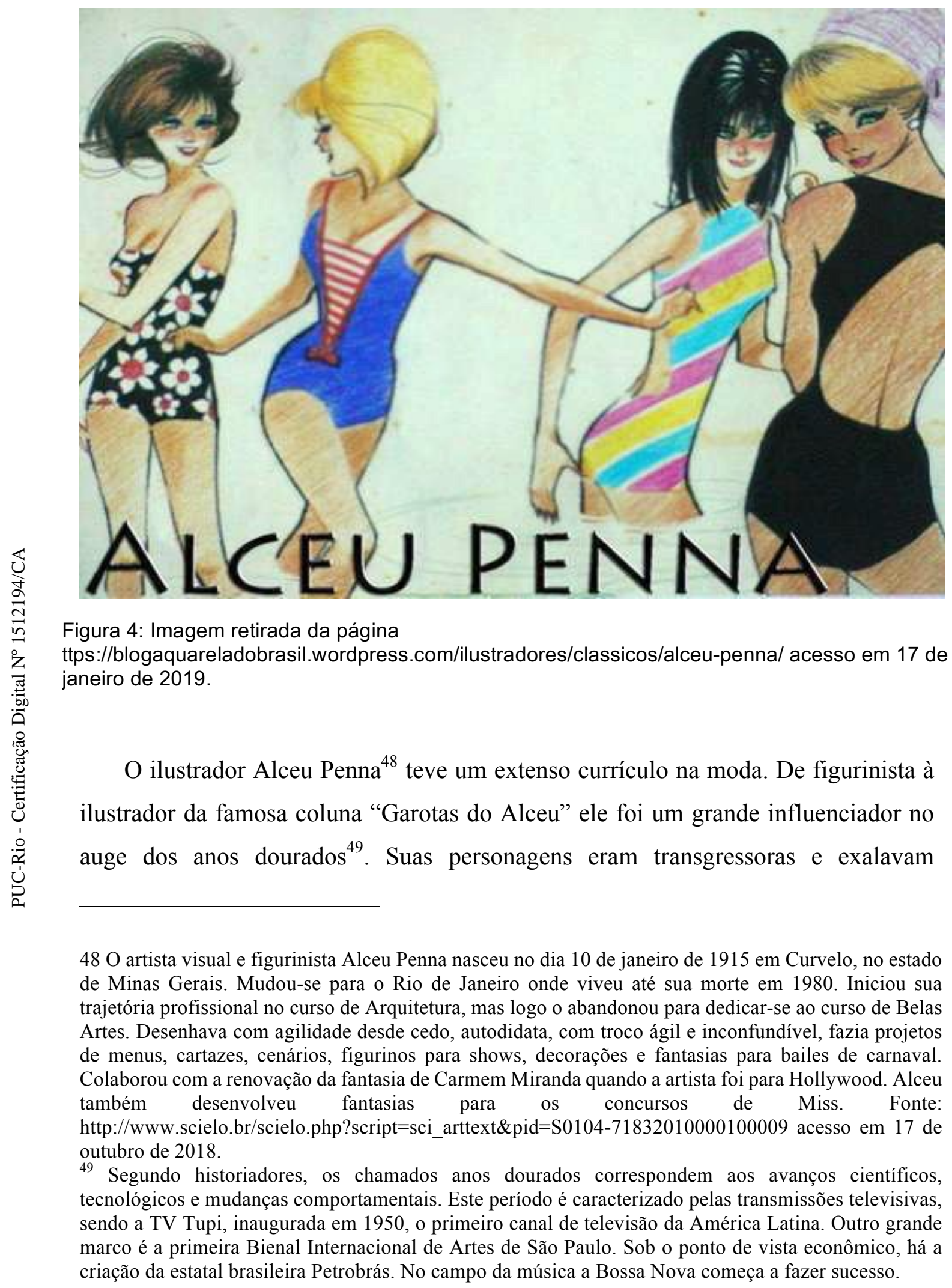


vanguarda com seus maiôs duas peças na praia de Copacabana. Suas ilustrações duraram muito tempo (de 1933 até 1964). Seus traços retratavam a evolução nas mudanças de hábitos, atitudes e comportamentos sociais da mulher (DISITZER, 2012, p.73).

As garotas do Alceu frequentavam a praia de Copacabana e as mais avançadas iam até o Arpoador, local tido como mais transgressor. A narrativa em torno das ilustrações acompanhadas pelos textos de diversos autores, dependendo da época, alimentava o imaginário da cultura de praia do Rio de Janeiro, como mostra a citação de Alceu Penna em 1950, cuja fala sobre o biquíni ficou famosa:

No início do século XX, as mulheres começaram a frequentar as praias [...] os trajes cobriam o mais possível as formas das senhoras [...]. Depois o conforto foi dando suas ordens, e os maiôs se encurtando (...) as pernas foram ficando inteiramente descobertas e surgiram os decotes nos ombros, colo e costas... Mas o encurtamento prosseguiu, e veio o duas-peças e depois o toque ousado com o biquíni. Parece que este modelo foi tirado do Teatro de Revista. Agora, perguntamos: o que faltará às mulheres que desejarem se exibir? A sua radiografia? (DISITZER, 2012, p.73).

Os eventos que surgem nos períodos que se sucedem ao desenvolvimento de uma indústria de moda praia são marcados por lutas simbólicas de emancipação feminina, principalmente com o advento do esporte em ascensão e com ele as novas necessidades de roupas que permitissem às mulheres maior performance. Trataremos do entrelaçamento entre moda, corpo e emancipação feminina no próximo subcapítulo. Por ser uma temática que aparece ao longo de todo trabalho e cujo enfoque se dá principalmente a partir dos anos 1940, contemplamos o recorte histórico a seguir.

\section{Biquíni e transgressão: a luta pela liberdade para usar o biquíni}

Enquanto o cinema americano disseminava sua cultura, as mulheres se baseavam no modelo hollywoodiano de comportamento social, nos modismos e claro, nos 
padrões de beleza propagados da época. Segundo professor Dr. Ivo Pitanguy ${ }^{50}$, a partir da década de 1940:

As mulheres eram influenciadas pelas heroínas consideradas ousadas para época. Trabalhar, dirigir, fumar, praticar esportes eram práticas consideradas transgressoras, portanto, serviam de fonte de inspiração e modelo de vida (OLIVEIRA, 2014, p.66).

No Brasil, a chegada tardia do biquíni foi protagonizada por uma alemã, Mírian Etz $^{51}$ causou furor no Rio de Janeiro, em 1948, ao usar um "maiô de duas peças" adaptado por ela mesma com o objetivo de tomar sol no umbigo, seguindo recomendações da saúde. Mírian inovou ao mudar a modelagem para exibir o umbigo, algo na época considerado indecente. Tal transgressão rendeu muitos constrangimentos segundo a própria, em entrevista realizada para o jornal “A voz da Serra",52.

Mirian achava o maiô inteiro vendido no Brasil muito caro e não gostava da modelagem dos maiôs Catalina que era moda na época (adiante falaremos da marca). O modelo criado pela artista era de algodão com laterais em crochê para dar mais vestibilidade e conforto. Tudo foi feito de forma intuitiva e improvisada.

Míriam conta que as pessoas que frequentavam a praia a descriminavam por sua ousadia, embora seu objetivo fosse a saúde, e não causar escândalo. Ela frequentava a praia do Arpoador que era perto de sua casa. Quando chegava por volta das 11 horas

\footnotetext{
${ }^{50}$ Entrevista concedida pelo cirurgião em 03 de fevereiro de 2014 para pesquisa de mestrado. O médico e professor Ivo Pitanguy, que além de precursor da cirurgia plástica, formou mais de 50 turmas com alunos brasileiros e estrangeiros, além de ter desenvolvido muitas técnicas e até instrumentos cirúrgicos que levam seu nome (em memória do professor Pitanguy toda a gratidão pela generosidade em compartilhar sua experiência e sabedoria, colaboração que foi peça central na construção da dissertação defendida em 2014).

${ }^{51}$ Erna Miriam Etz Kaufmann nasceu em 1914 na Alemanha de onde fugiu de bicicleta para a Holanda em 1934 por causa do nazismo. De família de artistas, conheceu seu marido na Inglaterra, o publicitário Hans. Chegaram ao Brasil em 1936.

${ }^{52}$ Em entrevista concedida para o jornal A Voz da Serra de Nova Friburgo, cidade onde Mírian viveu as últimas décadas de sua vida se dedicando às artes visuais. Realizada em 26 de julho de 2010 pela jornalista Dalva Ventura, link: http://acervo.avozdaserra.com.br/noticias/morre-a-artista-plasticamiriam-etz acesso em 07 de junho de 2018. Vale ressaltar que as passagens sobre a alemã foram levantadas em outras diversas fontes sobre a história do biquíni no Brasil e em uma oportunidade de conversa entre a pesquisadora e a filha de Mírian, Ira Etz que também participa no Rio de Janeiro dos encontros de "swimwear experts" do Bikini Art Museu da Alemanha.
} 
da manhã e a praia ia esvaziando, ela geralmente permanecia com uma amiga alemã atraindo a curiosidade a ponto de algumas pessoas pararem seus carros na rua para olhar (com malícia) seu traje. Algumas vezes ela era obrigada a "sair correndo" da praia para evitar constrangimento de alguns mais inconvenientes e safados (PACCE, 2016, p.60).

Durante os anos dourados, o concurso de Miss Brasil (1954) surgiu mexendo com o imaginário da época. Era produzido com o patrocínio dos maiôs Catalina. Marca trazida por um imigrante europeu fugindo da guerra na Alemanha. Ele se mudou para os Estados Unidos, depois para a Argentina e por fim para o Brasil trazendo a concessão da marca com ele. Hans Fischer sempre trabalhou com moda praia. Ainda quando vivia na Alemanha, fundou a marca de nome Goldfish no final do século XIX. No Brasil, tornou-se sócio do Grupo Águia ${ }^{53}$ para produzir os modelos.

A história dos maiôs Catalina e dos concursos de Miss Brasil se entrecruzam. Os maiôs eram confeccionados em tecido Strech e Helanca. Eram fabricados em teares circulares da Malharia Águia. Os modelos que vestiam as Misses eram bem fechados nos decotes, pernas e costas. Alguns ainda tinham sainhas, de acordo com a história da empresa descrita no site do Grupo Águia.

O pudor com a exibição do corpo feminino ainda era tamanho que, em 1950, o concurso de Miss América foi obrigado a mudar algumas regras quando a modelo vencedora Yolanda Betbeze se recusou a posar para fotos com o maiô Catalina, patrocinadora do evento. A atitude de Yolanda apontava para um novo status dos concursos de beleza, em que não apenas o físico era relevante, mas também a “inteligência, os valores pessoais e a capacidade de liderança da mulher".

Seguindo o modelo do concurso americano surge o concurso Miss Brasil ${ }^{54}$. O uso

\footnotetext{
${ }^{53}$ Fundada em 1937, como Malharia Águia na histórica cidade Imperial de Petrópolis - RJ, em pouco tempo obteve destaque por promover desfiles e competições de beleza tendo como principal destaque o concurso Miss Brasil e como principal palco o luxuoso Hotel Quitandinha. Os maiôs e biquínis brasileiros ainda não eram tão admirados como hoje, e por isso na década de 50 a empresa incorporou a já conhecida marca Catalina, que nasceu na Califórnia e era famosa por vestir famosas atrizes e patrocinar os concursos Miss Universo. De acordo com o site Águia, fonte: https://aguia.shop/pages/sobre-a-marca acesso em dezembro de 2018.

${ }^{54}$ De acordo com o levantamento histórico, o concurso de beleza feminino ainda é realizado anualmente no Brasil e visa eleger uma representante nacional com características da beleza da mulher brasileira. A vencedora de cada edição representa o país no Miss Universo.
} 
do biquíni nos concursos de Miss Brasil chegou a ser proibido, depois autorizado. Gerando polêmica, mais uma vez os maiôs Catalina representavam o concurso.

As medidas ideais exigidas para a participação do concurso de Miss Brasil, e que compunham o padrão de beleza ideal da época, eram traduzidas pelas formas e medidas da modelo Martha Rocha que, após ganhar o concurso no Brasil, participou da modalidade Miss Universo, mas perdeu por poucos centímetros a mais. As proporções eram: $90 \mathrm{~cm}$ de busto, $60 \mathrm{~cm}$ de cintura e $90 \mathrm{~cm}$ de quadril e o tornozelo deveria ter até $21 \mathrm{~cm}$. Martha Rocha foi o ponto de partida para o surgimento de outras modelos que inspirariam o padrão de corpo da época (DISITZER, 2013, P.107).

Passando pelas atrizes famosas do cinema americano ${ }^{55}$, ícones da beleza irreverente e dos atributos físicos do corpo no estilo "mulher violão" , a atitude da época era "rebelde" e as atrizes interpretavam usando o biquíni no telão. Tal propaganda caía cada vez mais no gosto popular devido à divulgação pelas então musas do cinema.

Com a chegada da televisão, a modelagem do biquíni vai diminuindo em uma época que anteciparia as décadas de maior relevância para a expressão de liberdade do corpo como extensão de significação da individualidade. Sua grande influencia é o apelo midiático e as novas opções de consumo, do prêt-à-porter e do advento do conceito dos adolescentes, os teen agers (OLIVEIRA, 2014, p.80).

Pouco a pouco, a tríade cultura da exaltação da beleza, da saúde atrelada à forma física e da efemeridade das tendências de moda, impulsionada pelos eventos como os concursos de beleza, foi influenciando as mudanças que resultariam novos modelos de peças de banho. As grandes atrizes americanas, europeias e as "musas brasileiras" promovidas pela mídia foram de grande importância no processo de naturalização/aceitação do uso do biquíni entre os anos de 1950 e 1960.

A partir de 1960, Copacabana perde seu status de "praia da moda" associada ao glamour aristocrata dos mais tradicionalistas. Ela é substituída por uma geração que transformaria para sempre a "cultura de praia ipaenense" . O local era ponto de

\footnotetext{
${ }^{55}$ Representados na época por atrizes como: Marilyn Monroe Jayne Mansfield, Doris Days, Debbie Reynolds, Andrey Hepburn e Gracy Kelly, além das europeias Sophia Loren, Gina Lollobrigida e Brigitte Bardot de acordo com levantamento histórico com os autores apresentados no capítulo.
} 
encontro entre intelectuais, artistas, macrobióticos, naturalistas, surfistas e diferentes tribos que discutia entre outros temas a política. Era em Ipanema que tudo acontecia para os jovens que buscavam na efervescência do bairro inspiração para bossas e modas.

Em 1961, o presidente Jânio Quadros ${ }^{56}$ tentou, sem sucesso, proibir o uso do biquíni com um decreto que não foi obedecido pela maioria das mulheres da época. As mais recatadas lançavam mão do modelo "engana mamãe": de frente parecia um maiô, mas de costas era como o biquíni (DISITZER, 2013, p. 159).

Os anos de 1960 foram um marco na moda feminina em geral. Na altura a maioria das mulheres frequentadoras da praia confeccionavam seus próprios biquínis pela dificuldade em encontrar para comprar. $\mathrm{O}$ imaginário da libertação sexual e o feminismo ganhavam força com o movimento estudantil. Neste contexto, surgiam as modas que colocariam, cada vez mais, o corpo em evidencia: minissaias, mini vestidos tubinhos amplos e uma estética futurística compõem um estilo andrógino e feminino:

Em tempos paradoxais, se de um lado havia a repressão da ditadura, por outro, havia movimentos como o Tropicalismo. O biquíni seguiu acompanhando um padrão ideal de um corpo magro, de acordo com o estilo de vida e hábitos da época - marcado por modismos na alimentação, que podia ser orgânica, ou macrobiótica, como parte de uma filosofia naturalista que envolvia também práticas de exercícios como meditação e alongamento. Os modelos eram baixinhos, geralmente em algodão, estampados e com as laterais largas, seria como o sunquíni atual. (OLIVEIRA, 2013, p.82)

As praias vão ganhando cada vez mais adeptos aos esportes como o Surf, as sandálias Alpargatas e os óculos de gatinho precedem a época em que as primeiras marcas especializadas na fabricação de biquínis estão em "período de gestação" . Os modelos mais populares de biquíni eram detalhados, costurados à mão ou em máquinas de costura no zig-zag. Fazia parte do estilo incluir babadinhos, lacinhos, acabamento em Laíse, algodão jérsei, bordado inglês, estampas de bolinhas, florzinhas e xadrez.

A indústria inova com a Helanca ${ }^{57}$ que contribui para que os modelos ficassem

\footnotetext{
${ }^{56}$ O presidente Jânio Quadros, durante seu meteórico governo, em 1961, baixou uma lei que proibia expressamente o uso do biquíni, em pouco tempo a lei saiu de vigor.

${ }^{57}$ Termo utilizado para designar o fio texturizado fabricado originalmente pela empresa Suíça Heberlein \& Co.; texturizado pelo método da falsa torção a partir de poliamida ou poliéster. O nome é uma marca
} 
mais cavados. Logo, viriam os tecidos sintéticos, que permitiram total aderência à pele. Secavam rápido e conferiam maior conforto e versatilidade.

Nos anos de 1970, a juventude do momento almejava por romper padrões e reforçavam a narrativa de "não querer repetir o que seus pais faziam" . Assim, os jovens começavam a ter voz. Engajados em movimentos que tomavam força com a chegada da pílula anticoncepcional traziam um novo repertório e novos códigos culturais, bem como estéticos para a praia. Ipanema virou point da vanguarda. Os habitués da praia saiam do Píer para os bares do bairro a fim de discutir política e cantar "Garota de Ipanema", canção imortalizada por Vinícius de Moraes e Tom Jobim.

Nesse contexto, surge a icônica imagem da primeira mulher grávida de biquíni. A irreverente atriz e modelo Leila Diniz ${ }^{58}$ escandalizou o Brasil inteiro ao estrear seu barrigão de seis meses na praia, em 1971. Uma coisa absolutamente impensável para época, até por conta da sua gravidez "fora do casamento" .

Naquela altura, as grávidas geralmente trocavam o biquíni pelo maiô, motivo pelo qual o episódio sinalizou mudanças no repertório das discussões sobre emancipação feminina e ainda de quebra ajudou a divulgar o biquíni brasileiro. Leila morreu jovem, aos 27 anos de acidente aéreo mas deixou um enorme legado como inspiração para as mulheres se libertarem dos dogmas morais da época.

Os anos de 1970 foram de mudanças no então mercado informal que começava a tomar contornos na moda praia. O período marca a passagem de um modelo de produção caseiro e sob demanda (em uma época em que era comum confeccionar

registada. Fonte: dicionário de definições do ramo têxtil. http://pt.texsite.info/Helanca_(fio_texturizado), acesso em 17 de janeiro de 2019.

${ }^{58}$ A personalidade irreverente da atriz que falava de sua vida com muita naturalidade foi considerada transgressora e censurada por conta de suas declarações: "você pode muito bem amar uma pessoa e ir para cama com outra. Já aconteceu comigo" ou então "transo de manhã, de tarde e de noite" . Considerada uma mulher à frente de seu tempo que detestava convenções foi criticada pela sociedade conservadora e pelas feministas que consideravam que ela estava à "serviço dos homens" . Perseguida pela polícia política, teve que se esconder para não ser presa. Teve até censura com seu nome, mais conhecida como "decreto Leila Diniz". Foi punida pela rede Globo que não renovou seu contrato como atriz. No carnaval de 1971 foi rainha da banda de Ipanema. (PACCE, 2016, p. 116). 
roupas em casa) e o início da produção em escala que deu origem às primeiras marcas especializadas em moda praia. As pioneiras deram o pontapé inicial para que a moda praia atingisse o patamar de "segmento de mercado" dentro da cadeia do setor de moda no Brasil.

O subcapítulo 2.3 tratará do surgimento das primeiras marcas de moda praia no contexto da cultura de praia e do corpo no Rio de Janeiro. Cidade conhecida por ser difusora de tendências de comportamento social e de estilo, de acordo com o levantamento histórico e de mercado. Cabe ressaltar que foi preciso fazer uma atualização do trabalho iniciado no mestrado a fim de que o entendimento sobre cultura de praia pudesse incorporar questões relativas ao consumo e à produção da moda praia a partir das relações entre ensino e indústria.

\section{3}

\section{A formação do mercado de moda praia: o surgimento das primeiras marcas}

As primeiras marcas de moda praia do Brasil surgiram na capital do Rio de Janeiro. Foram pioneiras nos desenvolvimentos de modelos próprios de negócios e das estratégias relacionadas ao contexto social, econômico e demográfico do momento. De acordo com os dados colocados no capítulo introdutório, a cidade do Rio de Janeiro se tornou polo de transformações na moda e referência para o Brasil com a "profissionalização da indústria" de moda acelerada em meados dos anos de 1970.

O início da moda praia no Brasil esta interconectado com os hábitos dos frequentadores da praia. As diversas "tribos" foram dando início à novos nichos. Ou seja, as marcas iam surgindo e se posicionando de acordo com o perfil do consumidor que elas queriam atingir. Para situar o leitor, correlacionamos as falas dos representantes das 4 marcas de moda praia escolhidas para entrevistas na etapa do 
mestrado com as atualizações feitas sobre o contexto das discussões sobre as normatizações dos modelos ideais de corpos versus o posicionamento das marcas ${ }^{59}$.

Com objetivo de fazer uma atualização do contexto das marcas, criamos uma conta no aplicativo de rede social Instagram ${ }^{60}$ utilizado globalmente para o comércio eletrônico. Atualmente, a referida rede social é utilizada por uma fatia bastante representativa que impulsiona por influenciadores digitais ${ }^{61}$. Além da divulgação de marcas, o aplicativo é usado não só como canal de comercialização e comunicação de marcas mas também para pesquisa de consumo, mercado e tendências de estilo e “comportamento" .

O uso da tecnologia a partir do aplicativo de celular Instagram se deu por este ser mais completo em relação à interface via computadores. O Instagram torna possível indexar uma quantidade imensurável de marcas de moda praia de todo o mundo com muita facilidade, pois o mecanismo (dados, algoritmos etc.) sugere ao usuário novos perfis semelhantes ao que foi buscado com atualizações constantes. A iniciativa de fazer esse acompanhamento de marcas e do mercado em geral começou em outubro de 2015. De lá para cá, a pesquisadora detectou mais de 800 contas associando modelos de moda praia e marcas. Este levantamento será apresentado adiante com os gráficos numéricos e por região referente ao universo das marcas de moda praia diagnosticadas ao longo de 40 meses.

As primeiras marcas de biquíni do Brasil nasceram no Rio de Janeiro. Não por

\footnotetext{
${ }^{59}$ As marcas além de precursoras no setor ainda se mantêm como representativas no cenário de mercado atual. As marcas Blue Man, Bumbum, Lenny e Salinas foram além de pioneiras as mais mencionadas pelas usuárias do Rio de Janeiro no trabalho de pesquisa realizado entre 2012 e 2014. Todos os representantes das marcas foram entrevistados. Alguns também foram reentrevistados de forma livre em diversas fases do período de doutorado

${ }^{60} \mathrm{O}$ aplicativo Instagram é uma rede social online de compartilhamento de fotos e vídeos entre seus usuários, que podem ser pessoas físicas, marcas, celebridades, empresas de diversos segmentos, especialmente de moda. Permite aplicar filtros digitais e compartilhá-los em uma variedade de serviços de redes sociais, como Facebook, Twitter, Tumblr e Flickr.

${ }^{61}$ Antes, as influenciadoras (no caso das usuárias de biquíni utilizamos no feminino) eram chamadas de blogueiras, pois, o meio digital que antecede o Instagram era o blog e quem produzia seu conteúdo eram as blogueiras. Atualmente, os blogs ainda são bastante utilizados, contudo, com a aderência em escala global do Instagram vieram novas ferramentas para facilitar as vendas online a partir das visualizações de fotos os blogs acabaram ficando mais direcionados para complementar as postagens do Instagram. Hoje o aplicativo é um meio poderoso e popular de promoção de marcas no mundo - nota da pesquisadora.
} 
coincidência, a cidade exalava uma moda vanguarda desde os salões da aristocracia aos pontos de encontro nas extensões de areias. O contexto de criatividade e ousadia em consonância com a reputação de ser lançadora de tendências e modismos da cidade contribuíram para que durante muitos anos o Rio de Janeiro concentrasse todas as principais marcas de moda praia do país. Segundo o jornalista Joaquim Ferreira dos Santos, "o carioca não nasce, entra na passarela. Vai lançando, nas praias e nos escritórios as modas que o Brasil inteiro adota logo em seguida" (DISITZER, 2013, pg. 11).

Em tempos de movimento hippie, feminismo e contracultura, a moda brasileira crescia com a aceleração da indústria. Junto, o biquíni é oportunidade de negócios surgida da inspiração das ruas. As lojas que apareciam em Ipanema redesenhavam uma nova identidade da cidade: carioca/ipanemense.

Os desfiles com superproduções eram performáticos e ousados. Em tom de protesto e tomada de consciência político-social, a moda cada vez mais se deslocava dos luxuosos salões aristocráticos para locais frequentados pela população como as estações de trem.

A primeira marca especializada em traduzir essa cultura de praia que ia sendo desenhada em produtos que despertavam o desejo de consumo foi a do David Azulay, a Blue Man lançada em 1972. David era frequentador assíduo das praias cariocas e se inspirou nas criações do seu irmão, Simão Azulay. A ideia veio de transformar pequenos pedaços de pano em uma oportunidade de fazer dinheiro com um investimento pequeno, já que a quantidade de tecido gasto para cada peça era mínima.

Segundo levantamento histórico, a criação do famoso biquíni de lacinho ocorreu por acaso. Depois de cortar e costurar diversas peças de biquíni em jeans e vender para lojas de multimarcas, o modelo de biquíni voltou para as mãos de Azulay. Por falta de elasticidade não poderia ser vestido. O criador decide então cortar as laterais e adaptar tirinhas costuradas, versão que poderia ser facilmente adaptada para diversos tamanhos de quadris. Assim, surgem as criações no início do cenário impreciso deste 
mercado, com muitas adaptações, tentativas, erros e acertos ${ }^{62}$.

Outro destaque no início do mercado de moda praia é a noção do valor da construção de uma identidade de marca que para Azulay se traduziria na pretensão de vender "ideias" ou “conceitos” e não simples peças do vestuário. David Azulay era enfático ao se colocar como alguém com uma visão ampla e conceitual do seu negócio: "não sou estilista, nem gostaria de ser. Estou muito mais preocupado em manter a ideologia da minha empresa: ser brasileira e ipanemense." ${ }^{63}$.

A marca Bumbum Ipanema começa a operar em 1979 sendo a pioneira no varejo de moda praia no Brasil. De acordo com seu fundador, Alcindo Pereira da Silva, conhecido como Cidinho, a Bumbum Ipanema chegou a abrir lojas em Ibiza, Manhattan, (USA), Califórnia (LA), Cascais (Portugal), Cocnut Grove (Miami) e em diversos pontos do Brasil.

Em 2012, a pesquisadora teve seu primeiro contato com o Cidinho ${ }^{64}$ e desde então trocaram inúmeras colaborações. O empresário declarou que "o que importa para ele é a modelagem na hora de projetar biquínis ". Em primeiro lugar, ela teria como função de conferir conforto, por isso uma das suas técnicas preferidas era a moulage feita diretamente no corpo da modelo de prova.

A partir dos anos de 1980 surgiram várias outras marcas "seguidoras” das que faziam sucesso no momento. Salinas, Rygy e Lenny são algumas referências da época em que o culto ao corpo extrapolava as noções de cuidado e manutenção; foi a época do exagero: muito brilho, cores cítricas, acessórios em acrílicos e corpos “sarados",65,

\footnotetext{
${ }^{62}$ A tanga aparece incialmente em 3 contextos: quando o biquíni é batizado na França, o modelo mais parece uma tanga de cós alto, em seguida aparece na modelo Rose de Primo (a atriz ganhou muito destaque nos anos de 1970 quando foi capa da revista Manchete em 1973, revista brasileira de grande circulação semanal comercializada entre os períodos dos anos 50 até os anos 2000) na qual montava uma moto vestindo um biquíni de lacinho e "cortininha" . A imagem da capa teve repercussão mundial e chegou a ser vendida até na Europa e terceiro teria sido mais uma criação do David Azulay. Lacinho, tanga e Lycra são as primeiras maiores inovações na moda-praia que levaram a marca Blue Man a ter destaque internacional. Fonte: Disponível em: http://www.blueman.com.br/blueman.php. Acesso em 01 de dezembro de 2012.

${ }^{63}$ - Trecho retirado da dissertação da pesquisadora. Frase extraída do site da Blue Man. Fonte: http://www.blueman.com.br/blueman.php. Acesso em 01 de dezembro de 2012.

${ }^{64}$ - Entrevista não estruturada realizada em julho de 2012, pela própria pesquisadora.

${ }^{65}$ Um corpo "sarado" no senso comum é uma gíria para designar um corpo trabalhado, musculoso e definido, resultado de muito exercício físico, alimentação apropriada e suplementação adequada à manutenção dos músculos e perda de gordura.
} 
inspirados em ícones como a cantora pop Madona (OLIVEIRA, 2014 p.89).

Nesse contexto, muitas inovações ocorreram na indústria têxtil, além do desenvolvimento de estampas exclusivas feitas pela empresa Rosset Têxtil. A exploração de padronagens exclusivas contribuía para que as marcas de moda praia se diferenciassem em seus posicionamentos de mercado, as dimensões dos produtos passavam por variáveis como: conforto, qualidade, durabilidade, sensualidade e beleza.

Podemos dizer que 1980 foi a década do corpo em evidência e por isso fez-se necessário um adendo. Trata-se de pausa para reflexão sobre este momento a fim de que, em seguida, se retomar a questão do mercado.

Esse corpo que se constrói, reconstrói e se remodela de acordo com a cultura de cada época é um corpo inspirado em proporções dignas das heroínas dos desenhos animados. É o corpo da "mulher maravilha" trabalhado em academia. Objeto a ser planejamento por profissionais de diversas áreas. É um corpo que contém o status dos que empregam disciplina e investimento para o acompanhamento das modas de remodelagem corporal que se proliferavam seguindo os modelos estrangeiros, especialmente o norte-americano (OLIVEIRA, 2014, pg. 68).

O Rio de Janeiro se destaca como campo fértil de inúmeras pesquisas, artigos e reflexões sobre as questões do corpo e da cultura. Por ser uma cidade litorânea cuja exposição da pele desnuda é maior devido sua forte cultura de praia, a cidade plural nas areias não corresponde ao modelo das revistas ou das modelos contratadas pelas marcas líderes de moda praia. Segundo o prof. Dr. Ivo Pitanguy em entrevista realizada em 03 de fevereiro de 2014:

Eu acho que o Rio segue o que todas as cidades que tem praias ditam de um padrão (de corpo) que é mais trabalhado, de um padrão que é mais exposto, então quando o corpo é mais exposto você tem o trabalhar o corpo para o carnaval, e que brincadeira é essa? E preparar para o verão? São coisas que você vê toda hora escrito. E por quê trabalhar para o verão? Porque vai ser no verão que todo mundo vai expor o seu corpo, em qualquer idade, vão se cuidar um pouco mais para apresentar ao seu público que é todo mundo. (Entrevista concedida por Ivo Pitanguy em 08 de novembro de 2014).

Seguindo a lógica da responsabilização do indivíduo pela sua própria forma corporal, em nome da saúde e da "boa forma" nem sempre o corpo é remodelado a partir de técnicas realmente saudáveis. O famoso "culto ao corpo" e a busca pelos 
padrões ideais de beleza gera também ambiguidades. Por um lado, existe uma oferta crescente no mercado da beleza, o que de certa forma facilitaria a busca por esse " ideal", normalmente, longe do alcance da maioria das mulheres ${ }^{66}$. Por outro lado, contribui também para o crescente número das "doenças da beleza" , são elas: anorexia, bulimia, vigorexia e compulsão, dentre outras, de acordo com o Núcleo de Doenças da Beleza do laboratório LIPIS ${ }^{67}$ da Pontifícia Católica do Rio de Janeiro.

Sabe-se que embora exista o apelo a um modelo "ideal" e cultural para a forma de um corpo físico dominante, há no Brasil uma diversidade de biótipos quando se trata de um país com extensão continental e influencia de diversos povos desde o processo de colonização. Contrariando muitas vezes o que a genética tende a moldar, a plasticidade do corpo deixa aparente as marcas de suas formas na construção de uma identidade através do estilo que reflete a busca ou o relaxamento em relação aos ideais mainstream de beleza.

A adesão por intervenções de todo gênero depende de como o indivíduo se afeta pelo ideal físico mais desejado do momento e de acordo com sua capacidade de investimento. Essa adesão é proporcional ao processo de responsabilização do indivíduo pelo seu corpo, nas palavras de Baudrillard, (1995) "o corpo virou o mais belo objeto de consumo", já que o poder disciplinador pelo qual as pessoas são afetadas é exercido por meio da mídia, televisão, filmes e publicidade.

Segundo levantamento da revista Veja (em 17 de janeiro de 2001), a partir de dados coletados desde 1990, o Brasil se encontrava em segundo lugar depois dos Estados Unidos no ranking em termos quantitativos de cirurgias plásticas. Há uma certa confusão em relação aos dados sobre este ranking entre Brasil e Estados Unidos. De 2013 para cá, talvez por conta do SUS ${ }^{68}$ (Sistema Único de Saúde) e das cirurgias

\footnotetext{
${ }^{66}$ Vale destacar que a pesquisa foi em cima da moda praia brasileira feminina por ela ser representativa em termos de relevância de mercado e atributos (qualidade, design, inovação etc.).

${ }^{67}$ O núcleo de doenças da beleza sob coordenação da pesquisadora Joana de Vilhena Novaes e equipe LIPIS oferece atendimento psicológico para portadores de transtornos alimentares e/ou relacionados à imagem corporal. Anorexia, bulimia, obesidade, cirurgias plásticas, bariátricas e ginecologia estética são trabalhadas em uma perspectiva multidisciplinar, de acordo com o site do próprio núcleo. Fonte http://lipis.usuarios.rdc.puc-rio.br/estrutura.html acesso em 10 de fevereiro de 2019.

${ }^{68}$ Segundo Ministério da Saúde, o Sistema Único de Saúde (SUS) é um dos maiores e mais complexos sistemas de saúde pública do mundo, abrangendo desde o simples atendimento, até o transplante de
} 
reparadoras (acidentes, queimaduras etc), esse número pode ter colocado o Brasil na liderança por algum período, como ocorreu em 2013, segundo reportagens sobre o tema ${ }^{69}$ :

O Brasil ultrapassou os EUA em número de cirurgias plásticas e se tornou o líder mundial nessa área, respondendo por $12,9 \%$ dos 11,6 milhões de procedimentos. O país fez 1,49 milhão de operações estéticas em 2013, contra 1,45 milhão dos EUA, aponta relatório da Isaps (Sociedade Internacional de Cirurgia Plástica Estética).

A reputação do Brasil em relação aos cuidados com o corpo, formas e pele, e especialmente no Rio de Janeiro, também contribui para o grande número de escolas de formação na especialidade. Vale dizer que os procedimentos cirúrgicos de correção e harmonização corporal também são disponibilizados em hospitais públicos por meio dos programas de residência médica em cirurgia plástica.

O serviço de cirurgia plástica é voltado para principalmente cirurgias reparadoras: "os médicos residentes fazem a cirurgia estética por conta da formação, uma vez que fará parte da realidade deles a estética também", segundo cirurgião Dr. André $\mathrm{Ahmed}^{70}$. Na fase da residência, os médicos efetuam procedimentos sob supervisão dos chefes de cirurgia (staffs). O grau de exigência para seleção dos pacientes é alto: ele deve ser não fumante, não ter doenças que possam comprometer a cirurgia e estar no peso ideal orientado pelo médico, pois a fila e a demanda são muito grandes para procedimentos como a mamoplastia redutora (redução da mama) e abdominoplastia.

Esses médicos cumprem dois anos de residência em cirurgia geral para prestarem o concurso para a residência em plástica, que dura mais três anos. Nesse contexto muitas mulheres de classes menos favorecidas economicamente podem desfrutar da oportunidade de serem operadas. Elas se inscrevem nos hospitais públicos que oferecem a residência em cirurgia plástica reparadora e estética e aguardam em uma fila. Algumas chegam a entrar em uma lista de espera várias vezes para novas cirurgias. (OLIVEIRA, 2014, p.45)

A partir de 1980 surgem as "musas do Jornal do Brasil" que eram mulheres

órgãos, garantindo acesso integral, universal e gratuito para toda a população do país. Fonte: http://portalms.saude.gov.br/sistema-unico-de-saude, acesso em 17 de janeiro de 2019.

${ }^{69}$ Disponível em: https://www1.folha.uol.com.br/equilibrioesaude/2014/07/1493030-brasil-ultrapassaos-eua-e-se-torna-lider-de-cirurgias-plasticas.shtml. Acesso em 02 de abril de 2018.

70. O médico André Ahmed fez sua residência em cirurgia geral no Hospital de Ipanema e no Hospital Barata Ribeiro em cirurgia plástica entre os anos de 2010 e 2013. (Entrevista semiestruturada sobre o contexto da cirurgia plástica no Brasil - realizada por telefone em 22 de fevereiro de 2019). 
frequentadoras assíduas das praias da zona sul do Rio de Janeiro (DISITZER, 2013, p. 211). As musas eram reconhecidas e eleitas por personalidades, jornalistas e artistas que as escolhiam de acordo com o ideal de beleza feminino de cada verão carioca.

$\mathrm{Na}$ altura, a prática do topless não emplacou mesmo tendo como garota propaganda modelos como a Monique Evans ${ }^{71}$ frequentadora da faixa de areia em frente a rua Farme de Amoedo em Ipanema. O point das mulheres que arriscavam aderir o topless. Apesar do topless não emplacar, em compensação, o criador da Bumbum Ipanema inventou o ousado modelo Asa Delta. Ao mexer na modelagem da calcinha, evidenciou as pernas e o bumbum feminino.

O corpo torneado pelo esporte e malhação foi inspiração para a marca Bumbum Ipanema que valorizava a prática esportiva, principalmente o surf e o voo livre (DISITZER, 2013, pg. 225). A marca propôs uma mudança também na forma de exposição dos produtos. O biquíni saiu das sacolinhas onde eram guardados enroladinhos em cestas e passou a ser exibido em cabides apropriados. Esta foi uma inovação de visual merchandising que gerou maior percepção de valor da peça. Estratégia que foi adotada por todas as marcas de biquíni dali em diante. Desse modo, o biquíni deixa de ser uma peça secundária dentro da disposição da loja e passa a ser o produto principal.

Outro modelo que ficou marcado por evidenciar as nádegas femininas foi o modelo Fio Dental fabricado em 1984 também pela Bumbum Ipanema. Cidinho conta que se inspirou em uma temporada em Ibiza (Espanha) após achar estranho o modelo que as mulheres de lá estavam usando. Segundo ele, era "uma corda em formato de T" (entrevista em 16 de janeiro de 2014). Chegando ao Brasil, ele adaptou o modelo acrescentando curvas para esconder o cóccix. Surgia então o biquíni batizado de Fio Dental: modelo que exigia um corpo impecável, esculpido em academia.

Foi em resposta aos biquínis projetados pelo Cidinho que surge a marca Salinas

\footnotetext{
${ }^{71}$ Monique Evans começou sua carreira de modelo aos 14 anos, aos 18 já era famosa. Foi capa de diversas revistas femininas e masculinas como a Playboy em 1985, 1986 e 1993). Participou de telenovelas e foi apresentadora de programas de entretenimento. Fontes: jornal o Globo https:/extra.globo.com/famosos/ensaio-sensual/relembre-15-capas-memoraveis-de-monique-evansque-completa-60-anos-19644787.html e jornal Extra: http://www.terra.com.br/istoegente/63/reportagem/rep_monique_evans.htm Acesso em 17 de fevereiro de 2019 .
} 
fundada por Jacqueline de Biase, em 1982. Segundo a empresária, estilista e modelo de prova das suas criações, a marca surgiu como uma alternativa para as moças que não desejavam expor demais seus corpos: "para quem não adotou a moda do AsaDelta e Fio Dental e que acabou ficando órfã de opções nesse período" , conforme entrevista concedida em 22 de janeiro de 2014:

Chegou nos anos 80, (o biquíni) acabou diminuindo muito, virou fio dental e não tinha mais para onde diminuir (...) você querer se manifestar através do seu corpo, mostrar mais que ele é meu (o corpo), eu faço o que quiser com ele, eu tenho a liberdade de fazer o que quiser com ele. Então esse biquíni foi acompanhando isso, essa mudança da mulher até os anos $80 \ldots$ ele diminuiu, virou um fio dental, muito pequeno, até que não tinha mais como evoluir. Nessa época o culto ao corpo começou com as mulheres que faziam ginástica, bodybuilding e iam mexendo no seu corpo (...) você não ouvia falar em ginástica, ouvia falar ali na praia, era uma coisa de se exercitar, de saúde e não de modelar o corpo, vamos dizer assim, né, como é a musculação. Quando a mulher foi tomando noção que ela podia mexer no corpo dela, podia modificar, eu acho que nisso também o biquíni foi acompanhando. Aí até os anos 80 o biquíni diminui muito até que chegou uma hora que ele deu uma parada - não da mais pra diminuir (...), tem pessoas que continuaram com esse biquíni pequeno, esse fio dental, daí você começa a dividir em tribos, e foi aí também que a Salinas surgiu, a gente começou a fazer um biquíni nos anos 80 que já buscava um conforto porque o biquíni estava tão pequeno, tão pequeno, mínimo exageradamente - chegando a beirar o vulgar que a Salinas surgiu nessa época dizendo não, peraí, a gente quer um biquíni normal, que vista sem apertar, com conforto, sem ficar exibindo o corpo, ninguém esta aqui para ficar se mostrando, chega, era um exagero o que estava acontecendo, então isso começou a dividir opiniões e as tribos foram se formando, não era todo mundo que usava o fio dental, aí a indústria da moda, que não era muito grande de biquíni na época, começou a se dividir também, a fazer as tribos - os estilos de cada um, mais segmentado, para poder atender quem era da minha tribo, do meu estilo. Enfim, essas mudanças todas tem muito a ver com o comportamento, com o corpo, eu consegui vivenciar essa época desde o início e acompanhar essas mudanças desde que eram bem ligadas ao comportamento (OLIVEIRA, 2014, p.82).

A moda praia e a moda de academia - fitness, sempre andaram juntas. Primeiramente, porque os maquinários e os materiais são os mesmos ou similares, depois devido a sazonalidade do mercado que contribui para que as marcas adotem as duas linhas para não perderem lucratividade nas baixas estações. A marca Rygy batizada por Regina Aragão surge com uma proposta para atender às adeptas da musculação e da ginástica seguidoras do modelo de beleza da atriz Jane Fonda. A estreia na moda praia veio com o biquíni enroladinho: um short de lycra (nome comercial para fibra sintética composta de elastano) sem forro que era torcido de acordo com o gosto de cada usuária. 
$\mathrm{Na}$ esteira das segmentações de acordo com cada perfil de consumidor, surge a marca Lenny, homônima da fundadora Lenny Niemeyer. Segundo sua fundadora, foi criada por conta da sua dificuldade em encontrar modelos mais clássicos que agradassem as paulistanas. A estilista e empresária recebia muitas encomendas de biquínis ao se mudar para o Rio de Janeiro. Por não conseguir encontrar modelos que a agradassem, resolveu investir em seu próprio biquíni.

A partir daí, passou a confeccionar e fornecer para varejistas de algumas marcas cariocas. Devido às mudanças econômicas causadas pelo então presidente Collor, Lenny decidiu abrir sua própria loja, já que o biquíni era, segundo ela, o primeiro item a ser cortado pelas empresas para quem ela fornecia (OLIVEIRA, 2014, p.83). A marca também ficou famosa fora do Brasil por ter uma modelagem maior e padronagem mais sóbria, abrindo espaço assim para a internacionalização de outras marcas brasileiras.

O convívio entre pessoas de origem socioeconômicas diametralmente opostas se dá em diversas esferas: no esporte, no lazer, no comércio dentre outros. Contudo, cabe ressaltar que o fato da diversidade socioeconômica coexistir na praia, ela não exclui o enorme abismo entre os estratos socioeconômicos no Brasil. Tal abismo influi na diferenciação social que pode ser notada pelos múltiplos signos que compõem o paradoxo da moda no papel de diferenciadora e ao mesmo tempo agregadora de acordo com os valores e influencias de cada grupo.

A classificação e identificação em relação aos locais frequentados na praia depende da observação do corpo um do outro e de seus usos. Isso engloba desde o tom do bronzeamento até os demais acessórios no conjunto do grupo que compõe o ato de ir à praia: dia e horário da semana, tipos de protetores solares - com ou sem base (maquiagem) - marcas de roupas, acessórios de moda, penteados, meios de transporte, consumo na praia (tipo de alimentação, onde compra etc.) e, obviamente as marcas ou ausência da visibilidade delas (biquínis, maiôs e similares). São esses alguns exemplos de demarcadores socioeconômicos que compõem uma hierarquização complexa.

Entende-se que a proposta para uma classificação dentro da área de humanas é um processo que por mais que se proponha critérios e parâmetros, ainda esta inserido dentro de uma lógica da subjetividade. Segundo Everardo Rocha (2006), uma 
classificação trata-se de um projeto exaustivo, devemos pensar em termos singulares de classificação e valor, que são modos de construção, operação e distribuição da identidade social: a classificação é um lugar na estrutura a ser necessariamente preenchido para que o mundo se torne coerente e inteligível aos atores. Esse processo instaura a ordem, a diferença e o significado.

A partir dos anos de 1990, surgem muitas marcas de moda praia que vão se posicionando no mercado de acordo com o público que almejavam. Das entrevistas realizadas com os representantes das marcas mencionadas anteriormente, o discurso sobre as estratégias de marketing para impulsionar o consumo girava em torno da persona que cada uma idealizava como consumidor ideal. Tal imagem viria atribuir valor simbólico ao seu capital, como mostra o trecho da entrevista sobre a existência ou não de um padrão de corpo adotado como referência pelas marcas, conforme salienta a representante da Salinas:

Sim existe, a gente não pode tentar vender pra "Deus e o mundo" né, a gente acaba padronizando mesmo, em uma marca você foca, você tem que focar em uma cliente, em uma certa faixa etária, porque senão, se você abre muito, você perde o estilo, você perde a identidade, então você tem que ter uma identidade forte, você tem que focar em alguma coisa (OLIVEIRA, 2014, p.113)

Tais estratégias são amplamente difundidas pelos responsáveis por promover e manter a "proposta de valor" que deve ser notada pelo consumidor como um diferencial que lhe confere status de acordo com como o indivíduo se afeta e se identifica com as histórias que a marca conta - o "History Telling"72. Falar da cultura de consumo significa falar no plural por se tratar de um fenômeno que não é uniforme com consumidores que também não são. Devido à complexidade que a tríade corpo, cultura e consumo requerem, aqui propomos um entendimento no sentido mais abrangente que transpassa a ideia de identidade e papel social:

\footnotetext{
${ }^{72}$ Apropriando-se do termo do marketing History Telling, ou na tradução livre "contar uma história", definimos nessa tese: como uma construção de narrativa em torno do que se deseja comunicar a fim de promover um produto, marca, pessoa, empresa etc. Essa construção é desenvolvida a partir de processos de design e de metodologias de gestão e estratégias do marketing a fim de impactar o consumidor/cliente com algo que seja relevante para ele. Para tal é necessário pesquisar os valores do público direcionado, o mercado, concorrência etc. Independente da história ser verdadeira ou totalmente fantasiosa, o que importa é a forma como é contada a fim de gerar identificação com seu consumidor. Para uma análise do termo History Telling tal qual usado no marketing ver, por exemplo, Kotler, 2010.
} 
Palavras como identidade, pessoa, caráter, máscara ou papel remetem à ideia de performance ou desempenho executado na vida cotidiana. São termos que indicam questões sociológicas tradicionais, como organização social, poder, interação, grupo, além de uma legião de complexas teorias das ciências sociais. De qualquer forma, a ideia de papel social é uma das mais populares para se pensar a sociedade. É muito empregada pelo senso comum aparecendo em expressões correntes que vão desde as famosas papel de bobo, cumpra seu papel ou papel que me cabe. ROCHA (2006, pg. 44)

Com o aumento da concorrência, as marcas de moda praia foram ficando cada vez mais elaboradas. A inovação não se restringia às matérias-primas que iam surgindo da interação entre os novos designers e representantes do varejo com os representantes da indústria. $\mathrm{Na}$ passarela as marcas também ousavam trazendo modelos internacionais famosas como Naomi Campbell. David Azulay investia em altas produções para desfiles-shows. A Salinas chegou a comprar 50 toneladas de bananas para cenografia de coleção inspirada na Carmem Miranda. A moda praia nacional vai aos poucos ganhando fama internacional na indústria brasileira junto com o café, o futebol e a cachaça.

Quando se trata da internacionalização da moda praia brasileira dentre as diversas complexas questões econômicas, de incentivos e de todo o preparo que esse processo requer, há também uma adaptação dos produtos para aceitação do consumidor de acordo com cada país de destino. Segundo os entrevistados supracitados sobre este quesito, podemos destacar a modelagem como atributo fundamental a ser desenvolvido em conformidade com o que se deseja evidenciar no corpo feminino.

Outro destaque é a forma como o produto é apresentado. Dependendo de cada país, as normas e a legislação para medidas e tamanhos cambiam, sendo este mais um complicador já que nem no próprio mercado interno há um consenso em relação à essas referências. Sobre este tópico trataremos no subcapítulo a seguir. 
2.4

A hegemonia dos modelos de corpos de referência para indústria de moda: norma técnica, normatização, antinorma e/ou resistência

Devido à diversidade de tipos físicos que compõem a população brasileira, somado a visão que cada marca tem em relação ao tipo de mulher que pretende atingir como público consumidor. Ocorre no Brasil um crescente debate sobre as normas que servem de referência para projetar roupas de todos os tipos incluindo a moda praia.

Ao longo do texto a palavra norma aparece em dois contextos entrelaçados: ora para se referir aos limites e proporções de tamanhos para modelagem e confecção desenvolvidos pela $\mathrm{ABNT}^{73}$, ora para se referir aos padrões de referência de corpo e beleza vigentes na cultura globalizada em um ambiente de hiperconexão via (trans)mídia, redes sociais, cinema, publicidade, televisão etc. Ou seja, o padrão massificado dos modelos ideais de beleza. Já a palavra resistência aparece em contraponto à norma (dos padrões positivistas do modelo ideal de beleza/corpo do momento).

A crítica sobre as tabelas de referência de medidas e tamanhos paira sobre o que em geral considera-se padrões engessados ou limitados em relação à quantidade de tipos de corpos que ficam de fora das "normas técnicas" de modelagem industrial. A promessa de investigar, rever e atualizar o modelo é antiga, em 2012 a ABNT (Associação Brasileira de Normas Técnicas) lançou em um guia online de "normas para a confecção de moda praia" ${ }^{74}$ com base em um modelo já utilizado pelo setor. Desde então, apesar da busca pela nova tabela, não foram encontradas atualizações disponíveis para esta pesquisa.

É comum encontrar uma disparidade de tamanhos e proporções de uma marca para outra ou até mesmo dentro da mesma marca. As referencias também diferem em

73 A ABNT (Associação Brasileira de Normas Técnicas) é responsável pelo desenvolvimento de referencial para medidas para o vestuário - a norma NBR 13.377, contudo, a mesma engloba poucas medidas do corpo humano e foi gerada a partir de um consenso entre influentes da cadeia têxtil, e não a partir de estudos antropométricos dos corpos humanos na extensão brasileira.

${ }^{74}$ Link para PDF da ABNT: Guia de normas para a confecção de moda-praia, acesso em 11 de setembro de2013:http://portalmpe.abnt.org.br/bibliotecadearquivos/Biblioteca\%20de\%20Documentos/Guia\%20 Con feccao $\% 20 \mathrm{de} \% 20$ Moda $\% 20$ Praia.pdf 
algumas lojas por numeração $(36,38,40,42)$. Muitas vezes, não ultrapassa a numeração 44, outras adotam o tamanho (PP, P, M, G). De todo modo, de nada vale a numeração/tamanho se cada marca usa suas próprias medidas ao desenvolverem suas bases de modelagem. Com isso, ocorre que muitas vezes a mesma pessoa pode vestir P (pequeno) em uma marca e G (grande) em outra concorrente. O que causa confusão, erros, trocas, medo de consumir por comércio eletrônico etc.

A fim de promover um melhor entendimento sobre as diferenças de tipos de corpos, foram realizados estudos em nível nacional, envolvendo entidades como o SENAI CETIQT e pesquisadores, a partir de um banco de dados com medidas antropométricas feitas com tecnologias para escaneamento tridimensional corporal ${ }^{75}$.

Por um lado, existe a necessidade de ampliar a diversidade das formas que são modelos de referência para confecção de moda - em consonância com a diversidade das formas dos corpos no Brasil. Por outro, existe também a necessidade de padronização, uma vez que, como dito anteriormente, é comum que cada marca desenvolva sua própria base de referência para modelagem.

A partir do levantamento em diversas fontes dos sites do "Sistema S", encontramos informações sobre alguns resultados do estudo antropométrico iniciado em 2005 pelo SENAI CETIQT. Baseado na análise das medidas ${ }^{76}$ de um universo de seis mil mulheres, ampliou-se de cinco para oito as referências para os biótipos femininos brasileiros com maior incidência no "tipo retangular".

Apesar das pesquisas mostrarem que existem muitos outros corpos para além do que a mídia costuma publicitar, a resposta dos atores envolvidos durante a etapa do mestrado não foi consonante com o mote da ideia da diversidade (social, econômica, de corpos e de gênero). Os representantes das marcas líderes participantes das

\footnotetext{
${ }^{75}$ A pesquisadora participou como voluntaria em uma das unidades montada na Semana Design do Jockey Clube do Rio de Janeiro (2013) e teve a medida do seu corpo registradas para o banco de dados que compunha o levantamento.

${ }^{76}$ As tabelas que são utilizadas para modelagem industrial se baseiam em quatro medidas principais (busto, cintura, quadril e quadril alto) e se relacionam também com os biótipos que vemos comumente em publicações de veículos de comunicação, são eles: ampulheta, triângulo, quadrado, oval, triângulo invertido etc. A forma percebida do corpo é comparada com frutas ou formas geométricas e recebe tais nomes. Essas analogias tornam-se convenções muito encontradas na mídia dirigida a produções de looks: composições harmônicas de roupas, sapatos e acessórios de acordo com algum estilo ou tendência de moda e também com o tipo de corpo de cada pessoa (OLIVEIRA, 2012, pg. 54).
} 
entrevistas realizadas entre 2012 e 2014 buscavam um modelo de corpo magro, malhado, esbelto e sem marcas.

À princípio, o discurso evidenciava a preocupação em manter seu público segmentado em um perfil de mulher dentro da norma vigente de beleza. Para compensar este foco excludente, os representantes das marcas diziam considerar a lycra, em geral, um tecido "democrático", pois sua elasticidade alcançaria vários tamanhos, segundo os entrevistados (OLIVEIRA, 2014, p.48).

Ao perguntar se 1) o design de biquíni acompanhava o corpo que ia mudando de acordo com cada época; 2) se havia um padrão predominante de corpo como referência para suas marcas e para qual corpo eles projetavam biquínis (em suas extensões físicas, culturais e sociais) ${ }^{77}$ e por fim: 3 ) se os designers seguiam as normas de modelagem industrial e da ABNT, as respostas foram:

1- Sobre se o corpo vem mudando ao longo do tempo e se o design de biquíni acompanha essas mudanças, todos os designers disseram que sim:

Acompanha, eu sempre falo isso muito, nos anos 60 você tinha um corpo diferente dos anos 70 , dos anos 80 , e isso foi mudando com uma evolução no corpo da mulher.

Nos anos 70 ela tinha um quadril bem largo, ela não tinha essa coisa tanto da alimentação, ela não tinha essa coisa da liberdade também, o biquíni era maior, eu acho que ela cobria mais o corpo, ao longo do tempo foi acontecendo de ir diminuindo esse biquíni, que eu acho que está muito ligado ao comportamento da mulher, que nos anos 60,70 houve uma mudança muito grande, ela foi evoluindo muito a liberdade, a liberdade da mulher com o seu corpo. (Entrevista concedida por Jacqueline de Biase, Salinas em 28 janeiro de 2014. In: Idem p.101).

Acompanha, uma coisa vai acompanhando a outra, nos anos 80 o biquíni era Asa Delta lá em cima - uma coisa puxa a outra, porque aí a mulher começa a malhar mais a perna, as mulheres tinham os corpos mais voltados para usar aquele biquíni Asa Delta, depois a coisa foi mudando por uma coisa estética de época também e na moda-praia essa mudança é muito mais lenta, mas a moda-praia acompanha com certeza, acho que a moda-praia é que mais acompanha essa mudança no corpo. (Entrevista concedida por Thomaz Azulay, Blue Man, em 28 janeiro de 2014. In: Idem p. 102).

Eu acho que a gente acaba acompanhando sim, é claro que o biquíni é uma peça elástica, eu acho que o que muda mais é o comportamento da mulher, mas de qualquer forma, uma mudança importante é por exemplo o tamanho do sutiã, as mulheres hoje tem mais seios grandes porque as que não tinham se "turbinaram" e as mulheres cresceram um pouquinho de tamanho, elas estão mais musculosas, então acaba influenciando com

\footnotetext{
${ }^{77}$ Para não tornar o trabalho repetitivo em relação ao que foi feito no mestrado, caso o leitor se interesse sobre as questões da dissertação, ela se encontra disponível na Biblioteca Central da PUC-Rio e no endereço eletrônico da biblioteca: https:/www.maxwell.vrac.puc-rio.br/28375/28375.PDF.
} 
certeza na modelagem. (Entrevista concedida por Leny Niemayer, em 04 de dezembro de 2013. In: Idem p. 102).

1- As respostas sobre se existiria um padrão de corpo que o designer usaria para projetar seus biquínis, as respostas também foram no sentido da confirmação da busca por uma referência corporal para a marca. (Entrevista concedida por Thomaz Azulay, Blue Man, em 28 de janeiro de 2014):

Existe um padrão predominante das mulheres que; como posso dizer; as satisfeitas com o corpo é a palavra, na verdade não é que a gente quer fazer só para quem tem corpão, é pra quem está seguro com o corpo, se ela estiver segura ótimo, isso é o mais importante - como a praia é um lugar democrático. Mas é claro que sempre há um referencial do que é o imaginário é a mulher a "cocotinha" da praia. (Entrevista concedida por Thomaz Azulay, Blue Man, em 28 de janeiro de 2014).

Sim existe, a gente não pode tentar vender pra "Deus e o mundo" né, a gente acaba padronizando mesmo, em uma marca você foca, você tem que focar em uma cliente, em uma certa faixa etária, porque senão, se você abre muito, você perde o estilo, você perde a identidade, então você tem que ter uma identidade forte, você tem que focar em alguma coisa. (Entrevista concedida por Jacqueline de Biase, Salinas em 14 de maio de 2014).

2- As respostas sobre se os designers seguem alguma norma de modelagem para desenvolver seus biquínis foram quase que unânimes: além das normas não serem seguidas por conta das dificuldades de adequação, cada marca teria desenvolvido suas próprias medidas para base de modelagem. Ou seja, é muito comum no Brasil que as proporções dos biquínis mudem de marca para marca por conta dessa falta de padronização. Outro fator que contribui para a disparidade seria o fato das marcas possuírem suas modelagens em cima de proporções que já foram testadas ao longo dos anos e, portanto, já havia uma identificação com o público.

Para desenvolver suas bases, os designers seguiram o processo de "tentativa e erro". Conforme a fala do Cidinho, ele criou seus modelos a partir do que observava em suas viagens, como foi o caso do modelo Fio Dental. Lenny Niemeyer criou adaptações a partir bases existentes para modelos elegantes e mais comportadas e Jacqueline de Biase desmanchou um biquíni para entender como ele era feito. (OLIVEIRA, 2014, p. 106).

Dentre as várias questões acerca dos corpos e das normas de produção e consumo 
de moda praia, destacam-se também as mudanças ocorridas nos “corpos remodelados extremo" como as próteses de glúteo e mamária de silicone em volumes grandes. Quando pensamos na mulher que nos anos de 1970 usava um modelo de sutiã tomaraque-caia, supomos que ela estaria se sentindo segura no modelo. Provavelmente, por possuir mamas pequenas e/ou sem ptose (caimento natural), uma vez que o modelo sem alças não confere sensação de segurança em uma mama maior e com ptose.

Já para a mulher com mamas implantadas, é comum ver os modelos tomara-quecaia em tamanhos pequenos vestindo mamas grandes, cobrindo somente uma parte pequena área.

Seguindo o raciocínio de que os designers em geral buscam um corpo normatizado para projetar seus biquíni, soube-se que as clientes das marcas pesquisadas $^{78}$ que possuem mamas grandes e naturais têm muito mais dificuldades em encontrar um sutiã de biquíni adequado que as clientes que possuem implantes mamários de silicone. Para as vendedoras e gerentes de biquíni das entrevistas-testes (OLIVEIRA, 2014 p.14) a percepção que elas tinham sobre a quantidade de clientes que possuíam implantes de mama é de chamar a atenção: a maioria respondeu que achava que mais de $80 \%$ das clientes possuíam próteses e que era fácil identificar (quando as próprias clientes não diziam para facilitar na busca de modelo ideal). Em uma das marcas, a percepção foi de que $90 \%$ das clientes teriam implantes mamários.

Ao perguntar aos designers de moda praia se eles buscavam materiais e suportes inovadores na indústria de moda para projetar biquínis voltados para um corpo remodelado, as respostas foram, por um lado, afirmativas, mas por outro, que não acontecia de forma direcionada/intencional para um corpo em específico. Ainda segundo os designers, era comum surgirem oportunidades de inovações a partir de “ problemas" que eles levavam para a indústria têxtil. Eventualmente, tais problemas poderiam resultar em parcerias entre a indústria e instituições da área de ensino. ${ }^{79}$

\footnotetext{
${ }^{78}$ Em entrevistas-testes (em uma imersão preliminar no campo) com mais de 20 vendedoras e cerca de 4 gerentes de lojas de moda praia (Bumbum, Cia Marítima, Salinas e Banco de Areia e Rygy do Shopping Rio Sul em 2012 - texto na íntegra disponível nos anexos da dissertação de mestrado defendida em 2014 pela pesquisadora (OLIVEIRA, 2014, pg.149).

${ }^{79}$ Como é o caso do Instituto SENAI de inovação (ISI) de biotecnologia, transformações químicas, engenharia de processos e fibras do SENAI CETIQT - que possui diversos setores que prestam serviços
} 
Podemos pensar no designer de moda como conciliador na relação entre a indústria e o mercado consumidor, pois o designer pode influenciar no direcionamento da criação de novos materiais, como ocorreu no caso contado por Jacqueline de Biase (entrevistada em 22 de janeiro de 2014) sobre sua dificuldade em encontrar uma lycra que não enrolasse no bumbum. Jacqueline levou seu problema para a indústria e essa parceria resultou no desenvolvimento de diversas gramaturas de Lycras. Atualmente são comercializadas em todo o mercado de moda praia e fitness.

O designer além de comumente participar no desenvolvimento de inovações em parcerias com indústria e educação, possui o papel central de articulador entre o corpo que vai mudando ao longo dos tempos com a imagem que se pretende materializar em produtos, na marca ou em uma coleção temporária. A exemplo disso, temos a modelagem do sutiã de biquíni, que atualmente é maior por conta da tendência do uso de próteses mamárias. Outra inovação que conjuga os interesses da marca com os corpos normatizados são as Lycras fininhas de nome fantasia: "light”. Ao serem costuradas franzidas, dão um efeito de "levanta bumbum" em corpos magros e atléticos:

Os sutiãs estão maiores porque as pessoas estão usando silicone, estão, mas não nesse nível assim de exagero. Então as modelagens estão maiores a gente teve uma época que aumentamos um pouquinho os tamanhos para que não ficasse umas diferenças que nada a ver com a ABNT, completamente fora das regras, porque se a gente tivesse seguido regras era fora do padrão (grifo da pesquisadora). Não sei se nisso, porque no passado todo mundo tinha o peito menorzinho, a maioria das pessoas magras tinha (peito) pequeno, não tinha essa coisa do silicone, todo mundo era meio despeitado, a maioria tinha peito pequenininho, usava sutiã menorzinho e tal. (Entrevista concedida por Jacqueline de Biase, Salinas, 14 de maio de 2014. In: OLIVEIRA, 2014, p. 172)

Ainda sobre as normas para confecção de modelagem de moda praia e se os corpos utilizados pelos designers como modelo de referência deixariam de fora os “ outros corpos", para Lenny Niemeyer a mulher brasileira não tem um biótipo predominante de corpo. Portanto, jamais teremos um padrão tão rigoroso (de modelagem) como, por exemplo, as americanas "que na maioria não tem bumbum e sim muito busto". (Entrevista concedida por Leny Niemayer, em 04 de dezembro de

e consultoria para empresas fazendo interface entre pesquisa, inovação, tecnologia com a indústria. Fonte: https://senaicetiqt.com/inovacao/, acesso em 20 de fevereiro de 2019. 
2013).

Se por um lado toda norma é massificada e reproduzida exaustivamente, por outro, ela acaba por produzir seu movimento antagônico: uma antinorma ou a resistência. Seria então possível aferir que o padrão dominante de beleza dos corpos na cultura carioca (microcosmo) e das suas influências, tais como Estados Unidos e Europa (macrocosmo), coexistem com os modelos da resistência? A resposta é que sim e tais evidências podem ser facilmente encontradas nas campanhas de publicidades, nos veículos de comunicação e na mídia de uma forma geral.

Contudo, também é notório que não há uma igualdade em termos de espaço para que as narrativas em torno dos corpos resistentes possam ter a mesma visibilidade que as dos corpos normatizados. Contraditoriamente, no Brasil existe um altíssimo percentual de mulheres que se encontram fora da norma principal do padrão de beleza: a do peso versus altura.

Seguindo as tabelas que calculam as taxas do índice de gordura corporal (IMC), é maior o número de mulheres que estão com sobrepeso e obesidade, de acordo com o trecho extraído de um relatório da Organização das Nações Unidas publicado pelo jornal O Globo ${ }^{80}$ em 2017:

A obesidade e o sobrepeso vêm aumentando no Brasil assim como em toda a América Latina e Caribe, com um impacto maior nas mulheres e uma tendência de crescimento entre as crianças, aponta relatório (...). De acordo com o levantamento, intitulado "Panorama da Segurança Alimentar e Nutricional na América Latina e Caribe", mais da metade da população brasileira está com sobrepeso e a obesidade já atinge a $20 \%$ das pessoas adultas no país, enquanto $58 \%$ da população latino-americana e caribenha estão com sobrepeso (...). Segundo o documento, elaborado com base em dados da Organização Mundial de Saúde (OMS), o sobrepeso em adultos no Brasil passou de $51,1 \%$ em 2010, para 54,1\% em 2014. A tendência de aumento também foi registrada na avaliação nacional da obesidade. Em 2010, 17,8\% da população era obesa; em 2014, o índice chegou aos 20\%, sendo a maior prevalência entre as mulheres. (GLOBO, 24 de janeiro de 2017).

Diante do exposto, é compreensível que cada vez mais o nicho dos modelos de biquínis maiores dentro de categorias cunhadas como plus size se expanda no Brasil e em todo o mundo. Comumente é possível encontrar em grandes cadeias de varejo - as magazines - setores de produtos de moda direcionados ao público fora da norma das

\footnotetext{
${ }^{80}$ Sobrepeso e obesidade em alta no Brasil, diz ONU. Acesso em 17 de janeiro de 2019, fonte: https://oglobo.globo.com/sociedade/saude/sobrepeso-obesidade-em-alta-no-brasil-diz-onu-20819122
} 
numerações que ficam limitadas a escalas menores de tamanhos.

É preciso destacar que as discussões em torno da maneira como o mercado se apropria das narrativas de resistência - seguindo a lógica de consumo, se dão em diversos níveis, desde como o próprio mercado batiza os termos referentes aos públicos fora do padrão - como é o caso de “plus size” - até como a publicidade erroneamente constrói narrativas que alimentam a exclusão, o preconceito e a “ gordofobia” .

Nesse sentido, em que medida a moda praia que é a moda que mais evidencia o corpo pode ser "desviante" em relação à norma? Até que ponto consegue efetivamente atuar como crítica ou desconstrução da normatividade?

Cabe também saber se a moda praia direcionada aos chamados corpos resistentes não seria apenas mais uma ação mercadológica da indústria visando oferecer aos consumidores uma oferta mais ampliada de escolhas, como forma de ampliar as possibilidades de mercado? Nesse sentido, seria mais um modismo que surge na esteira das reivindicações das lutas pela liberdade individual, por novas formas estéticas identitárias? Tal apropriação (mercantilização) das reinvindicações de uma moda praia para corpos fora da norma não acabaria por acarretar a diminuição do seu potencial crítico, esvaziando as narrativas de resistência desses corpos?

Segundo alunos do curso de design de moda participantes do grupo focal (adiante apresentado no capítulo 3), o ensino não estaria em consonância com as discussões em torno dessas questões, uma vez que "nem todo mundo está pensando na resistência". Isso preocuparia parte dos alunos que buscam pensar a moda de acordo com os motes atuais das discussões que se pulverizam a partir da dinâmica das redes sociais.

Uma alternativa encontrada por algumas marcas para o problema de grades e tamanhos em relação a diversidade e biótipos da mulher brasileira é a opção de deixar a consumidora montar suas combinações na loja: tamanhos intercambiáveis para o corpo que nem sempre segue as mesmas proporções para partes de calcinha e sutiã. Tal alternativa é uma estratégia que potencializa o consumo, uma vez que permite alcançar uma gama maior de clientes seguidoras das propostas de valor contidas no que cada marca representa dentro da hierarquia de consumo. Segundo a diretora de 
criação da Salinas:

(...) a gente pensa assim, ah, essa é pra quem tem pouco peito, a gente vai direcionando um pouco para formar os pares dos biquínis, a gente vende separado também, isso é uma coisa boa da gente criar pensando na parte de cima e na parte de baixo a gente faz um jogo de quatro biquínis e esses quatro biquínis depois podem ser vendidos a parte de cima com um tamanho que quiser, a parte de baixo com o tamanho que quiser, o modelo que quiser e aliás a gente libera, se quiser comprar esse sutiã com esse outro estampado. Isso funciona, isso a gente já fez há muitos anos atrás, com essa coisa do mix e de uns 6 anos pra cá a gente deixa tudo solto, então as pessoas têm mais liberdade, isso já resolve muita coisa, já que a gente tem essa variedade de parte de cima, de parte de baixo, tamanhos e formas, às vezes a pessoa está maior em cima e menor embaixo, ou grande em cima e mais magra em baixo. Ela personaliza seu biquíni. (Entrevista concedida por Jacqueline de Biase, Salinas, 14 de maio de 2014. In: OLIVEIRA, 2014, p. 172).

Outra solução para ampliar os nichos da moda e dos segmentos como o caso da moda praia é a crescente adaptação dos modos de produção em relação às novas formas de consumo. Cada vez mais customizada, individualizada e baseada em produção sob demanda, reduz custos e estoque de produtos que acabam encalhados gerando problemas ambientais e de sustentabilidade econômica.

Tais mudanças estão dentro do que foi chamado de "confecção 4.0" que adiante será apresentada ao leitor dentro de um contexto da revolução ou indústria 4.0 na área da educação e da indústria nacional. No que se refere a discussão até aqui, pode ser que essa nova maneira de consumir seja uma esperança para aqueles que desejam interferir no design e modelagem de suas roupas, a partir das suas próprias medidas com o escaneamento corporal feito em casa e outras tecnologias disruptivas como a realidade aumentada, virtual, impressão tridimensional etc. 


\section{3 \\ A RELAÇÃO ENTRE O ENSINO E A INDÚSTRIA DE MODA NA VISÃO DE PROFESSORES E ALUNOS}

\section{1}

\section{Apresentação do capítulo}

Para se chegar a um entendimento sobre as articulações entre o ensino e a indústria de moda, foi feito um levantamento a partir de informações e dados sobre o ensino de design de moda no Brasil, no contexto do sistema de educação. Sendo assim, esse capítulo traz uma análise do "estado da arte" do ensino e pesquisa em design de moda tendo em vista a produção acadêmica existente. Ao identificar o design de moda como um campo de atuação que abrange diferentes domínios de conhecimento e saberes, propõe-se então que instituições de ensino não somente adotem uma grade curricular cujo conteúdo privilegie a interdisciplinaridade, como também elaborem programas que melhor atendam as demandas do mercado moda praia. Ou seja, as instituições de ensino em design de moda devem estar atentas ao modus operandi característico desse referido mercado a fim de que os alunos possam ampliar suas chances de inserção profissional.

Essa distância identificada entre a realidade das salas de aula e aquela vivenciada na indústria de moda praia aparece igualmente como objeto de denúncia na voz dos atores sociais envolvidos no presente trabalho, enquanto sujeitos cuja relevância é significativa tanto na esfera da educação quanto no mercado.

Foram utilizadas diferentes técnicas contempladas pelas pesquisas qualitativas como entrevistas, questionários e grupo focal. O processo de aproximação dos atores envolveu visitas técnicas a escolas de moda e laboratórios de pesquisa, levantamentos de ofertas de cursos, extensões e capacitações que contemplam a moda praia. Por fim, a pesquisadora narra sua experiência como curriculista de cursos na área de moda em um projeto realizado em Brasília pelo Senai (do Departamento Nacional - DN). O 
projeto de redesenho de currículo incluía a revisão diversos cursos ligados à indústria de moda nos níveis técnico e bacharelado ${ }^{81}$.

Foi então formado um comitê composto por professores e especialistas acadêmicos com objetivo de pensar a realidade do ensino de moda para propor um diálogo que estabelecesse uma articulação que aproximasse os campos do ensino e da indústria. Para responder as questões de pesquisa, esse capítulo foi subdividido da seguinte forma:

No subcapítulo 3.1, o enfoque se deu sobre o panorama do contexto da educação no ensino do design de moda no Brasil e na fundamentação teórica dos autores escolhidos. No 3.2, "a voz de representantes do ensino sobre a relação com a indústria no design de moda praia", a coordenadora do Instituto Rio Moda foi entrevistada sobre o curso voltado para moda praia oferecido em sua escola. No 3.3, utilizou-se a técnica de grupo focal, a pesquisadora compilou as respostas de alunos do design de moda dos cursos de design de moda de duas universidades do Rio de Janeiro para melhor entender a visão deles em relação às questões de pesquisa apresentadas.

No subcapítulo 3.4, pesquisadora narra sua experiência enquanto integrante do corpo de especialistas acadêmicos e professores de design de moda e áreas afins para o processo de redesenho de currículo, com base na metodologia de ensino do SENAI do Departamento Nacional. O capítulo se encerra com a reflexão sobre a percepção dos alunos do curso de design de moda da PUC Rio em relação à relevância do conhecimento adquirido acerca do mercado moda praia, tendo em vista as suas respostas aos questionamentos referentes ao escopo do currículo de ensino da graduação.

\footnotetext{
${ }^{81}$ Para mais detalhes sobre o projeto pedagógico do curso bacharelado em Design com ênfase em Moda (Curso Superior de Design de Moda) acesse o site do SENAI CETIQT. Fonte: https://senaicetiqt.com/wp-content/uploads/2018/03/ppc_design_moda_2017.pdf acesso em março de 2019.
} 


\section{2}

\section{Design de moda, interdisciplinaridade e o contexto da educação}

Segundo Edgar Morin (2013), a ciência moderna, como é posta, foi cada vez mais se associando à técnica, tornando-se tecnociência. Progressivamente, essa configuração foi se difundindo e se introduzindo na sociedade em suas diversas esferas, sociais, políticas, nas empresas, no Estado e nas universidades. A transformação em mão dupla produziu sistemas de disciplinas verticalizadas, enquanto que a ciência tem realidade multidimensional e ambivalente, "assim a ciência é, intrínseca, histórica, sociológica e eticamente, complexa" (2013,p.9).

A fragmentação apontada por Morin é vista também nas falas de autores que buscaram definir aplicações para os usos do termo "design de moda". Segundo Dorotéia Pires (org. 2010) a integração do design na moda foi tardia graças ao rigor da ciência e do método. A moda foi acolhida pelo design somente no século XXI. Até o ano 2000 a oferta de cursos para formar profissionais que "se ocupavam da concepção de produtos de moda, ocorria na perspectiva do estilismo e não do design" (2010, p.13).

A fragmentação dos processos das metodologias de design que controlam o projeto, seria, segundo Dorotéia Pires (2010), destrutiva ao reduzir as capacidades sistêmicas do designer. Os processos cognitivo, criativo, de metodologia científica e projetual são interdependentes. Ou seja, formam um sistema de gestão do conhecimento para o desenvolvimento de projetos.

"Em design, denomina-se desenvolvimento de projetos, sendo esta atividade realizada por meio das etapas de metodologia projetual, aplicando alguma das diferentes técnicas de criatividade". (PIRES, org., 2010, p. 129).

"Definir para dialogar" é o que se buscou para um entendimento sobre o "design de moda", de acordo com o levantamento ${ }^{82}$ acerca de seus usos e definições. Com o

\footnotetext{
${ }^{82}$ Utilizamos o trabalho intitulado Design de moda, olhares diversos organizado por Dorotéia Baduy Pires, editora Estação das Letras, (2010), por ser um livro reúne uma série de artigos de pesquisadores inseridos no contexto do ensino na área. As visões apresentadas pelos autores são plurais, assim como a área do design que faz interface com tantas outras. As falas evidenciam concordâncias e ao mesmo tempo
} 
intuito de situar o leitor, utiliza-se a fala da professora Diva Costa ${ }^{83}$. Segundo a professora, o designer de moda é um profissional que vai pensar em um novo produto com foco em uma produção industrial. Portanto, ele precisaria entender para além de moda e estilo. Ou seja, teria de conhecer muito bem os materiais e os processos para a produção daquele produto. Já o estilista, ele é mais voltado para a criação de uma peça única e não precisaria ter o pensamento industrial:

Muitos estilistas se tornaram os profissionais que são com a experiência e com o tempo. É uma profissão antiga. O designer de moda é algo mais contemporâneo que pode ter surgido com a produção em massa. Antigamente o SENAI CETIQT tinha o curso de Estilismo. Em 2000 abriu a primeira turma do Design de Moda. Hoje o SENAI CETIQT oferece o Bacharelado em Design: ênfase em Moda. (COSTA, 2017).

Entende-se que há, por um lado, um perigo em ficar apenas na superfície das discussões teóricas quando se almeja articular muitos saberes. Por outro, a hiperespecialização verticalizada é igualmente perigosa, uma vez que o aprofundamento em determinada especialidade pode ser uma barreira ao isolar o objeto de outras áreas do saber:

O ser humano nos é revelado em sua complexidade: ser, ao mesmo tempo, totalmente biológico e totalmente cultural. (...). Nossas atividades biológicas mais elementares comer, beber, defecar - estão estreitamente ligadas à normas, proibições, valores, símbolos, mitos, ritos, ou seja, ao que há de mais especificamente cultural; nossas atividades mais culturais - falar, cantar, dançar, amar, meditar - põe em movimento nossos corpos, nossos órgãos; portanto, o cérebro (MORIN, 2001a, p.40)

O domínio que o especialista tem como de sua propriedade acaba o "proibindo" de fazer incursões em outros domínios (MORIN, 2001) causando-lhe cegueira e presunção na defesa da sua área em detrimento das demais. Por acreditar que o conhecimento é a chave para melhorar a vida das pessoas em geral e que a ciência é o caminho que permite a sistematização de informações essenciais para que a inovação

dissonâncias, dependendo do lugar, da visão de mundo e formação dos autores. Utilizamos também o livro organizado por professoras do Departamento de Artes e Design: "Design em situações de EnsinoAprendizagem: 20 anos de pesquisa no laboratório Interdisciplinar de Design/Educação”. Editora Rio Books, 2014.

${ }^{83}$ Diva Lúcia Vieira Costa é professora de diversas disciplinas no curso de Graduação em Moda do SENAI CETIQT, além de também integrar o comitê de curriculistas de cursos técnicos e o Bacharelado em Design com ênfase em Moda, à nível nacional. Ao longo do processo de redesenho de currículo, a pesquisadora pôde realizar um questionário com a professora Diva da Costa, em dezembro de 2017. 
seja possível, buscamos correlacionar os fenômenos com suas relações de reciprocidades:

Trata-se de procurar sempre as relações e inter-retro-ações entre cada fenômeno e seu contexto, as relações de reciprocidade todo/partes: como uma modificação local repercute sobre o todo e como uma modificação do todo repercute sobre as partes. Trata-se, ao mesmo tempo, de reconhecer a unidade dentro do diverso, o diverso dentro da unidade (...). Para pensar localizadamente, é preciso pensar globalmente, como para pensar globalmente é preciso pensar localizadamente (MORIN, 2001, p.25).

Nos últimos anos assistimos a crescente oferta nos cursos de moda em todo país. Em 2010 foi feito um levantamento do número de teses e dissertações sobre a Moda no Brasil publicado na revista YARA (Revista de Moda, Cultura e Arte) pela pesquisadora Maria Cláudia Bonadio ${ }^{84}$ (BONADIO, 2010, p.52-79) e foram identificados 533 trabalhos na época. Em 6 anos o número dobrou para 1100, de acordo com a ABEPEM (Associação Brasileira de Estudos e Pesquisa em Moda), com estimativa para até o ano de 2017.

$\mathrm{Na}$ área da educação, é recente o interesse de trazer a Moda para dentro do contexto das discussões formais, antes as pesquisas eram endereçadas às áreas de economia (4\%) e administração (17\%), seguido por comunicação (13\%) e design (10\%), segundo o economista Enrico Cietta, autor de "A economia da Moda" (2017, p.47). A produção de pesquisas de Moda é geralmente pulverizada entre diferentes linhas de pesquisa e orientadores. Em outras palavras, consideramos que a Moda está tendo uma atenção crescente por parte do mundo acadêmico brasileiro, e isso se reflete na oferta de formação. Contudo, a Moda ainda está muito ligada às funções técnicosprodutivas, (engenharia de produção) ou funções estéticas/estilísticas no contexto do design e da comunicação, deixando um pouco de lado as questões ligadas à economia, empreendedorismo e uma visão orientada para a gestão (CIETTA, 2017, p.181).

\footnotetext{
84 Maria Claudia Bonadio possui doutorado em História pela Universidade Estadual de Campinas (2005), realizou estágio pós-doutoral no Museu Paulista da Universidade de São Paulo (2014). É professora adjunta da Universidade Federal de Juiz de Fora atuando no Bacharelado Interdisciplinar em Arte e Design, no curso de Moda e no Programa de Pós-Graduação em Artes, Cultura e Linguagens, do qual é coordenadora desde agosto de 2018. A professora é autora de diversos livros. Fonte: Plataforma Lattes: http://lattes.cnpq.br/3920027222039096, acesso em 17 de fevereiro de 2019.
} 
No cenário das escolas de design, a organização de um ensino verticalizado continua sendo a matriz utilizada na estruturação dos currículos e ementas ${ }^{85}$. Tal estrutura educacional, essencialmente positivista vai de encontro com a percepção da realidade de como operam mercado e indústria. O setor da moda opera de forma interconectada em relação às funções operacionais, de estratégia, criação, produção e demais etapas produtivas, de acordo com as falas de alunos e professores que serão apresentadas.

Discute-se a necessidade em dar mais atenção à transversalidade entre as áreas de conhecimento. Ou seja, não somente introduzir disciplinas de outras áreas em uma ementa. Ao invés de ensinar marketing ao designer de moda, ensinar o designer de moda a projetar do ponto de vista da área do marketing: dos processos e fases da cadeia produtiva, do mercado, da composição de oferta etc.

Segundo as falas que se verá adiante - professores e alunos dos cursos de design de moda que participaram dessa pesquisa - o currículo dos cursos de moda deveria ser sempre atualizado no sentido de criar uma relação entre disciplinas que deveriam ser atravessadas por um eixo comum, transversalmente, abrindo espaço para um enfoque maior na criação, experimentação e pesquisa. Durante a imersão no campo, a pesquisadora notou que em geral os currículos dos cursos de moda se encontravam fragmentados.

A falta de linearidade no ensino é também resultado de uma certa dificuldade em realizar trabalhos utilizando os laboratórios dentro de universidades de forma integrada. Outro obstáculo, decorrente de um ensino fragmentado é a de se conseguir iniciar projetos do começo até o final, pois estes parariam em alguma etapa do processo, dependendo da capacidade de realização e de cada fase de maturidade dos alunos em relação a duração das disciplinas.

\footnotetext{
${ }^{85}$ Não pretendemos aqui fazer uma extensa avaliação dos currículos dos cursos de moda, nem trazer as discussões sobre as diferenças entre as siglas e conteúdo dos cursos ou sobre as mudanças e atualizações feitas constantemente por entidades reguladoras como o MEC. Os dados da educação foram levantados até o ano de 2017 e podem sofrer modificações, de acordo com as mudanças no cenário político e novas reformas da educação.
} 
Os cursos de graduação em moda ${ }^{86}$ na última década foram absorvendo o conceito da palavra "design" dando um sentido mais abrangente a atividade do projetista que atua na área. A ênfase no design como processo que engloba disciplinas não só do estilismo, estética, arte, história e comunicação, mas também gestão, tecnologias emergentes que fazem interface com as engenharias e administração, permite deduzir algumas tendências estruturais mais alinhadas às demandas de um ensino que dialoga com a indústria.

De um total de 179 cursos a prevalência da palavra design está em $99 \%$ dos casos dos cursos tecnológicos e $62 \%$ dos de bacharelado, conforme mostra a tabela abaixo:

\begin{tabular}{|l|l|l|l|}
\hline \multicolumn{1}{|c|}{ Nome } & Tecnológico & Bacharelado & Total \\
\hline Design de Moda & 125 & 27 & 152 \\
\hline Design de Moda - Estilismo & & 1 & 1 \\
\hline Design de Moda - Modelagem & & 1 & 1 \\
\hline Design de Moda e Vestuário & & 1 & 1 \\
\hline $\begin{array}{l}\text { Moda e Design } \\
\text { Moda, Design e Estilismo }\end{array}$ & 1 & 1 & 1 \\
\hline Moda & & 1 & 1 \\
\hline $\begin{array}{l}\text { Negócios da Moda } \\
\text { Desenho Industrial - Design de } \\
\text { Moda }\end{array}$ & & 18 & 19 \\
\hline \multicolumn{1}{|c|}{ Total } & 126 & 1 & 1 \\
\hline
\end{tabular}

Quadro 1: Fonte E-mec / IES, Graduação no Brasil, 2016.

Referimo-nos ao design no contexto do ensino e do trabalho reconhecendo-o como um campo que tem por vocação ser interdisciplinar. A prática do design demanda, além de conhecimentos técnicos, considerações sobre o universo dos usuários em contato com seus produtos e serviços. Neste sentido, diversos conhecimentos integrados podem ser explorados simultaneamente durante o processo projetual de diferentes campos: psicologia, estética, antropologia, ergonomia, marketing, informática, economia, semiótica etc.

\footnotetext{
${ }^{86} \mathrm{Na}$ moda, o total de cursos de graduação oferecidos no Brasil era de 179 (incluindo 126 no nível tecnológico e 53 bacharelados). No Rio de Janeiro são 6 tecnológicos, com 1 EAD (educação a distância) e 2 bacharelados totalizando 8 cursos (CIETTA, 2017, p.44).
} 
Essa natureza diversa, em constante contato com múltiplas disciplinas, torna o campo do Design condizente com uma abordagem interdisciplinar. O termo "interdisciplinaridade", não possui um sentido epistemológico definitivo, ou fechado, pois carrega uma série de enunciados dotados de diversas acepções e relações, tendo sido construído desde o surgimento das discussões em torno de diferentes formas de pesquisar, ensinar e traçar diálogos com os saberes das diversas ciências (MORIN, 2001).

A busca constante por uma revisão das formas de ensino compatíveis com as realidades que vão surgindo nas novas formas de comunicação, tecnologias e maneiras de organização compõe um repertório de uma abordagem complexa. Ou seja, observando o conjunto de saberes como um todo em constante movimento e em direção oposta à fragmentação (e verticalização) dos saberes. De acordo com Rita Couto: ${ }^{87}$

A interdisciplinaridade pressupõe novos questionamentos, novas buscas, transformação da própria realidade. Implica uma mudança de atitude, que possibilita o conhecimento, por parte do indivíduo, dos limites de seu saber para poder acolher contribuições de outras disciplinas. Interdisciplinaridade deve ser, pois, entendida antes de tudo, como atitude, pautada pelo rompimento com a postura positivista de fragmentação, visando a compreensão mais ampla da realidade. Através dessa postura é que ocorre a interação efetiva, sinônimo do interdisciplinar. (COUTO, 1997)

A atividade do designer integra ações, interage, faz mediação. É interdisciplinar por transitar entre as áreas que fazem 'fronteira' com sociologia, antropologia, psicologia, arte etc. O Design intensifica a reflexão sobre a educação, pesquisa e desenvolvimento que caracteriza uma cadeia simultânea, pois teoria e prática se auto alimentam, uma vez que não existe uma ordem verticalizada ou a sobreposição de uma pela outra. Dentre as classificações de tipos de interdisciplinaridade, podemos também recorrer a SOMMERMAN (2008) ao pensar no designer como "conciliador" entre cultura e projeto:

A interdisciplinaridade forte (ou centrípeta) aparecerá quando o predominante não for a transferencia de métodos, mas sim de conceitos, e quando cada especialista não procurar

\footnotetext{
${ }^{87}$ A professora Dra. Rita Couto que pertence ao Departamento de Artes e Design da PUC-Rio é autora de diversos textos sobre desiogn e interdisciplinaridade, dentre eles destacamos "Reflexões sobre a questão da interdisciplinaridade” publicado no livro Formas do Design em 2014 (p. 85).
} 
apenas 'instruir os outros, mas também receber instrução' e 'em vez de uma série de monólogos justapostos' (...) requer o favorecimento das trocas intersubjetivas dos diferentes especialistas, onde cada um reconhece a si mesmo e nos outros não só saberes teóricos, mas os saberes práticos e os saberes existenciais (SOMMERMAN, 2008, p.63).

O pensador da "complexidade" Edgar Morin, (2013) articula ordem, desordem e organização com a premissa de que devemos pensar o projeto abarcando os fenômenos sociais, humanos e naturais que compõem partes de um 'todo interdependente.' Dentro da complexidade sugerida pelo autor podemos pensar as relações da moda em suas extensões e influência em cadeia, a partir da experiência do projetar em sua correspondência com os fenômenos das relações humanas. Podemos também pensar na integração da atividade projetual do designer de moda desde a etapa do ensino até o mundo do trabalho, de forma transversal.

Para se chegar a um melhor entendimento sobre as articulações entre ensino e indústria, no caso da moda buscamos ouvir a voz de professores e alunos, de acordo com os critérios que serão apresentados no próximo item deste capítulo.

\section{3}

A voz dos representantes do ensino sobre a relação com a indústria no caso da moda praia

Para essa etapa da pesquisa buscou-se ouvir a voz de representantes da educação com atuação no ensino de moda de diversas escolas do Brasil. Contudo, o Rio de Janeiro concentrou grande parte das escolas e profissionais por diversos motivos relacionados à própria especificidade do caso da moda praia. Seguindo a lógica de que a cidade é a maior produtora do setor ao concentrar um grande número de marcas devido a sua forte cultura do corpo e de praia, o Rio de Janeiro também concentra o maior número de cursos voltados para o segmento.

Embora maior parte da pesquisa tenha se concentrado no Rio de Janeiro, fez-se necessário também o deslocamento para a capital de São Paulo e Brasília a fim de viabilizar etapas do campo. Do levantamento realizado podemos destacar o IED, Instituto Europeu de design do Rio de Janeiro, por ele oferecer um curso mais extenso 
e totalmente voltado para a moda praia, geralmente oferecido duas vezes ao ano. Contudo, ainda é um curso recente na Instituição. Pelo mesmo motivo, a escola de cursos livres de moda Instituto Rio Moda (IRM) foi incluída, pois oferece mini cursos ou workshops.

Os cursos oferecidos pelo SENAC (Serviço Nacional de Aprendizagem Comercial) e pela FIRJAN (Federação da Indústria do Rio de Janeiro) também aparecem no contexto do ensino da moda praia esporadicamente. Contudo, por se tratar de cursos sem uma periodicidade, feitos sob encomenda para atender a agenda do comércio e indústria, não foi possível colher muita informação a respeito.

A pesquisadora também fez 2 estágios em docência na graduação em turmas compostas por alunos de várias habilitações dentro do Design, com ênfase na busca por turmas com a maioria cursando Design de Moda no Departamento de Artes \& Design da PUC-Rio. A instituição destaca-se por oferecer uma gama grande de disciplinas eletivas e optativas e pela possibilidade de dupla diplomação. O curso de Design possui 4 saídas: Projeto de Produto, Comunicação Visual, Design de Moda e Mídia Digital.

A imersão no campo no SENAI CETIQT foi de suma importância nesta pesquisa, não só por ser uma instituição de referência em educação na área de moda, mas também pela posição da pesquisadora devido aos projetos realizados durante sua participação no redesenho de currículo dos cursos de moda a nível nacional. A instituição criada para atender a demanda direta da própria cadeia da em 1949 visa fazer interface entre educação e indústria, buscando inovar em termos de estrutura física industrial para situações de aprendizagem e de metodologia de ensino.

O acompanhamento das iniciativas de difusão do conhecimento de moda praia foi realizado também através do uso de tecnologias, como os aplicativos e redes sociais. Usando o Instagram, o Instituto Rio Moda realizou a divulgação de uma série de cursos rápidos voltados para a moda praia. A seguir a imagem da peça de divulgação para dar ao leitor o tom de como os cursos são comumente oferecidos/comercializados. A ideia é oferecer uma capacitação em um espaço de troca de experiências e contatos (networking) para quem deseja empreender no segmento. 


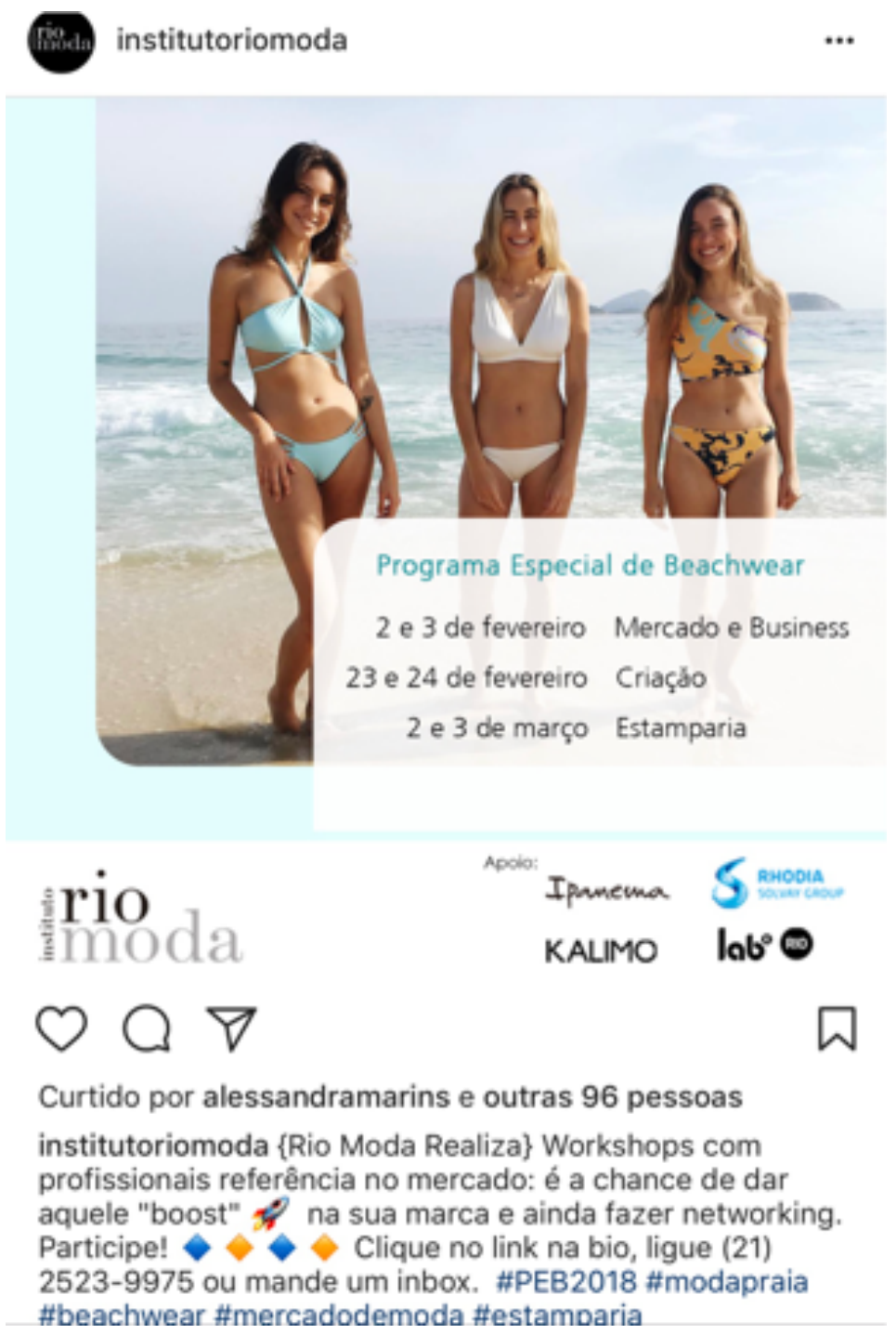

Figura 5: Retirada (print) do Instagram "Workshop com profissionais referência no mercado: é a chance de dar aquele "boost" na sua marca e fazer networking".

A chamada para divulgação intitulada "programa Especial de Beachwear" aconteceria em 2 dias (sexta e sábado) em 3 módulos: Mercado e Business, Criação e Estamparia. Os cursos ocorreram na "Casa Ipanema", uma casa patrocinada pela marca de sandálias homônima, no bairro de Ipanema, nos meses de fevereiro e março de 2018. A coordenadora do Instituto, Alessandra Marins respondeu algumas questões dessa pesquisa. Em um ambiente com aproximadamente 30 pessoas entre alunos, organizadores e manequins espalhados com tecidos, a cena era de concentração nos processos de design: desenhos, cortes de tecidos, modelagem e costura. 
Ao ser questionada sobre como vê a oferta de cursos no segmento de moda praia a partir de iniciativas representativas de aproximação entre o ensino e a indústria, a coordenadora do Instituto diz: "só encontra alguma coisa porque está muito antenada". Segundo Alessandra, isso somente é possível porque suas atividades não se restringem à área de educação, uma vez que trabalha também no mercado de moda como estilista. Esclarece, portanto, que "sente falta desse tipo de capacitação".

Alessandra explica que seus cursos são livres, sem pré-requisito para inscrição. Os alunos geralmente já estão no mercado ou são novos empreendedores. No seu entendimento, são, por conseguinte, participantes. Já os professores assumem a posição de 'facilitadores'. A entrevistada cita o SEBRAE, o SENAC e a FIRJAN como principais meios para promoção dos conhecimentos do segmento de moda praia. Entretanto, não há uma continuidade na agenda das entidades citadas: são cursos pontuais dentro de eventos determinados como a Semana de Moda do Rio ou por algum outro motivo sem uma periodicidade fixa.

Por sua expertise no tema, ela acabou se tornando também consultora do SEBRAE quando eles oferecem cursos sobre o assunto. Segundo Alessandra, a demanda por capacitações na área é tão grande e geral, que $70 \%$ das pessoas inscritas no seu curso estariam vindo de fora da cidade do Rio de Janeiro.

No que concerne à articulação entre atores da indústria e da educação visando uma interação maior entre esses dois campos, Alessandra destaca o perfil profissional. Precisamente, quais as capacidades e competências requeridas para ocupar as funções existentes. Alessandra declara haver no Instituto uma preocupação com a inserção no mercado de trabalho. Nesse contexto, destaca o papel da associação criada para auxiliar empresas e profissionais na busca por posições/empregos:

Geralmente as empresas buscam através do site ABP moda o perfil desejado. A busca maior é de empresários por mão de obra técnica qualificada: tem muita indústria como em Cabo Frio (RJ), precisando de estilista, o workshopp é também uma oportunidade de fazer network.

Quando indagada sobre qual o diferencial que torna a moda praia brasileira um exemplo bem-sucedido da indústria nacional (benchmark) no mercado global, Alessandra diz não saber afirmar se tal afirmação pode ser comprovada, não sabe dizer 
se por números somos "bem-sucedidos". Segundo ela, existem muitas marcas pouco conhecidas no Brasil que estão desfilando em Miami no evento de moda praia "Miami Fashion Week", mas não sabe qual o retorno as marcas conseguem obter com o investimento.

Quando a pergunta foi direcionada ao design, se ela vê um diferencial no biquíni brasileiro, Alessandra respondeu que "não mais": nos anos 1980 existia um apelo pelos tamanhos menores, facilmente identificados no exterior, contudo, hoje não há diferença. Em termos de estamparia, há segmentação de mercado, mas ela não vê uma identidade exclusivamente brasileira. Diz que o diferencial então seria a criatividade e cita o Rio como expert no assunto: "ninguém faz tão bem como no Rio".

Perguntamos se seria pela forte cultura de praia, ela concorda e acrescenta: "Não há ninguém que traduza tão bem a alegria, a juventude, gente bonita, bronzeada". Alessandra cita a cidade de Cabo Frio no interior do Rio de Janeiro como o maior produtor de moda praia no Brasil:

\begin{abstract}
Nova Friburgo está começando a investir na MODA PRAIA para diversificar, são fortes em moda íntima que usa o mesmo maquinário. O SEBRAE e o SENAC fazem esporadicamente capacitações "fechadas" exclusivas para a indústria - são geralmente mais técnicas (entrevista em março de 2018 durante o curso de moda praia na Casa Ipanema).
\end{abstract}

Já com relação às perguntas sobre o quão abrangente é o programa dos cursos existentes - se são completos, se contemplam desde o conceito/história até a parte de projeto/modelagem - a sua resposta foi negativa. Segundo a entrevistada "não existe curso que contemple de A à Z", até por uma questão de sustentabilidade dos cursos, pois existe uma logística. Outro problema na visão da coordenadora seria a questão do espaço físico. Nem sempre a estrutura "pesada" - a exemplo dos maquinários - pode ser levada para compor salas de cursos:

O ensino no segmento encontra-se fragmentado, os interessados no tema precisam buscar informações em diversos lugares diferentes e nem sempre ofertam os mesmos conteúdos (entrevista em março de 2018 durante o curso de moda praia na Casa Ipanema). 
O curso de moda praia oferecido pelo IED Rio, localizado no Cassino da Urca, foi o mais extenso e completo encontrado pela pesquisadora. A despeito de inúmeras visitas ao local, não foi possível estabelecer um contato direto com professores ou coordenação para agendamento de entrevista ou envio de questionário. As informações obtidas sobre o curso foram passadas via e-mail e presencialmente- com objetivo comercial de divulgar e captar alunos.

O curso do IED é oferecido quinzenalmente em dois dias (sexta e sábado), durante aproximadamente 3 meses, com carga horária de 60 horas-aula. $\mathrm{O}$ formato do curso é panorâmico: abrange a parte de projeto, desenvolvimento de coleções, desenho, croqui etc., até a "estruturação de uma marca" que envolve aspectos do marketing e administração. Os alunos do curso desenvolvem um mix de produtos para passarela a ser apresentado no final do curso com um desfile.

Como não pudemos encontrar ofertas de cursos livres sobre moda praia nas instituições PUC-Rio e SENAI CETIQT, ${ }^{88}$ justamente as duas escolas que oferecem cursos superiores em Design de Moda, buscou-se então cursos de extensão similares, dentro da área de moda, para desenvolvimento de análises comparativas. Somente no IED, IRM e na FIRJAN há oferta de cursos específicos de moda praia, mas, como dito anteriormente, sem um calendário fixo ou continuidade.

\footnotetext{
${ }^{88}$ Ressalva: após conclusão e defesa desta tese, soube-se que o SENAI CETIQT abriu um curso de moda praia que não consta aqui por ele ter sido promovido na data da defesa, quando a pesquisadora já havia terminado a coleta de informações. Não se sabe se a iniciativa foi influenciada também por sugestão da pesquisadora durante seu trabalho na referida instituição. Por via de relatórios de pesquisas prospectivas de mercado, o desenvolvimento de um curso de moda praia foi fortemente recomendado, naquela altura.
} 


\begin{tabular}{|l|l|l|r|}
\hline Escola & Carga horária & Custo total & Hora / aula \\
\hline IED & $60 \mathrm{hs}$ & BRL 3.850 & $\mathbf{6 4 , 1 6}$ \\
\hline IRM & $12 \mathrm{hs}$ & BRL 550 & $\mathbf{4 5 , 8 3}$ \\
\hline PUC-Rio (CCE) & $40 \mathrm{hs}$ & BRL 1.458 & $\mathbf{3 6 , 4 5}$ \\
\hline SENAI CETIQT & $60 \mathrm{hs}$ & BRL 1.500 & $\mathbf{2 5 , 0 0}$ \\
\hline FIRJAN & $8 \mathrm{hs}$ & BRL 150 & $\mathbf{1 8 , 0 0}$ \\
\hline ESCA $^{*}$ & $96 \mathrm{hs}$ & BRL 780 & $\mathbf{8 , 1 2}$ \\
\hline
\end{tabular}

Quadro 2: Tabela de valores dos cursos por hora/aula específicos de moda praia no Brasil/ Rio de Janeiro. Levantamento realizado entre março e abril de 2018. De acordo com um acompanhamento/ atualização os valores apresentados na tabela podem ser reajustados sem critérios específicos como é o caso da escola não cadastrada pelo MEC, ESCA* que em 2019 teve um reajuste passando a ofertar o mesmo curso x mesma carga horária por $\mathrm{R} \$ 2.065 * *$ reais (mais de $250 \%$ de aumento).

De acordo com o quadro, a relação entre carga horária e o custo dos cursos varia muito. Os mais técnicos, voltados para a qualificação da mão de obra que atua na indústria são exponencialmente mais acessíveis em comparação aos que tratam de questões da cultura, desenvolvimento de produtos etc. Não entramos no conteúdo de cada curso, uma vez que, nem todos abrem os planos de aulas. Ainda assim cabe enfatizar que foi possível o quão diferem entre si em termos de formato, ênfase, conteúdo, duração etc.

O mundo vive constantes transformações econômicas e políticas que influenciam no modo de produção trazendo novas demandas, percepções, visões e valores. Visando entender as expectativas dos alunos com relação ao ensino, mercado de trabalho e seus anseios sobre o futuro profissional, fizemos uma seleção com a análise dos conteúdos das suas falas para relacionar com os objetivos da pesquisa.

\section{4}

\section{O ensino de moda na visão dos alunos}

Para se chegar a um melhor entendimento da visão dos alunos sobre o ensino do design de moda, um dos instrumentos ao qual a pesquisadora teve acesso foi um grupo focal realizado durante a fase de imersão no campo em instituição aqui identificada como "ESCOLA M". Em respeito ao sigilo do nome da escola e para resguardar seus interesses, foram mantidos em confidencialidade também os nomes de cada campus. 
Optou-se pela restrição de sua divulgação por compreender que o acesso a determinadas informações em razão da confiança que a pesquisadora teve, não deveria extrapolar o que é de interesse e benefício da coletividade, sem com este trazer nenhum tipo de dano a instituição.

A pesquisadora participou como co-organizadora na atividade conduzida por um antropólogo e pesquisador, coordenador de diversos projetos de educação/moda de ESCOLA M. Em respeito ao sigilo dos nomes dos participantes também restringimos a sua divulgação substituindo os nomes por siglas quadro 3 .

A análise dos discursos e as conclusões da pesquisadora sobre determinadas falas relevantes ao tema deste trabalho foram agrupadas, de acordo com as questões de pesquisa. A dinâmica ocorreu a partir de perguntas e respostas e da interação do grupo sobre os diversos aspectos no que tange a complexidade da cadeia de moda, do mercado de trabalho, da visão dos alunos sobre as demandas da indústria em relação ao que é oferecido no ensino em geral e, especificamente, na instituição referida.

O antropólogo conduziu a dinâmica que foi delineada com base nos métodos e técnicas utilizados por ele. A pesquisadora, enquanto observadora, pôde registrar em áudio, transcrever e documentar em um relatório a experiência com o grupo. A amostragem do grupo variou entre 8 a 12 pessoas, amostra homogênea (alunos do $4^{\circ}$ semestre do curso de moda) e heterogênea (em termos de inserção profissional).

A técnica escolhida foi de Associação Livre do assunto referente ao tema e observação participante. A situação apresentada foi o contexto da moda nos cursos da ESCOLA M. A justificativa para escolha metodológica foi que nenhuma das outras geraria resultados para a saída que se buscava.

Houve um período prévio de gerenciamento de ações: a escolha dos alunos indicados (seguindo critérios e que fossem "engajados e participativos" - com indicação do coordenador do curso), contato com alunos, agendamento, envio de convite, organização da reserva de salas e equipamentos, pausa para lanche e café, crachás, certificados etc. Foram feitos dois grupos focais: em um bairro de classe média 
alta (A) e em uma região menos desenvolvida economicamente (B), ${ }^{89}$ tendo por base recomendações de pesquisas prévias da mesma instituição, que apontaram, muita diversidade entre os grupos de alunos de cada campus.

Sabe-se a cidade como o Rio de Janeiro possui dimensões de metrópole cuja a distribuição de renda, especificidades ligadas a formação cultural, nível de escolaridade e demais questões demográficas são marcadas por diferenças muito extremas. A proposta da técnica empregada, de uma escuta que permita dar representatividade e voz a um determinado grupo deveria contemplar as especificidades das duas unidades participantes.

De acordo com a pesquisa realizada em 2010, o IBGE divulgou o XII Censo Demográfico, que mediu a população brasileira e suas características em termos socioeconômicos. A Média de Rendimento nominal médio é extremamente diferente entre os moradores dos bairros A e B (exceto áreas de comunidades pobres). O Censo é realizado de 10 em 10 anos, sendo o próximo apenas em 2020, como mostra a tabela a seguir.

\begin{tabular}{|l|l|l|}
\hline Ranking & Bairro & Total \\
\hline 10 & Lagoa & 8.286 \\
\hline 20 & Joá & 7.891 \\
\hline 30 & São Conrado & 6.902 \\
\hline 40 & Leblon & 6.845 \\
\hline 50 & ESCOLA M /A & 6.835 \\
\hline 60 & Ipanema & 6.533 \\
\hline 70 & Jardim Botânico & 5.811 \\
\hline 100 & Humaitá & 4.856 \\
\hline
\end{tabular}

${ }^{89}$ O grupo focal A foi realizado dia 27 de julho de 2017, teve como pano de fundo as mesmas questões levantadas no grupo focal realizado no campus B. 


\begin{tabular}{|l|l|l|}
\hline 110 & Flamengo & 4.662 \\
\hline 120 & Laranjeiras & 4.574 \\
\hline 130 & Leme & 4.388 \\
\hline 140 & Botafogo & 4.269 \\
\hline 460 & ESCOLA M / B & 1.870 \\
\hline 470 & Centro & 1.818 \\
\hline 480 & Maria da Graça & 1.783 \\
\hline 490 & Taquara & 1.769 \\
\hline 1580 & Manguinhos & 699 \\
\hline 1590 & Acari & 686 \\
\hline 1600 & Grumari & 571 \\
\hline
\end{tabular}

Quadro 3: Ranking do Censo com dimensionamento demográfico por região, fonte: https://censo2010.ibge.gov.br/ acesso em 17 de janeiro de 2018 .

As unidades de ensino, apesar de pertencerem a mesma instituição são muito diferentes em termos de estrutura física, sendo a mais antiga, B, mais ampla e que concentra plantas de Fibras Químicas, Não-tecidos, Tecnologia 3D, Manufatura Avançada, Inovação, Tecelagem, Malharia, Confecção e Fiação, de acordo com a instituição. O campus também conta com uma rede integrada de laboratórios físicos, químicos, colorimétricos, flamabilidade, toxicidade e microbiológico, de física, química, estamparia, tinturaria e lavanderia.

Já o campus A, possui uma área bem menor com limitações em termos de estrutura física, embora a escola esteja localizada em um endereço de alto valor imobiliário, dentro de um conjunto de edifícios luxuosos, como será evidenciado nas falas do alunos participantes do grupo focal.

A análise de resultados ocorreu partindo da coleta de material gravado em áudio e textual, com os comentários mais importantes destacados em julho de 2017. O moderador pedia para os entrevistados "falarem livremente o que pensam". Nos casos 
em que alguns membros do grupo diziam ainda não ter uma opinião formada, eles faziam associações, concordavam com o que fora dito ou mostravam opiniões divergentes a partir das colocações dos demais participantes. Destacamos aqui as perguntas relevantes para o propósito desse trabalho:

1- Identificar se há uma correspondência satisfatória entre as expectativas dos alunos e o que é oferecido no curso de design de moda;

2 - Identificar que tipos de conteúdo, temas e disciplinas são mais relevantes para a formação do aluno na percepção deles;

3 - Identificar se o ambiente, suas instalações e estrutura são adequadas para aprendizagem;

4 - Identificar se os projetos de percurso profissional e carreira estão alinhados com os conteúdos oferecidos pela instituição;

5 - $\quad$ Identificar se a grade de disciplinas curriculares favorece sua inserção no mercado de trabalho e;

6 - Identificar se a instituição oferece oportunidades de inserção no mercado de trabalho a partir de práticas envolvendo aluno e indústria e estágios.

A escolha do perfil dos alunos seguiu os seguintes critérios:

- Idade, endereço de residência;

- Período que está cursando e;

- Situação empregatícia (se trabalha, na área ou não, se fez estágio, se busca fazer).

A seguir seguem as questões que foram destacadas das falas dos alunos referentes a esta tese:

\section{1- Identificar se há uma correspondência satisfatória entre as expectativas dos alunos e o que é oferecido no curso de design de moda:}

No geral a percepção da pesquisadora é que os alunos da unidade B se sentiam confortáveis de estarem cursando design de moda na instituição por se tratar de uma escola de referência para a indústria e também por escutarem de pessoas de gerações 
anteriores a sugestão do nome da escola. Embora haja tradição do nome, uma insatisfação dos alunos referia-se ao espaço de reflexão sobre a atividade do designer. Os alunos disseram sentir falta de um lugar para criação, reflexão e crítica que fugisse um pouco da orientação da produção voltada para a indústria.

Se pensarmos na indústria 4.0 que exige conhecimentos complexos, cujo preceito é utilização de mão de obra cada vez mais qualificada, o questionamento dos alunos é coerente, uma vez que a atividade do designer ocupa uma função central em termos de criação, reflexão e crítica.

R1 tem 25 anos e terminou agora o curso. Ela acha que a faculdade prepara todo mundo sempre "muito igual" e isso faz com que muita matéria aqui seja dada superficialmente, como empreendedorismo, "que você aprende o básico do básico, e dali você não aprende mais nada".

R2 disse que onde ela mora as pessoas acham que seu curso é gratuito e do governo, que ela sempre tem que dizer que é faculdade particular e mostrar o boleto para dizer que não é de graça - uma colega da sua irmã cursou na Cândido Mendes de Niterói, mas todos falavam da ESCOLA M. R2 disse que fizeram "300 projetos criando para indústria" - ela acha que é importante pensar no que está fazendo, (a reflexão) na atividade do designer, e que só depois que acabou a faculdade ela cairá em si que você é, de fato, uma designer.

R3: no MEC estava muito bem colocada, tinha as estrelinhas no guia do estudante. Que o valor também contou, pois, a PUC era absurda de cara, que foi muito recomendada, mas a ESCOLA M era absurdamente mais barata.

TODOS: concordam que para a área de moda, a indicação da escola de referência é o ESCOLA M - principalmente, quando a indicação vem de pessoas mais velhas.

2 - Identificar que tipos de conteúdo, temas e disciplinas são mais relevantes para a formação do aluno na percepção deles; 
A percepção da pesquisadora em relação a relevância que se dá ao conteúdo de disciplinas é que os alunos apreciavam os programas voltados para gestão e empreendedorismo. Consideram cursos extremamente importante na medida em que oferecem o ferramental para que possam, por exemplo, abrir um negócio, criar uma marca e gerir suas finanças. O formato considerado ideal pelos alunos é, por conseguinte, aquele que possibilite desenvolver e aprimorar suas habilidades nos domínios da criação e ao mesmo tempo capacitá-los na área de gestão e finanças.

R4, de 25 anos, não sabe em qual período está. Quando ele entrou as pessoas iam totalmente para indústria e dava tudo certo até a crise que aconteceu e não tem trabalho para ninguém. Ele acha que a ESCOLA M já está caminhando para uma formação que cria alguma autonomia (empreendedorismo), que acha que essa necessidade só surgiu agora. Acha que esse seria um momento perfeito para o a ESCOLA M passar a pensar mais em estimular a criatividade do aluno, o tanto quanto ele já faz na indústria. "Eles (indústria) entendem que com a formação da ESCOLA $M$, nós (formados aqui) conseguimos fazer tudo". Ele sempre trabalhou em empresas com pouca estrutura, que precisavam de alguém como ele, treinado para fazer tudo, mas ele sente essa carência para se tornar um empreendedor, e poder gerir seu próprio negócio. R4 acha que seria bom pensar no indivíduo, na pessoa que vai empreender.

R5 reforçou a parte de incluir o sujeito como autônomo, ou seja, a importância de matérias de gestão.

R6 disse que aprende o básico, faz estágio, e que faz um pouco de cada, mas não sabe fazer com profundidade, dá uma visão bem ampla...

3 - Identificar se o ambiente, suas instalações e estrutura são adequadas para aprendizagem;

As falas dos alunos sobre as mudanças ocorridas dentro e fora da instituição foram impactantes por conta de mudanças na gestão provocou mudanças significativas na estrutura da escola. Tanto na parte física, as mudanças estruturais, constantes obras, 
abandono de algumas áreas que antes tinham um papel fundamental na escola, segundo os alunos tais como o alojamento, a piscina etc.

Eles também enxergam os esforços de melhorias e modernização, mas ao mesmo tempo para o que lhes trouxe uma sensação de "perda". Comparam com as concorrentes e elogiam a escola em termos de organização. A PUC Rio é vista como uma opção inacessível para a maioria. A razão principal seria por ter uma mensalidade 3 vezes maior.

Usam o IED como exemplo contrário ao "clima que paira" da ESCOLA M: "no IED há um clima mais descontraído que respira moda e agrega pessoas por ter uma série de eventos o tempo todo". A localização da ESCOLA M também foi citada como uma grande dificuldade enfrentada pelos alunos. O ambiente em seu entorno mudou significativamente desde a sua implementação. Cercada por um conglomerado de favelas, a questão da segurança e mobilidade aparece de forma recorrente nas falas dos alunos em função do alto índice de violência que ali impera. O local, muitas vezes sofre intervenções militares e fechamento do comércio por parte de criminosos. Tais acontecimentos também atrapalham na promoção de eventos que poderiam atrair pessoas para o campus.

R3 começou na Veiga de Almeida, mas lá era uma "zona" para pegar matéria. Não tinha vaga para tudo - a sala tinha 60 alunos, não tinha cadeira, você precisava de estrutura e não tinha espaço. Ficava desesperada para conseguir vaga na turma. Ficou "desesperada", não conseguiu fazer transferência, teve que fazer tudo de novo (novo vestibular).

R7 fez na Unigranrio. Implorou a família para fazer lá, mas achou uma zona, uma bagunça, professores despreparados, não tinha estrutura (não tinha cadeira na sala). Ela ouvia falar muito bem da ESCOLA M - que sempre diziam que aqui moda era bom.

R7 disse que quando resolveu fazer moda queria uma faculdade pública, mas não tinha. Ela não queria porque todo mundo da escola estava aqui. Ela fez prova para a PUC, mas como é muito cara, não conseguiu bolsa e, então, desistiu. Ela mora perto, em São Cristovão. Ela fez prova para a Cândido Mendes, mas achou horrível. 
Estrutura horrorosa. Aqui achou tudo maravilhoso.

R8 está "assustada" - disse que a ESCOLA M era um em 2010, e hoje é outro. "O alojamento era lotado. Tinha gente, aluno, vida. O jardim era lindo, a estrutura era linda, não tinha cara de obra morta. Tinha aluno! Isso assusta um pouco. Em 2010 era lotado, e hoje andamos numa faculdade fantasma. $E$ isso dá medo, em termos de violência". Demais alunos concordam que isso é "reflexo das mudanças de gestão". A aluna se diz um pouco decepcionada para o caminho que estão indo, "meio decadente". "Sensação de abandono.

R5 chegou em 2012 e era outra faculdade, outro clima. Tinha uma piscina que eles amavam. Acabaram com ela em 2015 e colocaram tapumes em tudo. Kelvin disse que o IED tem vida, sempre tem um evento e que dá um desejo de ir lá, coisas diferentes acontecem num espaço que faz ferver.

Vendo o lado bom, R7 disse que a planta piloto ficou ótima, a academia também melhorou muito, apesar dos problemas, da faculdade ficar muito decadente - mas apesar de ter tudo não é tão fácil usar o maquinário.

- Sobre a comunicação interna os alunos dizem que "é difícil descobrir uma informação correta, a secretaria existe?" Você tem que ligar 4 vezes e falar com 6 ramais até descobrir o que tem que fazer de fato. O novo sistema não funciona direito, ele não é intuitivo.

- Sobre o edital: R7 não estava entendendo quando ia abrir iniciação cientifica porque não sabia onde tinha a pasta, tem vários caminhos que ninguém sabe, que ninguém consegue usar direito. Todos disseram que não existe comunicação com os professores. Eles reivindicam algo simples e prático, o sistema é lento, não é prático, funciona mais um grupo no Facebook.

\section{4 - Identificar se a grade de disciplinas curriculares favorece sua} inserção no mercado de trabalho;

De acordo com os alunos o currículo deveria estar mais alinhado com as expectativas deles de forma que desse margem as escolhas de acordo com o que pensam 
em termos profissionais. A grade deveria ser organizada para várias saídas tendo um ciclo básico e eletivas de acordo com o interesse dos alunos.

R7 disse que está colando grau agora e a experiência com a faculdade é positiva. $A$ base é muito boa, mas falta muita coisa, e o mercado de trabalho é "paralelo a faculdade, o mercado de trabalho é o contrário do que a faculdade oferece. No quesito criação, por exemplo, a faculdade dá ênfase na criação (design, arte) mas falta um pouco a ciência e a tecnologia".

O aluno R5 acabou de terminar a faculdade, concorda com algumas coisas que a R3 e R2 falaram e realmente, segundo o aluno, falta esse link entre faculdade e mercado. Que antigamente existiam feiras aqui dentro, onde o empregador vinha aqui e buscava o aluno para empregar. Ele discorda da Sara sobre a questão de que a faculdade é muito voltada para a área do "criar sem pensar". Segundo o aluno, é muito mais ligada a indústria - que eles não aprendem a criar "nosso produto" e sim para alguma marca. "Nosso mercado está muito ruim porque existe muito do mesmo". O aluno acha que deveria ter um foco para quem não quer seguir a indústria tradicional (processos criativos, outros tipos de design, empreendedorismo, por exemplo, para que possam criar o "nosso").

R9, de 21 anos está no $6^{\circ}$ período e acha que a discussão está ajudando a entender o mercado, que antes não tinha expectativa nenhuma de ser empreendedora, mas que agora é algo que ela pensa com mais frequência. Ela quer seguir uma área no mercado que ela não tem muita experiência. A princípio, ela quer trabalhar com pigmentação natural. Ela tem medo em relação a instituição e mercado no quesito de ser autônoma, para ter confiança que vai conseguir empreender e caminhar para outro lado. Ela não sabe de fato como funcionaria trabalhar com pigmentação, mas sabe que será algo que ela quer empreender, mas não se sente confiante.

R4 diz que aprende mesmo é no mercado de trabalho.

R10 acha que 7 períodos é muito pouco e que deveria estender mais.

R2 acha que dá a base, mas depende do aluno - muitos entram e desistem. Quando começa, sem noção do curso é maravilhoso. Quando você descobre para onde está indo, você vê o que está faltando e o que pode mudar. Para ela atendeu bem sim as 
expectativas. Dá uma base de matérias e network.

R5 entrou em cursos livres e acha que faltam coisas, mas que dá uma base muito boa. Ele foi para Irlanda pelo Ciência sem Fronteiras, e agregou com o conhecimento adquirido na ESCOLA M. Reclamou que o bazar que teve aqui foi um sucesso, mas mesmo assim, não tem mais.

- Precisam reorganizar a grade curricular, por exemplo, o Corel é fundamental e a matéria TCC, as normas ABNT deveriam ser no início para aprender a produzir artigos académicos - antes de acrescentar algo mexer na hierarquia (todos concordaram). Tem matéria que eles não sabem mexer no Corel e precisariam para fazer painéis.

Estrutura de modelagem: não conseguem entender para que ela existe daquela forma, porque o conteúdo da matéria não faz sentido, a professora mostra algo "tosco" com papel e eles pagam uma matéria inteira para fazer algo que não enxergam relevância (R5 disse que depende da professora que com ele foi bem diferente, a matéria está sem alinhamento entre os professores, deveria ter um padrão e com isso você perde conteúdo que outros alunos tem). R6 não sabe para que serviu essa matéria. A professora nem ficava em sala, saía em 30 minutos.

- A matéria de Desenho técnico é rápida e não dá tempo.

- Aulas de gestão: R2 teve uma "péssima, com um professor que era péssimo", num universo que não era dele (de química / física). Ele acha que deveriam trazer alguém mais interessante da nossa área. Alguém que eles tivessem mais respeito, e que respeitasse eles. Querem um professor engajado, e que seja do setor, que atue no mercado, para criar empatia pela pessoa e pela matéria. A diferença de área, fica visível para os alunos que eles querem enfatizar que são de outras áreas. Os de engenharia se acham muito superior. Já R3 achou que sair de moda e pegar matérias na engenharia, foi muito interessante. Acha que uma pessoa de administração seria ótima para dar empreendedorismo.

- Pesquisa de moda: há tendência de dar autonomia ao aluno, e isso deixa eles perdidos. Os precisam de infraestrutura. Acharam que essa matéria seria uma base para fazer todo o resto. É outro caso de DISPARIDADE entre professores. Depende 


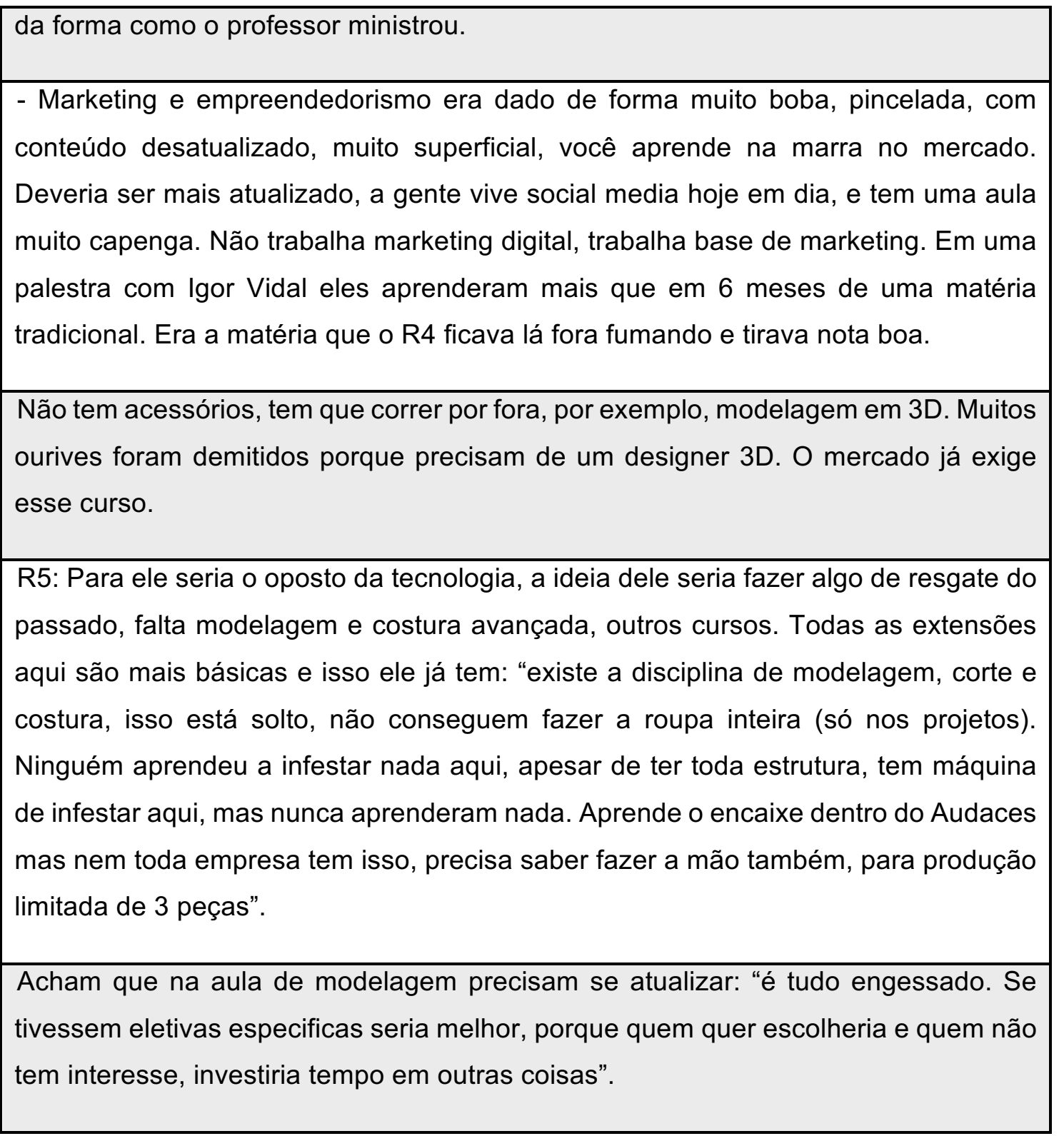

5 - Identificar se a instituição oferece oportunidades de inserção no mercado de trabalho a partir de práticas envolvendo aluno e indústria, estágios etc.;

Segundo os alunos, a dificuldade em encontrar oportunidades de estágio diz respeito defasagem entre o que se prende e as demandas do mercado de moda. Precisamente, os alunos não estão capacitados em termos de técnicas e ferramentas que o mercado de moda utiliza. Também acham pouco funcional a plataforma de cadastro de currículo que é disponibilizada. 
R10 se sente muito inseguro com relação ao futuro por causa da falta de oportunidade no mercado de trabalho que, segundo o aluno, é bem limitado no mercado de moda.

A aluna R2 disse que ia ter uma opção na internet para cadastrar estágio, mas que sente muita dificuldade em usar a plataforma, que isso é crucial. Ela tem 23 anos e está no $7^{\circ}$ período (já era para ter se formado), está há bastante tempo buscando oportunidades.

Ela reclama que existem áreas grandes (mais oportunidades) para quem tem menos formação, ou seja, ela queria que a gente (a instituição) prospectasse quais as áreas de trabalho e vagas existem no mercado na hora de fazer a matrícula. Deu exemplo de uma amiga que queria fazer um curso técnico rápido para ter formação para trabalhar numa determinada marca, enquanto ela está investindo um "tempão" em formação académica ampla - que passa 4 anos estudando e o mercado as vezes absorve pessoas com formação menor.

R3 ressalta que o mercado é muito cruel, é muito difícil. Ela conseguiu alguns estágios, mas todos por indicação, porque a faculdade não mostra o que o mercado de trabalho quer.

R9 tem 20 anos e está no $6^{\circ}$ período, também acha que "falta link com mercado". Ela sente muita dificuldade em conseguir emprego (estágio). Sente medo porque pensava que, como nas outras faculdades, ia conseguir estagiar rápido, quando comparado a amigos de outras áreas.

De acordo com os alunos, faltam programas atuais usados na área de design e moda: "Não tem In design, poucos tinham programas que eles querem usar nos projetos. Ninguém mais usa o Corel, todos estão usando o In design, llustrator, e aqui não tem. Deveria deixar o Corel porque é barato e muitas empresas utilizam, na Animale (marca de moda feminina) usam para tudo. Mas faltam outros programas que eles não estão tendo acesso. Precisam ter uma base básica no currículo para informática porque em todas as entrevistas de emprego querem que você saiba usar o illustrator". 
Moderador: sobre o contexto atual, com a internet, pensando em para onde a sociedade vai, o que se espera de um futuro próximo, vocês costumam procurar informações sobre o futuro da profissão de vocês?

Muitos alunos pensam em enveredar para a área acadêmica, motivo pelo qual também se sentem carentes em termos de conhecimentos mais teóricos e professores que incentivem trabalhos nessa esfera. A maioria dos alunos fez menção às atividades autônomas e ao empreendedorismo - de criar uma marca própria.

R3 pensa em fazer o mestrado acadêmico e quer sem pagar (bolsa de fomento).

Dentro de 10 anos R3 se vê mestra, concluindo um doutorado com pesquisa focada na suscetibilidade e gestão. Quer se especializar em gestão de negócios de moda e outras áreas de interesse. Se vê como professora pesquisadora.

R4 também tem interesse em fazer um mestrado ou uma Pós, apesar de ser muito prático, pensou em graduação em antropologia e continuar com "coisas práticas". Quer lançar uma marca, mas não faz nada ainda para isso. Se vê continuando a estudar, vai continuar sempre na mesma área. Quer produzir para si próprio, não gosta do marketing pelo marketing, pensa no produto. Acredita que tem uma demanda de um público masculino, amplo (agênero) que se interessa por nostalgia, identificação de códigos, tem a ver com lugares, pessoas.

R8 já está com 40 anos e não se vê trabalhando em nenhuma empresa e sim para si mesma. Trabalhou em fábrica, mas não era a praia dela fazer o que mandavam ela quer fazer algo prático - não tem grandes ambições de ser rica, famosa, quer fazer o que dá prazer. Se vê mais ligada ao slow fashion.

R1 pretende trabalhar para alguém, não quer ter negócio. Tanto faz, grande ou pequena marca, quer se especializar mais, aprender mais modelagem, parte técnica - queria usar o Audaces que aprendeu pouco aqui (mais no trabalho).

R10 gosta muito de jornalismo de moda, de escrever, de contar estória. Acha que falta um pouco de matéria de comunicação de moda, na era digital deveria atualizar. Acha que deveria buscar uma atualização.

R9 se imagina trabalhado para uma empresa ou montando seu negócio, gosta de 


\begin{tabular}{|l|}
\hline tudo, não sabe qual caminho escolher. \\
\hline R5 quer ter a marca própria dele com foco masculino jovem com a cara dele. \\
\hline R2 quer ser independente com sua marca, empreendedora, com processos \\
artesanais, slow fashion, patch work etc; e quer aprender todo o processo para poder \\
fazer as etapas com liberdade de criação. \\
\hline R6 quer ser freelancer, talvez empreendedora, mas ainda não sabe. \\
\hline
\end{tabular}

\section{Os pontos altos a serem destacados dessa escuta no que se refere as questões}

\section{de pesquisa são:}

Embora haja um esforço de iniciativas de aproximação entre o ensino e a indústria segundo os alunos sobre o redesenho de currículos, este ainda é percebido como um ponto fraco. Para os alunos existe um sentimento de insegurança em relação ao preparo que eles têm quando buscam oportunidades de inserção profissional.

Disseram ainda sentir falta de aprenderem de forma integrada conteúdos que fossem repensados em termos de relevância para não haver sobreposição de alguns conhecimentos em detrimento de outros. Por vezes, não valorizados em termos de carga horária, por exemplo.

No caso da moda praia, assim como outros segmentos da moda poderia haver uma articulação maior entre os laboratórios de pesquisa e a relação com a indústria. Os atores da educação e indústria poderiam empenhar maiores esforços no sentido de realizar projetos experimentais integradores para o desenvolvimento de habilidades e competências pensando nas ocupações de trabalho de hoje e do futuro. Tal aproximação facilitaria na inserção dos alunos no mercado formal.

Ramificar o ensino com ciclos básicos e matérias optativas foi uma das sugestões dos alunos para que o estudante de design de moda pudesse exercer sua criatividade de acordo com seus interesses. Dessa forma o aluno que se interessasse por determinados segmentos de mercado como o da moda praia teria maiores chances de moldar o ensino aos seus portfólios, para que se sintam mais preparados e tenham uma carreira direcionada em um mercado que abrange diversos nichos, áreas e segmentos. 
1- Identificar se há uma correspondência satisfatória entre as expectativas dos alunos e o que é oferecido no curso de design de moda;

A pesquisadora percebeu que de acordo com as falas dos alunos, em geral a expectativa em relação ao curso é satisfatória, contudo destaca-se alguns trechos que criticam a falta de professores com arcabouço mais teórico para orientar alunos de moda.

Segundo os próprios, há uma ideia de que os projetos devem ser sempre "práticos", pois os alunos buscariam o curso para atuarem na somente na área de criação, o que não corresponde de fato aos anseios de uma totalidade de alunos, que cada vez mais pensam em projetos teóricos e na carreira acadêmica.

\begin{tabular}{|c|}
\hline $\begin{array}{l}\text { A aluna B1 diz que acha que a instituição deveria instigar mais a fazer trabalhos } \\
\text { teóricos. Disse também que ela pesquisou a falta de harmonia entre os atores da } \\
\text { indústria têxtil, e que teve dificuldades para encontrar quem a orientasse. } \\
\text { Complementando, disse que uma faculdade nível bacharelado deveria estimular o } \\
\text { lado teórico também. }\end{array}$ \\
\hline $\begin{array}{l}\text { B2 diz que talvez tenha que se preparar fora daqui, por exemplo, em costura ela não } \\
\text { se sente preparada profissionalmente. }\end{array}$ \\
\hline $\begin{array}{l}\text { B3 começou na ESCOLA M após concluir a faculdade de direito. Disse que, pela } \\
\text { formação dela, sempre gostou de ler e escrever. Segundo a aluna, no ano passado } \\
\text { ela foi para a faculdade Santa Marcelina em SP. Lá, ela teve uma formação que não } \\
\text { teve aqui, (citou várias ferramentas e comparou dizendo que aqui não sabem mexer } \\
\text { "nem no Audaces" (programa digital utilizado em confecções para modelagem plana). } \\
\text { Na carreira da aluna, ela aprendeu coisas que a ESCOLA M não oferece, segundo } \\
\text { ela: "a parte de programa da indústria } 4.0 \text { está aí e deveriam no mínimo aprender } \\
\text { Photoshop e Corel Draw que deveriam ser ministrados primeiro". }\end{array}$ \\
\hline
\end{tabular}

2 - Identificar que tipos de conteúdo, temas e disciplinas são mais relevantes para a formação do aluno na percepção deles;

As falas dos alunos para a questão apresentada foram bastante diversificadas. Notou-se um descompasso entre a expectativa em relação ao que as ementas das 
disciplinas propõem e o conteúdo dado pelos professores. Também em relação ao que é percebido como demanda do mercado atual, segundo os alunos existe um distanciamento entre o que aprendem com o que precisam conhecer para atuarem no mercado, seja para escolher materiais e insumos, seja para aplicarem técnicas para projetar.

A impressão é que de um lado há muita pesquisa e investimento em processos complexos com o uso de tecnologias emergentes disruptivas e plantas têxteis tecnológicas, enquanto de outro os alunos se sentem desprovidos de conhecimentosbase para atuação segura no setor têxtil e de moda. Outro destaque nas falas é em relação a temas de relevância global como discussões sobre questões de gênero, questões do corpo, cultura etc.

Segundo a aluna B4, a matéria de produção de moda, foi a que ela mais estava empolgada e mais saiu frustrada, pois ela não aprendeu a fazer nada com fotografia, luz, etc.

B5 acha que a aula de modelagem não é muito adequada, ela diz que logo aqui que "fazem estudos antropométricos complexos, mas os alunos não aprendem a fazer modelagem maior (escalas de tamanhos maiores como por exemplo plus Size".

B2: Os professores "do mercado", que não são académicos, não usam bibliografia porque não acham importante; e os teóricos "de doutorado", que têm base, foram demitidos. Ainda segundo a aluna: "os professores acham que todos querem ser estilistas, porém nem todos querem trabalhar com isso, mas aqui são muito direcionados para trabalhar com estilo; e a maioria que alimenta o mercado de moda não é estilo; e que durante a faculdade eles não aprendem isso; o foco é muito estilo". Raissa disse que o ideal seria uma matéria interligada (você fazer a modelagem e a costura da mesma peça). Não é só para juntar uma matéria com a outra e sim fazer transdisciplinarmente - não porque os professores são amigos, mas porque é assim no mercado, segundo a aluna.

B6, acha que não aprende muito sobre algumas coisas como ficha técnica e matérias voltadas para indústria. "é uma faculdade voltada para indústria e só tem 1 matéria rápida sobre isso". B6 acha que uma matéria como prototípica e tecnologia da 
confecção deveria ter mais ênfase no curso.

B7, diz que aqui não tem espaço para questionar temas como gênero, raça, corpo, moda "plus size" etc. A aluna diz que na aula de modelagem eles não aprendem a pensar um corpo resistente, não positivado. Ela acha que é preciso reciclar professores para mudar o discurso. Teve aula com X (professora 1) de comunicação sobre Cultura, e trouxe algumas questões, assim como a professora $X$ (professora 2), mas acha pouco porque o ensino aqui é eurocentrado, segundo a aluna que deu como exemplo a exposição no térreo da Unidade da Barra: "então, além de negar outras referências, o aluno aprende mais uma vez a copiar porque no lugar de fazer uma coisa para questionar, por exemplo, a gente está enfrentando uma crise, escassez de material, existe uma contradição no que é feito", segundo a aluna. Cita a exposição sobre sustentabilidade com plástico e diz que os professores não estão trazendo esses motes sociais/ambientais de responsabilidade, etc. para a sala de aula.

B3 disse que falta adequar o conteúdo com as novas tecnologias, indústria 4.0, e que há uma defasagem sobre o tema. O currículo é muito voltado para indústria e ela acha que a indústria carioca não está tão bem assim. O currículo da Santa Marcelina é muito autoral e também não atende segundo B3. "O currículo ideal é algo que equilibre a parte de produção acadêmica com a parte de desenvolvimento criativo, ou seja, pensar desde o tecido - aqui vamos na Caçula (loja de materiais para moda, decoração e afins, tradicional no Rio de Janeiro), e vemos o que é comercial". A aluna acha que o diferencial seria um curso que contemple as oportunidades de mercado, pensar em quem quer fazer ilustração, estamparia etc. para preparar o profissional para tudo.

B5 diz que os alunos não aprendem disciplinas de materiais têxteis - são somente 2 créditos: "você entra e sai da sala e não há como aprender todo o conteúdo, enquanto tem matérias que não são importantes e tem mais crédito".

B2 questionou porque na aula de materiais têxteis os alunos não podem tocar em nada, eles ficam sem noção de como é, disse a aluna, que queria trabalhar outros materiais por estar "cansada de fazer coisas com viscose, algodão, viscolycra". Ainda segundo a aluna, em relação ao ensino, que ela diz ser eurocentrado: "não fazem 
nada de estampa étnica, negro não importa. Não sabem tecido direito, bordado, tricot, crochë, ponto cruz, sapato, acessório, tingimento, padronagem". A aluna narrou uma experiência em uma loja "chegou na Kalimo (fornecedora de malhas/tecidos) e passou vergonha. Poderia tirar 500 matérias de público alvo e entrar com optativas que não sejam no mesmo horário das aulas obrigatórias" segundo B2. De acordo com a aluna, a matéria de "Ética e Cidadania" é "super superficial", deveria ser ética na moda, (aplicado a moda) não falam da comissão de direitos da moda na OAB; deveriam ver questões de plágio na moda por exemplo - deveriam estar olhando o campo (exemplo questões de gênero).

\section{3 - Identificar se o ambiente, suas instalações e estrutura são} adequadas para aprendizagem;

O fato de a escola da Barra ter uma estrutura mais enxuta faz com que haja uma comparação grande em relação a não somente a unidade mais bem equipada, mas também a outras escolas em regiões próximas. Os discursos variaram bastante, sendo a principal queixa relacionada a uma estrutura básica de escritório como por exemplo, o acesso a copiadoras.

B3 disse que em São Paulo, na escola de moda Santa Marcelina, ela tinha toda estrutura para fazer cursos de Corel e Audaces. Aqui ela não sabe nem onde buscar. Depende de o aluno querer e ir atrás, aí tem que pagar por fora. Ela quer fazer calçados e só tem curso em uma escola do SENAI em Nova Friburgo. Na outra faculdade ela poderia focar só em calçados. Disse ainda que aqui não sabe quem poderia nem orientar o TCC. Segundo B3, aqui todos aprendem a fazer roupa de mulher (todos falam que aprendem focado em um manequim 38, reclamam que não saem preparados para trabalhar com outros segmentos, como infantil, plus size, e que não sabem nem fazer gradação de tamanho para plus size).

B5 acha "um absurdo ter um laboratório de fotografia e não poder usar". A aluna quis fazer um desabafo sobre as disciplinas de gestão e de marketing que, segundo ela, não fez efeito nenhum porque ela aprendeu a mesma coisa: "vou ter que fazer curso por fora". 
B7 diz que não existe uma reunião com alunos para falar dos professores, não existe um lugar/canal para se discutir o que está funcionando - não existem fóruns como esse.

Os alunos dizem que não tem DCE (movimento estudantil), segundo os alunos, os professores falam que os alunos não são interessados, mas os alunos sentem falta de uma representação discente.

Os alunos reclamam que a escola não tem copiadora (xerox) e a impressora não funciona há mais de 1 ano e que os professores mandam texto e eles (os alunos) tem que imprimir em casa: "não tem programas de computador, poucas máquinas nos laboratórios". Sobre as ferramentas digitais, os alunos reclamam que falta muita coisa, que "estão no Orkut ainda", exemplo de programas mais utilizados que eles sentem, falta (datado 2017):

1- Photoshop e Rinocero

2- Illustrator

3- Audaces

4- Indesign

Os alunos dizem que não tem acesso a sala de costura a tarde - precisa sempre de um monitor, deveria ter alguém full time. Também sentem falta da biblioteca com horários compatíveis: "a aula começa $7 \mathrm{hs}$ e a menina da biblioteca chega as $9 \mathrm{hs}$, às vezes, os alunos precisam de uma bibliografia e não tem ninguém lá".

\section{4 - Identificar se os projetos de percurso profissional e carreira estão} alinhados com os conteúdos oferecidos pela instituição;

Segundo os alunos, a relação da escola com o mercado profissional não esta alinhada, seja por falta de flexibilidade em relação aos horários de trabalho e dos cursos, ou por incompatibilidade em relação ao conteúdo oferecido e o que as empresas buscam. Mas em geral todos concordam que conseguir oportunidades de estágio no setor é muito dificil requer contatos, indicações e um estreitamento da escola com os representantes da indústria. 
B8, 25 anos, $6^{\circ}$ período, fez administração e está tentando um estágio para ter noção de mercado, não está conseguindo, se sente insegura. Já perdeu oportunidade de estágio por causa do horário e porque não sabe usar llustrator, e que isso deveria ser algo dentro da grade, assim como InDesign, que antes tinha de extensão (era caro, $\mathrm{R} \$ 400$ duas semanas) mas depois "sumiu". A aluna disse que eles tinham optativa de Corel e Photoshop, mas a professora que dava foi demitida, assim como o $\mathrm{X}$ (professor 3 ) e, agora, não tem ninguém para dar a aula: "tem gente no $8^{\circ}$ período que não teve".

Os alunos reclamam que as matérias Comunicação Oral e Escrita, Metodologia e Produção de Texto Acadêmico, junto com as matérias de LIC (SIC), somadas são quase 7, estão repetitivas, falam dos mesmos assuntos; enquanto poderiam "estar fazendo uma aula de joalheria" ou outra matéria que os alunos não saibam: "na prática a grade não está funcionando, apesar de ter sentido, mas da forma que está sendo ministrada, o conteúdo não está alinhado com o que a grade descreve".

B4 acha "contraditória" a matéria sobre portfólio, (voltada para ensinar ao aluno a criar material para inserção no mercado de trabalho) porque os trabalhos feitos na faculdade "não são convincentes".

B6 reclama de estágio, conseguiu por indicação própria, a empresa não dava estágio e às vezes abrem exceção, quando tem alguém para indicar. Ela só entrou no estágio porque é da ESCOLA M. A contratante "não ia nem ler o seu currículo se fosse de outra faculdade" - segundo a aluna.

\section{5 - Identificar se a grade de disciplinas curriculares favorece sua} inserção no mercado de trabalho;

Assim como os alunos do campus B, os alunos do A foram também unânimes no sentido de observar que há um esforço em adaptar o currículo dos cursos para atender as demandas dos alunos e do mercado de trabalho. Observam que embora haja tal esforço, que a grade de disciplinas tem sobreposições de conteúdos e carece, por outro lado, de conhecimentos fundamentais para a atividade do designer de moda.

Algumas capacidades voltadas para a autonomia do sujeito enquanto empreendedor deixam a desejar pois a instituição estaria mais voltada para atender as 
demandas da indústria. Contudo, em tempos de crise e por se tratar de uma geração diferente da época em que a instituição foi criada, a maioria dos alunos pensa em trabalhar por conta própria.

Também fica evidente a falta de entendimento por parte das empresas contratantes em relação ao escopo de trabalho articulado com a capacidade dos alunos de acordo com a etapa escolar que se encontram. Os alunos se sentem prejudicados e segundo eles "explorados", com a sensação de que as empresas preferem mão de obra de estagiário para desempenhar funções de profissionais.

B4, de 21 anos, acha que "faltam algumas matérias" porque quando ela vai fazer entrevista não sabe coisas que o mercado pede como por exemplo, o programa llustrador.

B2, 21 anos, está no terceiro estágio. Diz que só conseguiu porque tem formação em jornalismo: "pela moda eu não conseguiria nada". Em relação a estágios, ela observa que seus colegas quando vão para o processo seletivo para estágio, fazem ficha técnica: "todos os estágios pedem isso e, aqui (na graduação), eles só vão aprender no $6^{\circ}$ período; assim como Portfólio em moda, você não entrega currículo e, aqui, só aprende a fazer no $6^{\circ}$ período". B2 também observa que os professores utilizam plataformas obsoletas, como o blogspot. A aluna B2 complementa que na ESCOLA D está na grade o Illustrator e aqui não: "às vezes, contratam estagiários de arquitetura para trabalhar com moda por causa do preparo, isso tira o meu lugar".

Todos os alunos destacaram: a ficha técnica e o desenho técnico deveriam ser dados no início do programa de aulas.

B4 diz que fica desapontada em ter que pagar caro para aprender coisas, como produção de moda, mas não aprende nada. E marketing também deixou a desejar, segundo a aluna. Diz que a aula de marketing deveria ser como no mercado. Ela não se sente preparada para um estágio porque não aprendeu várias coisas: "deveriam ver o mercado e não ficar com uma grade super antiga, defasada".

B1 diz que a ESCOLA M montou uma grade que foi atualizada, mas isso não foi pensado de uma maneira que não impactasse de forma grave a vida de quem já estava lá dentro. Vai ser melhor para quem está entrando, mas para quem está no 
meio não. O mercado está diferente e precisamos nos adaptarmos ao que vem de novo. As mudanças têm que ocorrer de forma mais amena, tem que pensar em quem está no meio do processo, a mudança não é para sempre, é um habito que deveria ser para sempre na instituição, isso tem que acontecer o tempo todo, por isso deveria ser de forma amena - segundo a aluna. A aluna diz que é exatamente isso que ela trata na monografia dela, que o mercado cobra muito, porém a educação não acompanha. Esses 3 pilares entre educação, mercado e governo não tem harmonia, segundo a aluna B1.

B2 - fala sobre a disciplina de marketing: "você não está se formando em marketing então, tem que ser uma pincelada do assunto". Os alunos estão se formando, aprenderam a modelar, mas não a pensar a modelagem, não raciocinam para fazer sozinhos. Existe o curso mas poderia ser melhor. Deveria ter mais optativas, cada um puxa o que interessa, o design de moda é muito amplo. Deveria formar vários interesses, não tem moda para o público masculino e idoso.

Segundo os alunos: "também queremos empreender, não queremos ser só empregados. Queremos ser empregados (trabalhar na indústria) para aprender. Quem não quer empreender, quer ser grande na estrutura de outro, quando não quer assumir o risco".

Segundo B4, com a crise, os empresários colocam estagiários para fazer coisas de profissionais já formados, e eles (os alunos estagiários) não têm essa base de ensino aqui. Segundo a aluna, teria em um curso de extensão, porém não na ESCOLA M (graduação) .

6 - Identificar se a instituição oferece oportunidades de inserção no mercado de trabalho a partir de práticas envolvendo aluno e indústria, estágios etc.;

Esta questão pode ser correlacionada a número 5. Embora haja um esforço formal da instituição, este não foi mencionado pelos alunos, talvez por terem uma atuação tímida na ponte entre empresas e alunos - de forma superficial. 
$\mathrm{B} 1$, de 22 anos, disse que se atrasou para se formar porque começou a trabalhar muito cedo na FIRJAN, na área de desenvolvimento setorial - com moda. Ela destaca muito a falta de disponibilidade de horário da faculdade para quem precisa fazer estágio. Os alunos ficam sem opção de estudar a tarde ou à noite, sendo "o mercado muito difícil". Ela acha que a academia não está se atualizando para acompanhar as demandas do mercado: "conseguir um estágio é quase impossível, vai muito da network". Contudo, segundo a aluna as empresas que procuram estagiários buscam mais na ESCOLA M, as não existe muita oferta de estágio e há um problema para conseguir conciliar os horários. A aluna se sente instável porque estava trabalhando, mas, agora que acabou o período ela precisa se inserir novamente no mercado.

Os alunos sentem falta de convênios internacionais para estudar fora, pois percebem a experiência como um diferencial competitivo para a carreira deles.

A fim de fazer um paralelo com as questões de pesquisa e com os resultados do grupo focal do campus Riachuelo, destacamos as seguintes observações:

Sobre as iniciativas representativas de aproximação entre o ensino e a indústria, a maioria dos alunos considera importante "saber projetar e empreender simultaneamente" - devido à instabilidade do mercado.

São unânimes quanto a terem que se "moldarem" para acompanhar as oportunidades que surgem, não restringindo suas expertises somente no que gostam de fazer: "o desespero faz você ir se moldando".

Consideram importante para a aproximação entre ensino e indústria as discussões sobre tecnologias emergentes que a escola promove. Reconhecem todo o investimento a nível nacional, contudo, não consideram ter acesso a esse conhecimento "temos noção da importância da tecnologia, mas não temos noção de como seria para chegar lá".

Valorizam professores com doutorado e com experiência prática de mercado, idealmente professores com ambas as experiências. Não chegam a citar especificamente o segmento da moda praia. Chama a atenção estarem pensando muito na inclusão social, nas responsabilidades étnicas e ambientais, no futuro da indústria e no "propósito da moda". 
Querem fazer marcas com impacto social, "nem todo mundo está pensando na resistência”. Segundo a aluna R1 ao contextualizar a questão do consumo no contexto socioambiental global atual.

Querem entender como funciona a indústria, mas talvez para propor algo diferente (empreender em uma escala pequena por exemplo). Pensam no slow fashion como saída em todo o processo. Dessa forma, sentem falta de desenvolverem melhor suas aptidões, habilidades e competências para empreenderem no lugar de terem como opção os empregos formais.

Outros aspectos identificados nos grupos focais variaram desde as discussões sobre questões de gênero até a visão de futuro dos alunos enquanto designers de moda:

A maioria dos alunos é mulher, e quando tem um homem ele vira bicho de estimação dos professores (SIC), assim como no mercado, a maioria dos cargos de direção na moda é de homens, como se para mulher seja comum estar ali, para o homem ele seria especial.

A fala dos alunos em relação a ter autonomia, sobre o empreendedorismo e sobre a responsabilidade ética, social e ambiental se fez muito presente em ambos os grupos. Tais características são sinais importantes para mudanças no repertório de um ensino conectado com uma consciência cosmológica e com a visão do designer enquanto indutor de novas formas de projetar pensando na sustentabilidade complexa do projeto (MORIN, 1982).

Ouvir dos alunos de uma escola que surgiu para atender as demandas da indústria, na maioria das vezes orientada somente para o consumo/lucratividade sobre uma visão ética e humanista de pensar o ensino e o mercado é também um recado importante, uma vez que tais anseios não coincidem com as falas dos representantes da indústria nessa pesquisa. Sobre tal anacronia mostraremos adiante no próximo capítulo 4 . 


\section{5. \\ A experiência como curriculista de cursos de moda com abrangência nacional}

A atualização dos portfólios de cursos de moda ocorreu dentro das etapas do projeto que a pesquisadora participou no SENAI Nacional. Foram feitos levantamentos sobre o estado da arte da educação em moda no Brasil. A pesquisadora participou de reuniões com docentes, de grupos focais com alunos, de um comitê com representantes da indústria (a ser narrado no capítulo 4) e de reuniões com especialistas de outros estados do Brasil. Todas as etapas do projeto foram parte do trabalho de redesenho de currículo realizado em Brasília, DF.

O trabalho com os membros integrantes do grupo de acadêmicos e especialistas docentes na educação do ensino de moda compõe este capítulo para responder as questões de pesquisa sobre como o ensino se articula com a indústria. Para tal, a partir de formulários sobre as capacidades básicas, técnicas, metodológicas, sociais e organizativas se buscou encontrar referências sobre a atuação dos alunos no mercado de trabalho, com base no documento $\mathrm{CBO}$, código brasileiro de ocupações profissionais - uma vez que o SENAI se propõe a formar para o setor de moda.

Diante das informações obtidas buscou-se contextualizar a atuação dos cursos em seus diversos níveis, os correlacionando com a descrição do Catálogo Nacional de Cursos Superiores de Tecnologia e do CBO. A leitura do contexto de trabalho foi realizada com base no que foi informado aos componentes do projeto sobre a Indústria 4.0 contemplada na análise do perfil profissional.

As capacidades técnicas para todas as funções de trabalho foram discutidas pensando no que o aluno deve ser capaz de fazer. Exemplo: para o aluno "considerar as normas técnicas" no "desenvolvimento do produto x", o que ele deve ser capaz de fazer? As capacidades devem trazer os processos cognitivos e não tarefas ou conhecimentos.

As capacidades básicas também foram discutidas para todas as funções que o aluno deve estar apto a desempenhar, respondendo a seguinte pergunta: que capacidade básica o aluno deve ter para a "capacidade técnica"? Da mesma forma, as capacidades sociais, organizativas e metodológicas deveriam ser contempladas seguindo a mesma 
estrutura, embora sejam mais difíceis de serem trabalhadas, uma vez que a parte técnica é objetiva e as sociais (as soft skills por exemplo), são capacidades transversais às diversas áreas.

Feito esse trabalho de diagnóstico, as capacidades básicas foram compiladas e as possíveis repetições excluídas. Iniciou-se o processo de agrupamento por contiguidade e similaridade. A estrutura da unidade curricular é desenhada a partir de um elemento de competência inteiro. Metodologicamente falando, o elemento de competência pode gerar uma única unidade curricular.

A unidade curricular seria um conjunto de competências com base nas capacidades que o aluno precisa desenvolver que formam o currículo. Diferentemente do que é comumente oferecido no ensino em geral, as disciplinas operam de forma fragmentada com base no modelo verticalizado de ensino. As unidades curriculares geradas são nomeadas de acordo com seus enfoques e a carga horária para as unidades é definida com base no tempo necessário para o desenvolvimento do conjunto das capacidades.

A matriz curricular é estruturada gerando módulos a partir das unidades de competências. Os módulos não podem ter mais de 400h distribuídas entre capacidades sociais, organizativas e metodológicas. Por fim, os ambientes pedagógicos para o desenvolvimento das unidades curriculares são desenhados de acordo com as demandas que cada uma requer em termos de espaço físico, estrutura para a aprendizagem etc.

Este trabalho foi realizado em Brasília com grupos interdisciplinares de docentes de diversas áreas atuantes na educação de moda. Com duração de 6 semanas ao longo dos meses de outubro, novembro e dezembro de 2017. Este trabalho gerou a atualização de 18 cursos incluindo o Superior de Design de Moda.

A experiência mostrou que (como será colocado no capitulo 4), a não homogeneidade no uso do vocabulário da moda, se reflete nas falas dos participantes e na dificuldade de um entendimento acerca de determinados conceitos, termos, palavras se expressões. Variavam de sentido de acordo com a região que o participante estava representando. As diferenças na comunicação geravam ruídos nos debates sobre aspectos ligados ao ensino e ao mercado de trabalho no setor da moda. 


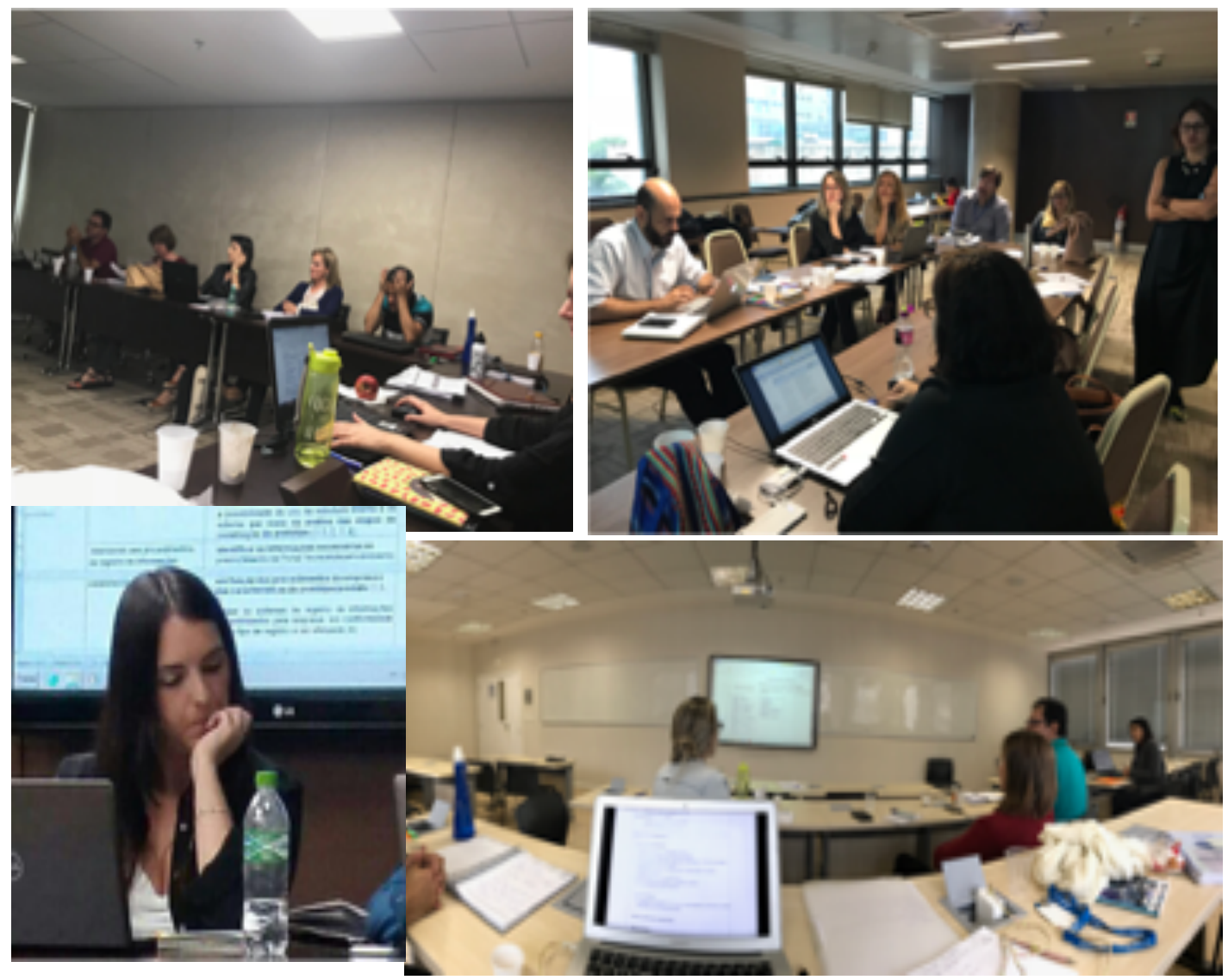

Figura 6: Imagens do trabalho realizado em Brasília em diversos momentos das tapas do projeto de desenho de currículo dos cursos de design de moda e técnicos, SENAI Nacional.

O grupo de docentes composto com integrantes de norte a sul, evidenciou o descompasso também em termos de estrutura tecnológica que cada um tinha como referência. Os docentes do SENAI CETIQT por exemplo, tinham uma visão mais privilegiada sobre indústria 4.0. A instituição a qual estavam representando possui um parque tecnológico com diversas plantas de confecção e mini fábricas com máquinas modernas e investimento em pesquisa na área.

As discussões em torno da relevância de determinados conhecimentos dentro de cada unidade curricular levaram em consideração as falas dos representantes da indústria participantes do CTS (vide capítulo 4), no sentido de tornar o ensino aderente as demandas apontadas por eles. Contudo, nem sempre houve uma unanimidade na 
adesão do que era apontoado como demanda da indústria para a atualização dos currículos.

Muitas vezes, por entender que é papel da educação ser indutora de mudanças e de inovação, em consonância com as respostas dos alunos dos grupos focais, os docentes discutiram sobre o sentido de pensar um ensino que forme antes de tudo um ser humano com ética, com valores humanitários, com responsabilidade socioambiental etc.

Ao longo do processo de redesenho de currículo, a pesquisadora pôde realizar um questionário com uma das integrantes do projeto, a professora Diva da Costa (em dezembro de 2017). A escolha se deu com base na forte atuação da docente em diversas disciplinas e atividades ligadas ao ensino de moda e pela percepção da pesquisadora de que a professora era frequentemente requisitada pelos coordenadores pedagógicos quando surgiam debates importantes. De acordo com as questões de pesquisa Diva respondeu a um questionário online reproduzido nesta tese:

\title{
1- Como você enxerga a relação entre ensino e indústria atualmente?
}

\begin{abstract}
Atualmente, observo que as instituições de Educação Profissional e Tecnológica estão cada vez mais focadas em atender às necessidades da indústria, formando profissionais adequados às funções que irão exercer. E de acordo com o Ministério da Educação, o planejamento curricular dessas instituições fundamentam-se no compromisso em oferecer cursos e programas que concretizem o perfil profissional, requeridos pela natureza do trabalho.

Assim, essa aproximação com a indústria se faz extremamente necessária para que se consiga captar as necessidades das empresas do setor e entender quais são as funções desse profissional. Assim, consegue-se formatar currículos e projetos pedagógicos alinhados e que realmente desenvolvam as competências desses profissionais. Ou seja, conhecimentos, habilidades e atitudes que os profissionais, cada vez mais polivalentes, precisam ter e ser em um ambiente profissional.
\end{abstract}

2- Quais os impactos da aproximação entre ensino e indústria no setor têxtil / vestuário?

Os impactos são enormes, pois o ensino deve ter como objetivo fundamental preparar profissionais para entrarem no mercado de trabalho. E por meio dessa aproximação, as instituições de ensino conseguem desenvolver processos e estratégias de aprendizagem, como por exemplo, os projetos integradores, que mobilizam uma série de conhecimentos, atitudes e habilidades para que o aluno possa mostrar o que ele aprendeu por meio da prática, aplicada em situações e/ou problemas reais do mercado.

3- Pensando na moda praia como benchmark nacional: 
Como você vê os profissionais recém-formados?

Alguns profissionais recém-formados não possuem a vivência daquele setor, a experiência da prática profissional, que muitas vezes é viabilizada por meio de estágios e/ou projetos de iniciação científica.

Eles chegam preparados para atuar no setor?

Entendo que muitos não chegam preparados para atuar no setor, até pelo fato de que algumas instituições de ensino superior, por exemplo, não enfatizam a prática profissional real, com situações problemas, com desafios, e que promovem o aprendizado de forma mais prática. A aproximação com o mercado é fundamental para inserções desses ainda alunos, em visita técnicas, em vivências na indústria.

4- Você enxerga alguma iniciativa para aproximação entre ensino e indústria no segmento de moda praia?

O SENAI Brasil Fashion é um concurso anual entre estudantes do SENAI de todo o Brasil, e há uma aproximação com grandes nomes da moda em relação à aproximação desses alunos com o mercado de trabalho. A Lenny Niemeyer é uma das mentoras do projeto. Porém, o foco não é moda praia, e sim as coleções criativas dos alunos, podendo seguir para moda praia ou não. Fora isso, não consigo me lembrar de nenhuma outra iniciativa.

\section{5- O conhecimento em torno da moda praia está disponível para quem deseja} projetar? (Designer)

Atualmente vejo alguns cursos no mercado focados em "Modelagem para Moda Praia" ou até mesmo "Estamparia", que pode ser aplicado na moda praia. Mas vejo que falta algo mais específico para essa área. Como a moda praia nunca foi meu foco principal, vejo que tenho que pesquisar mais para poder responder com mais assertividade essa pergunta.

\section{6 - O conhecimento em torno da moda praia está disponível para quem deseja empreender?}

O SEBRAE disponibiliza de alguns materiais e reports (relatórios) bem interessantes sobre diversos setores da moda, inclusive sobre moda praia. Nos links abaixo podem ser visitados alguns desses materiais:

https://www.sebrae.com.br/sites/PortalSebrae/ideias/como-montar-uma-confeccao-de-modapraia,f0687a51b9105410VgnVCM1000003b74010aRCRD

https://www.sebrae.com.br/sites/PortalSebrae/ideias/como-montar-uma-confeccao-de-roupasde-surf-e-skate,ae397a51b9105410VgnVCM1000003b74010aRCRD

7 - Na sua visão, quais os possíveis impactos da chamada indústria 4.0 no segmento da moda praia?

Um dos princípios da indústria 4.0 é a personalização e individualização, o que pode ser extremamente benéfico para o segmento moda praia. Vejo algumas de minhas amigas com dificuldades de comprar biquíni, por não encontrar tamanhos compatíveis com seu corpo, ou 
até mesmo estampas e cores que não agradam quando encontram o tamanho adequado. Assim, a Indústria 4.0 poderia ter um impacto nesse sentido, ao poder produzir uma peça personalizada, com cores e estampas a escolha do cliente, e principalmente, com o tamanho apropriado.

\section{8- Considerações finais}

A aproximação do Ensino com a Indústria é extremamente importante, pois o mercado de trabalho precisa ter profissionais competentes. Entender quais competências esses profissionais precisam ter é uma estratégia, inclusive se pensarmos em design thinking e em toda a percepção de necessidade do usuário, podemos concluir que, a Industria é o usuário, e o profissional é o "projeto" que será entregue para atender sua necessidade.

\section{6}

\section{A percepção sobre o ensino de moda praia segundo alunos de graduação em design de moda da PUC-Rio}

Durante o estágio em docência em 2016, com alunos de design de moda da PUCRio, a pesquisadora pôde aproveitar o espaço em sala de aula para passar um questionário com o objetivo de saber a opinião daqueles alunos em relação a relevância dos conteúdos ligados à moda praia, dentro de um contexto maior no ensino de moda. A turma do primeiro período da disciplina "Questões em design de moda" da professora Luiza Marcier, respondeu a um documento que continha uma tabela com escala de 5 pontos.

Para não viciar o questionário, deixando-o tendencioso, foi apresentada uma série de opções amplas de conteúdos para o ensino, até chegarmos nas perguntas mais específicas. Tais opções foram pensadas de acordo com os resultados das análises dos discursos dos entrevistados e do grupo focal, realizado em etapa anterior. As respostas foram compiladas e tabuladas com 15 alunos participantes no total. O número pequeno da amostra refletiu o número de estudantes matriculados naquele ano/disciplina.

Os primeiros resultados colocam o ensino sobre a moda praia como importante na percepção dos alunos, sendo que a maioria considerou ser muito importante. Ninguém considerou ser fundamental: 
1 - Marque com um x os conteúdos você acha importante aprender no seu curso de moda:

\begin{tabular}{|c|c|c|c|c|c|}
\hline conteúdo & $\begin{array}{c}\text { nada } \\
\text { importante }\end{array}$ & $\begin{array}{c}\text { médio } \\
\text { importante }\end{array}$ & indiferente & $\begin{array}{c}\text { muito } \\
\text { importante }\end{array}$ & $\begin{array}{c}\text { fundament } \\
\text { al }\end{array}$ \\
\hline modelagem & & 1 & & 2 & 12 \\
\hline história da moda & & & & 6 & 9 \\
\hline arte & & 3 & & 10 & 2 \\
\hline $\begin{array}{l}\text { aspectos } \\
\text { culturais e } \\
\text { sociais }\end{array}$ & & 5 & & 7 & 3 \\
\hline $\begin{array}{l}\text { sobre o } \\
\text { mercado }\end{array}$ & & 1 & & 7 & 7 \\
\hline $\begin{array}{c}\text { jornalismo de } \\
\text { moda }\end{array}$ & & 4 & 3 & 5 & 3 \\
\hline $\begin{array}{c}\text { marketing de } \\
\text { moda }\end{array}$ & & 4 & 1 & 8 & 2 \\
\hline jeans & & 4 & 1 & 7 & 3 \\
\hline joias & & 5 & & 7 & 3 \\
\hline $\begin{array}{c}\text { novas } \\
\text { tecnologias }\end{array}$ & & 3 & & 8 & 4 \\
\hline materiais têxteis & & 1 & & 3 & 11 \\
\hline Moda praia & & 6 & 1 & 8 & \\
\hline Acessórios & & 4 & & 9 & 2 \\
\hline Bolsas & & 4 & 1 & 8 & 2 \\
\hline Sapatos & & 4 & 1 & 7 & 3 \\
\hline $\begin{array}{c}\text { planejamento de } \\
\text { coleção }\end{array}$ & & & & 5 & 10 \\
\hline Indumentária & & & 2 & 6 & 7 \\
\hline Padronagem & & 2 & 2 & 4 & 7 \\
\hline Desenho & & 4 & 1 & 3 & 7 \\
\hline
\end{tabular}

Ao final foi pedido que os alunos fizessem uma pesquisa sobre moda praia utilizando o celular. A orientação era para eles descreverem o passo a passo de sua busca para pesquisar sobre o tema. As palavras chaves mais utilizadas foram: "moda praia", "biquíni", "tendências de moda praia". Os endereços eletrônicos mais citados foram: Google, Sebrae, sites de marcas conhecidas. Alguns alunos usaram redes sociais.

Para saber qual o nível de entendimento do funcionamento do segmento de moda praia, da etapa de criação até as etapas de confecção e varejo, pedimos que os alunos 
colocassem em ordem hierárquica as etapas do processo. O objetivo era saber se eles conseguiam correlacionar as demandas reais do setor de moda, usando o segmento da moda praia como exemplo, com os conteúdos oferecidos nas disciplinas do curso:

\begin{tabular}{|l|l|}
\hline A) criar peças pilotos & $1-$ \\
\hline B) desenhar / desenvolver coleção & $2-$ \\
\hline C) modelagem (saber pelo menos noções) & $3-$ \\
\hline D) pesquisa de estilo / tendências & $4-$ \\
\hline E) costura (saber pelo menos noções) & $5-$ \\
\hline F) saber o contexto cultural, social e histórico & $6-$ \\
\hline G) achar o nicho, criar target e posicionar a marca & $7-$ \\
\hline H) Fazer prova / ajustes & $8-$ \\
\hline I) divulgação produção fotos e desfiles & $9-$ \\
\hline J) comercialização & $10-$ \\
\hline K) noções de engenharia têxtil e inovação & $11-$ \\
\hline
\end{tabular}

Os resultados da hierarquização das informações que os alunos fizeram refletiram um entendimento sobre como funciona uma produção de moda, de acordo com a tabela apresentada. Sobre qual a melhor forma de aprender a projetar a moda praia, oferecemos 7 opções para a escolha de uma delas, entre: pesquisa na internet, cursos online (EAD), exposições, museu, faculdade de moda, cursos livres.

A maioria dos respondentes assinalou as opções "na faculdade de moda" (11 respondentes) e "em cursos livres", (4 respondentes) ou seja, há uma predisposição em aprender em sala de aula no lugar de outras formas/ambientes de ensino, inclusive excluíram o ensino à distancia (EAD).

\section{Grupo Focal dos alunos de design da ESCOLA D}

Por entender que cada instituição possui particularidades que divergem em objetivos e formato mesmo quando ofertam a formação na mesma área, a pesquisadora se reuniu com alunos de outra escola de moda no Rio de Janeiro. Os alunos participantes estavam cursando disciplinas do $4^{\circ}$ período em diante. Pelo sistema da ESCOLA D, não há uma homogeneidade em termos de ano/disciplinas, uma vez que 
são os alunos que montam suas grades, de acordo com as regras e sugestões do Departamento e da disponibilidade e interesse individual.

As perguntas e respostas foram gravadas e transcritas em áudio com autorização por escrito dos participantes. Os discursos analisados ora se assemelham com as dos alunos da ESCOLA M, ora divergiam. O objetivo do registro é propor um diálogo e destacar as similaridades e diferenças entre alunos e escolas. O texto transcrito não foi modificado no sentido de acompanhar a norma culta da língua portuguesa, a fim de manter a fidelidade com a maneira que os jovens se manifestaram. Foram dois momentos de entrevistas, no dia 24 de outubro de 2018 e no dia 21 de novembro de 2018 com as alunas de moda a partir do $6^{\circ}$ período.

Vocês identificam uma correspondência satisfatória entre as expectativas de vocês e o que é oferecido no curso de design?

P1- Eu faço Engenharia de produto. A maioria dos estágios quer que a gente saiba programas $3 \mathrm{D}$, só que obrigatoriamente no curso a gente só tem uma matéria que ensina isso, e só no projeto 7 e 8 que demandam a aplicação desses programas durante o projeto, então existe uma lacuna, acho que falta um pouco de preparação diretamente no mercado, aqui é mais teórico do que na prática.

Janara - Todos concordam com essa visão?

P2- Eu concordo, mas o mercado de trabalho, principalmente no Design aqui no Brasil, eu vejo isso muito em relação ao estágio. As pessoas querem um estagiário de design e às vezes as empresas não têm nem um (designer), então você acumula várias funções que deveriam ser subdivididas entre outros profissionais, acho que isso acontece muito também. Eu, no meu estágio faço a função de designer gráfica, VM e designer de produto, então é óbvio que sinto essa dificuldade, mas eles também exigem muito da gente, em relação a isso, temos que sucumbir, é tudo em uma pessoa só.

Pesquisadora: então o que você está dizendo é que existe uma divergência no entendimento da parte das empresas sobre o escopo do que cada curso oferece, quais as capacidades e competências que aqueles alunos teriam para desempenharem as funções que eles querem?

P3- Acho que às vezes não é só falta de entendimento por parte das empresas, eles optam por ter apenas por um profissional ou dois profissionais para fazer essa série de funções de propósito para você ter que fazer tudo. Aí você coloca todas as atribuições 
e ele que se vire... (inaudível) e isso é subutilizar (SIC) a capacidade do estagiário como um funcionário.

P4- Eu sou de Comunicação Visual, e basicamente na Comunicação Visual o que você tem é a parte de diagramação né, é o que rege um pouco a habilitação e eles estão criando uma matéria obrigatória disso na grade, ela só aparece como optativa, então é uma optativa de diagramação mesmo. A gente não aprende design no quadro, você aprende por conta própria, eu, por exemplo, sabia zero de Indesign e fui aprender mesmo e mais no estágio e depois me aprofundei mais.

\section{1- Os tipos de conteúdo, temas e disciplinas são relevantes para vocês no mercado de trabalho?}

P5- Eu acho muito teórico e não prático. Eu acho que algumas matérias que são práticas deveriam ser teóricas e algumas que são teóricas deveriam ser práticas. Acho que às vezes não tem coerência nas matérias e também sinto falta de matérias interessantes teóricas.

P6- O que falta é o diálogo entre as matérias. Nosso Departamento tem muitos professores e muitos não se conhecem. Não se comunicam, não têm a habilidade de trocar informações do que cada um esta fazendo dentro de cada matéria, e às vezes, as matérias super tem a ver e você não consegue relacionar porque não existe essa comunicação entre eles.

P7- Eu acho que a gente aqui tem muita dificuldade de aprender essas ferramentas para entrar no mercado de trabalho, porque eu sinto que quando é para estágio eles (empresas) querem que você seja ferramenta, não tanto um designer de criar conceitos e tudo mais, você tem que pensar no conceito, pensar no usuário - mas você não entra como estagiário pensando nessas questões. Passa longe de você todas essas noções você tem que fazer isso, tem que fazer aquilo de ferramentas que você não consegue ter acesso na ESCOLA D, por exemplo. Muitos estágios pedem (nome inaudível de programa), e ele (programa) bate exatamente com o projeto 3, 4 e 5 e você só consegue fazer a partir do sétimo quando você já está no final da faculdade. Você já teria que ter passado pelo estágio e outras experiências, eu acho que tem sim um descompasso.

P3- O resultado disso é que muita gente de produto acaba migrando para outras áreas. Por exemplo, eu tentei no semestre passado um estágio em um escritório de arquitetura que eles tinham design de produto, móveis e tal que é o que eu quero fazer, quero trabalhar. Mas uma coisa que eles pediam era CAD, (inaudível nome de ferramenta) que é exatamente o que a gente aprende só o sólido (inaudível programa) que a gente só aprende no quarto período. Então muita gente acaba migrando para o design gráfico (...).

P8 - Uma coisa que acontece muito, não só no mercado de trabalho, mas direto na faculdade, é que chegou no projeto final de produto, você é obrigado a fazer alguma coisa em 3D, sendo que você ficou metade de um período para aprender Rino e você quase não aprende. E aí você aprende 3GMax. Não é sempre que você consegue fazer quase nada nele e o Sólido que você só faz se quiser e se der porque no seu horário só tem um professor para dar a matéria. Eles cobram umas coisas que eles nem 
disponibilizam tanto para os alunos. Tem matéria que só tem, por exemplo, quinta às 7 da manhã. Se você não pega ela no período que ela é programada para ser daí você fica enrolando porque ela vai bater com o projeto final. Vai bater com um monte de coisas e você não tem muita opção além de quinta às 7 da manhã.

P9: Ela bate também com muitas matérias obrigatórias (inaudível) para conseguir cumprir os horários. Até quando você começa a estagiar tem muitas matérias que seriam úteis para gente no final da faculdade, que são só a tarde, que quem está estagiando e trabalhando já não consegue pegar também.

P10- Eu sou (da turma) de mídia. Às vezes, tem algumas matérias dentro de mídia que precisam de matérias de Comunicação Visual, por exemplo. Você não vai usar tipografia sem cor, sem diagramação, tem muita coisa. Você precisa de coisas de comunicação visual e às vezes pra você puxar matérias de comunicação visual é difícil. Então é difícil pra você se tornar um profissional melhor. Sair daqui da faculdade com uma condição melhor para o mercado e também essa questão de relação entre as matérias, às vezes o professor está lá dando diagramação para você e não fala como que é no design gráfico - é como se fizessem um bloco de coisas e esquecessem que essas pessoas existem (que os professores não se comunicam).

P5- Eu queria falar uma coisa meio polêmica: filosofia de 4 créditos, sociologia de 4 créditos também etc., no final das contas são 16 créditos de religiosa e acho que somente 10 de matéria em laboratório. Não sei se isso é coerente, acho que tem algumas pessoas que super concordam com isso, mas a maioria dessas matérias são insuportáveis de fazer. É difícil um professor que seja legal e você é bem cobrado sobre elas. Às vezes até o professor não leva a própria matéria a sério.

\section{2- Quais são os tipos de disciplinas, temas, conteúdos que são mais relevantes para formação na percepção de vocês, pensando na questão} do mercado de trabalho?

P9: A modelagem virtual seria uma, os programas lá do começo do segundo período, a gente tem Illustrator e Photophop, então faz diferença a gente aprender o ciclo básico do básico, mas só tem uma aula disso e é dividido.

P11- A modelagem 3D é muito importante porque hoje em dia tudo está sendo na modelagem 3D, mas e o sketch mesmo de produto? A gente teve uma aula que foi uma colaboração em um projeto, a gente não teve uma aula de sketch de produto, que é aquele rabisco rápido. Foi uma coisa passada muito rápida. Eu tive no intercâmbio recentemente em Portugal e lá os professores não conversavam se você não tivesse um sketch, e você via o sketch das pessoas. Eu tinha vergonha de mostrar os meus desenhos porque os deles eram perfeitos porque eles já vinham testando há um tempo, eles faziam um módulo só de sketch.

P9: E cor? A gente tem aula de cor nas habilitações, mas mídia não tem aula de cor. A gente tem que se infiltrar numa aula de cor de Comunicação Visual. No meu caso, eu faço "Produto", a aula de cor foi legal, eu aprendi o basicão e saturado mas faltou a aplicação. Faltou eu entender onde eu posso aplicar essas coisas e em que materiais 
diferentes. Eu fiz aquilo num lápis de cor e tinta. Por exemplo, se gosto de carro como aplico cor numa pintura automotiva?

\section{3- A grade de disciplina favorece a inserção do mercado?}

P9- Eu discordo, eu não acho que as matérias devam ter a ver com o mercado. Acho que a relação que o professor tem com a gente deve estimular a gente a participar do mercado.

P12- No Design de Produto (na aula) foi a primeira vez que eu vi uma cobrança. No manual de produção, de como você faz para produzir esse produto como indústria, no caso de desenho industrial e de produto. E tem matéria de processo, mas eu não vejo muito o ensino voltado para isso. Você aprende a fazer o protótipo manual aqui, mas como você faz isso em escala industrial? Você não é estimulado a pensar o tempo todo no produto e você não faz nenhum produto se você não pensar em uma escala industrial (...) o "buraco" é muito grande. A faculdade tem que estar sempre ligada ao mercado de trabalho e as vezes o mercado de trabalho perde alguns valores que você aprende na faculdade: conceituação, a ideia de ter todo um estudo a partir daquele produto e não só um ensaio de 1 hora e desenho aleatório. Eu acho importante a gente valorizar isso na faculdade, nos formarmos profissionais mais qualificados, mas ao mesmo tempo, a gente não pode sair tão desamparado em questões sérias. A gente não pode ficar sem saber escala num curso que o nome é desenho industrial.

P13- Eu Já fui formado em outro curso. Eu percebo que em quase todos os cursos é muito difícil você se adequar ao mercado, ou porque o mercado é abrangente ou porque em 4 anos a gente aprende bastante coisas. A gente precisa entender o que é o design, não só as matérias práticas, mas também as teóricas, mas tudo muda muito rápido, até por questões burocráticas do MEC.

P14- Existe uma diferença entre o técnico que ensina diferentes programas e existe o diferencial da ESCOLA D, que é o que a gente ouve desde o primeiro período, design social, e as melhores matérias que eu tive na ESCOLA D foram muito teóricas, que falam de antropologia, sociologia. O problema que tenho com o curso é que eles acham que a gente vai estagiar com o Índio da Costa, vai trabalhar muito na indústria, saber utilizar programas na indústria. Tem que abranger todos os campos que um designer pode trabalhar.

P15- Eu faço iniciação científica do segundo período. Eu adoro e abriu muitas portas para mim, e às vezes eu chego nas aulas desses professores que fazem essas exigências, que querem catequizar você com índio da Costa e praticamente te enfiam goela abaixo. Quando você fala que quer fazer pesquisa, eles simplesmente falam “ah!"... Então dá pra contar nos dedos os professores que nos influenciam a trabalhar com esse tipo de coisa (pesquisa científica).

P16- Os professores de Produto já trabalharam nesse mercado de trabalho, então falta um pouco de discussão dentro do curso, de quais são os anseios dos alunos quando chegam no projeto final. E tem essa questão de você produzir alguma coisa e tem muitas pessoas que estão batendo de frente com o projeto final porque não querem fazer uma coisa para a indústria. Querem criar algo novo, querem de repente, transformar aquele projeto em uma coisa empreendedora, e às vezes batem muito que 
você precisa ter um manual de produção. Então a experiência que eles tiveram mudou, tudo está acontecendo muito rápido.

\section{4- A instituição oferece oportunidade e inserção no mercado de trabalho a partir de prática envolvendo aluno e indústria, como estágio?}

P4- A ESCOLA D não tem muito dessa inserção no mercado não. Eles colocam muito mais coisas para você trabalhar aqui, nos laboratórios ou então no próprio escritório modelo. Acaba ficando tudo muito aqui dentro e a minha visão é para fora, e é algo que vai pelo boca a boca, a gente descobre os estágios através dos outros alunos, não é a ESCOLA D que informa.

P17- Algumas pessoas não sabem, mas a ESCOLA D tem um Departamento onde disponibiliza as vagas, eles atualizam todos os dias, é só você chegar lá e conversar e eles são muito abertos.

\section{5- Existe parcerias com empresas grandes aqui para o Departamento?}

P18- Tem um projeto, parece que o projeto cinco que teve uma parceria.

P14- O laboratório de volume para mim foi essencial para me inserir no mercado de trabalho, porque no segundo semestre falaram que eu não podia fazer mais trabalhos visuais lá. Daí fui procurar uma oficina onde eu pudesse trabalhar e encontrei lá. Eu comecei fazer uma linha de produtos de madeira e falaram pra mim que eu não podia fazer lá.

P10- Não é nem por falta de estímulo, mas é porque você tem que ter permissão para continuar usando o laboratório para o seu projeto, ou seja, quem está dentro da faculdade não pode usar, mas quem está fora pode.

P19- Eu concordo com tudo o que eles falaram, tem falta de diálogo mesmo, até entre os alunos falta diálogo entre a gente e o departamento, com o que a gente precisa.

De acordo com as falas dos alunos da ESCOLA D, conclui-se que mesmo a instituição oferecendo um formato em que os alunos podem montar os conteúdos, ${ }^{90} \mathrm{de}$ acordo com suas competências, interesses e objetivos, nem sempre o ensino é totalmente complementar quando se trata da comunicação entre os professores em relação aos seus respectivos planos de aula. Pela fala dos alunos, se houvesse maior

\footnotetext{
${ }^{90}$ Dentro de certos limites que compõem o escopo de cada área e da respectiva grade curricular seguindo os moldes instituídos pelos órgãos que regulam as normas para as áreas de educação como o MEC, as convenções de cada departamento e de cada instituição.
} 
integração entre os docentes haveria uma linearidade no ensino e uma troca que favoreceria os alunos em seus processos de aprendizagem.

Fica claro também que há uma expectativa maior do que a realidade em relação ao papel das instituições de ensino no processo de transição para o mercado de trabalho. A maioria dos respondentes disseram encontrar dificuldades para conseguir estágios em empresas e que as mesmas não entendem o real objetivo do estágio.

As falas denunciaram um certo senso de oportunismo como prática de mercado: as empresas estariam buscando uma mão de obra hiper qualificada com baixo custo ao contratarem estagiários para exercerem funções de alta responsabilidade de um profissional experiente ou ao delegarem funções meramente técnicas, como o uso de determinadas ferramentas tecnológicas em detrimento da participação em etapas do desenvolvimento de projeto. A experiência nas empresas é fundamental para complementar o aprendizado fazendo interface entre a educação recebida na universidade e o aprendizado durante a etapa do estágio no mercado de trabalho. 


\section{4 \\ A RELAÇÃO ENTRE O ENSINO E A INDÚSTRIA NA VISÃO DE REPRESENTANTES DA INDÚSTRIA}

4.1

Apresentação do capítulo

Este capítulo tem como objetivo dar voz aos representantes da indústria que participaram desta pesquisa. Buscou-se saber como eles enxergam a relação da indústria com a educação no setor de moda. A partir das perguntas de pesquisa para fazer um paralelismo entre a visão dos alunos, professores e acadêmicos em geral, propomos uma reflexão a fim de entender as aproximações e descompassos na percepção de ambos.

A metodologia utilizada, seguindo a que apresentamos no capítulo introdutório foi a pesquisa de natureza exploratória e qualitativa. O levantamento de informações em pesquisas já validadas, ocorreu ao longo do desenvolvimento desta tese, a partir da coleta de informações de consultorias especializadas do setor de moda, além da bibliografia já apresentada.

As pesquisas de campo e aplicação de questionários foram feitas com notórios da indústria (associações, sindicatos, empresas fornecedoras de insumos, varejistas e marcas de moda em geral). Também participaram especialistas da FIRJAN, especialmente sobre incentivos e publicações acerca da moda praia durante um evento de moda no Rio de Janeiro.

Este capítulo também contempla entrevistas feitas com designers, profissionais do setor nas áreas de modelagem, corte, pilotagem, produção e compras. Foram feitas visitas técnicas à empresas, o "chão de fábrica" para diagnóstico e levantamento de informações sobre processos de design e produção com a fala de funcionários do grupo empresarial Inbrands. O grupo possui diversas marcas cariocas dentre elas a Salinas sob direção de sua fundadora, Jacqueline de Biase. 


\section{2}

A voz de representantes do "apoio a Indústria e à educação profissional" do Rio de Janeiro, via "Sistema S"

A primeira investida no campo para o mapeamento dos espaços de diálogo entre indústria e educação ocorreu em um evento que historicamente foi o ponto alto do calendário da moda carioca. Patrocinado por instituições como o Sistema FIRJAN, (dentre outros como SENAI, SEBRAE, SENAC e SESI). O "Rio Moda Rio" edição de 2016 ocorre periodicamente na zona portuária do Rio de Janeiro.

O evento é marcado por uma mistura de promoção de marcas novas e outras já posicionadas no mercado, palestras e bazares. Reúne compradores com CNPJ (empresas, pessoa jurídica, donos de multimarcas de todo o país) e o grande público, interessado nas palestras ou em barganhar produtos com desconto. A FIRJAN geralmente promove palestras com discussões sobre moda, e a moda praia é sempre tema para tais encontros. Nesse contexto, a palestra "moda praia - selo estratégico para o Rio de Janeiro" foi um oportunidade para a pesquisadora conversar com as palestrantes, a fim de entender a publicação lançada na mesma ocasião.

Houve a distribuição da publicação anunciada como livro intitulada "Cenário \#praia" durante o evento. Embora o formato fosse de livro, tal publicação não possuía ISBN. O texto foi dividido em 2 partes: a primeira com o levantamento histórico sobre a cultura de praia e recorte que começa nos banhos terapêuticos da prática que veio do higienismo com D. João VI. A segunda parte contemplava uma visão mais técnica com dados sobre o setor e informações sobre processos de design, estamparia, modelagem, materiais e tecnologias emergentes.

Apesar do texto explorar a parte conceitual/histórica e ao mesmo tempo a prática, dando ao leitor que busca empreender ou projetar informações relevantes, ainda assim se trata de uma "pincelada" superficial que cumpre a função da promoção do segmento atrelado às inciativas da instituição (ligada ao ensino para indústria carioca).

A conversa com as palestrantes Ariane Alves e Milena Cariello, foi gravada após a apresentação do livro, com autorização das entrevistadas. Ocorreu com base em perguntas semiestruturadas: sobre a importância da moda praia para o mercado 
brasileiro, sobre as demandas do mercado, sobre o ensino de moda praia nas escolas de design/moda e sobre o estado da arte em relação as iniciativas para promover este segmento.

A percepção da pesquisadora a partir da análise do discurso é que a narrativa escolhida foi dando enfoque no sentido da promoção da moda-praia como um bem de valor inegável. Não somente em termos de identidade da moda brasileira, mas como reverbera economicamente, de acordo com os números que este mercado movimenta.

Quando perguntadas sobre as demandas do setor, foi dito que o posicionamento (de marca) é muito importante, "primeiramente se posicionar dentro do mercado brasileiro e segundo no exterior" (Ariane) e que uma demanda constante do mercado é mão de obra qualificada, desde a facção até a costureira, segundo Milena. Perguntamos sobre o ensino de moda praia, de acordo com Milena, ele não é direcionado, apesar da importância da moda praia no Brasil:

É um segmento que não é planejado, não está na cadeia da estrutura do curso" (...) “o ensino pode falar um pouquinho de moda praia, mas não com profundidade. Eu acho que por segmento (dentro da cadeia de moda) ainda precisa se desenvolver, como a lingerie. Você não vê a moda praia e a moda fitness, são segmentos específicos que estão começando a crescer agora.

Contudo as escolas menores como IRM (Instituto Rio Moda) começam a oferecer cursos específicos para moda praia: "os espaços da moda vêm focados muito mais nos segmentos específicos do que no amplo da moda, como é o caso da escola referência de Friburgo" (do sistema S/SENAI).

Sobre empreender no segmento, segundo Ariane, "o empresário encontra muita dificuldade em conseguir mão de obra para essas demandas, para poder se fortalecer nisso" (SIC). Sobre as iniciativas para promover este segmento, as entrevistadas enfatizam que as instituições que elas representam orientam que o ensino seja articulado com a indústria, de acordo com Milena:

A gente tem desenvolvido novos cursos específicos, sempre ouvindo muito a demanda do mercado, ouvindo o que o empresário realmente precisa e a partir dessa demanda desenvolvemos cursos, palestras e projetos como essa publicação (...) a gente tem feito a ponte primeiro com o empresário, depois levamos para dentro das escolas, a gente entendeu que assim a gente ia conseguir achar o caminho". 
Sobre as dificuldades em promover este segmento foi dito que a falta de mão de obra qualificada aliada a falta de investimento em tecnologia são os pontos fracos, segundo Milena:

Uma grande dificuldade é a questão da mão de obra que você encontra, mas ela não está qualificada para o detalhe do segmento. Essa é uma dificuldade principalmente no mercado internacional de grandes acabamentos tecnológicos, peças sem costura, acabamentos de fusão, e aqui precisa retomar esse investimento, então você tem projetos de estímulo a esse tipo de investimento. Sobre a tecnologia é outro ponto.

As observações sobre as dificuldades do ponto de vista do empresário ou designer que é empreendedor pequeno são repetidas nas falas da coordenadora do curso IRM e dos designers do segmento, como Jacqueline de Biase, Thomaz Azullay.

Sobre inovação (uso de tecnologias emergentes e disruptivas), segundo Milena, o estado da arte é menos significativo se comparado com a capacidade inerente do designer brasileiro no que se refere a criatividade na parte de estamparia e modelagem:

A gente inova em termos de tecnologia, tem algum investimento, mas acho que o nosso melhor é na parte criativa, nas estampas somos número 1, somos fortes em modelagem, conforto e essa questão do life style. (Estilo de vida ligado a cultura de praia local - nota da autora)

Observa-se que as falas das entrevistadas corroboram com o que os demais participantes disseram até aqui, tanto do setor industrial, quanto do ensino de moda. $\mathrm{O}$ que poderia ser aproveitado se o diálogo entre os dois campos fosse mais efetivo. $O$ ideal seria que fosse criado um programa permanente de fomento a moda praia. Preferivelmente, se criado dentro de projetos ligados à Indústria Criativa para facilitar pesquisas de novas tecnologias e projetos integradores entre alunos e o mercado profissional.

A pesquisadora entrevistou uma designer recém-formada a fim de saber sua opinião sobre os desafios para quem está começando a projetar e empreender especificamente no segmento da moda praia. Caroline Novak foi ganhadora de um concurso de novos talentos do SENAI, a nível nacional. Os alunos escolhidos participam de uma mentoria com designers brasileiros renomados, uma espécie de imersão de conhecimentos à curto prazo. No caso da ganhadora entrevistada, o 
segmento escolhido foi o da moda praia com mentoria da estilista e empresária Lenny Niemeyer.

Perguntou-se sobre como é a busca para encontrar referências sobre moda praia, segundo Carol Novak, agora no Brasil está menos difícil encontrar essas referências: "saiu o livro o Bikini Made in Brasil," da Lilian Pacce, jornalista e apresentadora de programas televisivos de moda. Segundo a ex aluna, agora parece haver mais incentivos para o segmento: "quando eu estava na faculdade não via tanto incentivo para alguém fazer uma coleção de moda praia". Perguntou-se sobre sua opinião sobre a moda praia brasileira ser considerada um benchmark nacional. Segundo ela, tal fato seria indiferente, uma vez que, nem por isso ela sentia que havia incentivo para o segmento:

Você vai à praia e vê todo mundo com o mesmo biquíni, tanto no Sul como no Rio. Não tem inovação, acho que as pessoas podem estar querendo algo mais comercial.

Para a entrevistada, o Rio de Janeiro é uma referência para o Brasil inteiro:

As criações do Rio são inovadoras. O Rio é um lançador de tendências. Não conheço outros designers de moda praia que não sejam do Rio. Só a marca New Beach de Santa Catarina. Mas muito toda baseada no Rio de Janeiro.

A diferença para Santa Catarina (onde a designer reside) é que segundo ela, lá tem bastante indústria grande, focada no mainstream: "Santa Catarina tem muita indústria grande, não focada no design, mas na grande distribuição". Além das entrevistas com profissionais atuantes no mercado de moda, foram feitas entrevistas com estilistas que possuem algo para além do reconhecimento no setor, que de alguma forma tenham contribuído em projetos no ensino da área no design de moda. 


\section{3}

\section{A voz de designers brasileiros que atuam no mercado e na educação de moda}

Seguindo o critério da notoriedade e representatividade dos nomes de designers da moda brasileira buscou-se entrevistar os que possuíssem também inserção na área de educação. Ronaldo Fraga, Lino Linaventura e Alexandre Herchcovitch não atuam especificamente no segmento de moda praia. Eles fazem uma moda mais ampla com conceitos atrelados a discussões políticas, como é o caso da moda agênero de Herchcovitch $^{91}$ e do ativismo político de Ronaldo e Lino, críticos das questões sociais das minorias em geral.

Todas as entrevistas com os designers foram feitas no dia 25 de outubro de 2017 em um evento promovido para estimular os alunos de moda no desenvolvimento de todo o processo de criação de coleções sob a mentoria desses e de outros estilistas como a Lenny Niemeyer ${ }^{92}$. A pesquisadora utilizou como ferramenta a gravação em áudio. A transcrição foi autorizada, assim como o uso do seu conteúdo em documento assinado pelos entrevistados no momento das entrevistas. As falas foram compiladas em forma de citação com a costura dada de acordo com os objetivos de pesquisa.

\section{I - Entrevista com Ronaldo Fraga}

Quando indagado sobre a educação de moda, o estilista Ronaldo Fraga, diz enxergar um abismo na forma de se ensinar:

Eu vejo um abismo gigantesco que sempre existiu. Os tempos, os mercados estão mudando muito rápido. $\mathrm{E}$ o meio acadêmico tem dificuldades de mudar neste mesmo ritmo, acrescentar um novo formato, rever ou criar uma nova cadeira demora muito.

\footnotetext{
${ }^{91}$ Sobre este tema a pesquisadora publicou um artigo com co-autoria de Fernanda Coutinho e Denise Portinari na Revista Dobras em 2018. A discussão central traz a questão da normatização e da resistência, assunto tratado nesta tese. O link para o artigo se encontra no site da Revista Dobras intitulado: "Moda agênero, uma proposta de moda que desconstrói as barreiras de gênero? ". Fonte: https://dobras.emnuvens.com.br/dobras/article/view/715 acesso em 17 de março de 2019.

92 No caso da Lenny, por já ter contribuído com a pesquisadora em outra ocasião, nessa ela não foi entrevistada, mas utilizamos trechos da sua contribuição anterior.
} 
Ao ser perguntado sobre se os alunos saem preparados para o mercado de trabalho, Ronaldo é categórico:

Claro que não. O Senai do Rio ainda tem uma estrutura melhor. Mas tem um trabalho ainda pela frente que precisa melhorar, um longo caminho para melhorar. O presente está uma bosta (SIC). Os tempos mercantlilizados. Depois que as escolas de moda da Europa foram compradas pelos americanos tudo virou uma coisa só.

Segundo Ronaldo, o descompasso entre a educação e a indústria impacta o mercado de trabalho também:

Tem que acrescentar um novo formato (de ensino), rever ou criar uma nova cadeira demora muito, temos visto muita gente indo para o mercado e não conseguindo emprego.

Corroborando com a fala da ex-aluna Caroline, os alunos não estariam saindo das escolas de moda bem preparados, "o ensino de moda no Brasil está totalmente atrasado" - declarou o estilista.

\section{II - Entrevista com Lino Vilaventura}

Ao estilista Lino Vilaventura perguntou-se como ele enxerga a relação do ensino com a indústria atualmente. Segundo o estilista o ensino técnico é importante para quem deseja empreender ou trabalhar em empresas do setor:

Acho muito importante termos o ensino técnico, principalmente quando estes futuros profissionais serão encaminhados para a indústria. Trabalhar com moda tem dois caminhos. Você pode desenvolver um trabalho direcionado para uma grande marca, ir para a indústria, ou realizar um trabalho mais autoral. O conhecimento técnico funciona para os dois caminhos. Obter um entendimento sobre o produto, como funciona o básico, como chega ao mercado, como se comunicar com o consumidor.

Sobre se ele considera recém-formados que chegam para o mercado preparados para atuarem profissionalmente, Lino acha que não: "somente na prática se adquire a experiência necessária, a escola oferece o direcionamento".

O estilista acredita que os cursos de moda em geral oferecem o básico, mas "só no dia a dia ganha-se know-how: você precisa direcionar a carreira quando está no mercado para criar sua identidade própria". 
Segundo Lino, os recém-formados que desejam ter um negócio próprio, empreender na moda também sentem dificuldades, neste quesito precisam de incentivos constantes para se sentirem seguros. Para Lino, existem vários tipos de profissionais que saem da faculdade, "um mais técnico outro mais criativo".

Lino considera a moda praia feita no Brasil uma forte referência internacional. Diz que temos boas marcas que são muito criativas e embora ele não trabalhe no segmento, sente que as dificuldades de trabalhar moda praia no Brasil sejam as mesmas de quem trabalha com moda em geral.

\section{III - Entrevista com Alexandre Herchcovitch}

Perguntamos sobre como o estilista Alexandre Herchcovitch enxerga a relação entre o ensino e a indústria. Alexandre acredita que as faculdades estudam o mercado e "acabam oferecendo os cursos que as empresas precisam". Contudo, segundo o designer, escola e trabalho são mundos bem diferentes, em qualquer profissão: "a escola não consegue fornecer para o aluno com perfeição o que ele vai enfrentar lá na frente".

O designer enxerga a moda praia brasileira como consequência da geografia do país, que possui muitas praias, com isso, proliferam marcas especializadas. Repete que o aluno de design que deseja trabalhar em qualquer área precisa ter experiência real no mercado, pois é a prática que vai ensinar.

No caso da moda praia, é sabido que a escola precisa de uma estrutura de maquinários especiais para o ensino de corte, costura e na parte de modelagem, por exemplo. Existe uma dificuldade em trabalhar com bases e medidas exatas, uma vez que como mencionado anteriormente, cada empresa desenvolve suas bases e padrões.

Segundo Alexandre as escolas preparam melhor o aluno na "parte conceitual, quando é estilo eles chegam preparados". Contudo, para o estilista, a educação é mais “aderente" quando o conteúdo é mais prático: "nos casos mais práticos, mais matemáticos, como modelagem, costura".

$\mathrm{Na}$ visão do designer, "a escola não consegue prever o que os alunos vão encontrar pela frente, pois cada empresa é diferente". Possivelmente projetos como o 
que será detalhado no capítulo 5, de aproximação entre escolas e empresas, facilitariam a inserção dos alunos no mundo do trabalho: "a escola tenta mostrar para o aluno o cenário de trabalho, mas a realidade é diferente”, diz Alexandre Herchcovitch.

\section{4}

A voz de profissionais do setor da moda do segmento de moda praia do Rio de Janeiro

A pesquisadora fez visitas técnicas a fim de conhecer os setores e o funcionamento das fábricas - em especial que produz biquíni. A empresa escolhida para o relato nessa tese foi a Salinas, hoje parte do grupo Inbrands que detém o controle de outras marcas de moda. A base de produção fica concentrada no mesmo local junto com a equipe de estilo, designers, engenheiros de produção, estoque dentre outros no Rio de Janeiro.

Algumas etapas da produção normalmente são terceirizadas, como é o caso da marca carioca que também funciona no mesmo local em São Cristóvão, a Richards. No caso da moda praia da Salinas, a pesquisadora teve acesso a todos os setores, conversou com funcionários, entrevistou, registrou em vídeo e fotos o processo em 16 de agosto de 2017.

A funcionária Maria Elena, do setor de corte relatou que a maioria dos funcionários aprendia suas funções dentro da própria empresa. Geralmente são pessoas que ficam muito tempo na empresa e a medida que vão aprendendo novas funções vão mudando de postos. Maria Elena, diz que seria muito importante se os funcionários tivessem cursos dentro das empresas. Segundo ela, a modelagem seria fundamental, junto com o programa CAD que atualmente é muito usado dentro das empresas.

As novas tecnologias que surgem facilitariam muito a vida dos profissionais. Contudo, seria importante que tivessem treinamentos adequados. A funcionária Vera, da área de risco (do verbo riscar) trabalha com programas digitais (Moda 1, que é um CAD). Ela traduz o que a modelista coloca no papel com as dimensões exatas em um formato digital para a saída em uma máquina que imprime no papel as modelagens, em 
tamanho real. Depois dessa etapa, a modelagem impressa em papel segue para o setor de corte.

Ao perguntar à Vera sobre qual o grau de facilidade/dificuldade para se encontrar pessoas com capacitação para desenvolver a mesma função dela, Vera responde achar ser fácil, pois ela já está há mais de 20 anos na mesma empresa e aprendeu lá mesmo a usar as ferramentas digitais.

Todo processo de modelagem, pilotagem, costura, risco e corte são acompanhados pelos profissionais envolvidos nos respectivos setores. Eles trabalham de uma forma transversal, ou seja, há um diálogo entre os setores de acordo com cada etapa do trabalho em que os processos que vão se materializando em papel riscado, corte, peça costurada etc. Cada etapa é supervisionada pelas equipes criativas e pelos responsáveis pela gestão de processos e engenharia têxtil/produção.

Essa forma integrada de trabalhar funciona em cadeia pois já está sistematizada dentro dos tempos (na indústria têxtil existe uma metodologia para mensurar essa parte do processo) e modos de gerir uma indústria. O trabalho é setorizado, mas não é fragmentado, diferente de como ocorre nas escolas de moda em geral em que os alunos aprendem conteúdos fragmentados em disciplinas, conforme dito no capítulo sobre o ensino de moda.

A comparação entre a forma das equipes se relacionarem em um mesmo ambiente de trabalho, composto por células para diferentes áreas que se interligam, nos remete à interdisciplinaridade no quesito da troca e comunicação entre elas. A maneira de ensinar não corresponde de fato a maneira de trabalhar no exemplo proposto.

Para que o leitor tenha uma referência visual de sobre o funcionamento de uma indústria de moda praia, inserimos algumas imagens da visita abaixo. Tais imagens mostram alguns dos setores que funcionam simultaneamente em um mesmo local permitindo a comunicação e coordenação dos processos de forma transversal. 

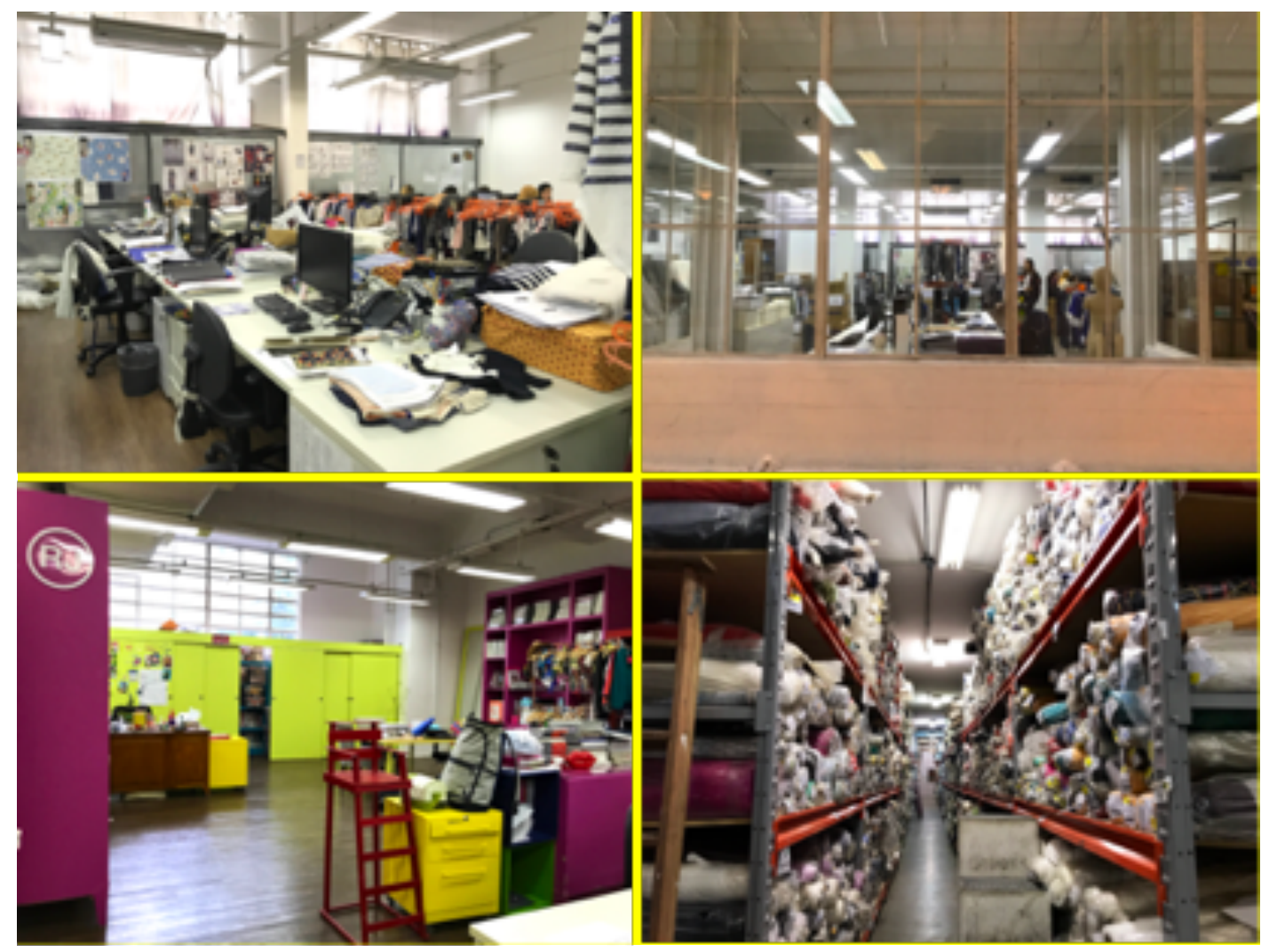

Figura 7: Etapas do funcionamento de uma indústria de moda praia.

A responsável pela gestão de compras, negócios e produção, Adriana Priori, trouxe a reflexão sobre a necessidade de profissionais com maiores responsabilidades como é o caso dela, que ocupa um cargo de maior confiança também terem mais opções e acesso à cursos e capacitações. No caso, o interesse seria nos cursos mais práticos e técnicos para entenderem, de maneira panorâmica, um pouco das outras funções dos funcionários que trabalham nos setores de modelagem, corte, risco e costura. Essa proposta aproximaria as equipes em diversos níveis e em termos de linguagem, como por exemplo para solução de problemas que requerem diversos conhecimentos como é no caso da gestão de processos/compras etc.

Segundo Adriana, se as escolas de moda forem para as empresas e para o "chão de fábrica" com cursos desenhados especialmente para atender a demandas específicas de cada empresa, isso facilitaria muito a vida dos profissionais que precisam de uma reciclagem. Contudo, a maneira de ensinar também teria que ser adaptada, uma vez que a linguagem em sala de aula, a disponibilidade de tempo e espaço mental para dividir 
entre o trabalho a ser realizado e novos conhecimentos é diferente em cada ambiente e etapa de vida.

Ainda segundo Adriana, além do ensino focado nas capacidades técnicas, os funcionários também deveriam aprender um pouco de gestão e liderança. Segundo ela, há uma grande dificuldade em fazer com que os núcleos de trabalho dentro de cada atividade tenham uma pessoa responsável com atitude de liderança. Isso ocorre, porque segundo a gestora, os funcionários não respeitam alguém que seja hierarquicamente do "mesmo nível", quando este assume uma responsabilidade maior como por exemplo, de coordenação da equipe.

Tal problema poderia ser trabalhado desde o ensino, seja ele técnico ou superior de moda. A dificuldade é tanta que nem os próprios funcionários se sentem à vontade quando são escalados para funções de liderança. Tais capacidades, se melhores trabalhadas em sala de aula, facilitariam o convívio entre os funcionários - e isso impactaria positivamente na produção, uma vez que, segundo a entrevistada, os funcionários são resistentes aos "líderes de células". Ocorre também de ao aceitarem exercer essas funções, os outros funcionários boicotariam a produção intencionalmente.

Sobre a necessidade de investir em uma educação que abranja aspectos comportamentais, de acordo com a colocação da entrevistada, cabe aqui uma reflexão acerca das mudanças que já estão ocorrendo com base em uma visão de "indústria 4.0". Com as indústrias cada vez mais investindo em um ambiente automatizado, robotizado, com tecnologias que se comunicam através de multiplexagem em um ambiente híbrido humano-cibernético, as capacidades de gestão e as chamadas soft skills serão cada vez mais requeridas, uma vez que o perfil profissional cada vez mais demanda um conhecimento mais complexo. Além da capacidade do profissional em conseguir transitar e se comunicar entre pessoas e máquinas.

Outra questão ligada a cultura das empresas de moda em geral é de conseguir fazer com que funcionários antigos, que aprenderam suas funções no próprio trabalho, tenham respeito com os novatos. Muitas vezes, eles chegam sem experiência do "chão de fábrica", mas com o aprendizado formal ensinado nas escolas. Tal ensino é permeado por inovações e conhecimentos que se relacionam com as novas tecnologias, 
mas a falta de experiência prática coloca em xeque seu rendimento e desempenho que um funcionário antigo domina.

Idealmente, a troca entre os dois seria valiosa, mas geralmente o antigo funcionário resiste a trocar com o novo, deixando de aprender e ensinar. Ao perguntar sobre como profissionais mais experientes conseguem aliar suas práticas com as tecnologias emergentes ou disruptivas, Adriana foi categórica:

"Modelista boa é modelista velha (SIC). Bato palma, porque elas aprenderam (a usar programas como CAD). Porque ela já fez, já errou, já fez de novo. Minha modelista das roupas, ela faz tudo, tem 60 anos. Ela não sabe ler e-mail. Como eu vou fazer essa pessoa mexer num software? Então esse é o problema. Eu posso trazer pessoas mais jovens, mas elas não têm experiência, aí o perigo. Se fossem peças simples que a gente faria, ok. Mas não são peças simples. Como fazemos uma pessoa que tem todo o know-how fazer no computador? O ideal é juntar a experiência com o saber usar o computador. Mas é difícil. Qual empresa vai contratar duas pessoas para o mesmo trabalho? Todo mundo mexe no CAD, mas a modelista não. Ela faz no papel e entrega pra pessoa do CAD que digitaliza. A ideia é não ter a pessoa do CAD e a modelista fazer direto no CAD. O desafio é esse, o desafio do mercado (de moda como um todo). Formar as pessoas que estão aprendendo modelagem e a usar o CAD. Temos que esperar até elas terem experiência de mercado".

Com o objetivo de dar ao leitor uma dimensão mais exata de como foi a experiência no chão de fábrica, foram escolhidos alguns registros de imagens do processo da produção feita manualmente e com auxílio de máquinas. Após passarem pelas etapas de: criação/ estilo, modelagem manual, modelagem digital, corte, pilotagem, análise de qualidade, prova (com modelos de prova para diagnóstico de possíveis erros no caimento, vestibilidade e conforto), dentre outros processos, até chegar na produção em escala pronta para distribuição. 

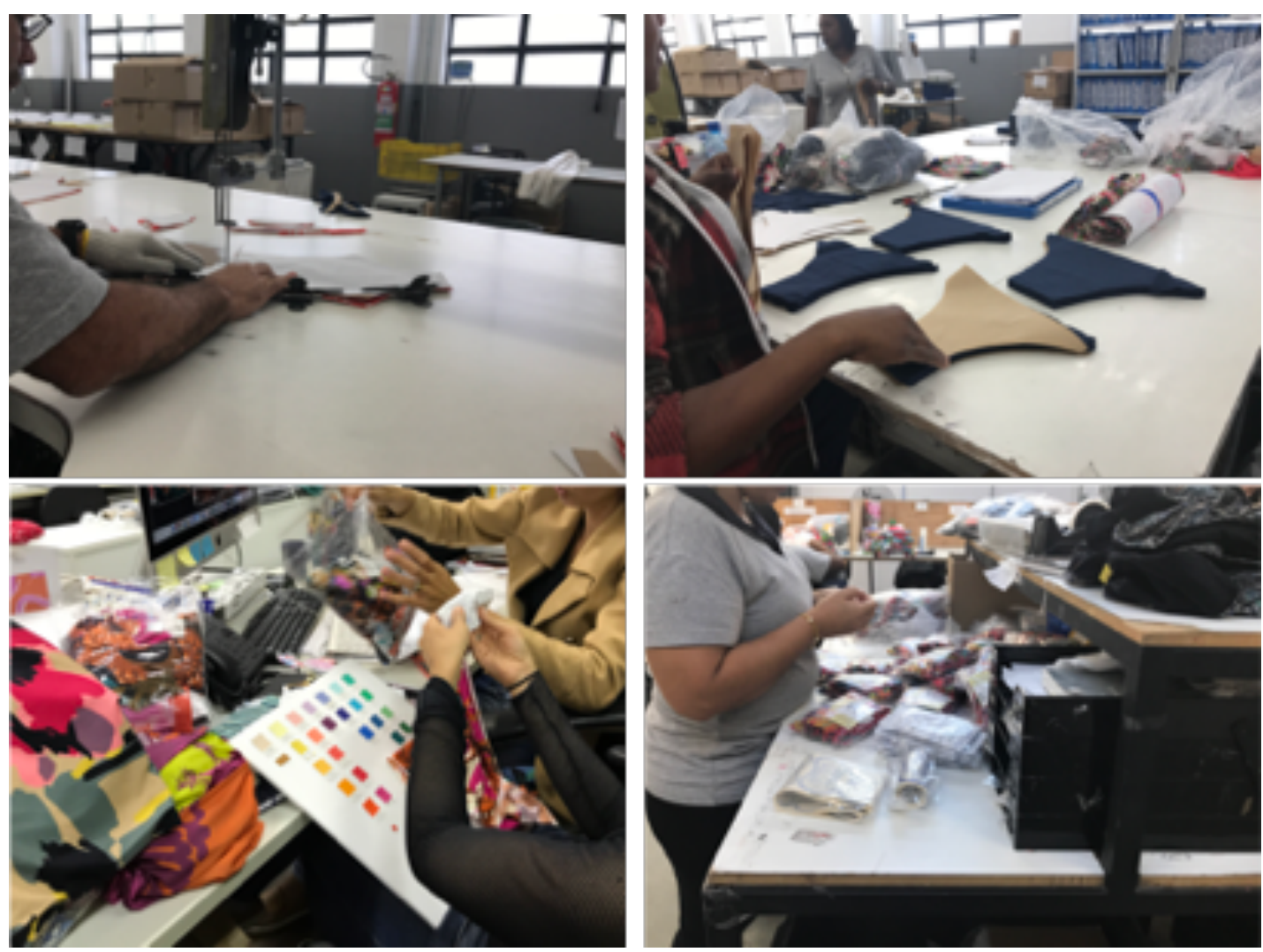

Figura 8: Indústria de moda praia funcionando com setores interligados

A imersão no chão de fábrica de uma indústria de moda praia permite uma reflexão também sobre a importância dos novos currículos contemplarem conteúdos ligados ao "comportamental" - segundo definição dos representantes da indústria. A terminologia soft skill abrangeria desde as habilidades inerentes ao convívio em equipe, que inclui capacidades como resiliência, empatia, participação, comunicação e inteligência emocional. Até a capacidade criativa, de aplicar as habilidades técnicas as hard skills, aos diversos contextos de trabalho, sabendo escolher e facilitar a eleição de líderes para cada atividade. 


\section{5}

\section{A voz de representantes da Indústria da moda}

Seguindo os critérios de representatividade e notoriedade para ouvir a voz de representantes da indústria buscou-se ouvir também os nomes por traz da estrutura maior dentro da cadeia têxtil: os grandes fornecedores de insumos/matéria prima e os reguladores (associações e sindicatos) do setor. Para tal, primeiramente fizemos contato com os atores da indústria previamente escolhidos, de acordo com os critérios de notoriedade no setor e das oportunidades que a pesquisadora buscou para que houvesse interesse e compromisso na colaboração com esse trabalho. Os questionários foram enviados via e-mail, após um primeiro contato presencialmente com os participantes dessa etapa.

\section{Rosset por Oswaldo de Oliveira}

Em outubro de 2017, o físico e engenheiro mecânico Oswaldo de Oliveira Filho respondeu a um questionário com perguntas pertinentes ao tema de pesquisa. $\mathrm{O}$ contato se deu devido ao fato de Oswaldo trabalhar na indústria da moda, especificamente na área de produção de tecidos com fios de Lycra na Rosset, pioneira e líder no segmento. A fim de manter a fidedignidade do conteúdo e, ao mesmo tempo, estabelecer uma ligação com o restante do trabalho, destacamos as passagens a serem comentadas no final do questionário.

\section{1- Como você enxerga a relação entre ensino e indústria atualmente?}

Depende do ramo. Há uma profícua relação entre o Senai SP e a indústria automobilística. Vejo também uma importante simbiose entre a indústria farmacêutica e a academia. No têxtil e no vestuário é algo tênue, não sistemático e até um pouco distante.

\section{2- Quais os impactos da aproximação entre ensino e indústria no setor têxtil / vestuário?}

O principal é a economia de horas de treinamento interno (dentro das empresas/fábricas - nota pesquisadora). A rotatividade (na área) têxtil é mínima, então vou ignorar. No vestuário, as áreas de "moda", também apresentam baixa rotatividade, mas ainda encontram profissionais, provenientes do ensino, com algum conteúdo específico, porém, nas áreas técnicas, especialmente costureiras e instrutoras, as empresas têm sido 
obrigadas a investir expressivos volumes em treinamento básico. Ainda que o Senai possua cursos nessas áreas, esses alunos, em geral, não estão chegando às indústrias.

\section{3- Pensando na moda praia como benchmark nacional:}

\section{a) Como você vê os profissionais recém-formados?}

A moda praia brasileira, de fato, é extremamente respeitada e reconhecida como parte ativa do DNA do Brasil. As escolas têxteis e de "moda" brasileiras possuem um intenso viés algodoeiro. Neste sentido, formam profissionais com conhecimentos químicos bem superficiais e baixa habilidade com a ampla matriz de tecidos sintéticos, especialmente os tecidos elásticos.

\section{b) eles (alunos de moda) chegam preparados para atuar no setor?}

Desconsiderando, eventualmente, o pessoal de criação, que pode compartilhar alguns conceitos de moda, como a estamparia, os profissionais técnicos acabam aprendendo, apenas na prática, as variáveis específicas do setor, tais como: módulo de elasticidade (lei de Hooke), deflexão, histerese, elasticidade residual, força de retorno, alongamentos, viés elástico (utica), medidas e tolerâncias em produtos elásticos (tecidos, forros, laizes). E também, como os efeitos combinados dessas variáveis do tecido base e dos forros, que são diferentes, impactam na modelagem e na montagem da peça final. São, portanto, conhecimentos muito específicos e essa especificidade reflete-se também nas técnicas de corte e nos equipamentos de costura.

\section{4- Você enxerga alguma iniciativa para aproximação entre ensino e indústria no segmento de moda praia?}

Este trabalho (CTS - Comitê Técnico Setorial, SENAI - nota da pesquisadora) democrático que realizamos nesses dois dias foi uma iniciativa importante. Ali se percebeu alguma distância entre aquilo que se acredita real e a realidade de fato. Espero que essa discussão não se encerre, como previsto, porque não houve tempo de se tratar temas técnicos com a necessária profundidade para produzir efeitos notáveis nas grades curriculares.

\section{6- O conhecimento em torno da moda praia está disponível para quem deseja projetar? (Para o designer).}

Acredito que a base criativa mora na própria exuberante, rica e diversificada natureza sócio geográfica do Brasil. Esta é a fonte de inspiração mãe. A partir daí, as técnicas de estamparia criativa são bem abordadas pela moda, bem como as paletas e formas dominantes e suas tendências. Acho que não vai muito além disso.

A partir da modelagem já não se encontram informações que resolvam a teia de especificidades das matérias envolvidas. São técnicas que hoje são adquiridas dentro das indústrias do ramo e demandam um tempo de treinamento e adaptação. A "designer" 
autônoma sempre pode evoluir nessas técnicas, mas usando abordagens experimentais de tentativa e erro.

\section{7- O conhecimento em torno da moda praia está disponível para quem deseja empreender?}

O empreendedorismo tem um sentido amplo então, diante da resposta anterior, o empreendedor pode sim ter sucesso nesta atividade contratando um ou dois profissionais técnicos experientes. Como empreendedor individual seria recomendável estágio em Industria do ramo para reduzir os riscos das tentativas. Quanto à formação administrativa, para esta não faltam cursos, alguns com excelente visão pratica.

\section{8- Na sua visão, quais os possíveis impactos da chamada indústria 4.0 no segmento da moda praia?}

Muito do que foi exemplificado como indústria 4.0, na realidade, é um pouco "mais do mesmo", ou seja, ao invés da costureira conduzir as partes sob uma linha que sobe e desce, tem um braço mecânico, ao invés da informação fluir por papel ou por cabo, ela flui pelo ar, ao invés da fábrica estar a $50 \mathrm{~km}$ ela está a 5 metros. Sinceramente, sem soluções disruptivas. Nós temos máquina Lectra, código de barras e e-commerce desde 89. Faz 5 anos comprei 2 máquinas de RFID e até hoje não há tecnologia de etiqueta e antena que viabilize seu uso. Apenas uma evolução disruptiva de fato como a multi nano-impressora 3D doméstica poderá causar impactos à esta indústria, tal como ela se apresenta hoje e há 3000 anos.

Comentário (nota do respondente no corpo do e-mail):

Eu sou um admirador da academia e sei das importantes contribuições que o ensino e as pesquisas podem trazer ao mundo empresarial. Espero que esta dinâmica que fizemos tenha revelado a necessidade de se repetir de forma sistemática e frequente, essa aproximação com a indústria.

Sobre a fala do representante da Rosset, pode-se fazer um paralelo com a entrevista realizada no chão de fábrica da marca Salinas. De fato, a distância entre ensino e indústria fica evidenciada mais no nível dos profissionais técnicos. Nas áreas cujo enfoque é criação e estilo, a formação superior em design (e também marketing) é mais abrangente. É vista como mais satisfatória por parte dos atores representantes da indústria desta pesquisa.

Segundo Oswaldo, o diferencial competitivo na moda praia está na criatividade ligada a natureza e geografia do Brasil. Em outras palavras, a influência da cultura de 
praia. Ele cita também capacidades que o designer desenvolve, deixando a crítica para o ponto fraco: a parte técnica que demanda referências (modelagem por exemplo).

Por fim, considera que a fala sobre o uso de tecnologias disruptivas com base no conceito proposto de indústria 4.0 foi no sentido de desconstruir o discurso vigente, em torno de uma mudança que ainda não é efetiva nos modos de produção. $\mathrm{O}$ investimento em tecnologias de ponta incluiria a mudança no ensino em todos os níveis, para formação de profissionais aptos ao uso de tais tecnologias. Incluiria também a mudança de toda uma cultura empresarial, de novas práticas de investimentos de riscos (menos conservadores em se tratando de disrupção), assim como incluiria a adesão em cadeia de tais práticas em todo o setor da moda no Brasil. De certo modo, em alguns segmentos como o automobilístico a indústria já opera em um formato mais automatizado, robotizado etc. Na moda, a realidade é diferente, envolve outras variáveis, outro modus operandi.

\section{A voz de representantes da Indústria da moda, ABIT}

O contato com o representante da ABIT, ocorreu entre os meses de outubro e novembro de 2017. Além da participação no CTS, Sylvio Napoli enviou por e-mail um documento da consultoria do IEMI, sobre o Mercado de Moda Praia no Brasil. O documento, usado no capítulo 2, apresentou projeções sobre a produção, o consumo e tendências econômicas da moda praia nos mercados internos e externos. Segundo Sylvio Napoli a relação entre ensino e indústria ainda é tímida mas tem melhorado:

De 5 anos para cá parece que isso está se modificando para melhor graças a abertura de diálogo das duas partes. Mesmo sem muita ação do governo que deveria agir de forma muito mais pró-ativa. Penso que se percebeu que sem sinergia não se maximiza este relacionamento, apesar de reconhecer que essa atitude não ocorre somente com a cadeia Têxtil, mas é uma tendência nacional, salvo honrosas exceções.

Acho ainda tímida a aproximação nos dias de hoje, os cursos já deveriam ser dirigidos desde o início com a constituição de conselhos de empresas ligados diretamente às escolas de formação para seguirem os passos dos estudantes desde o início dos cursos até a inserção dos formandos no mercado de trabalho.

Segundo Sylvio, a aproximação entre os campos deve contemplar novas demandas: 
Os impactos desta aproximação devem ser extremamente benéficos, haja visto a imperiosa necessidade de adaptação dos cursos voltados ao vestuário e têxtil visando a chegada inevitável e bem-vinda da indústria 4.0. Profissionais recém-formados estão muito voltados às ciências da computação, sem no entanto, terem muito contato com aspectos de gestão de negócios, relações interpessoais e até aspectos políticos em geral. Outro aspecto importante é o balanceamento correto entre oferta de profissionais novos e demanda do mercado pois poderá acarretar super oferta e causará certamente frustração nos novos profissionais na hipótese do mercado não os absorver.

Sobre a moda praia, Sylvio fala dos aspectos conceituais, da necessidade em aliar pesquisa (viagens, mercados, editoriais) com incentivos do governo e enxerga que o conceito de indústria 4.0 vai impactar o segmento da moda praia93:

Penso que o conhecimento em torno da moda praia seja abrangente desde que as escolas mantenham contatos frequentes com grandes editores de moda mundiais e promovam constantes viagens técnicas à mercados consumidores. Penso que deveria ser estreitado o relacionamento com organismos do governo voltados aos mercados interno e externo, e isso se aplica tanto às empresas como aos empreendedores.

Os impactos da indústria 4.0 no segmento da moda praia como de resto em qualquer outro sub-segmento de confecção será muito profundo tanto na parte da confecção como na concepção de produtos pois é um segmento que tem tudo a ver com aspectos de origem psico-sociais e mutantes em relação aos movimentos humanos, inclusive na relação com aspectos físicos e médicos.

Vejo neste seguimento uma excelente oportunidade para o Brasil se projetar mais ainda no cenário internacional pois já é uma fonte muito forte nas exportações têxteis brasileiras.

Considero também indispensável o conhecimento dos profissionais entrantes no mercado, das tecnologias têxteis que irão fornecer a matéria prima e o processo de obtenção dos produtos de moda praia e fitness evitando que muitas inovações se percam pela inexistência de condições técnicas de obtê-las.

\section{6 Representantes da indústria da moda falam do ensino oferecido no Brasil}

A experiência da pesquisadora na participação do diálogo entre atores da educação e da indústria é aproveitada no sentido de dar oportunidade de uma reflexão em cima de um encontro que visa estreitar a relação entre as duas esferas. Nesse

\footnotetext{
${ }^{93}$ As conclusões desse subcapítulo serão condensadas no final do capítulo 4 e no 6.
} 
sentido, buscou-se narrar "como e porquê" o encontro acontece, e quais as impressões colhidas sobre as narrativas dos atores envolvidos.

Esse diálogo ocorreu, a partir de uma metodologia própria de ensino para acompanhar e atualizar os currículos dos cursos oferecidos em âmbito nacional pelo SENAI Nacional. Os convidados receberam o convite (carta via diretoria do SENAI CETIQT) com os seguintes termos:

A partir da necessidade de aprofundar o entendimento das demandas da Indústria Têxtil e de Confecção, o SENAI CETIQT, junto com o SENAI Departamento Nacional (DN), formará um Comitê Técnico Setorial Nacional da área do Vestuário, visando levantar as demandas das empresas do setor por perfis profissionais aderentes às suas necessidades. O objetivo do SENAI é o de atender a essas demandas em suas ações de educação profissional, tanto no ensino técnico quanto no ensino superior.

Nesse sentido, temos o prazer em convidá-lo para integrar o Comitê Técnico Setorial Nacional da área do Vestuário.

Os Comitês Técnicos Setoriais Nacionais são constituídos por especialistas reconhecidamente competentes do respectivo setor tecnológico (das indústrias, do meio acadêmico e do SENAI), especialistas em pesquisa (do meio acadêmico e do SENAI), especialistas em educação profissional (do SENAI), além de representantes do governo e dos respectivos sindicatos de empregados e empregadores e/ou associações.

Por meio desta ação, o SENAI busca ampliar as possibilidades de cooperação e integração com o setor produtivo, promovendo a discussão e a identificação conjunta das demandas por perfis profissionais que embasarão a (re)formulação dos currículos dos cursos a serem ofertados nos diferentes níveis e modalidades de formação.

A discussão a ser desenvolvida no CTS será acerca das competências e perfis profissionais demandados pelas empresas, considerando as necessidades atuais, as tecnologias emergentes e a sua difusão no referido setor industrial.

A efeito de maiores esclarecimentos ao leitor, sobre os objetivos da instituição em questão, buscou-se uma definição, de acordo com o documento de projeto pedagógico do SENAI CETIQT, versão de 2015:

O SENAI (Serviço Nacional de Aprendizagem Industrial) é uma das entidades que compõem o "Sistema S", ou serviços sociais autônomos, entidades de caráter privado e sem fins lucrativos, incentivadas por meio de recursos oriundos da indústria. Criado pela Confederação Nacional da Indústria (CNI), em 1942, para atuar nas áreas de educação profissional e prestação de serviços técnicos e tecnológicos, atualmente, o SENAI é considerado o maior complexo de educação profissional e tecnológica da América Latina, qualificando mais de 3,0 milhões de trabalhadores brasileiros a cada ano.

O SENAI apoia empresas em 28 áreas industriais por meio de um Departamento Nacional, 27 Departamentos Regionais e unidades operacionais instaladas nos 26 Estados e no Distrito Federal. O SENAI CETIQT (Centro de Tecnologia da Indústria 
Química e Têxtil) atua como centro de tecnologia e formação profissional para a Cadeia Têxtil e de Confecção do país.

Apesar do SENAI estar presente em diversas regiões do Brasil, o SENAI CETIQT possui particularidades que o diferenciam de outras escolas do "sistema S", sendo considerado indutor de pesquisas e inovação. De acordo com o mesmo "documento pedagógico", a instituição é definida da seguinte forma:

O SENAI CETIQT oferece cursos de Graduação, Pós-Graduação e Extensão, além de Serviços Técnicos e Tecnológicos às empresas que formam a cadeia têxtil e de confecção e desenvolve Estudos e Pesquisas a diferentes setores da Indústria. Também opera em uma Unidade na Barra da Tijuca, desde 2004, e no presente momento funciona de modo integrado com a Unidade Riachuelo.

O Centro de Tecnologia da Indústria Química e Têxtil - SENAI CETIQT, localizado no Rio de Janeiro, é hoje a única unidade operacional ligada ao Departamento Nacional do SENAI e é responsável pela formação profissional e a prestação de serviços orientados à cadeia produtiva dos setores têxtil e de confecção. Por meio de seus projetos e processos, o SENAI CETIQT busca elevar a competitividade industrial, promovendo o crescimento da indústria.

O SENAI é uma instituição de interesse público, sem fins lucrativos, com personalidade jurídica de direito privado e está fora da Administração Pública, sendo hoje sua missão: "Promover a educação profissional e tecnológica, a inovação e a transferência de tecnologias industriais, contribuindo para elevar a competitividade da indústria brasileira".

A Faculdade SENAI CETIQT possui estrutura de destaque, com plantas-piloto que reproduzem o ambiente fabril, planta piloto de confecção, rede integrada de laboratórios e uma área de Inovação, Estudos e Pesquisas, com foco em antropometria, comportamento e consumo, cor, design, economia criativa, prospecção tecnológica e mercadológica, sustentabilidade e responsabilidade socioambiental.

Embora a vocação maior do SENAI no restante do país esteja associada aos cursos técnicos profissionalizantes, o CETIQT tem como diferencial o curso superior de design de moda e cursos de pós-graduação em diversas áreas da indústria da moda.

A proximidade com a indústria tendo sido criado para atender suas demandas, faz com que a instituição esteja sempre atualizando os cursos com base nas necessidades e mudanças ocorridas no setor. Dessa forma, a política da instituição é atualizar e reformular seu portfólio de cursos presenciais e a distância "ampliando as modalidades de ensino de forma a abranger diferentes níveis de formação, cargas horárias, programas de governo, necessidades de pessoas físicas e jurídicas e novas tendências do mercado têxtil e de confecção". 
Ao longo do desenvolvimento desta tese, por conta do tema tratado, a pesquisadora foi convidada a participar do projeto já mencionado para o redesenho do portfólio dos cursos do SENAI CETIQT. O projeto, realizado com o SENAI nacional, envolveu profissionais de várias regiões do Brasil das "duas pontas": representantes da indústria e acadêmicos da área de moda.

A pesquisadora participou de várias etapas do projeto iniciado no Rio de Janeiro e depois em Brasília, tendo como atividade principal realizar estudos prospectivos sobre o contexto da educação de moda nos seus diversos níveis (técnico, profissional, superior, especializações). O contexto para o estudo teve enfoque nas novas tecnologias disruptivas que impactarão o setor de moda, a revolução 4.0, que aprofundaremos mais adiante, nos capítulos 5 e 6 . A pesquisadora também participou de reuniões de NDE (núcleo docente estruturante) e de eventos com designes de moda, que deram origem a algumas entrevistas.

A segunda etapa do projeto, após estudos internos e pesquisas sobre o contexto da educação no setor, foi com base na metodologia dada pela instituição para a realização do contato com os representantes da indústria, da seguinte forma:

1. Foram traçados os critérios para a escolha dos nomes dos representantes da indústria com base na notoriedade das empresas que eles representam e de seus cargos/funções;

2. Com uma listagem da amostragem verificou-se se havia um equilíbrio em termos de representatividade de cada função e setor. O ideal seria uma amostra heterogenia com nomes que contemplassem áreas de gestão com contato com o chão de fábrica e de diferentes setores: varejo, indústria, sindicatos, associações etc.;

3. O tamanho da empresa também foi um critério. Foram escolhidas de grande porte e com abrangência nacional (marcas, fornecedores, varejistas);

4. $\quad \mathrm{O}$ contato ocorreu durante os dois meses que antecederam o evento. Uma carta foi enviada e em seguida com a confirmação dos nomes, foram tomadas as providencias para realização do encontro (emissão de passagens aéreas, hospedagem, organização etc.). Durou 2 dias em um grande hotel no bairro do Flamengo.

5. A reunião contou com a coordenação das equipes do SENAI CETIQT, tendo a pesquisadora como coordenadora técnica da área do vestuário (moda). Em 
conjunto com coordenadores metodológicos do SENAI nacional que vieram de Brasília para conduzir o diálogo com os convidados.

6. O diálogo com a indústria foi pautado com base nos documentos da metodologia SENAI e no contexto de trabalho do perfil profissional (possíveis saídas para o mercado de trabalho, principais meios de produção, métodos e técnicas de trabalho, condições de trabalho, evolução da ocupação, mudanças nos fatores tecnológicos, organizacionais, econômicos e nas atividades profissionais).

Para dar ao leitor uma referência sobre como o encontro é realizado, as imagens abaixo mostram um pouco da apresentação do CTS e do grupo de trabalho formado com os convidados da indústria e com os convidados do ensino, nesta etapa em um momento mais passivo de escuta.

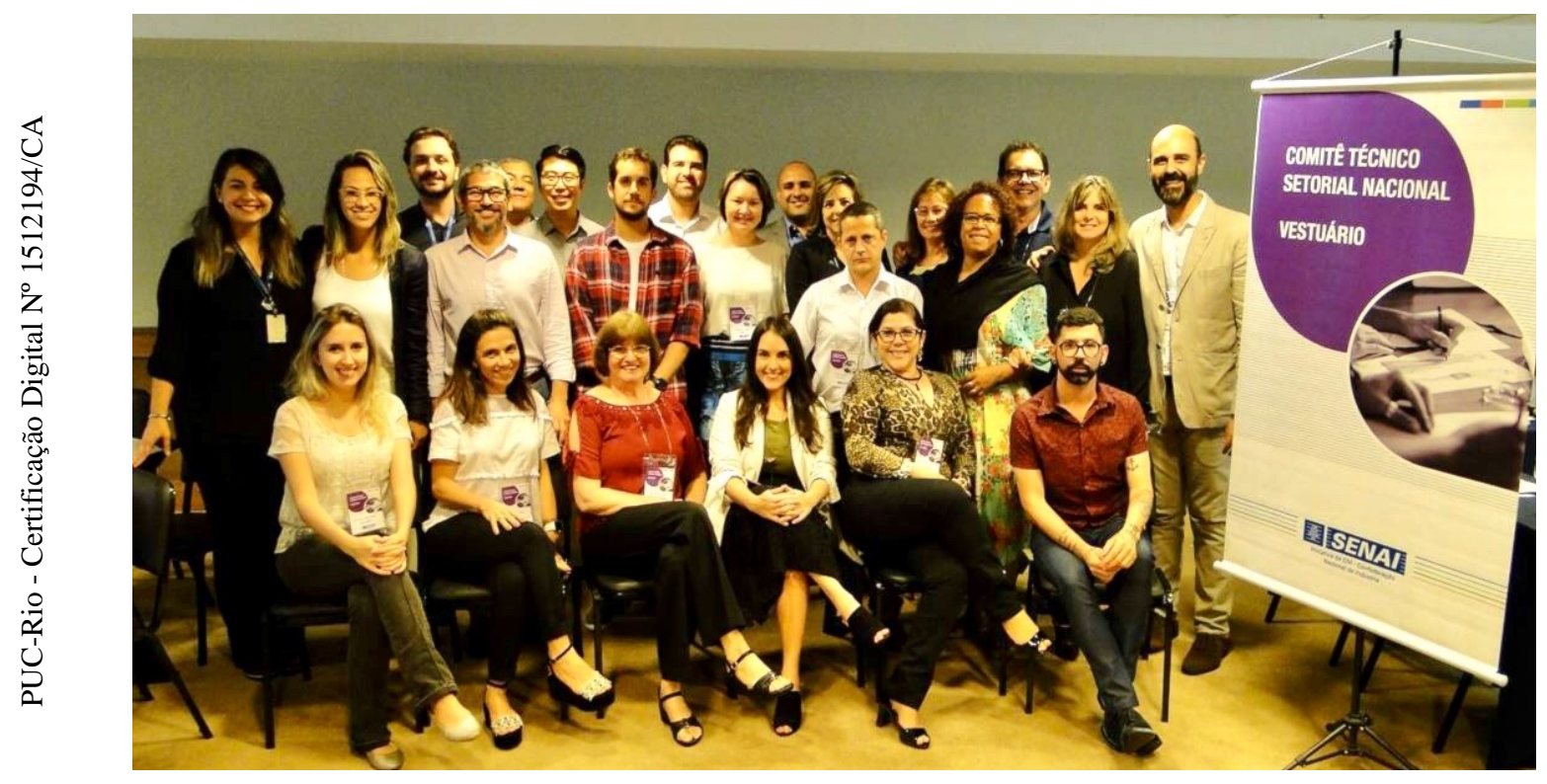

Figura 9: Apresentação da metodologia do CTS para os representantes do ensino 


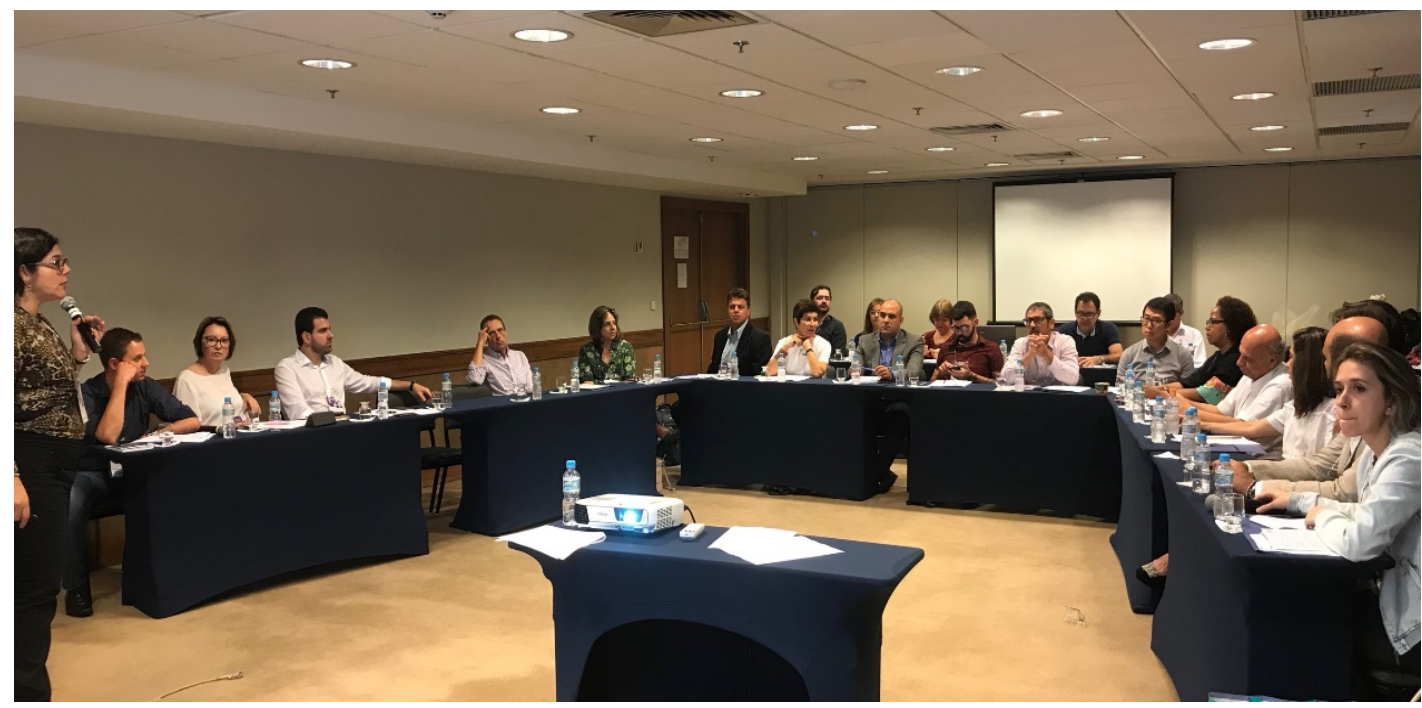

Figura 10: Imagem dos representantes da indústria reunidos no comitê para discutir a educação

\section{7}

A relação ensino e indústria: uma visão a partir das impressões durante a participação do Comitê Técnico Setorial

A fim de manter o enfoque pertinente ao recorte dado neste trabalho, escolhemos destacar os pontos que se relacionam com essa pesquisa, pois o registro do evento teve aproximadamente 20 horas de áudio, além das entrevistas e anotações feitas com cerca de 15 representantes da indústria de empresas como Renner, Salinas, Reserva, Osklen/Instituto-e, Malwee, Vicunha, dentre outras. Neste trabalho, não pretendemos nos ater exaustivamente aos conteúdos ligados as falas de cada membro das empresas, nem tampouco enfatizar a representatividade das empresas participantes em relação ao mercado de moda. O enfoque é destacar somente as falas que se relacionam com o objeto de pesquisa.

Ao final dos debates em torno de grandes mesas redondas com os participantes, um dos pontos que chamou a atenção foi com relação as diferenças no vocabulário utilizado no setor, de acordo com cada região representada ali por eles. Tais diferenças, reforçam a ideia de que em um país com a extensão geográfica do Brasil, é importante que haja um esforço por parte das instituições que regulam em cima das normas e padrões no sentido de buscar uma padronização da linguagem. Essas diferenças 
impactam no entendimento entre produtores, fornecedores, compradores, distribuidores, varejistas, atacadistas etc., em cadeia. Tal óbice também afeta o ensino, uma vez que o vocabulário utilizado para se referir ao setor nem sempre coincide com o que se apresenta no mercado de trabalho.

Para além do óbice dos regionalismos na comunicação, outra barreira se impõe nessa esteira: se desdobra para linguagem técnica. As falas dos representantes da indústria denunciaram um descompasso na construção de um currículo que ignora a necessidade de contemplar o ensino de termos técnicos da área no idioma inglês, considerado a língua universal. Muitos manuais, máquinas e equipamentos chegam com essa linguagem, sem contar as dificuldades para internacionalização de marcas (exportações) que dependem de uma comunicação assertiva.

Os entraves na comunicação do setor da moda, acarreta, além dos prejuízos mencionados, prejuízos na atividade do designer e do empreendedor. Um exemplo disso, é o discurso do designer e empresário de moda praia, Amir Slama ${ }^{94}$. Em entrevista concedida para a pesquisadora, no dia 06 de setembro de 2017, Amir narrou a sua dificuldade em traduzir fichas técnicas dos modelos dos biquínis criado no Brasil para que os chineses pudessem produzir em grande escala. A solução foi enviar o modelo de ficha técnica brasileira semiadaptado para na China. Lá eles readaptavam aos seus formatos técnicos. Tal processo, exigia que o modelo chinês ainda voltasse para o Brasil, para aprovação final do designer.

Outro ponto a ser destacado é com relação as capacidades comportamentais. Segundo os participantes, o ensino, em geral não contempla as chamadas soft skills. Tal aspecto coincide com a entrevista realizada no "chão de fábrica" da Salinas. O tema também foi evidenciado como um "grande problema", pois abrange todo o setor, nacionalmente. Segundo os participantes, a questão comportamental impacta no desempenho dos profissionais, nas relações de trabalho e consequentemente na produção.

\footnotetext{
${ }^{94} \mathrm{O}$ designer e empresário fundou a marca Rosa Chá que teve projeção internacional na moda praia. A marca foi vendida e Slama se desligou da sua gestão em 2010. Atualmente ele promove sua nova marca homônima de moda praia premium. Nota da pesquisadora conforme conversa com o empresário no lançamento de sua loja em Ipanema em 2018.
} 
Outro tema que teve grande destaque na visão dos representantes da indústria foi dobre a responsabilidade social e ambiental no setor. Discutiu-se acerca de termos como sustentabilidade e moda ecológica. Apesar da denuncia em relação a enorme banalização que tais termos recebem, com o apelo do "marketing verde" ou eco wash. Ocorre que o mercado se apropria de tais termos, seguindo a lógica de consumo.

Foi falado sobre "consciência planetária" e cosmologia como pautas urgentes, para se repensar os modos de produção. Tais temas abrangeriam todo o projeto de produto, desde o estágio de idealização, até o consumidor final, pensando no transporte, na distribuição e no descarte. O tema da sustentabilidade tem relação com o que cada vez mais os consumidores buscam, dentre as diversas qualidades que um produto deve contemplar. O discurso dos participantes, nesse sentido, se assemelhou ao dos alunos dos grupos focais, como sendo fundamental que se pense e implemente novas práticas sustentáveis, desde a etapa do ensino.

Foi dito que há um anseio geral em readaptar a produção e o consumo, contudo, poucas são as empresas que de fato colocam em prática o discurso eco wash, dentro da realidade dos seus processos de produção. No evento, apenas 2 das empresas participantes se manifestaram nesse sentido, apresentando projetos de domínio público. Segundo os participantes, existem muitos entraves para se conseguir readaptar a produção para um modelo mais sustentável. Uma das barreiras é a financeira, para o investimento em processos, tecnologias e fornecedores. Outra barreira, são as leis brasileiras que regulam e fiscalizam. Elas gerariam dificuldades com demasiadas exigências burocráticas de selos e certificações difíceis de serem obtidos.

Os segmentos de maior expressividade do setor de moda citados foram: a moda praia, a moda íntima e o jeans. Houve manifestações de descontentamento em relação aos poucos ou inexistentes investimentos para o setor e que correspondam ao tamanho da notoriedade desses mercados, segundo os participantes. A crítica não foi feita apensas no que se refere a investimento econômico para a indústria, mas de forma ampla, abarcando o ensino.

Segundo o representante da maior produtora de jeans do mundo, o Brasil não possui profissionais aptos a trabalhar em segmentos específicos, "devido a falta de atenção que o ensino dá na hora de montar os conteúdos formativos dos seus cursos". 
Tal problema não é resolvido com o que é oferecido no ensino. Os alunos e trabalhadores dos segmentos do jeans ou moda praia chegam despreparados para o mercado de trabalho, pois o ensino ocorre de forma fragmentada. Segundo os participantes, para suprir as demandas desses segmentos, os alunos deveriam aprender sobre processos químicos, beneficiamentos têxteis e demais temas ligados aos produtos de maior expressão nos mercados internos e externos, isso já dentro da grade curricular dos cursos de moda.

O espaço para a discussão sobre a educação no setor de moda com um grupo heterogêneo de profissionais da indústria, deveria ser ampliado, segundo os participantes. Deveria haver um acompanhamento contínuo das mudanças e dos resultados com grupos de entidades ligadas ao setor: "esse tipo de diálogo deveria ocorrer em toda a educação de moda".

A proposta de se discutir o ensino pensando em uma indústria 4.0 não foi totalmente aceita, uma vez que, muitos dos participantes questionaram o real impacto desse modelo industrial. Diante do que eles estão acostumados dentro da realidade industrial atual do Brasil, houve quem criticasse o descompasso entre o que se pretende adotar nos portfólios dos cursos, com o que os futuros profissionais vão encontrar nos postos de trabalho.

Entretanto, ao se explicar que o ensino tem um papel indutor na difusão de conhecimentos, e que para um posicionamento mais competitivo de mercado no mundo, o profissional precisa estar bem preparado para possíveis mudanças que podem acontecer do dia para noite, como as tecnologias disruptivas, o grupo concordou que “é preciso olhar para futuro, mas com os pés no chão".

Finalmente, para a surpresa da pesquisadora enquanto designer e coordenadora técnica do projeto: o grupo não demonstrou possuir um entendimento coerente sobre a atividade do designer. Ao serem questionados sobre como eles veem a atividade do designer de moda, alguns pediram explicações sobre quais seriam as funções do profissional dentro da cadeia de moda. Outros, disseram simplesmente que não enxergam importância na atividade desempenhada pelo designer. Houve também os que defenderam a atividade e deram alguns exemplos da sua relevância. 
Tal fato está associado em primeiro lugar ao problema da comunicação não padronizada na educação e na indústria, diagnosticado anteriormente. $O$ campo do design também possui algumas indefinições ou o excesso delas, que nem sempre concordam entre si. As muitas acepções ao uso da palavra "design" e a falta de iniciativas no investimento para o fortalecimento da importância da atividade, também se somam na resposta para tamanha desinformação.

Uma das estratégias adotadas pela pesquisadora para entender como o ensino poderia ser melhor articulado com a indústria, seria propor projetos pilotos/experimentais de integração entre os dois universos. Para tornar viável que tal ideia fosse realizável, dentro do tempo e escopo da pesquisa, a pesquisadora propôs a empresa do grupo de moda Reserva ${ }^{95}$ uma parceria para o desenvolvimento das etapas do projeto, que teve como escopo a busca por soluções para um problema real trazido pela empresa.

\footnotetext{
${ }^{95}$ Marca de moda carioca inicialmente direcionada ao público masculino dentro do mercado sportwear premium brasileiro. A marca surgiu em 2004 dentro de circuitos de eventos de moda do Rio de Janeiro e logo teve a entrada de um sócio famoso (Luciano Hulk). A pesquisadora acompanhou a evolução participando de diversos eventos como varejista na mesma época e publicando artigos sobre divesos assuntos ligados à marca em seu blog pessoal (janaramorenna.blogspot.com). Atualmente a Reserva é um grupo com outras marcas nos segmentos feminino, infantil e social.
} 


\title{
5
}

\section{PROJETOS EXPERIMENTAIS PARA INTEGRAÇÃO ENTRE ENSINO E INDÚSTRIA}

\author{
Conhecer e pensar não é chegar a uma verdade absolutamente certa, mas dialogar com a \\ incerteza 96
}

\section{1 Apresentação do capítulo}

Diante da dificuldade narrada pelos representantes da indústria, para conseguir alunos estagiários aptos para as funções abertas nas empresas, a pesquisadora propôs desenvolver uma proposta de conciliação entre os dois campos: do mundo do trabalho e do ensino. Conforme apresentado nos capítulos anteriores, a distância entre os dois universos foi verificada nas falas dos participantes ao longo dessa tese.

Foram feitos então, 2 projetos experimentais integradores entre o ensino e indústria. O primeiro experimento foi realizado no final de 2017 com alunos do SENAI CETIQT e a marca carioca de moda Reserva. Em um segundo momento, em 2018, foi realizado o experimento 2: partiu do desenvolvimento de um escopo de modelo de negócio de moda encomendado pela Escola de Samba Grande Rio. Tal projeto foi pensado com base na articulação com o ensino, em parceria com 2 faculdades de moda do Rio de Janeiro. Este capítulo é dedicado aos experimentos realizados para sugestão de projetos que visam a aproximação entre o ensino e a indústria na área da moda.

\footnotetext{
${ }^{96}$ Edgar Morin, (2001, p.59)
} 


\section{2 EXPERIMENTO 1: ALUNOS, PROFESSORES E A EMPRESA}

O problema colocado por uma representante da empresa do grupo Reserva estaria na dificuldade de encontrar estagiários. Os alunos dos cursos de moda, em geral, reclamam da falta de oportunidades de estágios na área. Segundo a representante da empresa, existe uma inadequação do ensino no sentido de pouco desenvolver algumas habilidades consideradas fundamentais no mundo do trabalho. Tal problema, estaria impactando nas atividades dos funcionários como um todo e, portanto, na produção, uma vez que erros técnicos ou a inadequação comportamental no trabalho em equipe, geraria resultados negativos para a empresa.

Ao analisar os requisitos colocados pela empresa, sobre o perfil desejável para a vaga de estágio, verificou-se que tal perfil estaria em descompasso com o que é oferecido no ensino de moda em geral. De um lado, a empresa deveria ter conhecimento sobre o que seria razoável exigir dos alunos, de acordo com cada curso e etapa de ensino para determinadas funções no estágio. De outro lado, a escola deveria melhor adaptar o ensino, a fim de promover a absorção dos alunos no mercado, uma vez que é o objetivo da escola formar profissionais bem preparados para atuarem na sociedade.

A pesquisadora idealizou este projeto após realização do comitê com representantes da indústria e concomitantemente a pesquisa para redesenho de currículo. Com isso, identificou que havia uma falha das instituições de ensino em geral, em preparar os alunos para esta etapa de transição: a saída do mundo acadêmico para a inserção no mercado de trabalho.

De acordo com a maioria dos participantes e entrevistados do capítulo 4, os alunos chegam pouco preparados tecnicamente e principalmente em relação a postura comportamental e em termos de "atitudes" (soft skills). O diferencial do projeto piloto foi dele ir se delimitando a partir da necessidade de implementar uma série de ações para que a escolha dos alunos fosse feita com base nos critérios e necessidades reais da empresa.

Diante do contexto, buscou-se pensar estratégias para entregar ao mercado/indústria um perfil que fosse aderente ao que a empresa buscava. Entendeuse que para tal era preciso ir além da dinâmica de grupo com os setores de RH (Relações 
Humanas). Seria necessário inovar unindo treinamentos intensivos, palestras e provas criativas.

Foi formado um grupo de trabalho interdisciplinar envolvendo professores e setores responsáveis por estágios da instituição para o desenvolvimento de um cronograma que contemplasse os prazos estipulados pela empresa, conciliasse com agendas dos envolvidos e dessem conta do conteúdo a ser apresentado aos alunos. O trabalho teve participação fundamental de diversos funcionários da empresa de vários setores incluindo áreas técnicas e do design.

O prazo estabelecido pela empresa foi de 1 mês para chegarem a escolha dos alunos finalistas para concorrerem a uma vaga de estágio. Com isso, o cronograma foi dividido em fases semanais que comportou as seguintes ações e atividades:

1. Visita técnica do grupo de trabalho na empresa;

2. Validação do cronograma com as etapas de trabalho e ações;

3. Divulgação, inscrição e primeira etapa de prova dos alunos;

4. $\quad$ Etapa de pontuação dos alunos;

5. Palestras sobre mercado de trabalho, comportamento e motivacional;

6. Visita do RH da empresa com dinâmica de grupo, apresentação e seleção dos alunos para a próxima fase;

7. Treinamento técnico com professores;

8. Prova técnica;

9. Banca de avaliação com equipe da empresa, na instituição, e escolha dos melhores alunos para entrevista individual com o grupo da empresa e da instituição (acompanhando);

10. Resultado dos 5 escolhidos para visita técnica na empresa;

11. Visita dos 5 escolhidos e prova surpresa;

12. Ampla divulgação dos resultados e análise do projeto para prospecção, ajustes e desdobramentos futuros.

As atividades divididas em 3 fases contemplaram capacidades técnicas e comportamentais. A banca avaliadora foi montada com professores e representantes da 
indústria da empresa em questão. $\mathrm{O}$ objetivo desse experimento foi de colocar em prática um plano de ação e, a partir das etapas que se seguiram analisar criticamente seus resultados para então propor que a experiência se torne um projeto transversal de interação entre áreas da escola com as empresas, como será colocado no final do capítulo, sobre os possíveis desdobramentos. Seguem os registros das etapas do projeto experimental:

\section{Release}

Estamos selecionando alunos engajados e com vontade de aprender para estágio em uma marca carioca, jovem, com mais de 1500 funcionários. A empresa cresceu muito nos seus 11 anos de existência. O grupo hoje tem 3 marcas, mais de 1400 pontos de venda entre lojas próprias e multimarcas. Participa dos principais eventos de moda, tem mais de 2 milhões de fãs no Facebook. Descolada, feita por jovens para jovens questionadores e cansados da mesmice. Marca preocupada com a qualidade de seus produtos e com o relacionamento com seus clientes.

\section{Pré-requisitos}

1. Inglês básico é fundamental!

2. Saber usar o pacote office (word, excel, corel) e Illustrator

3. Ser criativo, proativo, ter postura resiliente, organizado e detalhista.

4. Gostar de trabalhar em equipe, aceitando críticas e trazer ideias novas e colaborativas.

5. Ter compromisso com horários, cumprimento de prazos e metas.

6. Descrição da vaga 1: Modelagem

7. Descrição da vaga 2: Controle de qualidade

Funções: Saber construir uma peça em suas etapas e processos (maquinários, operações). Saber desenvolver uma ficha técnica completa, saber tirar boas medidas. Avaliar uma peça na mão em termos de qualidade e entender tipos de acabamentos.

O estagiário precisa conhecer a produção (não é para fazer ou consertar modelagem). Precisa entender por exemplo noções de problemas de modelagem, o que é uma cintura anatômica, corte de gancho, fechamento de gola, um acabamento de cós 
bem feito, ter "olho crítico" para processos, tipos de maquinários usados para cada modelo/etapa. Os estagiários não vão trabalhar com Audaces (os fornecedores que usam). $\mathrm{O}$ entendimento de modelagem é para entender os processos e usar como ferramenta para análises de qualidade (texto adaptado do que foi recebido pela empresa pela pesquisadora).

Carga de trabalho: 6 horas/dia

Funções: Estagiária Local: EP e Qualidade (produto)

Salário e benefícios: R\$ (não divulgado) + VT

\section{ETAPAS DE SELEÇÃO}

Etapa 1: Pré-seleção com mais de um professor de referência nas requeridas áreas, divulgar entre os alunos dentro da área e perfil desejado.

Etapa 2: Desenvolver desafio com professores envolvendo as demandas da empresa.

Etapa 3: Seleção dos alunos com participação da empresa e envio dos currículos com projeto desenvolvido.

\section{DESAFIO: MODELAGEM, QUALIDADE E ANÁLISE DO PRODUTO}

1. Prova prática de interpretação, análise e desenvolvimento de produto com a elaboração de uma ficha técnica, incluindo o desenho técnico, descrevendo detalhes e processos.

2. Fazer uma descrição do produto, detalhando comentários, verificando todos os aspectos solicitados pelos estilistas $\mathrm{x}$ peça piloto recebida do fornecedor.

3. Identificar todos os pontos para dar um visto de "ok" ou indicar o que precisa ser acertado para adequação ao solicitado.

4. Analisar produtos, tirar medidas e conferir com o solicitado pela empresa.

5. Analisar os beneficiamentos da peça piloto.

6. A marca enviará uma peça de sua coleção para essa análise, como referência. 
A fim de aproximar o leitor ao "espírito" deste piloto selecionamos algumas imagens do material de divulgação, fotos e textos utilizados para promover o projeto na ocasião em que ele foi divulgado.

\section{PEÇAS DE COMUNICAÇÃO}

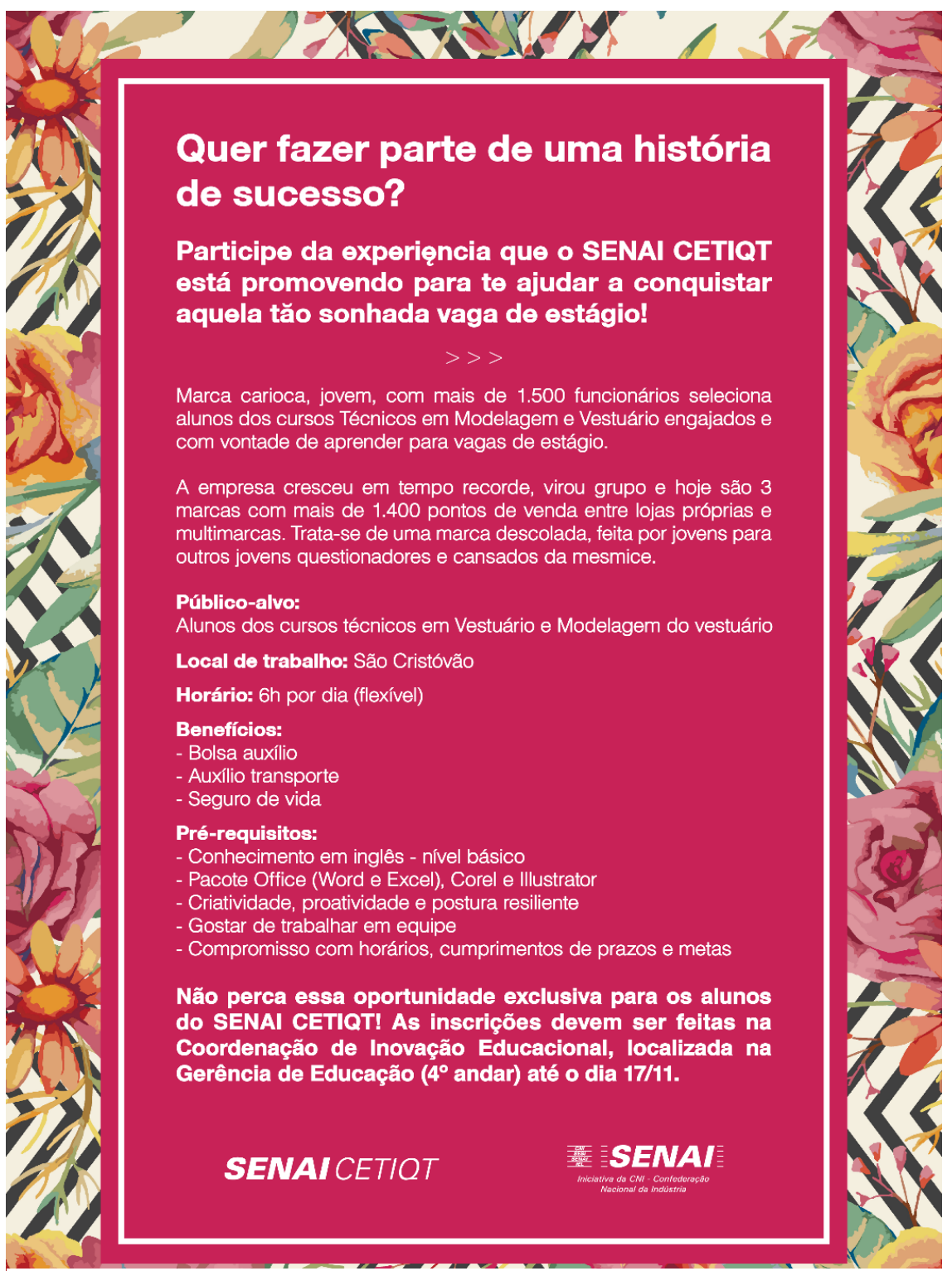

Figura 11: Imagem da peça de comunicação 


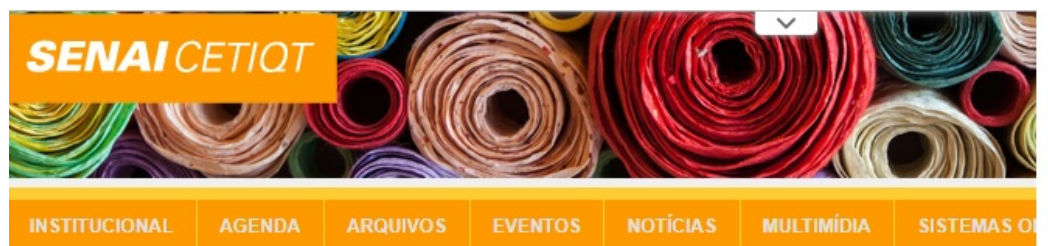

\section{Reserva busca talentos no SENAI CETIQT}

A empresa abriu vagas de estágio e buscou possíveis candidatos no SENAI CETIQT.

Os alunos inscritos participaram de uma agenda que começava com a entrega de um vídeo produzido por eles para uma primeira apresentação. Em um segundo momento, eles participaram de palestras sobre o mercado de trabalho com especialistas, além de uma dinâmica de grupo com o RH da marca Reserva.

Na segunda etapa do projeto, os alunos participaram de um treinamento com professores para a prova prática que acontecerá dia $1^{\circ}$ de dezembro com uma banca composta por profissionais da empresa. $\mathrm{Na}$ terceira etapa, os alunos selecionados irão visitar a fábrica e farão uma nova prova prática surpresa, encerrando um ciclo de imersão e preparo para processos de seleção!

O projeto

Essa parceria faz parte de um projeto idealizado pela colaboradora Janara Morenna na área de Projetos Estratégicos de Educação, integrando a Coordenação de Inovação Educacional. Ele busca integrar diversos setores da Instituição a fim de impulsionar a inserção dos alunos dos cursos técnicos. Com o objetivo de aproximar a educação com as demandas reais da indústria e entendendo a dificuldade em entregar um perfil de aluno que fosse aderente ao que a empresa busca, o projeto busca inovar, indo além da dinâmica de grupo com os setores de $\mathrm{RH}$ e o quadro de avisos com a vaga anunciada.

Confira as fotos da dinâmica de grupo:

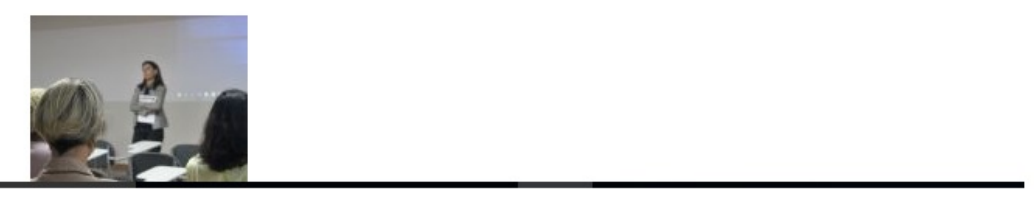

Figura 12: Imagem da peça de divulgação das etapas do projeto

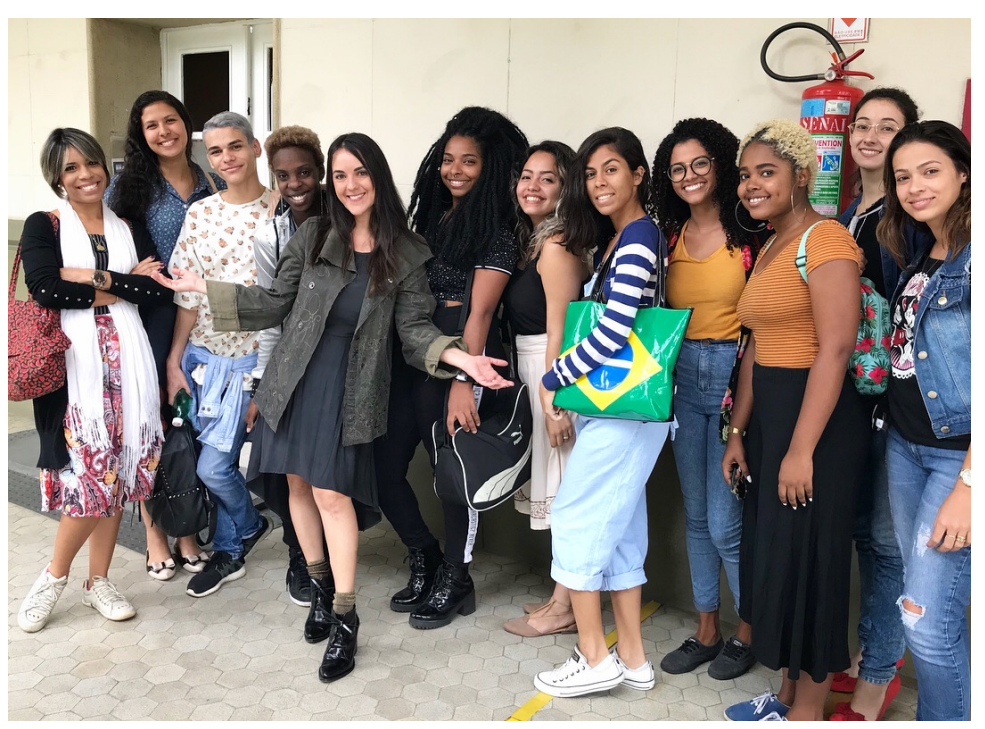

Figura 13: Acervo próprio da pesquisadora com alunos de moda 


\section{Memória do projeto experimental de engajamento de alunos SENAI CETIQT ensino - mercado de trabalho}
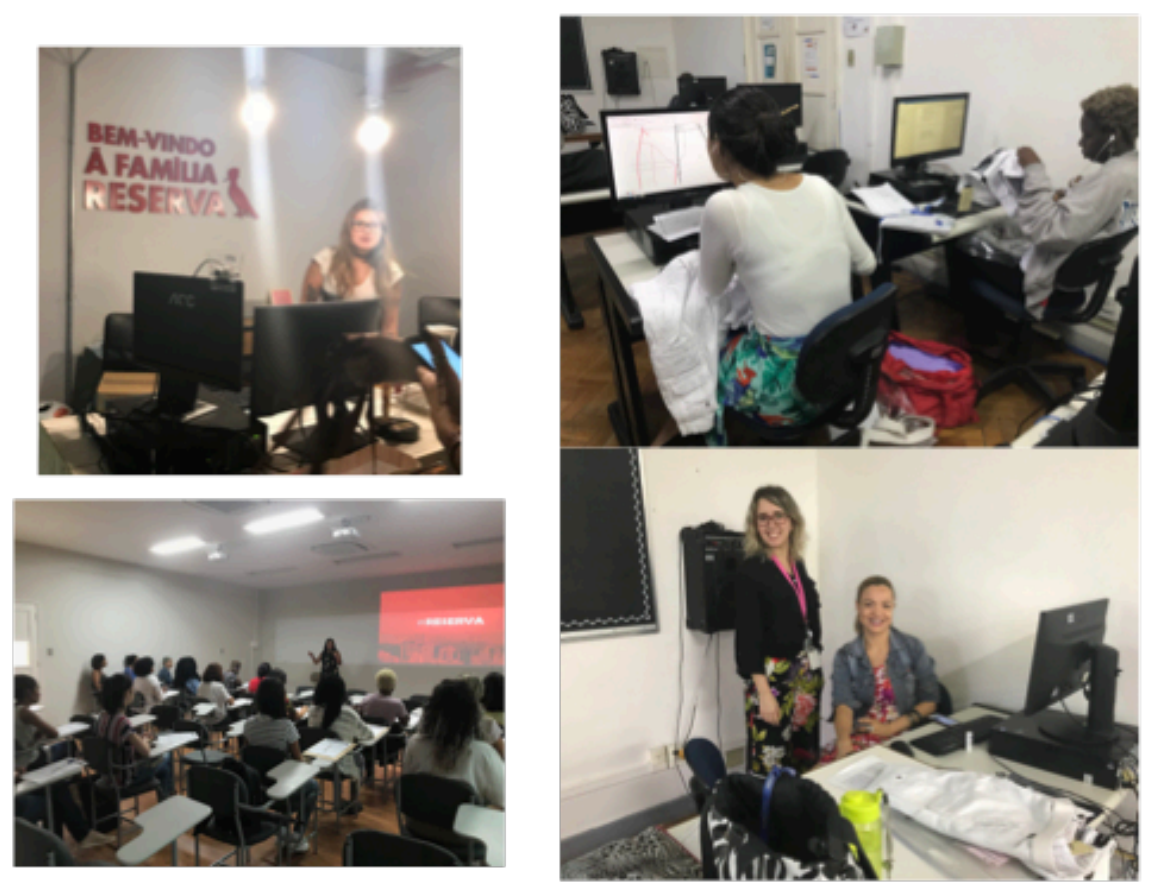

Figura 14: Imagens de diversas etapas do projeto na indústria e em sala de aula.

\section{ANÁLISE DOS RESULTADOS DO EXPERIMENTO 1}

Segundo Edgar Morin, "o caráter funcional do ensino leva a reduzir o professor 'ao funcionário", muitas vezes, o excesso de formalidades e burocracias pode engessar o profissional do ensino. Segundo o autor, o ensino não deve apenas se restringir a uma função, especialização ou profissão, o ensino deveria ser considerado uma tarefa de saúde pública, uma missão, “uma missão de transmissão. A transmissão exige, evidentemente, competência, mas também requer, além de uma técnica, uma arte". Para Morin (2001), há algo que não está explicado em nenhum manual, trata-se do que Platão já havia refletido, algo indispensável a todo ensino, relacionado ao eros, "que é, a um só tempo, desejo, prazer e amor; desejo e prazer de transmitir, amor pelo conhecimento e amor pelos alunos”. (2001, p.101). 
Os professores envolvidos no projeto atuaram diretamente no treinamento com os alunos. Segundo eles, todos estavam eufóricos. Os alunos que ganharam, se encontravam ansiosos para a próxima etapa final na empresa. Os que não foram selecionados estavam muito satisfeitos com os resultados obtidos e a maioria relatou não reconhecer em si mesmos a capacidade de fazer o trabalho solicitado. Todos ficaram com o sentimento de orgulho por terem passado por uma experiência profissional real enquanto ainda são alunos, segundo a professora Diva Costa.

Os pontos destacados pelos professores foram: ao se propor uma atividade que parte de uma demanda real de uma empresa, o ensino fica mais aderente, pois os alunos entendem o significado do desenvolvimento de competências e relevância das estratégias de aprendizagem aplicadas em aula.

Da parte da empresa, destaca-se a aprovação no que tange a qualidade dos trabalhos técnicos e das apresentações dos alunos. O ponto crítico foi a entrega dos currículos, que embora não tenha sido um pedido formal para a avaliação da empresa, pois nem todos os alunos que entregaram foram bem-sucedidos na redação, formato e conteúdo dos currículos. A sugestão da empresa foi de se incluir capacidades relacionadas à elaboração de "portfólio", para que o aluno desenvolva conhecimentos, habilidades e atitudes de transpor para o papel as atividades, capacidades e aptidões dele.

Por parte dos alunos, destaca-se a satisfação deles sobre a forma de aprendizagem "prática", que os aproximaram com a realidade no mundo do trabalho. Foi dito que a intensidade dos treinamentos fez com que em pouquíssimo tempo eles tivessem a sensação de terem absorvido muito mais conhecimentos que no ciclo de aulas, onde não há essa articulação com empresas. Para Morin (2001, p.76), a universidade e a sociedade devem se relacionar de forma complementar, o que produz um antagonismo entre duas missões da universidade se adaptar à sociedade e vice versa em um círculo que deve ser produtivo.

Os alunos também se motivaram com o fato de saberem o quão dificil é ter oportunidades de estágios e que esse preparo anterior os deixava mais seguros para outras oportunidades. Destacaram que a atividade em sala, em um projeto colocado por uma demanda real da empresa os fez entender melhor o desenvolvimento das 
competências previstas nos currículos adotados pela escola, que representam o perfil profissional que escolheram.

Os alunos puderam de fato, participar de uma atividade que faz a ponte entre a sala de aula e o "chão de fábrica", pois ambos os universos estavam presentes no projeto piloto. Reconheceram que precisam ter mais contato com a indústria, para o crescimento pessoal e profissional. Solicitaram que o projeto fosse mantido e ampliado.

O retorno das críticas e avaliação dos profissionais da empresa foi listado. A partir de então, todo esse contexto seria aproveitado para a criação de "situações de aprendizagem" que os professores costumam usar como estratégia de ensino.

Segundo representantes do Setor de estágios, que viabilizou o projeto dentro da área de estágio da instituição o resultado foi muito positivo, principalmente no que puderam observar nas reações dos alunos: "chegou a emocionar". Os pontos críticos ficaram no início do projeto, por ser inédito demorou a ficar organizado.

A sugestão para a gestão de projetos como esse seria de, a partir dessa experiência, construir um documento formal com o escopo do projeto para esclarecer dúvidas que poderiam surgir por parte da empresa. Além disso, também seria apresentado o escopo dos cursos para que a empresa saiba quais são as competências dos perfis profissionais, pois é de grande importância a mútua cooperação, abertura e flexibilidade para esse tipo de parceria. 


\section{3 PROJETO EXPERIMENTAL 2: MOMBA}

\section{Espaço híbrido: ensino, criação e produção}

Ao longo da construção do projeto ficou claro que os currículos dos cursos precisam contemplar o desenvolvimento das competências que os conecte com a realidade do trabalho. Muitas vezes, os alunos precisam de um treinamento, consultoria individualizada ou mentoria, para por exemplo, a elaboração de um portfólio, pois muitos alunos não souberam transpor as atividades informais ligadas à área de moda em seus currículos formais.

Para um melhor entendimento sobre a importância da participação dos alunos para adesão de propostas como a do experimento, foi necessário fazer uma sensibilização para a ativação do projeto. Os alunos deveriam enxergar valor na proposta independente do resultado final e dos seus objetivos profissionais, pois a atividade em si já é uma oportunidade de aprendizagem. Dessa forma, a fim de propor mais um experimento, dessa vez com alunos do curso de design de moda da PUC-Rio a pesquisadora buscou os setores de referência para o estágio na mesma instituição.

Diferente do que foi ouvido nas entrevistas com alguns alunos de design do DAD, existe sim um setor especialmente criado para orientação de alunos para a inserção no mercado. O setor CCESP de estágios oferece uma plataforma de cadastramento de currículo e um banco de divulgação de vagas além do espaço voltado para“orientação profissional, planejamento de carreiras e auxílio no processo seletivo". O setor também organiza capacitações em parceria com empresas e a Mostra PUC: um evento que reúne diversas empresas ocupando parte da universidade com stands de divulgação para promover o cadastramento de alunos interessados em vagas para estágio. Este seria o ponto alto em relação ao contato com empresas e mercado promovido pela universidade anualmente. 
Os pontos baixos na articulação entre universidade e mercado estariam na divulgação do próprio setor ${ }^{97}$. A baixa oferta de estágios para a área especifica do design também contribui para as dificuldades encontradas pelos alunos e a pouca comunicação entre os setores do DAD e do CCESP causa um desencontro de informações que se houvesse um esforço de comunicação poderia potencializar as parcerias e gerar mais oportunidades para os alunos.

Além dos serviços do CCESP há uma rede de suporte ao aluno integrada com outros setores da própria universidade, como o SPA (Serviço de Psicologia Aplicada), O RAE (Rede de Apoio ao Estudante), o PSICOM (Serviço Comunitário de orientação psicológica), o NOAP (Núcleo de Orientação e Atendimento Psicopedagógico) e o SOU-CTC (Serviço de Orientação ao Universitário). Há uma comunicação entre os setores de acordo com publicações no site da PUC-Rio, contudo, a maioria dos alunos desconhece tais setores, de acordo com as falas dos mesmos e com a experiência da pesquisadora enquanto aluna e representante discente dos alunos de Pós e do Colegiado do PPG Design.

Apesar de considerarmos importante replicar o experimento realizado no SENAI a fim de promover uma visão mais abrangente sobre essa articulação (ensino e indústria) agora na PUC Rio, não foi possível realizar tal experimento por diversos fatores. Dentre eles a própria dificuldade em encontrar empresas que se interessassem em fazer esse tipo de parceria que exige um envolvimento grande por parte dos profissionais que atuam dentro das áreas de recursos humanos das marcas de moda.

Inicialmente, iríamos fazer com a marca de moda praia Blue Man que estava interessada na ação. Em um segundo momento não conseguimos mais resposta dos funcionários da empresa. Buscamos outras alternativas com professores do Departamento e divulgamos a proposta do experimento diretamente para diversas marcas cariocas mas não obtemos retorno de nenhuma interessada após meses de tentativas.

A pesquisadora iniciou então um outro tipo de experimento envolvendo designers de moda em formação e recém-formados com a ONG Pimpolhos da Escola de Samba

\footnotetext{
${ }^{97}$ Vale ressaltar que as entrevistas feitas com alunos foram anteriores a uma campanha de divulgação do CCESP realizada nos espaços de maior circulação da PUC Rio com cartazes enormes associando o nome do setor a sua função principal - os estágios.
} 
Grande Rio (G.R.E.S.). O projeto nomeado "MOMBA" - moda com samba! foi sendo desenhado, de acordo com uma metodologia proposta pela pesquisadora a ser apresentado a seguir.

A proposta se conecta com as questões de pesquisa uma vez que se identificou inúmeras dificuldades encontradas pelos designers de moda para empreender no Brasil e ainda mais no Rio de Janeiro. Essas dificuldades ocorrem pela notória falta de incentivos dos governos em relação a burocracia e o alto custo para abertura de empresa e também pela enorme dificuldade em encontrar locais para produção em escala menor de produtos de moda na cidade. Dificuldade que persiste desde os tempos em que a própria pesquisadora atuava como designer de moda e varejista da sua marca.
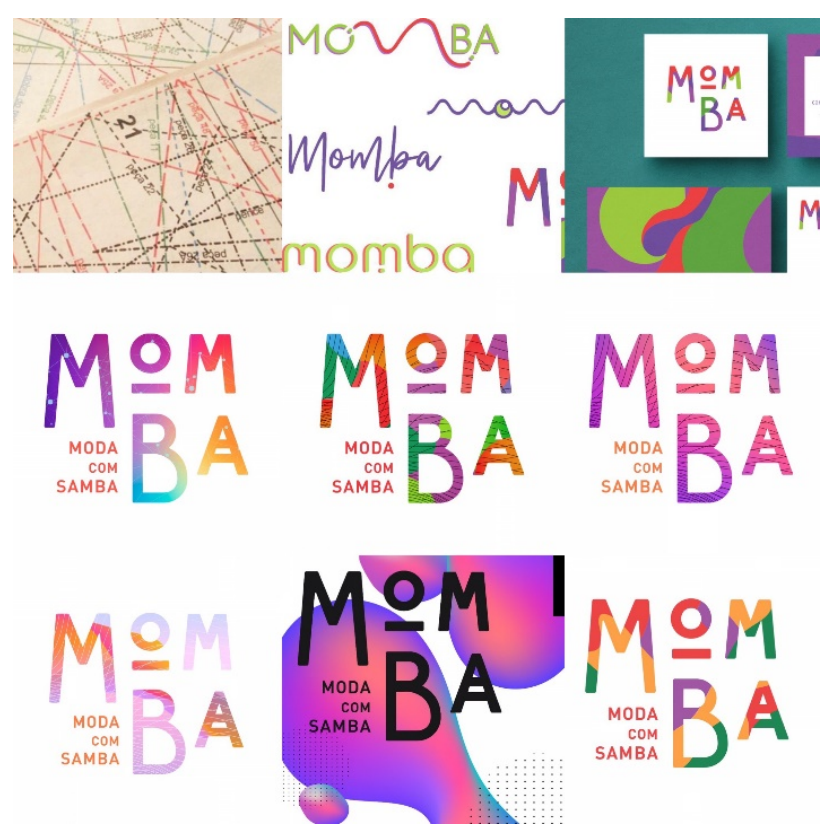

Figura 15: Imagem de parte do processo para criação da identidade visual fruto de um trabalho interdisciplinar

O cenário da moda para os designers empreendedores será melhor apresentado após a contextualização do escopo do MOMBA. O projeto surgiu a partir de um convite para a pesquisadora desenvolver uma consultoria para a criação de um modelo experimental de negócio com possibilidades que se articulam com a educação, uma vez 
que a Universidade Estácio de Sá é parceira da G.R.E.S e que o espaço possui uma estrutura industrial dentro dos moldes do chão de fábrica das confecções de moda.

A sazonalidade do carnaval e a alta despesa para manutenção da estrutura da G.R.E.S. impactam negativamente na sustentabilidade da escola. Os funcionários e terceirizados ficam sem trabalho por longos períodos entre um carnaval e outro. Levando em consideração as vantagens de um projeto de moda, de acordo com os objetivos da escola foi feito um diagnóstico das possíveis saídas para diferentes modelos de negócios para geração de oportunidades de trabalho, qualificação da mão de obra e sustentabilidade o ano todo.

O projeto foi desenvolvido a partir do mapemamento de oportunidades, nichos e segmentos, parceiros e prospecção de monetização a partir de um cronograma de ação e metas. Para o desenvolvimento do projeto que foi chamado de "modelo de negócio" quando apresentado para a escola de samba por correspondência com seus objetivos, aqui chamamos de "projeto experimental híbrido" por ser uma proposta totalmente inédita envolvendo escolas de samba, escolas de moda e novos designers/marcas.

Verificou-se que existe uma série de vantagens em criar um projeto como esse. Primeiro, por ser pioneiro dentro da tradição dos barracões, segundo pela reputação da própria escola em relação a inovação. O entendimento sobre o carnaval está cada vez mais associado ao da indústria criativa: dialoga com economia, cultura, moda, turismo, arte, memória etc. Há também uma percepção de valor dentro da dimensão social, uma vez que o carnaval movimenta a produção com mão de obra proveniente de centenas de comunidades com baixo índice de desenvolvimento humano (IDH) do Rio de Janeiro.

O barracão da G.R.E.S. se encontra em uma área que atualmente passou por grandes reformas urbanas e arquitetônicas. O espaço poderia ser gerar renda e investimentos para manter sua estrutura, além de maiores oportunidades de trabalho para seus afiliados se fosse melhor aproveitado na diversificação dos negócios.

Algumas técnicas de marketing e design thinking foram empregadas para gerar o quadro de pontos positivos e negativos, das ameaças e oportunidades de viabilidade, prospecção econômica e de sustentabilidade. Foi feito um levantamento do estado da arte de projetos que apresentavam alguma similaridade com o que estava sendo 
delineado e ao mesmo tempo, foram feitas pesquisas de campo com designers empreendedores de marcas novas.

A maioria das marcas autorais que surgem possuem um capital de investimento financeiro limitado. Portanto, optou-se por privilegiar esse tipo de marca e não as que surgem de grandes pools (grupos do setor) ou que recebem aportes grandes para investimento em estrutura e produção.

De acordo com o levantamento do inventário de capital material do barracão (para o projeto), ele contém máquinas de costura e corte de diversos tipos, além de outras tecnologias como o Audaces. O espaço pode ser facilmente adaptado a um modelo de facção para produção de produtos de moda. Dependendo do segmento de mercado a ser atingido poderia ser feito um investimento em modelos específicos de máquinas. O segmento da moda praia possui maquinários específicos e foi um dos sugeridos, devido a sazonalidade do mercado de moda praia ${ }^{98}$.

O Rio de Janeiro está carente em ofertas de facções/confecções principalmente para as pequenas empresas ou marcas novas. $\mathrm{O}$ acesso às facções na capital também não é fácil, normalmente ficam em áreas perigosas. Devido à essa escassez e as dificuldades para as marcas que não possuem um volume grande, a etapa da produção é um desafio.

Segundo relatório da Fundação Getúlio Vargas ${ }^{99}$ existem desvantagens para o empreendedor que precisa contratar os serviços de uma facção. Devido a baixa valorização da mão de obra o serviço fica comprometido. O tempo de entrega geralmente fica em descompasso com a rapidez do consumo (seguindo a lógica da efemeridade da moda) impactando nos negócios uma vez que o empreendedor precisa também girar seu investimento com rapidez para acompanhar o mercado:

\footnotetext{
${ }^{98}$ A produção no segmento é acelerada para as estações quentes do ano. Já a produção do carnaval leva cerca de 4 meses entre pré-produção, produção e pós-produção e se inicia quando a moda praia já está nas lojas.

99 Pesquisa "território da Moda” Fundação Getúlio Vargas. Fonte: http://www.rio.rj.gov.br/dlstatic/10112/1806097/DLFE-

230512.pdf/Territorios_da_ModaRelatorio_Quant.pdf, acesso em 17 de novembro de 2018.
} 
Outra questão seria a concorrência com grandes empresas que possuem preços mais competitivos, uma vez que fabricam em pólos têxteis mais baratos, no interior do Rio, em outros estados ou em países como China, Tailândia, India etc. Ressaltamos que tais locais inviabilizam o serviço para as marcas pequenas uma vez que exigem altíssimos níveis de produção em escala.

Tabela 20 - Principal problema na indústria da moda carioca para facções

\begin{tabular}{lrr}
\hline & $\mathbf{N}$ & $\mathbf{\%}$ \\
\hline As confecções pagam muito pouco por peça fechada & 1228 & 53,5 \\
Falta de qualificação da mão de obra & 686 & 29,9 \\
Excesso de impostos & 239 & 10,4 \\
Alto grau de informalidade do setor & 64 & 2,8 \\
Falta de orientação para gestão & 32 & 1,4 \\
Os prazos para entrega dos produtos são apertados & 32 & 1,4 \\
Outro & 16 & 0,7 \\
Total & 2296 & 100,0 \\
\hline
\end{tabular}

Fonte: CTS/FGV 2011

Quadro 4: tabela FGV (2011) sobre a indústria da moda carioca

Uma vez que o grau de conhecimento sobre o mercado pode variar para os que iniciam suas trajetórias de empreendedorismo e da notória carência na oferta de locais para produção em menor escala e com maior qualidade, seria interessante que o espaço de produção fosse híbrido. Pensando no público das novas marcas, que precisam de um atendimento mais customizado, o ideal seria concentrar em um mesmo ambiente profissionais de diversas etapas dos processos de produção: desde a criação, desenho técnico e modelagem, até o acompanhamento da produção dos produtos de moda.

A fragilidade de grande parte das escolas de moda em relação ao investimento em estrutura física para os alunos desenvolverem seus projetos também poderia ser aproveitada no escopo do MOMBA. Nesse sentido as parcerias com as próprias universidades poderiam servir para os alunos como uma ponte para o mercado. Além disso, universidades estrangeiras poderiam fazer intercâmbios para conhecer os processos de criação dentro de uma estrutura independente (das barreiras dos acordos de reciprocidade entre as instituições de ensino) e que promove além do carnaval, novas marcas cariocas de moda. 
Dentre as diversas possibilidades de criação de valor para o projeto, o importante é destacar que a partir do contato com as pequenas marcas, a pesquisadora pôde confirmar as dificuldades encontradas pelos designers de moda que buscam empreender. Tais dificuldades foram relatadas durante diversas fases da pesquisa, desde a visita às feirinhas de moda nos pilotis da PUC Rio, aos bazares de alunos do SENAI CETIQT. Também foram relatadas por ex alunos das mais variadas escolas durante a imersão no campo, na participação em eventos de moda e mercado como o Veste Rio e feiras de novos talentos.

A pesquisadora também entrou em contato com os organizadores dos eventos de moda que possuem em comum a posposta de reunir novos talentos. A fim coletar mais informações sobre as marcas novas, a pesquisadora entrou em contato com o produtor André Constemplate, criador do evento de moda "Carioquíssima", com a produtora Jê Muniz, criadora de "O mercado" e com produtora Tatiana Accioli, criadora do “Coletivo Carandaí 25". A partir do contato com os criadores/produtores dos eventos chegou-se aos designers indicados por eles para mais uma etapa de checagem de informações.

Todos os atores envolvidos nesta etapa corroboraram com as falas dos alunos de moda dos grupos focais e entrevistas citados nos capítulos anteriores. Optou-se por não fazer o registro transcrito/detalhado por entender que o assunto já foi trabalhado ao longo desse capítulo. Sendo assim, deixamos as conclusões finais para o capítulo 6, com recomendações para a área do design em suas extensões que abarcam a cultura, o mercado, o papel do designer e as ressalvas sobre as articulações entre ensino e indústria.

O processo de criação de identidade visual desenvolvido interdisciplinarmente com as expertises de três profissionais, a partir do briefing (instruções) passado pela pesquisadora e curadoria da responsável pelo projeto, Camila Coutinho ${ }^{100}$. A designer

\footnotetext{
${ }^{100}$ O convite para desenvolver o MOMBA surgiu por parte da Camila Coutinho. Mestre em Engenharia de Produção pela Universidade Federal Fluminense (UFF-Puro), pós-graduada em Gestão do Entretenimento pela Escola Superior de Propaganda e Marketing (ESPM-Rio) e em Gestão Empresarial pela Fundação Getúlio Vargas (FGV-Rio). Trabalha com gestão de Carnaval desde 2005 nas agremiações Pimpolhos da Grande Rio e Grande Rio e, desde então, vem pesquisando ferramentas de gerenciamento com objetivo de melhorar e sistematizar os processos produtivos e administrativos dentro da escola de samba. A designer Mariana Volker é Diretora de arte, formada em Comunicação
} 
Mariana Volker desenvolveu parte do processo buscando referências de letras que pudessem ser "mutantes", seguindo a lógica de um projeto experimental e híbrido entre criação/produção/negócios.

Para aproximação com o ensino, realizamos parcerias com as instituições SENAI CETIQT e Universidade Estácio de Sá. Com objetivo de buscar alunos ${ }^{101} \mathrm{com}$ capacidades técnicas e perfil polivalente, competências relacionadas às demandas do MOMBA, a parceria com o ensino foi fundamental para o desenvolvimento do projeto.

Para desenvolver o lado comercial com as empresas foi realizada uma apresentação do projeto no próprio barracão da Grande Rio, os convidados foram buscados de ônibus na Lagoa, Zona Sul do Rio de Janeiro. Dentro da Cidade do Samba, na região da Gamboa, foi feito um passeio pelos setores do barracão, até chegar nos espaços modulares, pensados para desenvolvimento e confecção.

O modelo de negócio foi apresentado detalhadamente em uma palestra contando os objetivos e o propósito do projeto. No final, propomos um momento lúdico nos ateliers para experimentação de fantasias e um lanche descontraído. Ali, foram cadastradas as primeiras marcas autorais cariocas que logo estariam desenvolvendo suas coleções no MOMBA.

Os estagiários foram alocados entre áreas de alta tecnologia, como para o manuseio do Audaces e da máquina de corte à laser e também para o atendimento com os clientes das marcas. Como são atividades diversas, o perfil desejado para o estágio foi de estudantes com maior adaptabilidade para interação tanto com máquinas, quanto com pessoas, coincidindo com as falas dos representantes da indústria. Para melhorar a qualidade dos serviços e cumprir a função do estágio, oferecemos treinamentos in company, (no barracão) para os estagiários, com consultores do Audaces, além do aperfeiçoamento com o pessoal experiente da Escola de Samba.

Social/Publicidade e Propaganda pela PUC-Rio em 2011. É Pós-Graduada em Comunicação Integrada pela ESPM, possui cursos de extensão em Marketing Digital (Infnet) e Branding (Laje/Ana Couto) e mais de 10 anos de experiência no mercado. http://mia.art.br/

${ }^{101}$ Os estagiários até o mês de abril eram 1 fixo do MOMBA e outros 4 da Escola de Samba Grande Rio, com atuação direta e indireta no projeto. Os demais prestadores de serviço vinham da comunidade ligada à Escola e na época do carnaval profissionais externos. 
A primeira experiência comercial do MOMBA foi para uma produção de 200 peças com promessa de mais 300: desenvolvemos a modelagem, corte, costura e entregamos dentro dos saquinhos etiquetado. Por um erro interno no dimensionamento das peças, o cálculo para os prazos de entrega e número de costureiras foi subestimado. No final, fizemos metade das peças e não tivemos retorno no investimento feito. Essa experiência nos fez refletir sobre o contexto dos modelos de negócio da indústria e das facções.

Com isso, o MOMBA foi, aos poucos sendo organicamente reposicionado, visando um mercado que valoriza a mão de obra. Para o futuro, espera-se uma articulação maior com as instituições de ensino e com setores ligados à educação do governo para promover no local oficinas e capacitações, e ao mesmo tempo, atender demandas de marcas pequenas, autorais, com práticas éticas de produção e baixa escala/slow fashion. 


\title{
6. CONSIDERAÇÕES FINAIS E PROPOSTA DE DESDOBRAMENTOS FUTUROS
}

\author{
É preciso substituir um pensamento disjuntivo e redutor por um pensamento do complexo, no \\ sentido originário do termo complexus: o que é tecido junto \\ Edgar Morin
}

\section{1 Apresentação do capítulo}

Esse trabalho privilegiou a escuta de diversos atores, do ensino à indústria. $\mathrm{O}$ levantamento histórico trouxe ao leitor um panorama sobre a origem do segmento do mercado da moda praia. Chegando ao final, buscou-se também ouvir uma voz que contemplasse uma visão global das articulações entre ensino e indústria, trazendo novas perspectivas conectas ao consumo que atravessa o discurso de todas as áreas contempladas nessa tese.

Este capítulo tem como objetivo trazer para o leitor um balanço do trabalho realizado e a apresentação das sugestões de desdobramentos futuros. Para tal, o capítulo foi estruturalmente dividido em 3 sessões que tratam de 1) de uma visão panorâmica sobre a moda praia no contexto da educação e da indústria na voz de comunicadores; 2) trata do papel do designer como conciliador entre a moda praia em suas extensões mercado, indústria, cultura e ensino e 3) a conclusão do trabalho com desdobramentos futuros e as sugestões obtidas a partir dos projetos experimentais.

\section{2 \\ Uma visão panorâmica sobre as relações ensino e indústria}

O papel de um profissional da área de comunicação pode em alguma instância ser comparado ao do designer. Não no sentido do exercício da atividade em si, e sim quando pensamos no designer-conciliador entre a cultura e mercado, com o público consumidor para o qual ele projeta e a indústria que responde ao mercado, que por vez, está dentro da cultura. Nessa interconexão há um diálogo entre as áreas desde os tempos 
em que o designer compunha a famosa dupla com o redator e, por isso, buscou-se alguém que representasse o topo da cadeia do jornalismo de moda no Brasil.

No cenário do jornalismo de moda do Brasil, a jornalista Daniela Falcão ${ }^{102}$ possui grande destaque. Além de ocupar por décadas posições importantes nas revistas relevantes de moda, Daniela vai além da redação. Durante o período dessa tese, um fato que chamou a atenção da pesquisadora foi a enorme quantidade de eventos promovidos por instituições de ensino e do setor de moda que tinham a jornalista como convidada principal.

A revista Vogue Brasil é tratada como uma marca, segundo Daniela. Ela precisa estar em todas as plataformas da internet, precisa participar de eventos e precisa ainda promover eventos. Os alunos de moda são os leitores da revista e "a mulher Vogue" é a frequentadora de eventos como o Veste Rio, que tem a missão de promover as marcas brasileiras. Durante a investida no campo, a pesquisadora ouviu Daniela falar com o público em várias ocasiões e foi por isso que o contato para uma entrevista foi possível. Após diversas tentativas, veio o convite da entrevista ser concedida em São Paulo, dentro do escritório da Globo Condé Nast.

Realizada em 6 de setembro de 2018, as perguntas foram previamente enviadas por e-mail. O roteiro de perguntas não foi seguido de forma estruturada (à risca), pois via de regra um assunto emendava com outra resposta. Pela longa extensão do áudio gravado na entrevista, optou-se por selecionar os trechos mais relevantes para o leitor:

Sobre a relação ensino e indústria na moda praia brasileira, Daniela logo associou ao ensino técnico, segundo ela o Brasil tem a tradição de formar os profissionais pela indústria para a indústria, contudo, quando se trata do ensino superior deixamos a desejar:

A gente não tem uma tradição de educação para moda para a indústria da moda como um todo, na parte mais acadêmica e de terceiro grau é pior ainda. Quando a gente fala

\footnotetext{
${ }^{102}$ A jornalista iniciou sua carreira ne década de 1990, ates de trabalhar com moda passou por diversas áreas como cultura, política, comportamento e cidade em vários jornais brasileiros. Desde lá passou pela direção de redação de revistas como TPM, TRIP e Vogue Brasil. Desde 2016 assumiu o cargo de diretora das Edições Globo Condé Nast que detém quatro importantes publicações de moda e design: Vogue, Glamour, GQ Brasil (masculina) além da Vogue Casa (design e arquitetura). Sua trajetória é também tema para um documentário. Em 2018 Daniela foi eleita pelo 6 ano consecutivo uma das pessoas mais influentes da moda no mundo, pela Business of Fashion. Fonte: Site da Vogue Brasil, acesso em 17 de março de 2019.
} 
em indústria a gente esta falando tanto em comércio quanto criação, quanto à indústria em si, certo? Você não está querendo saber só com a costureira, você está preocupada como é que é a educação da costureira, modelista, estilista, um diretor de criação.... Então eu acho que o trabalho clássico que o SENAC sempre fez de você formar essa mão de obra que é mais uma mão de obra industrial mesmo, essa formação é bastante boa porque sempre funcionou no Brasil. Você tem a tradição da indústria formar as pessoas que ela precisa muito através do SENAI e SENAC, então essas instituições que a gente chama de pára-estatais que são o sistema $\mathrm{S}$, eles prestam um excelente trabalho, do mesmo jeito que eles formam quase todos os garçons para um restaurante, para hotelaria e tal, na indústria da moda é bastante bom para essas funções de entrada porque é o target deles.

Para Daniela, o Brasil não possui nenhuma instituição de ensino de moda de referência se compararmos com alguns outros países que possuem opções diversificadas de interface com outras áreas. A fala da jornalista coloca a questão da desvalorização do ensino de moda denunciada no primeiro capítulo sobre a produção acadêmica de moda no Brasil (Cláudia Bonadio) e a falta de disciplinas dentro da administração e economia (Enrico Cietta):

(...) ao contrário de outros países que você fecha o olho e sabe que tem uma grande escola de moda, mas sobretudo nos países onde a moda tem uma indústria viva, então a França você tem a ESMOD que é excelente, em Londres você tem excelentes escolas, tem (na Itália) o Instituto Europeu de Design, então é um absurdo por exemplo, a FGV não ter um curso de marketing de moda. Até a gente, eu digo, como Globo Condé Nast estamos fazendo parcerias com a ESPM sobretudo, para fazer marketing digital com a Glamour e de marketing de luxo com a Vogue, mas são cursos da Pós, não são cursos regulares, são aqueles que eles chamam de MBA, mas na verdade são cursos de extensão (...). Por exemplo, a Bocconi que é a "FGV da Itália", várias pessoas daqui que foram estudar lá depois conseguiram empregos na Ferragamo, então, a melhor escola de administração tem também administração em moda, a moda já faz parte do currículo. Nova York tem 3 ou 4 grandes, você tem o FIT, você tem a Parson's, você tem a (inaudível). Você tem três grandes, aqui você tinha a Santa Marcellina que era uma faculdade que formou boa parte dos estilistas dos anos 1990. Foi aquele boom de indústria nacional, eles foram formados pela Santa Marcellina. Tem a FAAP que é uma coisa menos focada no estilista, mas a pessoa que quer trabalhar em revista ou marketing de moda, não é um curso que está entre os destaques da FAAP, que inclusive tem um monte de cursos que é meio improvisado. Eu acho que a gente perdeu a chance...

Segundo a jornalista, se formar em uma excelente faculdade de moda não traz a sensação de sucesso profissional se comparado com outras áreas na interface com o mercado de trabalho. Apesar da popularidade da moda no Brasil, os mais privilegiados buscam a formação fora do país e nem sempre quem trabalha com moda teve formação na área: 
O que eu mais recebo é aluno que fez uma outra faculdade e quer trabalhar com moda, adolescente, ou pós adolescente, falam assim: 'onde é que eu vou estudar lá fora?' Porque não existe realmente aqui, um lugar que você fala 'putz, (SIC) se eu vier para São Paulo ou para o Rio e eu me formar nesse lugar, eu vou conseguir um bom emprego porque eu vou ter estudado em uma excelente faculdade' - não existe isso, então assim, infelizmente a moda ganhou muita popularidade e as pessoas acham legal trabalhar com moda, teve todo o boom do São Paulo Fashion Week, mas isso não quer dizer que a gente tenha a educação para aproveitar esse hype, a moda não caminhou junto com pessoas bem formadas, articuladas e tal.

Fazendo um paralelo com as falas dos alunos, Daniela mencionou a dificuldade de encontrar cursos de áreas específicas da moda, como a estamparia, e ao mesmo tempo, apesar de haver muita oferta de cursos técnicos, há uma desvalorização desses cursos e dos respectivos profissionais capacitados neles. Tal cenário, além de ser um exemplo do descompasso entre as demandas do mercado de trabalho e a falta de atenção dada pela área de educação, acabaria por também gerar problemas para quem depende desses profissionais. Conforme apontado no capítulo 5 sobre as dificuldades para produzir em fábricas e facções.

(...) tem muita coisa específica que não existe. Mesmo a estamparia tem um pouquinho, mas se você for conversar com quem contrata, com os grupos, todo mundo reclama. A gente fez uma vez um armazém que foi a maior dificuldade. A gente queria mostrar justamente os bastidores dessas pessoas incríveis, mas o Reinaldo Lourenço disse 'não, não vou mostrar minha modelista porque uma vez eu já fui roubado'. Acontece de ter uma briga ali, pois é um profissional super disputado (o modelista) e o Reynaldo tem uma visão super crítica. Ele fala que essa é uma profissão que foi perdendo a coisa do trabalho manual, ela foi perdendo o glamour e o interesse e daqui a pouco nós não vamos ter mais modelista aqui. Então mesmo que você tenha o sistema $\mathrm{S}$ treinando essas pessoas, se você não valorizar, se você não tiver um esforço, e como você valoriza no fundo no fundo? É quando você tem um curso de graduação, se na graduação não tem isso, se as pessoas não estão falando, porque que a adolescente que entra no sistema $S$ vai escolher uma carreira que ninguém esta falando?

Outro problema seria a falta de referências teóricas e formais também sentida pela pesquisadora. Tal falta de referências gerou a motivação para essa pesquisa:

A gente tem todo esse problema, a gente não tem uma bibliografia de moda, lá fora tem uma série de livros, aqui mesmo traduzindo tem muito pouco. Claro que somos um país novo, desde o início do século XX, 1910, a França, a Inglaterra e os Estados Unidos produzem moda consistentemente. A moda no Brasil, o Preta à Porter começou nos anos 1960. Então claro que a gente é bem mais jovem do que eles, mas de qualquer maneira já estava na hora, se você for em uma livraria e olhar por exemplo tudo que tem de inovação ou de startup e vai ver os livros de moda, é obvio que falta, não é uma questão de idade só, nunca houve essa produção intelectual ou acadêmica de um jeito que acompanhasse. Tirando os TCCs muito pouco 'pensar acadêmico' é feito sobre moda. 
Pesquisadora: então você acha que existe um gap entre o ensino e o mercado de uma forma geral?

Acho, acho que a gente não conseguiu levar isso para a academia, entendeu? Nem com os cursos, nem com produção intelectual, com nada. Continua sendo uma profissão marginal apesar do hype porque não houve esse acompanhamento da educação.

Outro aspecto levantado que faz um paralelo com as falas dos alunos e também dos designers empreendedores é sobre a estrutura dos espaços de moda nas universidades e em geral:

Eu acho que faltam lugares que você possa discutir a moda, eu fui visitar a casa FIRJAN, eles têm uma oficina de costura como eu não vi em nenhum lugar (...) isso tinha que ter em todo o estado, ali no Rio foi uma exceção porque a FIRJAN está fazendo andar. Tem uns laboratórios incríveis, então acho que isso faz falta e você conta nos dedos as faculdades, esqueci da Belas Artes que até tem uns laboratórios muito bons, mas por exemplo, a FAAP não tem, então como você vai fazer uma profissão que é essencialmente prática - claro que tem que ter um pouco de teoria mas sobretudo mão na massa também, como é que você vai fazer isso sem ter estrutura? É a mesma coisa de você formar jornalista sem ter um estúdio de TV ou sem computador para conseguir fazer, então é uma aparelhagem que é importante.

Sobre o segmento da moda praia brasileira Daniela falou longamente com olhar de quem além de promover marcas nacionais tem contato estreito com os designers empreendedores ao longo da sua carreira. Perguntou-se qual a visão dela sobre a importância da moda praia para o mercado brasileiro:

Eu acho que tem duas coisas muito importantes, eu acho que a gente exporta muito bem - então na exportação moda praia não é só porque a gente tem prestigio mas a gente tem expedisse, qualidade e um preço competitivo, então esbarra também numa falta de incentivo maior do governo em relação à exportação de indústria têxtil, aí não é só a questão de moda mas dentro desse cenário de dificuldade, disparado toda grande marca de moda praia se você perguntar eles tem alguma exportação, diferentemente de um Reynaldo Lourenço, de um Alexandre Herchcovitch, uma empresa mediana no Brasil de moda praia ela já exporta, é um mercado.

Pesquisadora: às vezes nem vende para o mercado interno, só exporta, né?

É, a (marca) VIX começou assim, você começa lá fora né, é o nome do Brasil e a expertise que a gente tem do uso - porque as pessoas usam o biquíni efetivamente, então é um território que esta pronto lá fora, enquanto o nosso produto mais sofisticado, porque a gente não tem essa cultura dos ateliers, que isso é uma moda muito recente, a gente não tem nem a expertise então o nosso produto é de qualidade inferior ao dos países 
principais da moda, aí junto o preço, por todas as dificuldades de produção, o 'custo Brasil' e tal, aí isso termina inviabilizando qualquer tentativa mais forte de exportação num mercado cada vez mais competitivo.

Alexandre Herchcovitch já teve loja lá fora; a Osklen se mantém, mas ela puxa para o Beachwear um pouco lá fora; é uma coisa de lifestyle mas é um lifestyle baseado na praia, aí eu acho que internamente além de ser disparado um pólo de emprego importante, o Rio/Friburgo é super importante na moda praia, dentro desses núcleos que a FIRJAN tem - os pólos que eles chamam onde se produz - eu tô falando do cara que tem marca pequenininha, você tem lingerie, moda praia, moda noite (camisola e pijama).

Quando perguntada sobre a internacionalização das marcas em relação aos players de fora e como a moda praia pode estar perdendo espaço no mercado pelos obstáculos entre ensino e indústria, Daniela destaca também a falta de incentivo do governo:

Nesse caso não acho que seja tanto a relação ensino e indústria, acho que é mais a falta de uma politica de incentivo, a maior feira de Beachwear do mundo acontece em julho em Miami, os brasileiros dominavam, agora tem muita concorrência sim, mas não é um problema de falta de mão de obra é um problema de falta de incentivo e a crise que o país esta passando. Então acho que sim, a gente esta perdendo espaço para outros países ainda que de novo, continua sendo o melhor lugar para você estar se você quer exportar, mas a gente tinha uma posição muito melhor porque a crise não tinha deixado tanta gente tão mal. Agora se você for visitar multimarcas lá fora, o produto brasileiro continua tendo destaque: a Lenny esta em países importantes, a Salinas exporta para caramba, ainda é, e ninguém vai tirar o Brasil... Nova Zelândia e Austrália tem a cultura do surf mas quando as pessoas pensam sobretudo em feminino ma moda, onde se faz um biquíni? No Brasil, tanto que a depilação faz "brazillian bikini”, isso as pessoas não vão tirar da gente. Mas que já fomos supremos e agora tem concorrência é verdade.

Janara - Eu pesquisei muito a questão do corpo no mestrado, entrevistei o prof. Dr. Ivo Pitanguy na época, sobre como o corpo foi mudando e o design acompanhando, agora fala-se muito de movimentos de resistência em relação à normalização de beleza... percebi recentemente muitos desfiles que a própria Vogue publicou com modelos com diferentes corpos, falando de uma suposta "democratização dos corpos", como você tem percebido essa relação dos corpos com o design na moda praia?

Eu acho que a moda praia sempre foi mais democrática nesse sentido de corpos do que outros segmentos que tinham tamanhos rígidos porque se você for a praia, e eu já ouvi de várias pessoas de fora que é impressionante como a brasileira mostra o corpo dela independentemente da forma - pois, em geral, elas não são magras, eu não estou falando da modelo, mas a população da praia. Tem um monte de gente com celulite, mais gordinha e que usa biquíni na boa, então a gente fala muito da ditadura da moda mas é uma coisa de passarela (...). Então a gente continua lançando modismos que enaltecem um corpo de sonho, mas ok, também porque você tem o lado do consumo de massa e tem uma moda praia que tem isso.

Sobre moda e educação e a revista Vogue /Glamour 
Quando a gente vê que existe essa lacuna (na educação/moda) e as pessoas têm uma curiosidade muito grande de saber como é o dia a dia daqui a gente hoje em dia tem parceria com a ESPM, tem cursos 2 vezes ao ano. A gente faz também com uma instituição que chama fashion meeting, que são cursos de finais de semana e muito mais focados em jornalismo de moda na Vogue, então tem jornalismo de moda e produção de moda, o produtor de moda acompanha um dia de um shooting que a gente faz, então os alunos de fashion shooting... Virou para mim uma fonte de renda que não é muito dinheiro mas é constante, a gente tem renovado e é importante do meu lado não só porque é uma fonte de renda mas também porque você faz os títulos (Vogue, Glamour) ficarem mais próximos da nova geração, porque são alunos que estão se formando. Então tem essa carência e obviamente Vogue e Glamour são nomes que atraem e é importante para gente estar na cabeça de quem esta se formando.

Apesar de não existir uma inciativa para promover o segmento da moda praia em específico, embora seja relevante para a indústria nacional, Daniela enxerga uma atenção especial ao tema:

(...) eu acho que existe um carinho, a gente acolhe, não é uma inciativa orquestrada, não existe um núcleo de moda praia da Apex ${ }^{103}$ por exemplo. Tem o pólo, mas o pólo é porque ele é fabricante mas não existe uma associação brasileiras de estilistas de moda praia, então não é um movimento organizado... Mas por exemplo, o último livro de moda produzido aqui no Brasil que deu o que falar foi da Lilian (Pacce) e sobre biquíni. E exposição? Sobre biquíni (também da Lilian Pacce)... É um tema que ela sabia que existe esse carinho. Eu vejo surgir muita marca de moda praia nova, no Veste Rio agora tinha umas 3 ou 4 ... eles (Veste Rio) estão promovendo porque você tem um histórico muito bom, vende fácil, você pode exportar. Se alguém me dissesse "quero abrir um negócio" eu ia dizer: 'moda praia/fitness' porque você vai ter mais chance de fazer sucesso lá fora. A gente tem a fama de ser bom nisso, então acho que ajuda muito, não tem ajuda mas sozinho eu acho que é o único mercado brasileiro que conseguiu se manter, a indústria calçadista também é muito forte, eles tem um poder econômico muito grande, eles têm a revista (uma edição especial da própria Vogue, nota da pesquisadora), eles são organizados, se tivesse na moda praia a organização que o setor calçadista tem a moda praia estaria bombando, teria uma revista; a Francal, e a Couro Moda (grandes feiras de moda atacadista), ou seja, você tem duas feiras organizadas pelas indústria que são focadas em calçado.

Janara: não existe nenhuma feira de moda praia no Brasil?

Não, não tem de moda praia, você tem esses núcleos, como a gente falou, mas não existe uma feira e mesmo a venda de lycra não tem um grande momento que todo mundo esteja olhando o que vai ser feito (lançamentos). Então acho que um bom exemplo, se o setor de moda praia tivesse a organização de indústria de sapatos porque não é o governo que fez isso ali, se você tivesse isso na moda praia imagina o boom que não seria?

${ }^{103}$ A Agência Brasileira de Promoção de Exportações e Investimentos visa promover os produtos brasileiros no exterior. Fonte: http://www.apexbrasil.com.br/Noticia/MARCAS-BRASILEIRAS-DEMODA-PRAIA-ATERRISSAM-EM-MIAMI, acesso em 20 de março de 2019. 
Janara: em que você acha que estamos inovando?

Uma coisa que eu acho impressionante que veio para ficar e que não tem como mudar é hoje em dia você quer um sutiã sem bojo. Você tem que brigar porque para toda essa mulherada que não necessariamente colocou o silicone o sutiã é enorme, tudo bem que você pode tirar o bojo se você quiser, ele te dá opção, mas antigamente não existia isso. O boom do tomara que caia é obvio que tem a ver com essa mulher que tem uma prótese porque você não precisa da sustentação.

Diante do exposto pela jornalista de moda, chegamos a algumas conclusões: a educação voltada para a parte técnica no Brasil é mais ampla e atende melhor que a educação superior, ainda que as funções técnicas sejam menos valorizadas (em seus aspectos econômicos pelos baixos salários e também simbólicos: “a falta de glamour”). Isso se dá pela tradição do país em capacitar sua mão de obra a partir das demandas da indústria local. Nesse sentido formar comitês com representantes da indústria para a discussão de currículos faz todo sentido, mas só poderia ser viabilizado se coordenado com os profissionais da área de educação com inserção profissional na área do design (no caso do setor da moda).

A baixa valorização da moda na educação do Brasil é generalizada, se reflete na falta de escolas de referência com relevância internacional e na falta de disciplinas que façam interface com outras áreas, como a administração, economia, ergonomia e o marketing. Embora existam muitos cursos pulverizados em marketing não encontramos graduações com ênfase na área, nem nas escolas tradicionais de negócios.

A fragilidade do ensino de moda no Brasil tem seus reflexos no mercado de trabalho, existe um disparate de nivelamento de conhecimentos entre os funcionários de marcas de moda. As mesmas funções podem ser ofertadas para pessoas com ou sem formação na área. Não estamos desprezando o conhecimento empírico, a comparação se dá por entendermos que esse desnivelamento compromete o desempenho e a comunicação de uma empresa em vários níveis. Nesse sentido, o designer que chega com uma bagagem maior poderia atuar no papel de indutor de conhecimentos dentro da empresa, muitas vezes, administrada por empresários que não são da área. 


\section{3 \\ O DESIGNER COMO CONCILIADOR ENTRE CULTURA E MERCADO PARA UM DESIGN COMO DIFERENCIAL COMPETITIVO}

Ao longo dessa tese, ouvimos as vozes de representantes de diversas áreas. Chegamos ao final retomando os aspectos importantes para um balanço geral do que foi levantado, de acordo com as técnicas de pesquisa. A visão de que o ensino de moda praia se encontra fragmentado e que há uma distância na relação com a indústria foi se confirmando nas falas de todos os participantes ao longo do trabalho.

Foi dito que de um lado, temos um ensino técnico sujeito a críticas, mas que atende o mercado de trabalho, e que isso seria o resultado da tradição do país em capacitar seus profissionais para a indústria. De outro, temos um ensino superior de moda deixando a desejar em vários aspectos: na oferta, na sua estrutura física, na correlação ("aderência") com a realidade do mundo do trabalho, no pouco investimento em inovação e incentivo a pesquisa.

Sobre a explicação para que a moda praia seja um caso de sucesso da indústria nacional, mesmo diante de um contexto cheio de entraves e falta de incentivos para o segmento, a resposta para tal êxito estaria no design como diferencial competitivo, segundo os atores participantes. Neste quesito, os atributos mais citados foram em termos da qualidade na modelagem, na estamparia, na padronagem, além dos atributos formais dos materiais e do conforto dos produtos. Para além dos atributos que geram desejo de consumo e da qualidade que confere status à moda praia brasileira, a cultura de praia e do corpo seria o pano de fundo para a formação de um mercado forte nesse segmento, de acordo com as falas dos atores.

Em relação ao mercado global, embora a moda praia brasileira esteja na posição de liderança em termos de exportações, de acordo com as pesquisas de mercado apresentadas no início dessa tese, ocorre também uma acelerada mudança no cenário global. O fortalecimento do segmento de moda praia em outros países como Austrália, China e Estados Unidos vem trazendo fortes marcas estrangeiras que disputam a fatia de mercado internacional e podem penetrar no mercado brasileiro, como é o caso da 
marca americana Victoria's Secret, ${ }^{104}$ com grande reputação no segmento de moda íntima, e que atualmente investe cada vez mais em moda praia.

Há também o fenômeno das empresas de exportação com plataformas de $e$ commerce pela internet e oferta de marcas de moda praia vendidas no atacado e varejo. Tais produtos, estão cada vez mais parecidos com os desenvolvidos no Brasil, seja no quesito estilo, seja na qualidade, ${ }^{105}$ ou até nos nomes: brazillian bikini.

Segundo entrevistados, não identificamos uma preocupação com relação a perda do mercado interno. Segundo eles, por se tratar de um segmento com produtos que contém fortes referências relevantes em termos de design na relação com o consumidor brasileiro. Identificamos nas falas que apesar dessa sensação de segurança, no que se refere ao mercado externo há um certo "tom conformista".

Apesar dos esforços da APEX em promover a indústria nacional em eventos como o Miami Swim Week, realizado em Miami ${ }^{106}$, há indícios da diminuição gradativa da participação das marcas brasileiras na semana de moda praia americana, conforme apontado pela Alessandra Marins e Daniela Falcão. ${ }^{107} \mathrm{Na}$ visão da pesquisadora, o fato de não haver um evento específico e relevante no Brasil para a promoção da moda praia nacional é uma esquizofrenia, um desperdício em se tratando do potencial desse mercado.

Dentro dos atributos mencionados ao longo da pesquisa, destacamos também a atenção dada à modelagem e vestibilidade dos produtos de moda praia. Partindo da

104 De acordo com matéria da Revista Veja de 21 de maio de 2015, o maior sucesso de vendas da marca não era mais lingerie e sim moda praia. De acordo com a revista, o produto havia subido $10 \%$ nas vendas enquanto as vendas totais da empresa subiram só 5\%. Tal sucesso fez a marca mudar seu famoso desfile show, passou a incluir biquínis. Acesso em 14 de março de 2019. Fonte: https://veja.abril.com.br/economia/saiba-qual-e-o-maior-sucesso-de-vendas-da-victorias-secretacredite-nao-e-lingerie/

${ }^{105}$ De acordo com análise imagética feita ao longo do trabalho, por via do acompanhamento dos aplicativos e páginas na internet de empresas como Alibabab Group e E-bay, a pesquisadora pôde notar o aumento de ofertas de biquínis e maiôs inspirados na moda praia nacional. Grande parte exibia o nome "brazillian bikini" ou "brazillian style" para fazer referência ao design brasileiro.

106 O "Miami Swim Week" é o maior evento de moda praia no mundo. Desde 1982 ele acontece no Miami's Swimwear Convention e conta com marcas do mundo todo. Fonte: SwimShow (https://www.swimshow.com/) Acesso em 19 de março de 2019.

${ }^{107}$ De acordo com Daniela: "a maior feira de beachwear do mundo acontece em julho em Miami, os brasileiros dominavam, agora tem muita concorrência sim - mas não é um problema de falta de mão de obra é um problema de falta de incentivo e a crise que o país esta passando, então acho que sim, a gente esta perdendo espaço para outros países". 
noção de uma hipervalorização do corpo feminino da mulher brasileira, podemos aferir que o cuidado com as formas que compõem uma estrutura tridimensional, que é a roupa em seus aspectos formais (desenho, modelagem, corte, encaixes, costura), é proporcionalmente relativo aos "cuidados de si" de quem veste essa roupa. A modelagem deve ser perfeitamente desenhada seguindo a ordem do que se pretende destacar no corpo. A textura dos tecidos elásticos, Lycras e outros precisam ter a gramatura certa em harmonia com os suportes e o formato/shape que se pretende dar.

Todo o conjunto de técnicas e expertise em torno do fazer a moda praia resulta em um valor intangível da uma dimensão simbólica que contém a força da carga cultural e ao mesmo tempo, de um valor tangível ou "agregado" 108 . No caso da moda praia, a etiqueta made in Brazil $^{109}$ já inflaciona o valor do produto, não somente pelo esforço com as altas taxas para exportação, mas pela sua reputação nos mercados estrangeiros (OLIVEIRA, 2017, p.17). Tal fato, também pode ser facilmente comprovado quando pegamos o exemplo das marcas de biquíni que se posicionam no mercado de luxo. Quando vendidas com outras marcas premium, são geralmente mais caras que as concorrentes estrangeiras, de acordo com os entrevistados.

O setor de moda ou do vestuário, de acordo com o termo utilizado pela indústria, está dentro de categorizações dentro de uma lógica organizacional. A moda, além de fazer parte da "indústria da transformação", está junto com o design dentro da chamada Indústria Criativa. ${ }^{110}$ Sobre essa setorização que engloba atividades afins, o Rio de Janeiro lidera em termos de valorização da mão de obra, ultrapassando São Paulo nos

\footnotetext{
${ }^{108}$ No caso citado a expressão usada serve para indicar que tal marca/produto tem uma série de atributos que geram um valor de venda vantajoso.

109 De acordo com matéria da Folha: https://www1.folha.uol.com.br/ilustrada/2018/12/grifesbrasileiras-de-moda-praia-invadem-miami-e-batem-de-frente-com-versoes-genericas-brazilianstyle.shtml, acesso em 20 de março de 2019.

${ }^{110}$ No Brasil a FIRJAN faz um mapeamento a cada 2 anos desde 2008 de acompanhamento da indústria criativa. Tal pesquisa contempla o potencial dessa indústria, as tendências de mercado, a representatividade e evolução com base em dados do ministério do trabalho, dos profissionais que atuam na área e do valor da produção gerado dentro por ela. Dados extraídos do site da FIRJAN e do documento de Estudos e Pesquisa publicado em fevereiro de 2019 "Mapeamento da Indústria Criativa no Brasil", acesso em 14 de março, fonte: https://www.firjan.com.br/EconomiaCriativa/downloads/MapeamentoIndustriaCriativa.pdf. Sobre a indústria criativa e a moda usamos além do relatório foi usado como referência o livro "A economia da Moda” (CIETTA, 2017, p.65-100).
} 
salários $^{111}$, apesar da capital paulista concentrar número muito maior de ofertas de vagas dentro das ocupações da indústria criativa. Tal informação faz sentido quando pensamos no Rio de Janeiro como lançador nacional de tendências de moda.

Apesar da indústria criativa ser representativa no Rio de Janeiro, quando comparamos os dados dos salários dos profissionais que atuam na moda, a desvalorização da mão de obra chama atenção. Em relação a média salarial mensal do trabalhador brasileiro de $\mathrm{R} \$ 2.777$ reais (FIRJAN, 2017), a média salarial feita pelos profissionais criativos, usualmente mais qualificados foi 2.45 vezes superior, atingindo o valor de R\$ 6.801 reais. Contudo, a média de quem trabalha com moda é de apenas R\$ 2.074 reais, muito abaixo da média dos colegas da categoria Criativa e atrás inclusive da média geral de salário no Brasil.

Esse diagnóstico nos faz refletir sobre as falas dos entrevistados. Segundo Daniela Falcão, muitos profissionais que trabalham com moda vêm de outras áreas ou estudaram fora do Brasil, frequentemente os que ocupam posições mais privilegiadas no mercado de trabalho. No nível mais técnico há escassez de profissionais bem formados para certas áreas como modelagem. A falta de valorização da profissão resulta na baixa oferta de mão de obra na área.

As dificuldades encontradas no setor de moda do Brasil contribuem para a expansão das importações de países como a China. Ainda que na moda praia haja uma resistência, uma vez que os chineses não possuem marcas competitivas como as brasileiras, contudo, em busca do barateamento dos custos de produção, alguns empresários brasileiros já estão optando por fabricar seus biquínis na Ásia, como é o caso do entrevistado Amir Slama. Esse dilema entre valorizar a mão de obra no Brasil ou concorrer com os mercados voltados para grandes escalas acaba por gerar uma série

\footnotetext{
${ }^{111}$ Em São Paulo a oferta na Indústria Criativa é de 328,7 mil vínculos enquanto no Rio de Janeiro é de 88,9 mil. Os dois estados juntos formam $50 \%$ dos empregos criativos. Santa Catarina e Rio grande do Sul aparece em seguida. Moda e Design aparecem dentro da categoria "consumo" e tem os piores salários dentre as 16 áreas e 4 categorias: Consumo (Publicidade e marketing, arquitetura, design, moda), Cultura (expressões culturais, patrimônio e artes, música, artes cênicas), Mídias (editorial, audiovisual), Tecnologia (P\&D, TIC, biotecnologia). A média do salário do design (gráfico, multimídia e móveis) é de R\$ 3.276 reais e de moda R\$2.074 reais. Dados do IBGE desde 2015 até 2017. Acesso em 14 de março, fonte: https://www.firjan.com.br/EconomiaCriativa/downloads/MapeamentoIndustriaCriativa.pdf
} 
de questões como o trabalho análogo a escravidão ou a pejotização ${ }^{112}$ dos profissionais do setor.

Para o efetivo crescimento da economia ${ }^{113}$, estratégias para impulsionar os setores industriais são fundamentais em um contexto de produção em escala internacional. Com a fragmentação da produção, principalmente direcionada aos países asiáticos, a principal estratégia para a competitividade nas cadeias de valor demanda alto grau de especialização e valor agregado com o uso de novas tecnologias disruptivas e ubíquas ${ }^{114}$ (SILVEIRA, 2017).

De acordo com o Instituto Brasileiro de Geografia e Estatística (IBGE, 2017), e a Secretaria de Comércio exterior, a maioria dos estados que apresenta elevada potência em termos de competitividade são os que operam nos setores mais intensivos em recursos naturais e mão de obra. Ao mesmo tempo, verifica-se uma perda de competitividade das exportações que operam nos setores intensivos em tecnologia.

A economia brasileira necessita de estratégias que impulsionem o aumento da participação dos setores mais intensivos em tecnologias nas exportações com incentivos aos processos de inovação para atender à crescente demanda do mercado doméstico. Nesse contexto, o design tem papel fundamental, ele se insere como elo que integra todo o contexto do consumo. Portanto, deve ser colocado na agenda estratégica da economia do país, sobretudo, se pensado dentro da indústria criativa, cujo PIB

\footnotetext{
112 A pejotização ocorre como estratégia das empresas para flexibilização das relações de trabalho. Visam diminuir os custos com encargos trabalhistas substituindo a mão de obra "pessoa física" por profissionais autônomos na figura da pessoa jurídica (PJ). A pejotização é uma tendência segundo relatório da FIRJAN sobre a indústria criativa. Ela é uma prática mais comum nesse meio também por conta da natureza dos projetos que nem sempre possuem fluxo contínuo, podem ser serviços contratados sob demanda.

${ }^{113}$ A economia brasileira teve uma grande retração, perdendo participação no PIB na indústria da transformação ao qual a moda está inserida nos últimos anos. Em 2012 chegou a representar 13,3\%, esse percentual é semelhante ao do ano de 1955 (antes do plano de metas de Juscelino Kubitschek, no primeiro ciclo significativo de industrialização). Esse cenário, divulgado no Diagnóstico do Design brasileiro (2014, vários autores), serve para reflexão sobre o atual cenário e a necessidade de fomentar a indústria elevando sua taxa de investimento. Fonte: http://www.mdic.gov.br/arquivos/dwnl_1435234546.pdf acesso em 19 de março de 2019.

${ }^{114}$ De acordo com a publicação do SENAI "a quarta revolução industrial do setor têxtil e de confecção" (2017) as tecnologias ubíquas compõem redes de produção modulares orientada pela indústria 4.0, são elas: automação e robótica, tecnologias da informação e de comunicação, sensores e atuadores, modelagem e simulação computação em nuvem, internet móvel, tecnologias sustentáveis, biotecnologia, materiais, Big Data.
} 
mundial é ser mensurado principalmente pela geração de patentes e propriedade intelectual.

Enquanto o cenário apresentado até aqui nos faz refletir sobre o segredo do sucesso por traz de uma moda que se fez representativa apesar todos os obstáculos apontados, temos cada vez mais o designer no centro, como conciliador entre cultura e mercado para um design como diferencial competitivo. Sendo o consumo cultural e a cultura plural, o designer articula cultura local, de praia, do corpo e o todo o repertório do imaginário com atributos de qualidade, conforto, estilo etc. para gerar valor percebido e validado dentro de uma dimensão carismática e simbólica das marcas e signos da lógica da moda.

Antigamente tal validação passava muito pelos pares em um processo de produção de notoriedade de nomes da moda e das marcas. Atualmente, a figura do designer de moda "estrela" se desloca. Fica restrita ao âmbito dos mercados de luxo e da alta costura. As marcas que antes eram alavancadas pela fama dos seus criadores ${ }^{115}$, agora são cada vez mais avaliadas pelos "ativos consumidores-expectadores" (LIPOVESTKY, 2016) conectados em redes virtuais e plataformas digitalizadas de uma "sociedade de consumidores", cujo cerne é o modus operandi da liquidez e do descarte que fluem em uma órbita de algoritmos.

A mudança de poder, agora nas mãos do consumidor que sente uma certa autonomia ao crer que está mais conectado com as marcas que o afetam, faz com que todo o mercado repense suas práticas para evitar cair no julgamento crítico que possa diminuir seus valores de mercado. Por exemplo, podemos citar no universo do luxo a frequente crítica por grupos de ativistas sobre o uso de peles de animais para confecção de acessórios. Outro exemplo, a instantaneidade do retorno de opinião sobre os desfiles divulgados em tempo real nas redes sociais. Tal retorno pode resultar no sucesso ou fracasso de uma temporada para a marca.

\footnotetext{
115 Os designers de moda já ocuparam um posto de maior prestígio, era comum o mercado disputar nomes relevantes por esses trazerem retorno de mídia e aumentar o consumo de produtos "assinados". Cada vez mais o designer perde o protagonismo para as marcas que investem na construção de uma identidade forte e na veiculação dessa identidade nas mídias. A exceção são os nomes internacionais da alta costura do consumo de luxo. Nota da pesquisadora.
} 
Também nesse rol, os escândalos envolvendo preconceito e racismo por parte dos representantes das marcas e empresas de moda podem acabar com a reputação das mesmas e impactar as vendas de um dia para o outro. ${ }^{116}$ A rapidez que a realidade das redes digitais trouxe para o consumo também facilita o acesso a um mundo de marcas menores ou pouco conhecidas fora do seu país de origem. Tal fato pode ser comprovado na pesquisa feita durante 40 meses entre 2015 e 2019 (fevereiro) usando uma conta criada exclusivamente para acompanhar marcas de moda praia.

Conforme dito no subcapítulo 2, o Instagram torna possível indexar uma quantidade imensurável de marcas do mundo. A partir de dados algoritmos, novos perfis semelhantes ao que foi buscado com atualizações constantes são sugeridos. Foram detectadas 800 contas associando mulheres modelos de moda praia e marcas do segmento. Desses perfis, foi feita a filtragem das contas de marcas e comércio eletrônico de moda praia. Em uma etapa posterior, foi feita a busca sobre o país de origem de cada marca. Os resultados seguem na imagem 17: "Gráfico das marcas de moda praia".

A quantidade de marcas diagnosticadas como sendo brasileiras correspondia à exatamente a soma das marcas de origem americana e australiana. China aparece inexpressiva. Convém lembrar que o gráfico não se refere ao país de fabricação, e sim de sua comercialização. Em 2018, a APEX divulgou um estudo sobre a moda praia australiana $^{117}$ apontando que os australianos produziam boa parte da produção dos artigos de moda praia nos países asiáticos.

\footnotetext{
${ }^{116}$ Como foi o caso da marca italiana Dolce \& Gabbana em campanha na China, por falta de pesquisa sobre aspectos culturais locais acabou por gerar uma onda de manifestações e teve seu desfile cancelado, modelos descredenciadas e o fechamento de pontos de venda - além do boicote em massa ao consumo da marca. Fonte: Dolce \& Gabbana versus China: o erro que abalou o império de luxo. Revista Veja, 23 de novembro de 2018. No Brasil, tivemos recentemente matéria na revista Veja sobre a moda praia feita por Adriana Degreas vinculada a uma declaração polêmica sobre ela "costurar para mulheres chiques e com bossa, não para as farofeiras que andam de chinelo e estendem canga na praia". O fato repercutiu instantaneamente e gerou revolta na internet por parte de ativistas que questionavam o preconceito na fala. Fonte: https://vejario.abril.com.br/blog/beira-mar/a-estilista-de-moda-que-virou-queridinha-dasfamosas-neste-verao/ acesso em 19 de março de 2019.

${ }^{117}$ Fonte: http://www.apexbrasil.com.br/blog/post/becreative-olha-que-coisa-mais-linda-mais-cheia-degraca, acesso em março de 2019.
} 


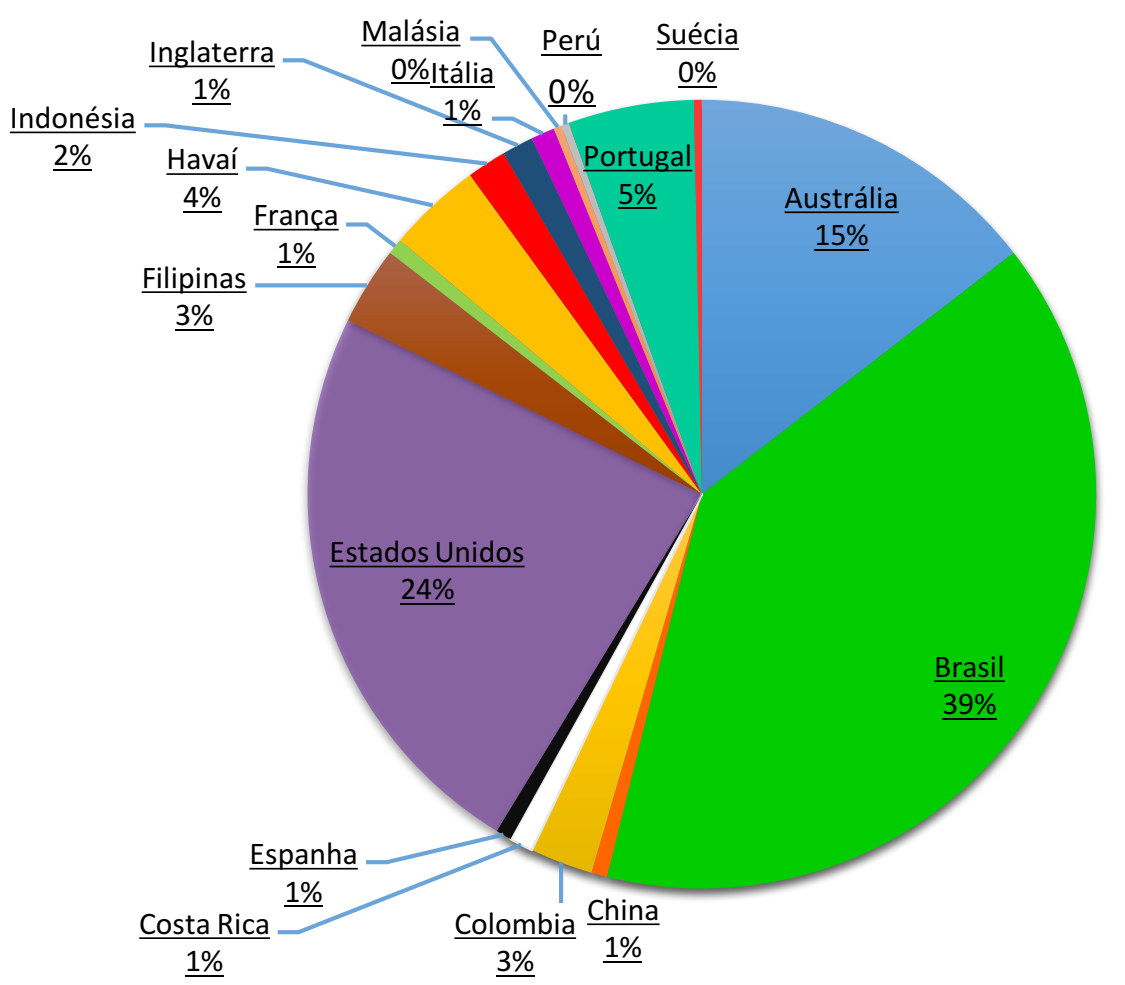

Figura 16: Gráfico das marcas de moda praia - encontradas e sugeridas pelo Instagram durante um período de 40 meses de uso da conta @doc.bikini criada em 2015.

\section{4 SUGESTÕES FUTURAS}

Algumas estratégias de boas práticas poderiam ser adotadas pelo Governo e pelas associações industriais brasileiras. A pesquisa, no âmbito científico é de suma importância quando conecta o levantamento do referencial teórico e conceitual, articulando com as situações apresentadas na pesquisa de campo. Foi verificado que as teses, dissertações e demais publicações acadêmicas raramente apareciam nas citações dos materiais produzidos pelos setores de fomento à indústria, comércio e afins.

A pesquisa de moda também deve ser vista do ponto de vista da complexidade, fazendo pontes com outras fontes, como consultorias e pesquisas de mercado, utilizando dados estratégicos para trabalhos acadêmicos. A articulação entre o ensino e a indústria deveria partir de um diálogo maior com academia, para fortalecer as 
estratégias inovadoras em torno dos produtos nacionais de maior destaque, como no caso aqui apresentado.

Partindo de uma visão de que as marcas de moda praia podem ser mais valorizadas por serem brasileiras, as estratégias de fortalecimento do capital simbólico utilizadas para potencializar o desejo de consumo, para além das qualidades formais do produto, aumentam seu valor percebido e reforçam o imaginário da cultura carioca em suas extensões ligadas ao DNA da moda praia carioca.

A sugestão para reforçar as narrativas em torno do DNA da moda praia carioca estariam no fortalecimento do incentivo ao desenvolvimento de projetos para promoção do segmento. Tais projetos poderiam vir de diversas esferas como: exposições, apresentações, filmes, documentários, projetos culturais envolvendo ambientes interativos, novas tecnologias, pesquisa e inovação ${ }^{118}$. Além dessas iniciativas, as publicações sérias, ou seja, as pesquisas que seguem o rigor do método científico, se mais bem aproveitadas pelo setor da moda, poderiam ser muito favoráveis no desenvolvimento do mercado, servindo de referencias para os que buscam empreender e projetar (o designer).

Um ponto importante a destacar, dentro da lógica de um consumo espetacularizado por meio das mídias sociais, é a importância de uma leitura crítica das tendências de comportamento social das novas gerações. A moda está, cada vez mais conectada a uma ideia de "propósito", para além do consumo frívolo. Surge, cada vez mais, uma moda com bandeira partidária, posicionamento ideológico e em manifesto.

$\mathrm{Na}$ esteira das reinvindicações políticas, sociais, ecológicas e humanistas, o deslocamento da construção da narrativa antes baseada em uma persona e seu "self life style" fura o hedonismo próprio da moda, para uma versão reinventada e mais plural.

\footnotetext{
${ }^{118}$ Há um documentário alemão sobre a moda praia, realizado com a participação um "bikinólogo" francês, Judson Rosebush. Enquanto os brasileiros, considerados experts na moda praia ainda não produziram algo relevante para multimídia, os alemães falam com o olhar estrangeiro da nossa cultura de praia. Apesar de ser um assunto que no Rio de Janeiro concentra profissionais aptos a colaborar com suas expertises referentes ao design de biquíni, à remodelagem corporal e aos usos (e desusos) do biquíni, a única proposta no âmbito da cultura até 2019 foi a exposição "Yes, nós temos biquíni” da Lilian Pacce no Centro Cultural banco do Brasil em maio de 2017. O documentário, foi exibido no Brasil no canal fechado GNT no dia 03 de fevereiro de 2014.
} 
Se os esforços para promoção da moda praia brasileira deslocasse dos modelos estereotipados de um corpo feminino sexualizado e objetivado, para o lugar da liberdade e da irreverência, estaríamos mais perto do que foi a moda praia no passado, símbolo de resistência e empoderamento na luta das mulheres pelo direito de dominar seus corpos.

O discurso do "corpo positivo" (body positive), que questiona os padrões de beleza historicamente publicitado pelos veículos de comunicação em massa, ajuda a desconstruir a imagem sexista em torno da mulher brasileira, especialmente a carioca. Muito aquém ainda dos estereótipos em torno dessa imagem, por muito tempo promovida internacionalmente pelo Brasil em suas propagandas para atrair turistas estrangeiros. A ressignificação de uma moda praia sexista seria um grande favor as mulheres brasileiras, uma vez que em alguns países é comum o preconceito com o brazillian bikini ${ }^{119}$.

A promoção do segmento pela via do fortalecimento de uma imagem mais atualizada com o momento que o mundo vive, além de aproximar ensino e indústria e valorizar o segmento, também pode ser mais facilmente replicada fora do país. Isso inclui repensar as formas de produção e descarte. As pesquisas de novos materiais, a partir de bactérias, tecidos biodegradáveis, tintas não tóxicas e reciclados vem ganhando espaço, embora muito lentamente no Brasil.

$\mathrm{Na}$ indústria têxtil, são poucas as opções para fabricação com materiais mais sustentáveis. No varejo, é quase inexistente o número de marcas que optam por esses modelos. Outro problema, é a apropriação de termos como "sustentabilidade" ${ }^{120}$ de

\footnotetext{
${ }^{119}$ Um exemplo são as atletas que disputam campeonatos de surf como a brasileira radicada no Havaí Tatiana Wenton-Webb que relata ser alvo de críticas de "ódio" nas redes sociais por preferir o modelo brasileiro de biquíni. No lugar de avaliarem sua capacidade competitiva acabam objetivando a atleta que se sente alvo de preconceito. Fonte Jornal extra 08 de maio de 2016.

${ }^{120}$ Moda sustentável é um tema ainda muito carente de referências no campo teórico e sobretudo de pesquisas para o desenvolvimento de tecnologias limpas e sustentáveis. A lógica do valor imaterial que produz desejo de consumo que se finda antes do valor tangível de funcionalidade dos produtos é um dos principais problemas, seguido das estratégias para descarte, reciclagem etc. A pesquisadora teve uma marca homônima feita a partir desses preceitos com utilização de malha de bambu, garrafa PET, reciclada e tintas não tóxicas. Tentou pesquisar o tema no mestrado em $2011 \mathrm{em} 3$ departamentos da PUC-Rio (administração, comunicação e design) e em nenhum conseguiu chegar a quem se interessasse no tema por ser considerado uma contradição do ponto de vista dos pesquisadores até então. Felizmente aos poucos surgem discussões importantes que estão mudando o cenário anterior.
} 
maneira equivocada ou de má fé por parte de empresas que banalizam os preceitos do conceito para simplesmente justificarem preços acima do mercado, como é o caso do "green wash" (lavagem verde), famoso termo que designa essa prática perversa de mercado.

Dentro do apanhado apresentado até aqui, no próximo e último item desse trabalho apresentaremos alguns projetos em andamento, frutos do investimento da pesquisadora em prol das ações potencializadoras da promoção das relações entre ensino e indústria da moda via de projetos culturais. Sendo assim, constituem experiências práticas de acordo com os caminhos propostos e, portanto, serão aqui deixadas como recomendações para sua ampliação por aqueles que de alguma forma poderão complementar esse trabalho no futuro.

O modelo de compartilhamento dos conhecimentos em torno da moda praia, de acordo com o que foi dito até aqui, se encontra fragmentado e pulverizado entre diversos canais de comunicação, principalmente em torno do Sistema S. Ele geralmente tem origem em consultorias encomendadas, é chancelado pela ABIT, e a partir de então, instituições ligadas à indústria (SENAI, FIRJAN, etc.) e ao comércio (SENAC, etc.) transformam tais informações das pesquisas em diversas publicações, como foi sintetizado no quadro "moda praia, conhecimento pulverizado" 


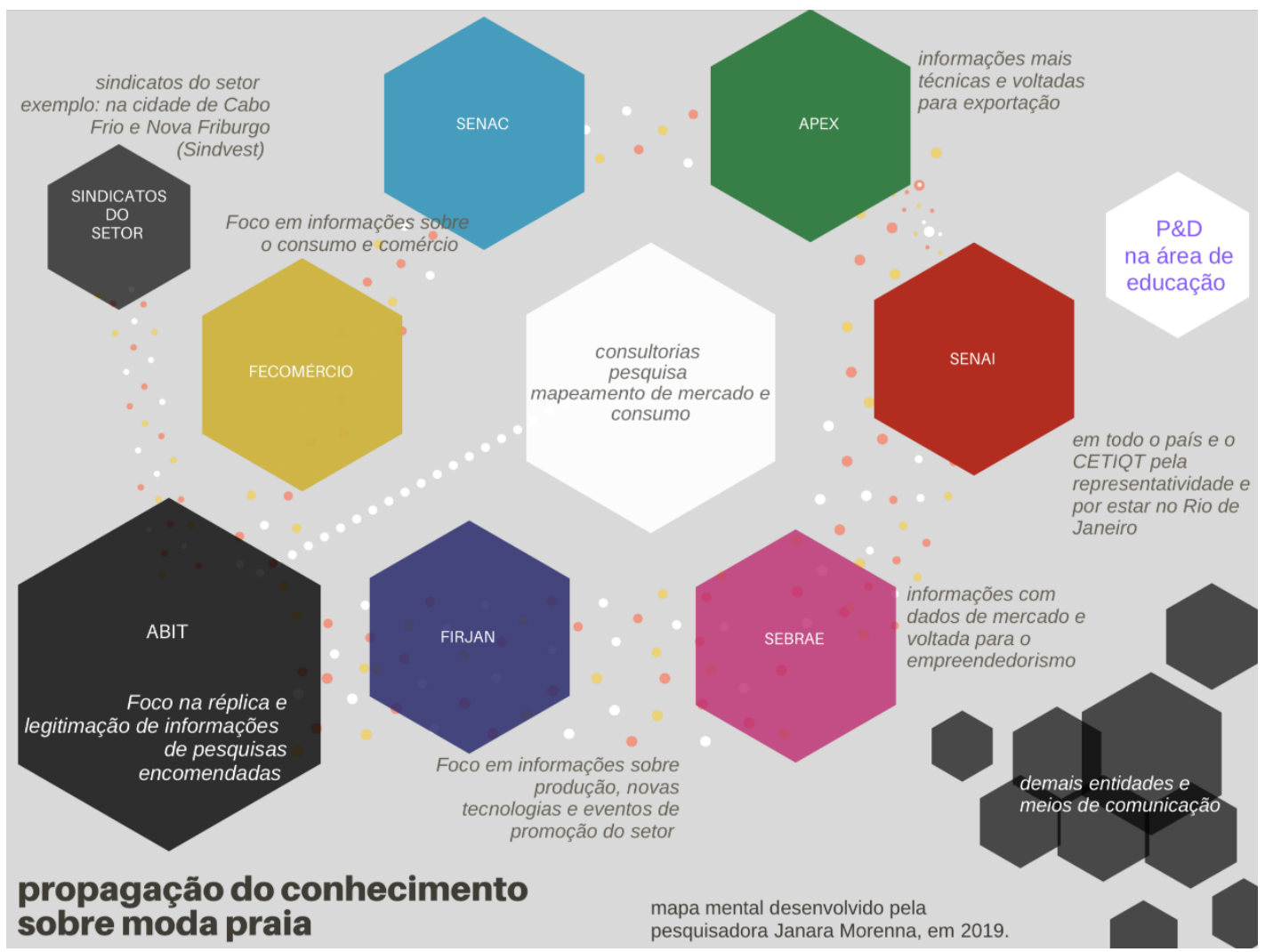

Figura 17: Moda praia, conhecimento pulverizado

Uma proposta para a sistematização do conhecimento sobre a moda praia seria a integração dos saberes produzidos na esfera da educação, P\&D em articulação com as associações da indústria, no caso a ABIT para gerar conteúdos que seriam absorvidos, de acordo com a relevância para cada setor que faz a interface entre o ensino e a indústria: SENAI, SENAC, FIRJAN, SEBRAE e demais entidades e meios de comunicação . Conforme o quadro da figura 18 "conhecimento sobre a moda praia foco na integração dos saberes": 


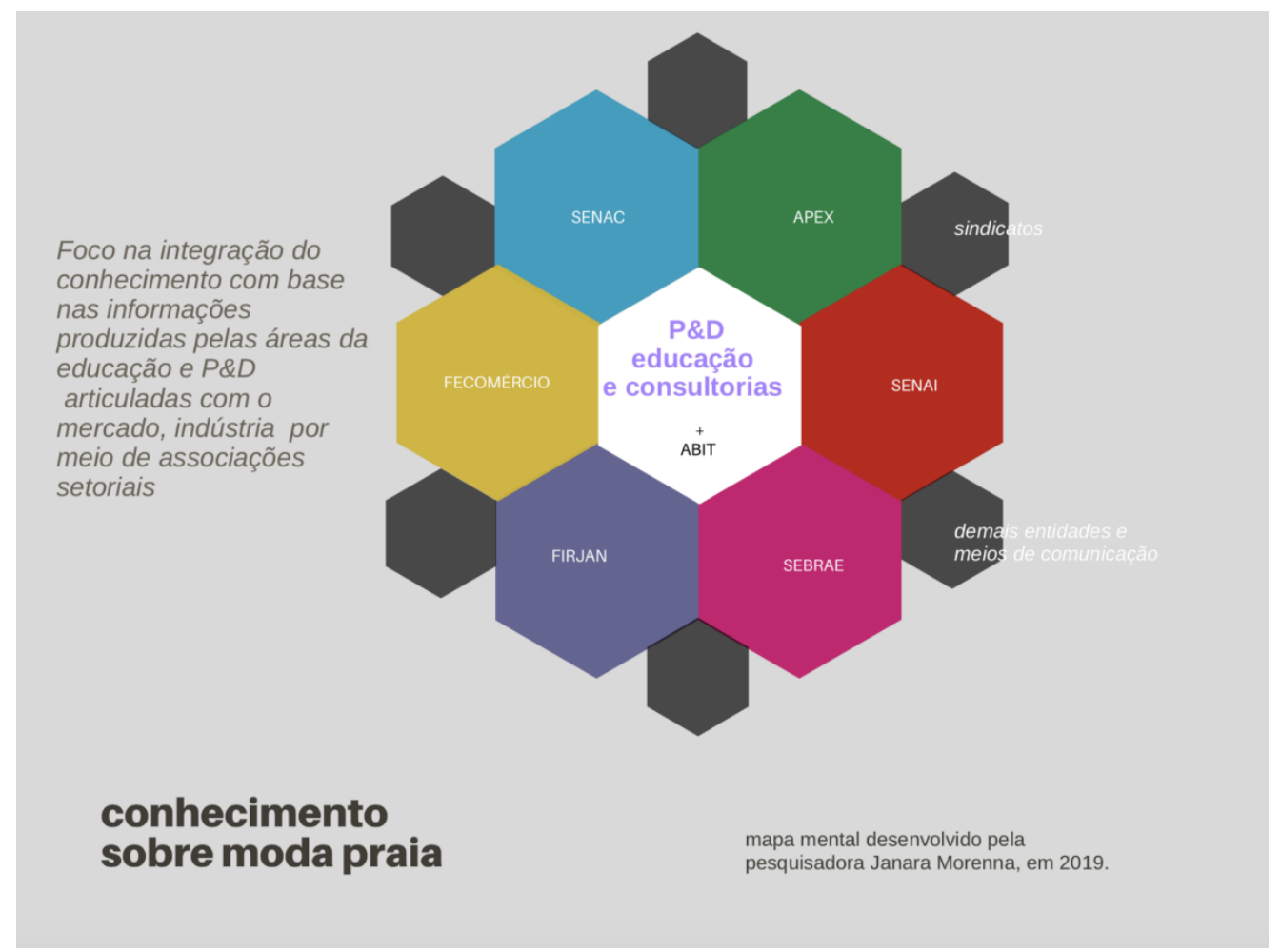

Figura 18: conhecimento sobre a moda praia foco na integração dos saberes

Por fim, a sugestão mais adequada, de acordo com os resultados do trabalho, do tamanho do mercado e representatividade da moda praia, seria a criação de um centro que concentre o conhecimento pertinente ao segmento em suas variadas extensões completares: culturais/históricas, de pesquisa, de mercado, da produção industrial, da internacionalização, do fomento ao empreendedorismo, do design (para criação, modelagem, etapas de desenvolvimento de produto). Ou seja, abarcando o universo ligado aos modos de produção da moda praia feita especialmente na cidade do Rio de Janeiro, por ser o polo difusor e maior produtor no Brasil. Tal proposta seria possível se fosse permanente, com espaço físico e virtual para consultas, inscrições. "Núcleo de promoção da moda praia nacional" 


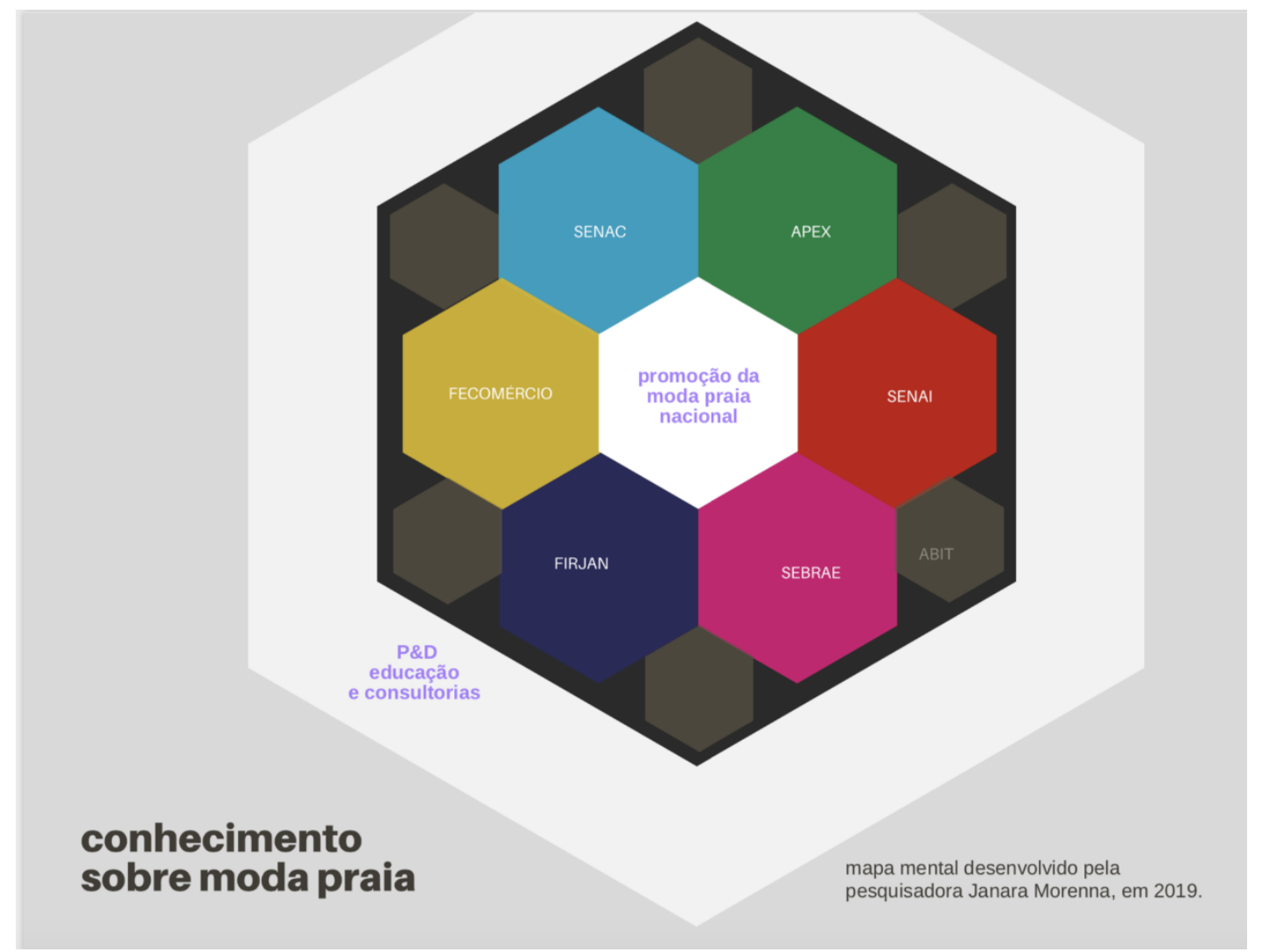

Figura 19: núcleo da moda praia com foco na promoção e propagação dos conhecimento da moda praia nacional

\section{5 \\ EXPERIMENTOS COMPARTILHADOS}

Por se tratar de um subcapítulo adicional contendo experiências de projetos propostos profissionais pela pesquisadora e que possuem relação com a tese, optou-se por falar na primeira pessoa novamente. Durante os períodos de imersão no campo tive contato com muitas pessoas interessadas no meu tema de pesquisa. Por indicação dos entrevistados como resultado da dissertação defendida em 2014, alguns projetos sobre moda praia surgiram.

O projeto intitulado "LabMuseu do biquíni carioca" desenvolvido incialmente na no Instituto Genesis, incubadora de empresas e negócios vinculado à PUC-Rio ${ }^{121}$

121 Evidências no link: https://www.reinc.org.br/empresas/lab-museu/ 
rendeu um prêmio de fomento ao empreendedorismo na área da Indústria Criativa. Em seguida, transformei a ideia em projeto de edital para a Secretaria de Cultura do Rio de Janeiro. Apesar do projeto ter sido selecionado, optei pela não realização da proposta, uma vez que foi no mesmo ano do início do doutorado. O projeto consistia em proporcionar uma experiência em torno do universo da moda praia carioca em suas extensões. A proposta seria de uma exposição “cápsula” contando a história da cultura de praia até o surgimento do mercado em uma linha do tempo com o uso de novas tecnologias.

\section{VIVA A CIDADE! \\ Edital do Produtor Cultural}

\section{CERTIFICADO DE ENQUADRAMENTO \\ Lei Municipal de Incentivo a Cultura do Rio de Janeiro}

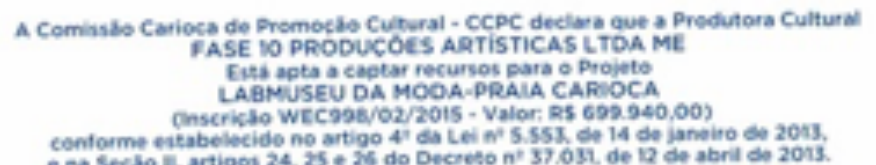

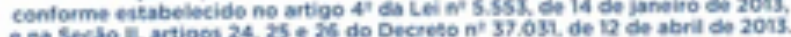

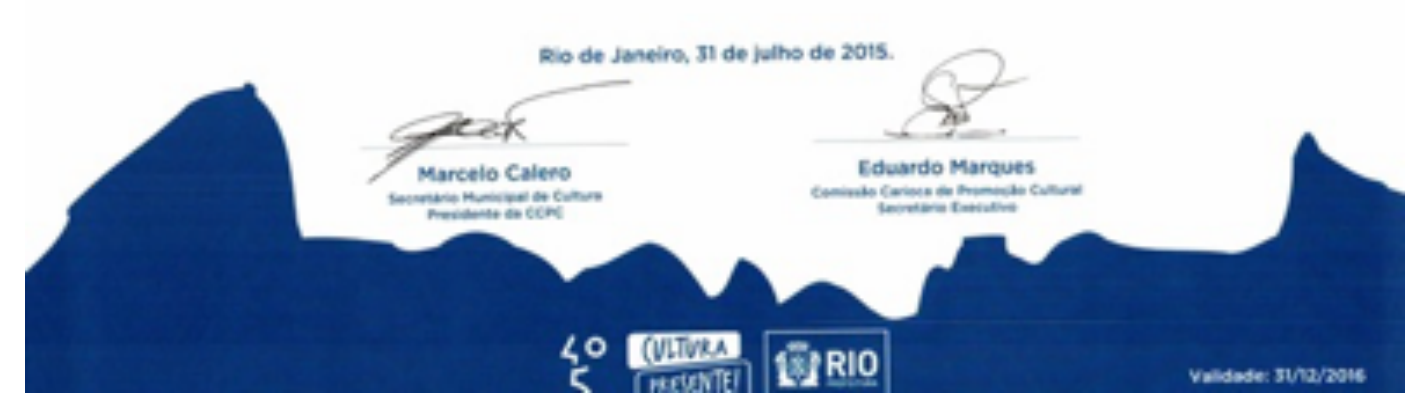

Figura 20: Certificado de aprovação realização do projeto que envolvia exposição, publicação e multimídia. Fonte: Lab Museu do biquíni carioca" acesso em 17 de março de 2019.

Em 2017, fui convidada para desenvolver pesquisas, dentre outros projetos, sob encomenda para o primeiro museu de biquíni do mundo, na Alemanha. O Bikini Art Museum $^{122}$ tem enfoque em uma historicidade que privilegia a luta das mulheres em

${ }^{122}$ Fonte: https://www.bikiniartmuseum.com/ Acesso em 19 de março de 2019. 
torno da liberdade do corpo, uma luta contada a partir dos inúmeros fatos que marcaram as mudanças no repertorio dos trajes de banho no mundo.

$\mathrm{O}$ interesse maior em ter minha contribuição se deu pelo fato do amplo levantamento histórico que fiz juntamente com a pesquisa conceitual sobre temas como norma e resistência. Nesse sentido, a moda praia foi simbólica em diversos momentos históricos. Outras colaborações se deram no aspecto criativo, no desenvolvimento de modelos pilotos de biquínis como o modelo engana mamãe ${ }^{123}$ realizado no laboratório de costura da PUC-Rio. Após confecção da peça piloto fizemos um ensaio fotografado em uma cobertura em Ipanema.

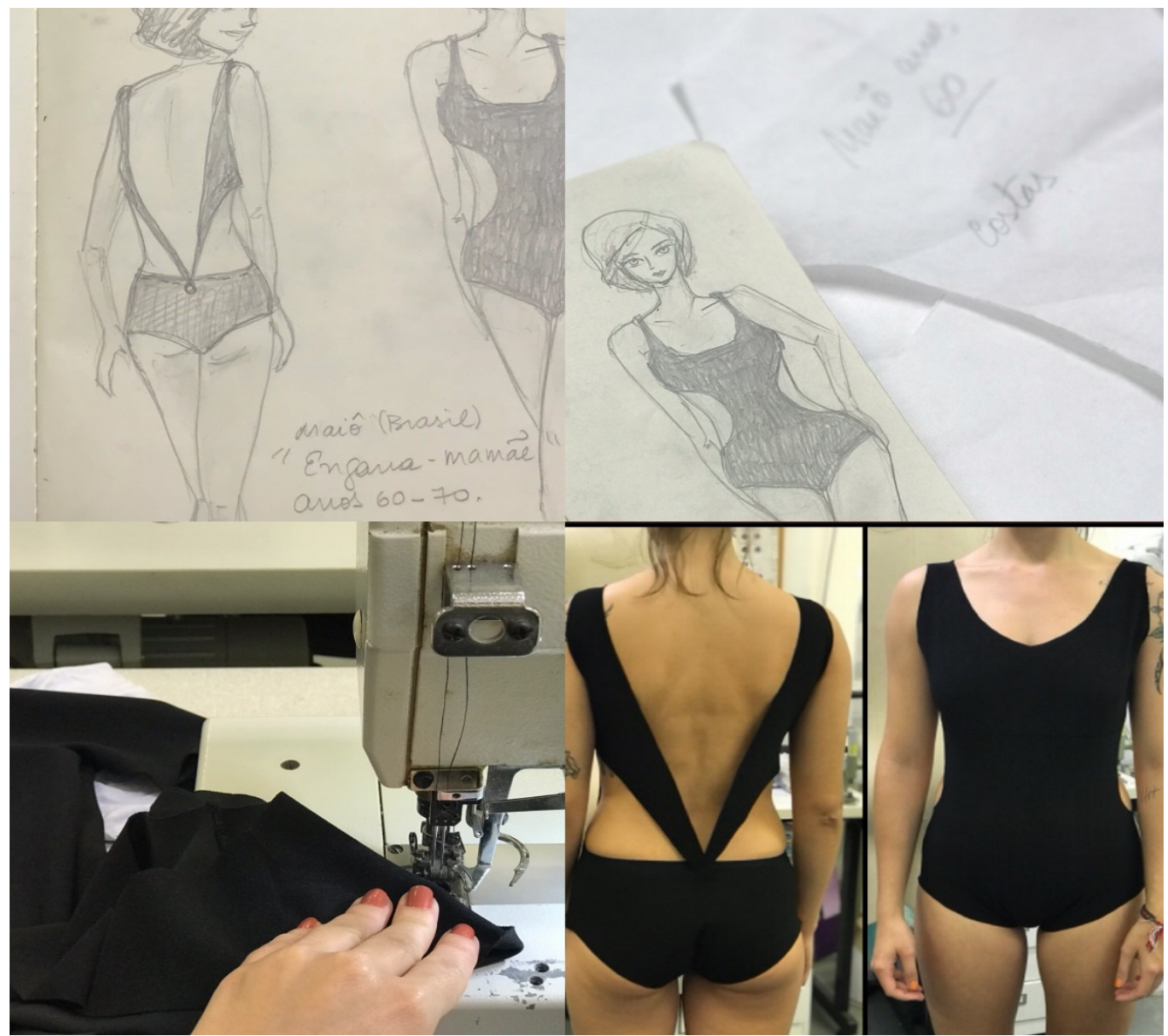

Figura 21: Processo de design, croqui, modelagem, costura, protótipo e prova. Inspiração anos 60 com material espesso e pouca elasticidade (nome desconhecido). Acervo pessoal (Janara) para Bikini Art Museum.

123 Parte do processo criativo e de desenvolvimento foi feito no laboratório de moda da PUC-Rio: modelagem, corte e costura. A produção de moda foi feita por mim com apoio da Bumbum Ipanema e em parceira com o fotógrafo Ricardo Cruz e com as modelos Aline Andrade Rosa e Giovanna Gottlieb. 


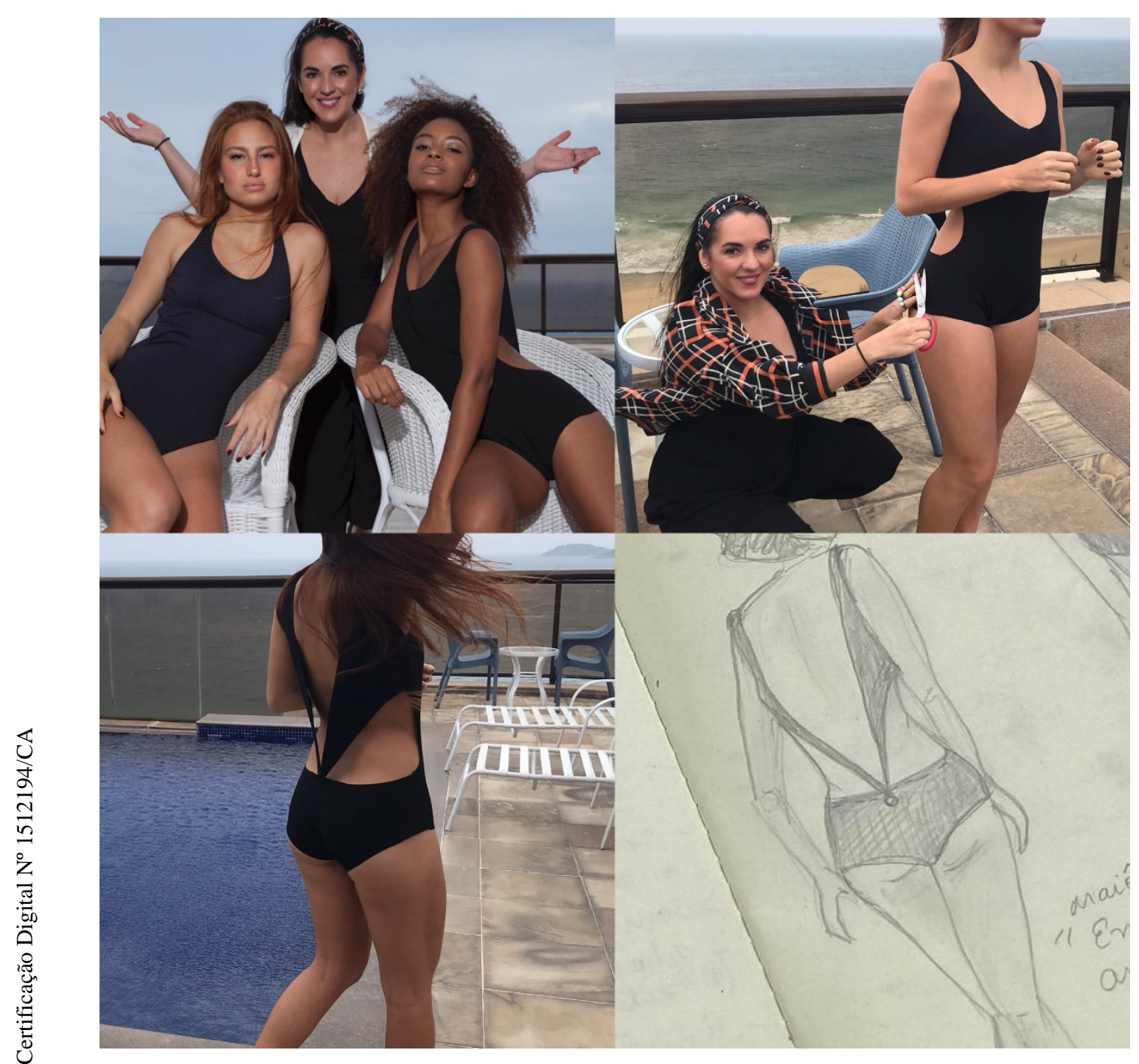

Figura 22: Etapa do projeto com produção de moda e comparação entre desenho de moda e a peça pronta. Dia da produção de moda para fotos: 5 de dezembro de 2018.

Minha contribuição mais importante para o museu começou a ser pensada no final de 2018. Como o museu terá o maior acervo de moda praia do mundo, incluindo peças usadas por ícones, artistas antigas famosas, além de fotos, peças de arte etc., despertei para o fato de que não estávamos pensando na moda praia do futuro. Sendo assim retomei um projetos iniciado no laboratório NEXT (Núcleo de Experimentação tridimensional) da PUC-Rio durante o mestrado, chamado Scan $U p^{124}$.

${ }^{124}$ O Scan Up foi desenvolvido por mim durante o curso "meu futuro negócio" realizado na escola de negócios da PUC. Apresentado no "Momento Pitch" da FIRJAN em 2014 para investidores, resultou 
A pergunta norteadora do projeto foi: como projetar a moda praia do futuro para corpos reais e pensando no meio ambiente? Partindo do pressuposto que com as tecnologias disruptivas como o escaneamento corporal e a impressão 3DP podemos fazer uma modelagem customizada para cada corpo. Também é possível experimentar novas formas de absorção de energia que possam ser utilizadas para mudar estilo, cores e percepção do modelo das peças criadas de acordo com o gosto do usuário. Dessa forma temos uma peça exclusiva, atemporal, mutante e funcional.

O objetivo é desenvolver uma peça arquitetônica vestível para um corpo específico usando tecnologias emergentes como a impressão 3DP, sensores, corte a laser, dentre outros, para transformar o tecido em uma malha mutante.

Pesquisa de referências de criação / design

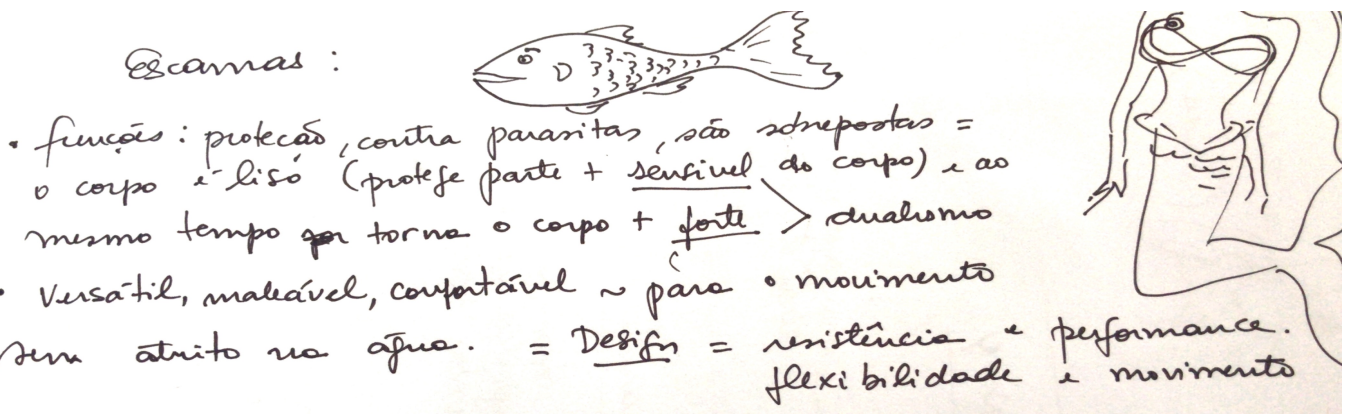

- as escamas refeneram-se

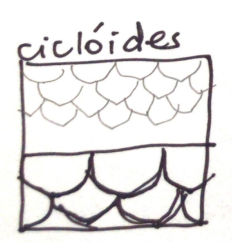

lins
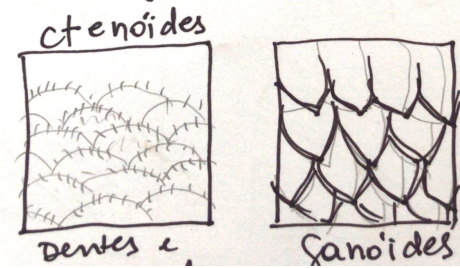

canoides

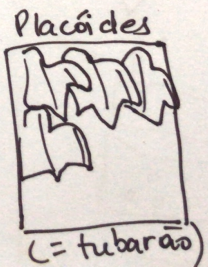

Figura 23: Referência das escamas dos peixes que ao mesmo tempo confere flexibilidade, adaptabilidade, mobilidade e força.

em um prêmio (segundo lugar). Tratava-se de uma solução para compras online com o escaneamento corporal 3D para confecção de roupas. Atualmente já é uma realidade de mercado, inclusive para o uso doméstico via aplicativo de celular, exatamente como foi pensado em 2014. 


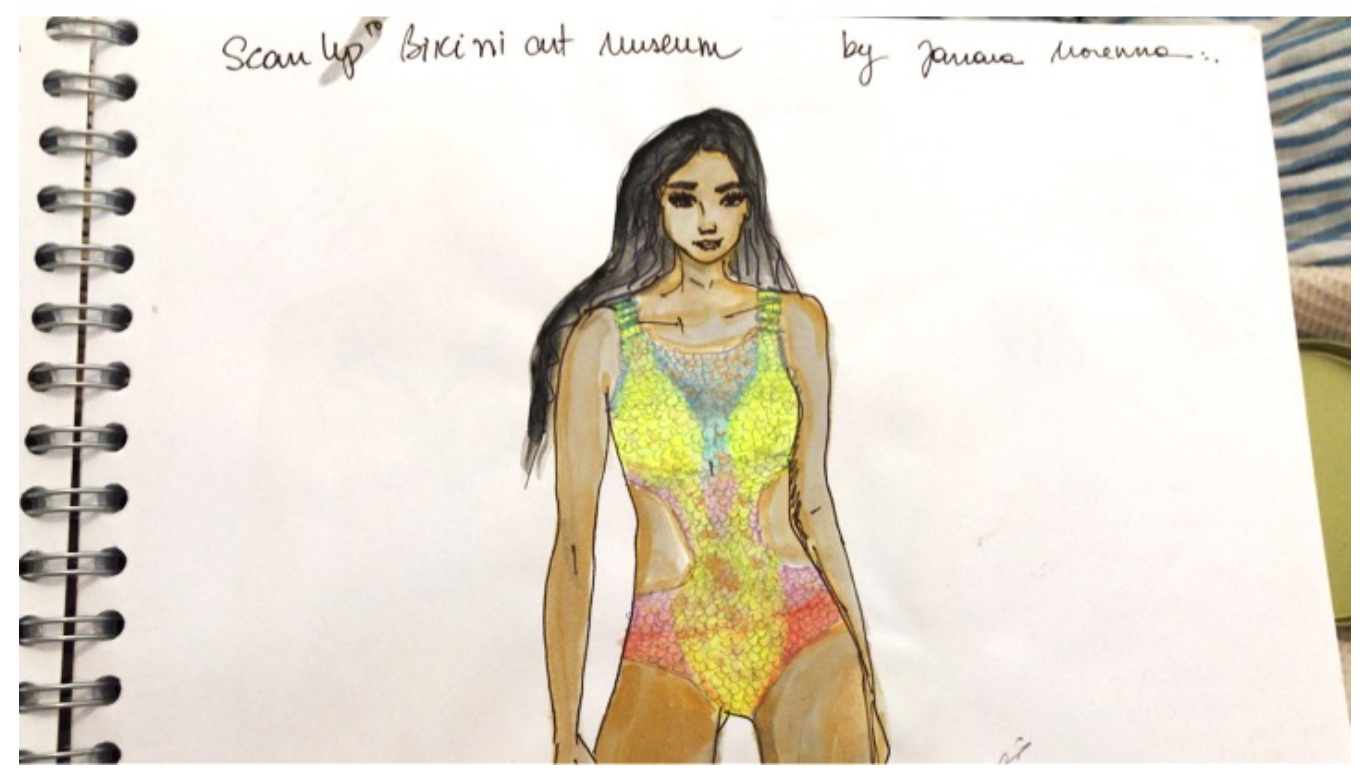

Figura 24: Modelo de maiô engana mamãe feito com escamas estilo peixe. Sugestão de materiais em impressão 3DP para escamas e malha a partir do cultivo de bactéria. Pode adicionar pigmento de Glow in the Dark ou gerar energia com mini placas solares para mudança de cores na própria peça.

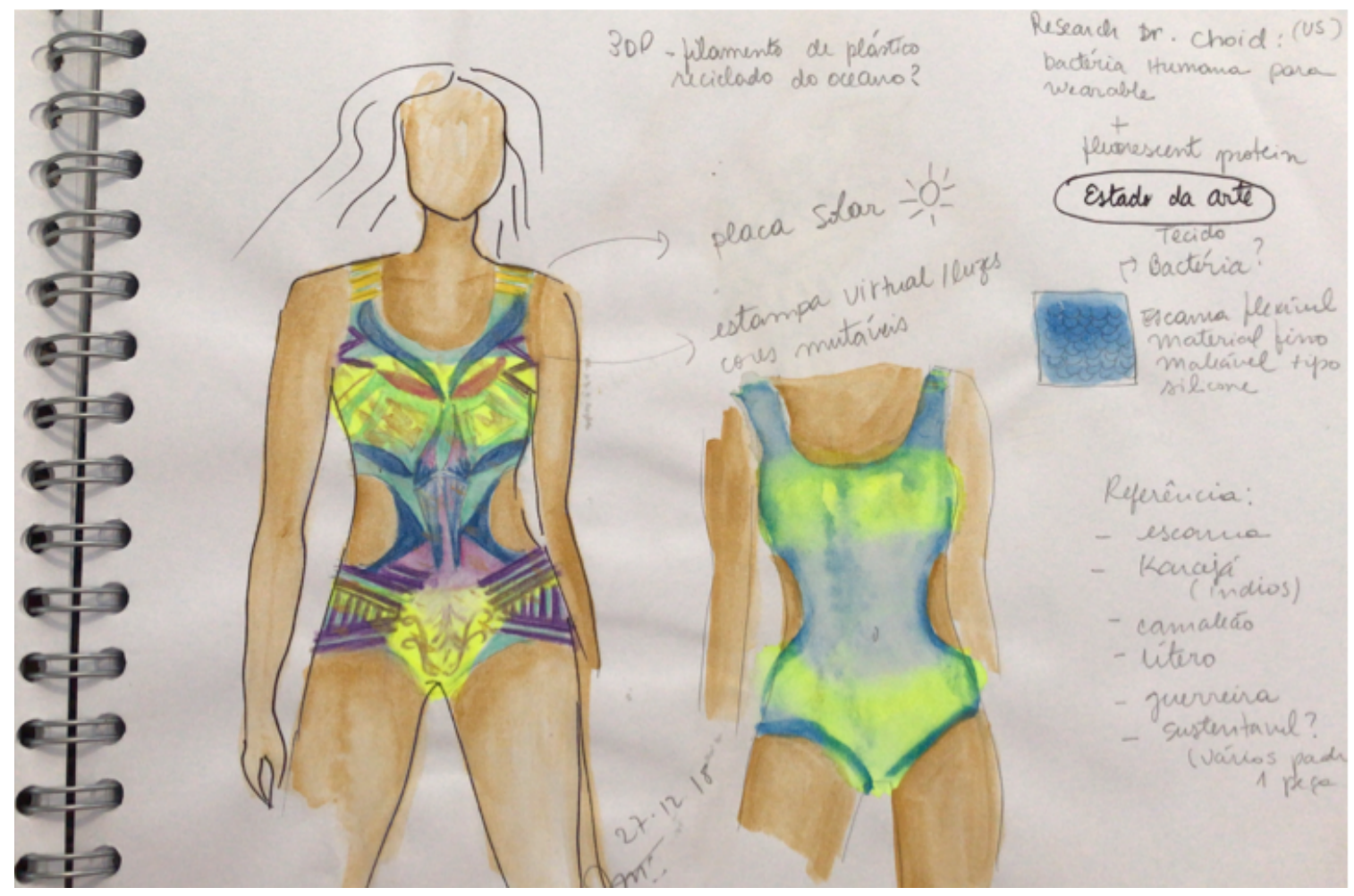

Figura 25: Perspectiva de formas que podem ser geradas a partir de fibras ópticas, eletroluminescência, bio tecido (bactérias) etc. $O$ modelo maiô engana mamãe tem a mesma base/formato. 


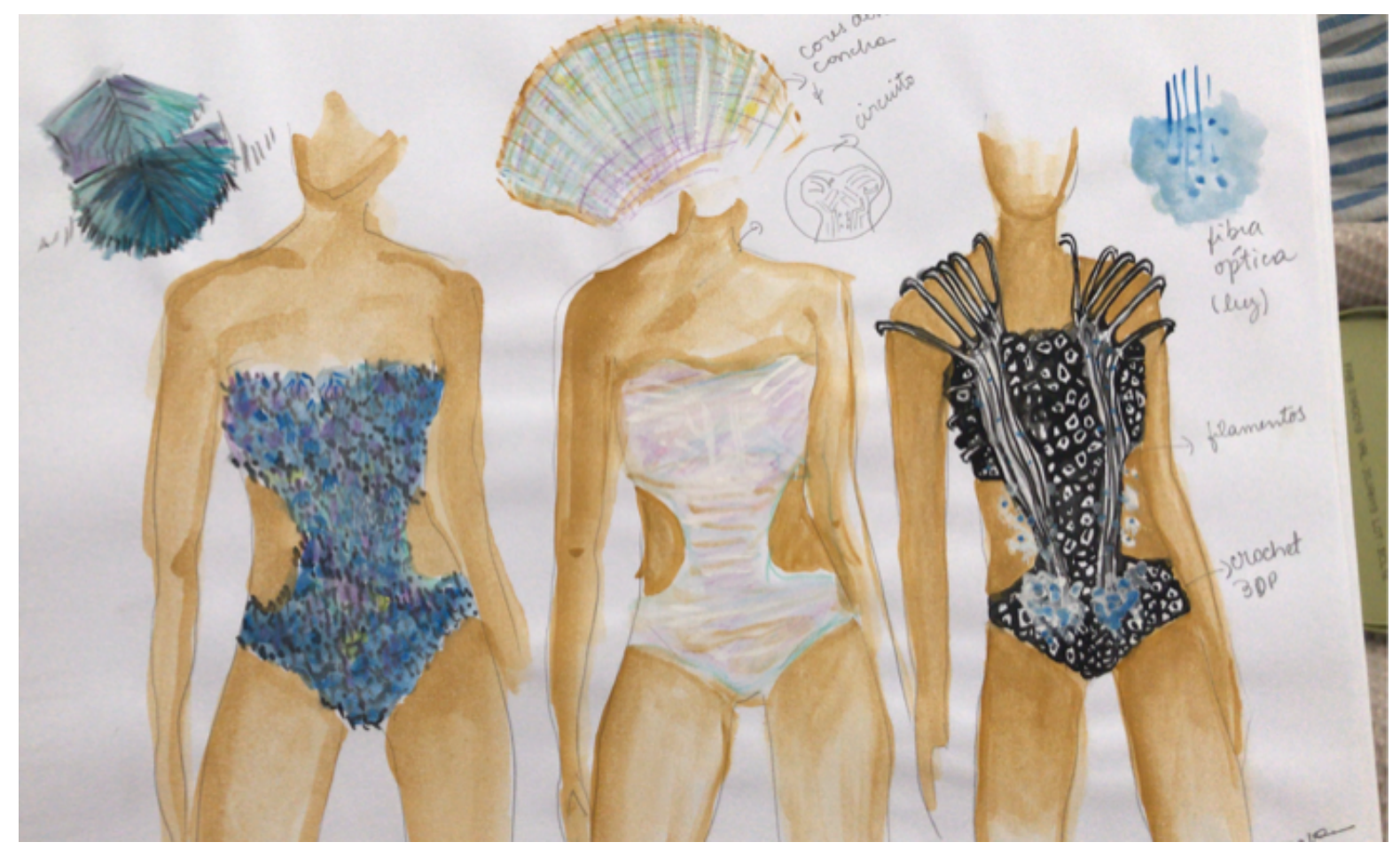

Figura 26: Perspectiva de mudança de estampas e percepção de volume no mesmo modelo. O escuro com aplicação de eletrônicos (wearable).

Outros projetos e participações que considero importantes para a divulgação do lugar simbólico da cultura de praia em suas extensões, serão registrados nos canais de comunicação que venho construindo como plataforma para indexar e compartilhar conteúdos: página de Facebook, blog, site próprio e Instagram, todos dedicados à moda praia. Lá guardei links, documentos e registros relevantes ao universo pesquisado que disponibilizo para consultas online, seguindo a lógica da democratização da informação, através do link: https://biquinicarioca.blogspot.com.br/ ("biquíni carioca"). 


\section{POST SCRIPTUM}

Recebi esta foto de minha avó, Solange Villela, quando já estava terminando a tese. Nela, minha avó posava feliz com seus “vinte e poucos anos". Ela vestia um maiô Catalina com recorte lateral e saia. A foto foi tirada pelo meu avô "Tatu" em 1947, quando eles saíram de Boa Esperança, no Sul de Minas para passarem a lua de mel no Rio de Janeiro.

Foi graças a ela, uma mulher alegre, forte e fascinante que eu pude estudar. Para minha avó, dedico em vida todos os esforços que tive o privilégio de empenhar. É gratificante quando vemos tudo ao redor se transformar pela via do exemplo, do afeto e da fé inabalável da Dona Solange.

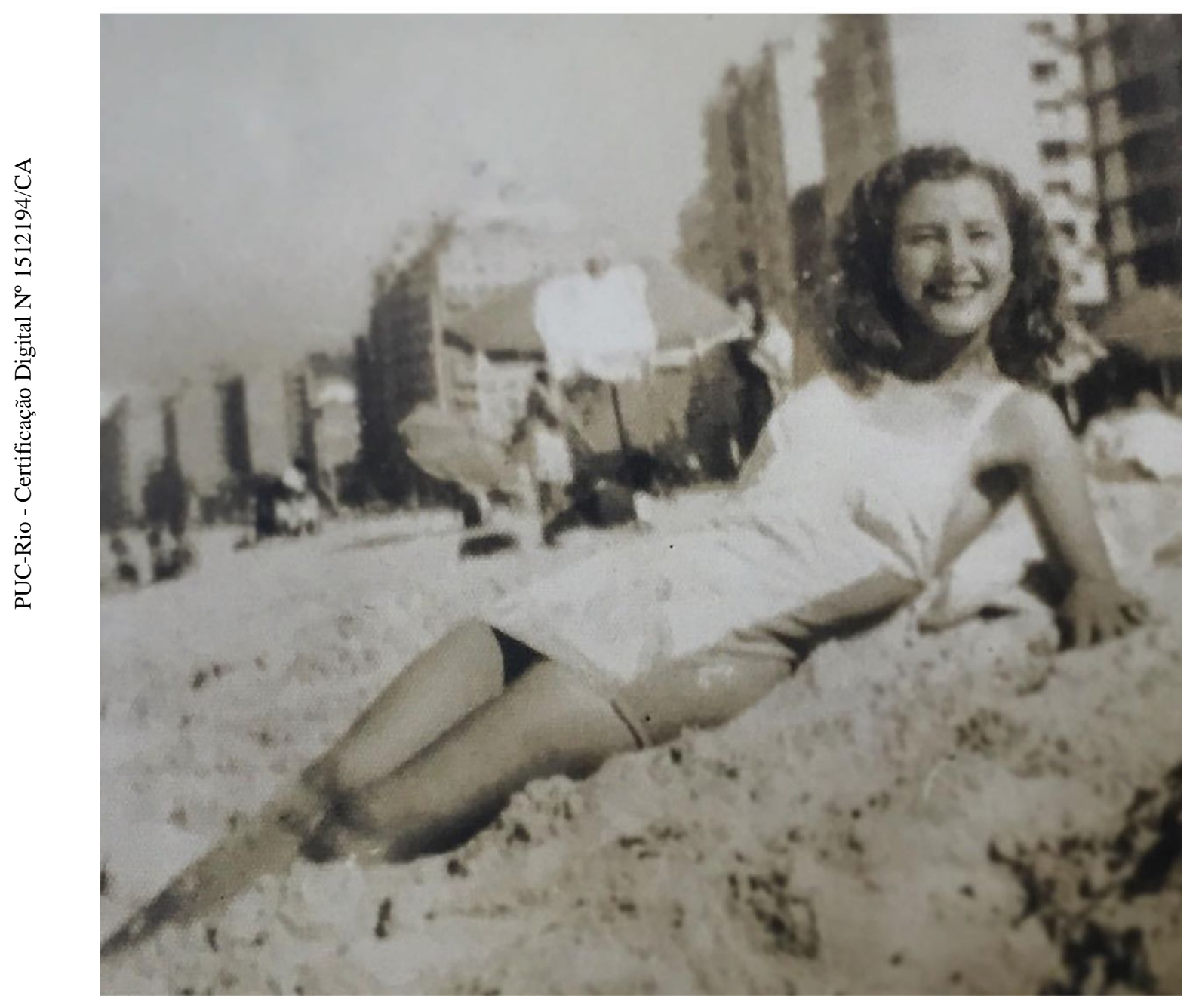

Figura 27: Foto acervo pessoal. Solange Villela na praia de Copacabana em 1947. 
REFERÊNCIAS BIBLIOGRÁFICAS

ABNT NBR 13377. Medidas do corpo humano para vestuário: padrões referenciais. Rio de Janeiro: ABNT, 1995.

ABNT, 1995. ABNT NBR 15127:2004. Corpo humano: definição de medidas. Rio de Janeiro: ABNT, 2004.

ADAMS, Jennifer. Análise da indústria de moda praia: inserção de micro e pequenas empresas no mercado internacional. USAID/Brasil: Volume 3, 2006.

BAUMAN, Z. Vida para consumo. Rio de Janeiro: Zahar, 2008.

Modernidade líquida. Rio de Janeiro: Zahar, 2001.

A cultura no mundo líquido moderno. Rio de Janeiro: Zahar, 2013.

BARTHES, Roland. O sistema da Moda. Lisboa: Edições 70, 2009.

CALANCA, D. História social da moda. São Paulo: Senac, 2002.

CASTILHO, C; GALVÃO, D. A moda do corpo o corpo da moda. São Paulo: Esfera, 2002.

CASTILHO, Kathia. Discursos da Moda: Semiótica, Design e Corpo. São Paulo: Anhembi Morumbi, 2008. 
Moda e Linguagem. 2.ed. São Paulo: Anhembi Morumbi,

2009.

CHATAIGNIER, G. História da Moda no Brasil. São Paulo: Estação das Letras e Cores, 2010.

CHATAIGNER, Gilda. Fio a Fio: Tecidos, Moda e Linguagem. São Paulo: Estação das Letras, 2010.

CIETTA, E. A economia da Moda: São Paulo, Estação das Letras e Cores, 2017.

COUTO, R. M. S. Movimento interdisciplinar de designers brasileiros em busca de educação avançada. 1997. Tese. (Doutorado em Educação) PUC-Rio, Rio de Janeiro, 1997.

COUTO, R. Reflexões sobre “A Possibilidade de uma Teoria do Design”, treze anos depois. Laboratório de Interdisciplinar de Design/Educação da PUC-Rio. Palestra Simpósio LARS, 2008.

COBRA, Marcos. Marketing e Moda. $2^{\mathrm{a}}$ ed. Sao Paulo: SENAC, 2010.

DEL PRIORI, Histórias e conversas de mulher: Planeta, 2013.

DISITZER, M. Um mergulho no Rio, 100 anos de moda e comportamento na praia carioca. Rio de Janeiro: Casa da Palavra, 2012.

FIRJAN. Indústria Criativa - mapeamento da indústria criativa no Brasil. Rio de Janeiro: SESI/SENAI Maracanã, 2012.

FOUCAULT, M. A história da sexualidade, a vontade de saber. Rio de Janeiro: Graal, 1988. 
GASPAR, B. G. Orla Carioca História e Cultura, Rio de Janeiro: Metalivros, 2004.

GOLDENBERG, M. (Org.), Nu \& Vestido. Rio de Janeiro: Record, 2002.

O corpo como capital: estudos sobre gênero, sexualidade e moda na cultura brasileira. São Paulo: Estação das Letras, 2007, pg. 176.

O corpo carioca (des)coberto In: A moda do corpo, o corpo da moda. São Paulo: Esfera, 2002, pg.111 -125.

GRASSE, M. Courps de Soleil \& Bikinis. Toulouse, França: Milan, 1997.

JOFFILY, R. Produção de Moda. Rio de Janeiro: Senac, 2011.

KOTLER, P. \& KELLER, K. L. Administração de marketing. 10a ed. São Paulo: Pearson Prentice Hall, 2009.

LAVER, James. A Roupa e a Moda. São Paulo: Companhia das Letras, 2010.

LAVILLE, C; DIONNE, J. A construção do Saber. Belo Horizonte: Saber, 1999.

LAKATOS, M. Fundamentos de metodologia científica. 7.ed. São Paulo: Atlas, 2010.

LE BRETON, D. A Sociologia do Corpo: Vozes, 2012.

LIPOVETSKY, G. O império do efêmero. São Paulo: Cia da Letras, 1997. 
Da leveza - rumo a uma civilização sem peso. São Paulo:

Amarilys, 2016.

LIPOVETSKY, G.; ROUX, E. O Luxo Eterno: Da Idade do Sagrado ao Tempo das Marcas; São Paulo: Companhia da Letras, 2008.

MANZINI, Ezio. Desenvolvimento de produtos sustentáveis: Os requisitos ambientais dos produtos industriais. São Paulo: Edusp, 2008.

MAGALHÃES, C. F. Design Estratégico, Integração e Ação do Design Industrial dentro das Empresas. Rio de Janeiro: SENAI, 1997.

MARCONI, M; LAKATOS, E. Técnicas de Pesquisa. São Paulo: Atlas, 1996.

MORIN, E. Introdução ao Pensamento Complexo. Lisboa: Instituto Piaget, 2001.

Ciência com consciência. 15 ed. Rio de Janeiro: Ed. Betrand Brasil, 2013.

NOVAES, J. Com que corpo eu vou? Rio de Janeiro: PUC-Rio, Pallas, 2010. NOVAES, J. (Org.). Corpo para que te quero? Usos, abusos e desusos. Rio de Janeiro: PUC- Rio, Appris, 2012.

PACCE, L. O biquíni made in Brazil: Rio de Janeiro: Arte Ensaio, 2016.

PALOMINO, E. Babado forte: moda, música e a noite na virada do século 21. São Paulo: Mandarim, 1999.

PIRES, D. (Org). Design de Moda, olhares diversos. São Paulo: Estação das Letras, 2010. 
PORTINARI, D. A última fronteira: repensando o corpo na contemporaneidade. São Paulo: Esfera, 2002.

PRIORI, D. Histórias e Conversas de Mulher. São Paulo: Planeta, 2013.

PIRES, Dorotéia Baduy (Org.) Design de moda - olhares diversos. São Paulo: Estação das Letras e Cores. 2010.

POLHEMUS, T. (1978). Fashion \& Anti-fashion: exploring adornment and dress from and anthropological perspective. Lexington, 2011.

ROCHA, Everardo. Comunicação, consumo e espaço urbano: novas sensibilidades nas culturas jovens. [et. al.], (orgs). Rio de Janeiro: PUC-Rio: Mauad Ed., 2006.

SCHNEIDER, A.; GRUBER, C.; Estudo comparativo entre tabelas e medidas femininas para modelagem. $7^{\circ}$ Colóquio de Moda, 2011.

SOUZA, G. M. O Espírito das Roupas. São Paulo: Companhia das Letras, 2009.

STRUNK, G. L. T. L. Como criar identidades visuais para marcas de sucesso: um guia sobre o marketing das marcas e como representar graficamente seus valores. 3. ed. Rio de Janeiro: Rio Books, 2007.

SVENDSEN, L. Moda uma filosofia. Rio de Janeiro: Zahar, 2004.

THE BRITISH COUNCIL, Brazil Fashion, 2000.

VINCENT-RICHARD, Françoise. As Espirais da Moda. Paz e Terra, 2008.

TREPTOW, Doris. Inventando Moda. Planejamento de Coleção. Brusque: D.Treptow, 2009. 
VILLAÇA, N. (Org); CASTILHO, K.(Org.). Plugados na Moda. São Paulo: Anhembi Morumbi, 2006.

VILLAÇA, N. A periferia POP na idade da mídia. São Paulo: Estação das Letras, 2011.

PERROTA, I. V. Da Garota de Ipanema ao Menino do Rio. Um estudo de signos visuais no Rio de Janeiro. Dissertação de Mestrado, PUC-Rio, orientação: Gustavo Bomfim, 2010.

REZENDE, G. C. O Brasil na Moda, novas representações de consumo e promoção da brasilidade. Departamento de Comunicação, Dissertação de Mestrado, PUC-Rio, 2010.

FREITAS, Luciana Costa. Estratégia em Design em empreendimentos em Moda, as tramas do sucesso empresarial do Design de Moda no Rio de Janeiro. PUC-Rio, Cláudio Freitas Magalhães, 2007. 


\section{ANEXO}

TERMO DE AUTORIZAÇÃO DE USO DE IMAGEM E DEPOIMENTOS

Eu

CPF , RG

depois de conhecer e entender os objetivos, procedimentos metodológicos, riscos e benefícios da pesquisa, bem como de estar ciente da necessidade do uso de minha imagem e/ou depoimento, especificados no Termo de Consentimento Livre e Esclarecido AUTORIZO, através do presente termo, a pesquisadora Janara Morena Da Silva De Oliveira da pesquisa de estudos prospectivos sobre a relação entre ensino e indústria, a realizar as fotos que se façam necessárias e/ou a colher meu depoimento sem quaisquer ônus financeiros a nenhuma das partes.

Ao mesmo tempo, libero a utilização destas fotos e/ou depoimentos para fins científicos e de estudos (livros, artigos, slides e transparências), em favor dos pesquisadores da pesquisa, acima especificados, obedecendo ao que está previsto nas Leis que resguardam os direitos das crianças e adolescentes (Estatuto da Criança e do Adolescente - ECA, Lei N. $\left.{ }^{\circ} 8.069 / 1990\right)$, dos idosos (Estatuto do Idoso, Lei $\left.\mathrm{N}^{\circ}{ }^{\circ} 10.741 / 2003\right)$ e das pessoas com deficiência (Decreto $N^{\circ} 3.298 / 1999$, alterado pelo Decreto $N^{\circ}$ 5.296/2004).

Rio de Janeiro, de de 201 
Pesquisador responsável pelo projeto

Sujeito da Pesquisa 